\title{
Pathogenesis and treatment of cytomegalovirus infections: an experimental study
}

Citation for published version (APA):

Stals, F. S. (1995). Pathogenesis and treatment of cytomegalovirus infections: an experimental study.

[Doctoral Thesis, Maastricht University]. Rijksuniversiteit Limburg. https://doi.org/10.26481/dis.19951130fs

Document status and date:

Published: 01/01/1995

DOI:

10.26481/dis.19951130fs

Document Version:

Publisher's PDF, also known as Version of record

\section{Please check the document version of this publication:}

- A submitted manuscript is the version of the article upon submission and before peer-review. There can be important differences between the submitted version and the official published version of record.

People interested in the research are advised to contact the author for the final version of the publication, or visit the DOI to the publisher's website.

- The final author version and the galley proof are versions of the publication after peer review.

- The final published version features the final layout of the paper including the volume, issue and page numbers.

Link to publication

\footnotetext{
General rights rights.

- You may freely distribute the URL identifying the publication in the public portal. please follow below link for the End User Agreement:

www.umlib.nl/taverne-license

Take down policy

If you believe that this document breaches copyright please contact us at:

repository@maastrichtuniversity.nl

providing details and we will investigate your claim.
}

Copyright and moral rights for the publications made accessible in the public portal are retained by the authors and/or other copyright owners and it is a condition of accessing publications that users recognise and abide by the legal requirements associated with these

- Users may download and print one copy of any publication from the public portal for the purpose of private study or research.

- You may not further distribute the material or use it for any profit-making activity or commercial gain

If the publication is distributed under the terms of Article $25 \mathrm{fa}$ of the Dutch Copyright Act, indicated by the "Taverne" license above, 


\section{Pathogenesis and treatment of cytomegalovirus infections: An experimental study}




\section{Pathogenesis and treatment of cytomegalovirus infections: An experimental study}

\section{Proefschrift}

ter verkrijging van de graad van doctor aan de Rijksuniversiteit Limburg te Maastricht, op gezag van de Rector Magnificus, Prof. Mr. M.J. Cohen, volgens het besluit van het College van Decanen, in het openbaar te verdedigen op donderdag 30 november 1995 om 16.00 uur

door

Franciscus Stephanus Stals

geboren te Wijnandsrade op 1 februari 1959 


\section{Promotores:}

Prof. dr. C.A. Bruggeman

Prof. dr. C.P.A. van Boven (Rijksuniwersiteit Leiden)

\section{Beoordelingscommissie:}

Prof. dr. F.C.S. Ramaekers, voorzitter

Prof. dr. M.C.E. van Dam-Mieras (Open Universiteit Heerlen)

Prof. dr. J.P. van Hooff

Prof. dr. J. van der Noordaa (Universiteit van Amsterdam)

Prof. dr. R.F.A. Zwaal 
aan mijn ouders, aan Mariētte, aan Kelly, Jeroen en Martijn 


\section{CIP-DATA KONINKLIJKE BIBLIOTHEEK, DEN HAAG}

Stals; Franciscus Stephanus

Pathogenesis and treatment of cytomegalovirus infections: Aru experimental study / Franciscus Stephanus Stals. - [S.I. : s.n.] - Ill.

Thesis Rijksuniversiteit Limburg Maastricht. - With Ref. - With summary in Dutch. ISBN 90-9008804-0

\section{NUGl 743}

Subject headings: Cytomegalovirus ; pathogenesis; treatment.

Lay out: Wil Mullers, Berg en Terblijit

Book production: Datawyse | Universitaire pers, Maastricht 


\section{Pathogenesis and treatment of cytomegalovirus infections: An experimental study}

\section{Introduction}

Cytomegalovirus (CMV) is ubiquitous in man. In otherwise healthy individuals the course of the infection remains asymptomatic and only in a minority of the patients symptomatic disease develops. In contrast, in certain groups of patients with compromised immunity, e.g. organ transplant recipients, patients with acquired immunodeficiency syndrome, and congenitally or perinatally infected neonates, disseminated CMV infections with severe symptomatic disease and a high mortality rate occur frequently.

Treatment of severe CMV disease remains difficult. The limited specificity of antiviral drugs implies that at clinically effective dosage regimen severe adverse reactions regularly occur. Furthermore, in severe interstitial lung disease, a special complication of CMV infection in patients that have received an allogeneic bone marrow transplantation, antiviral treatment is mostly ineffective.

The aims of the present study were twofold. Firstly, in an experimental animal system two different infection models were used to study the pathogenesis of generalized CMV infections and CMV-induced interstitial lung disease (ILD) in the immunocompromised host. In the generalized infection model the rats were immunosuppressed by total body $\mathrm{X}$-irradiation (TBI) and subsequently inoculated intraperitoneally with rat CMV (RCMV). The infection. parameters studied included survival, the amount of infectious virus, viral antigens and viral DNA in the internal organs and the macroscopic and histological pathology. In the second model the animals received lethal total body irradiation and replacement with allogeneic bone marrow before CMV infection. In this infection model the course of the CMV infection, graft versus host disease (GvHD) and ILD were the parameters studied. Secondly, antiviral treatment regimens including administration of antibodies, 9-(1,3-dihydroxypropoxymethyl)guanine (DHPG, ganciclovir, Cymevene(B) and the recently developed drug, (S)-1-(3-hydroxy-2-phosphonylmethoxy propylycy tosine (HPMPC), were evaluated, enploying these two infection models.

The ouline of the study is as follows. In chapter I the clinical inpact and treatment of CMV infections are discussed and the animal cytomegaloviruses and important animal models are reviewed. In chapter II the model for generalized CMV infection in the rat is described and the effect of antibody treatment on this process is studied. For this purpose, hyperimmune serum was administered intravenously. The effect on survival, the presence of viral DNA and viral antigens and the pathologic changes in the spleen, liver, kidney and lungs were recorded. Antibody treatment was studied in relation to the degree of immunosuppression and the infective dose administered. 
In Chapter III the recently developed drug HPMPC was compared to the currently available drug DHPG with respect to the effective dose, the duration of treatment and the start of antiviral treatment. Studied parameters were survival, the amount of infectious virus in the internal organs and the extend of histopathologic changes.

In chapter IV an infection model for ILD is described. Animals received a high dose of TBI, followed by allogeneic bone marrow transplantation (BMT $x$ ). After subsequent infection with RCMV the development of ILD was studied. In this model the therapeutic effects of HPMPC and DHPG on RCMV expression and the histopathology in the lung were studied.

In chapter $V$ the effect of HIS and DHPG treatment on RCMV infection and ILD was studied either alone or as a combination. Both the antiviral activity and the effect on the local inflammatory reaction in the lung were studied.

In Chapter VI a modified allogeneic BMTx model was used to study the pathogenesis of ILD in relation to $\mathrm{CMV}$ infection and GvHD. In these experiments rats received an allogeneic lung transplant prior to TBI, RCMV infection and allogeneic BMTx. The experiments provided the possibility to study ILD in rats with one allogeneic and one syngeneic lung with respect to the bone marrow. The presence of interstitial histopathological changes, CMV antigens and infectious $\mathrm{CMV}$, and the spleen weights and the presence of perivascular infiltrates was determined in order to study parameters for ILD, infection and GvHD, respectively.

In chapter VII the results and conclusions of this thesis are summarized and discussed. 


\section{Contents}

Chapter I

Clinical impact and treatment of CMV infections

Chapter II

An animal model for therapeutic intervention studies of CMV infection in the immunocompromised host

\section{Chapter III}

Comparative activity of (S)-1-(3-hydroxy-2-phosphonymethoxypropyl)cytosine and 9-(1,3-dihydroxy-2-propoxymethyl)guanine against rat cytomegalovirus infection in vitro and in vivo

Chapter IV

Rat cytomegalovirus-induced pneumonitis after allogeneic bone marrow transplantation: effective treatment with (S)-1-(3-hydroxy-2-phosphonylpropoxymethyl)cytosine

\section{Chapter $\mathbf{V}$}

Generalized cytomegalovirus infection and CMV-induced pneumonitis in the rat: Combined effect of 9-(1,3-dihydroxy-2-propoxymethyl)guanine and specific antibody treatment

\section{Chapter VI}

Cytomegalovirus induces interstitial lung disease in allogeneic bone marrow transplant recipient rats independent of acute graft wersus host response

Chapter VII

Summary and general discussion

Samenvatting en algemene discussie

List of publications

Dankwoord

Curriculum vitae 


\section{List of abbreviations}

a.-TAP a-transactivating protein

ACV 9-(2-hydroxyethoxymethyl)guanine, acielovir

AD169 human CMV strain (adenoid isolation 169)

ADCC antibody-dependent cell mediated cytotoxicity

AIDS acquired immunodeficiency syndrome

AP

$\mathrm{BAL}$

activated protein

BME

$B M T$

BMTX

bronchoal veolar lavage

$\mathrm{BN}$

$\mathrm{BPP}$

CMV

$\mathrm{CNS}$

$\mathrm{DHHO}$

DNA

E

basal medium Eagle

bone marrow transplant

bone marrow transplantation

$\mathrm{EC}_{50}$

$\mathrm{G}+\mathrm{C}$

gP

$\mathrm{gA}$

$g B$

Brown Norway

basic phosphoprotein

cytomegallovirus

central nervous system

9-(1,3-dihydroxypropoxymethyl)guanine, ganciclovir, Cymevene(B) desoxynucleic acid

early

effective concentration at $50 \%$

guamine and cytosine

glycoprotein

glycoprotein A

gclII

glycoprotein B

GCR

$\mathrm{gH}$

glycoprotein cIII (see gH)

$\mathrm{gL}$

G-protein coupled receptors

$\mathrm{gM}$

glycoprotein $\mathrm{H}$

glycoprotein L

GPCMV

Gy

glycoprotein $M$

$\mathrm{HCMV}$

guinea pig cytomegalovirus

Gray

HEF

human cytomegalovirus:

HIS

human embryonal fibroblast

HMWP high molecular weight protein

HPMPC (S)-1-(3-hydroxy-2-phosphonylmethoxypropyl)cytosine

$1 \mathrm{C}_{50}$

ICP

IE inhibitory concentration of cell growth at $50 \%$ infected cell protein

IFN- $\gamma$ interferon- $\gamma$

ILD interstitial lung disease

IMP intermembrane protein 


$\begin{array}{ll}\text { IP } & \text { interstitial pneumonia; pneumonitis } \\ \text { i.p. } & \text { intraperitoneal } \\ \text { i.v. } & \text { intravenously } \\ \text { kDa } & \text { kilo Dalton } \\ \text { kb } & \text { kilo base pairs } \\ \text { L } & \text { late } \\ \text { LMP } & \text { lower matrix protein } \\ \text { MCMV } & \text { mouse cytomegalovirus } \\ \text { MCP } & \text { minor capsid protein } \\ \text { MCP } & \text { major capsid protein } \\ \text { MDBP } & \text { major DNA binding protein } \\ \text { MHC-1 } & \text { major histocompatibility complex-1 } \\ \text { NCS } & \text { new-born calf serum } \\ \text { NK-cells } & \text { natural killer cells } \\ \text { ORF } & \text { open reading frame } \\ \text { PCR } & \text { polymerase chain reaction } \\ \text { PFA } & \text { phosphono formic acid, foscarnet, Foscaviri } \\ \text { PK } & \text { phosphokinase } \\ \text { PMEA } & 9 \text {-(2-phosphonylmethoxyethyl)adenine } \\ \text { PMEDAP } & \text { 9-(2-phosphonylmethoxyethyl)-2,6-diaminopurine } \\ \text { PML } & \text { progressive multifocal leucencephalopathy } \\ \text { PMN } & \text { polymorphonuclear cells } \\ \text { Pp } & \text { phosphoprotein } \\ \text { p.i. } & \text { post infection } \\ \text { RCMV } & \text { rat cytomegalovirus } \\ \text { REF } & \text { rat embryonal fibroblast } \\ \text { SCP } & \text { smallest capsid protein } \\ \text { TCR- } \gamma & \text { T-cell receptor } \gamma \text { chains } \\ \text { TBI } & \text { total body irradiation } \\ \text { TNF- } \alpha & \text { tumour necrosis factor- } \alpha \\ \text { Tx } & \text { transplantation } \\ \text { UL } & \text { unique long sequence } \\ \text { UMP } & \text { upper matrix protein } \\ \text { US } & \text { unique short sequence } \\ & \end{array}$




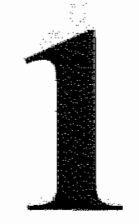

Clinical impact and treatment of CMV infections 


\section{Historical perspectives}

Cytomegalowirus (CMV) is named after the histopathologic changes in infected cells, characterized by an increase in cell size and intranuclear inclusions. In 1904 cytomegalic-like disease was described for the first time and at that time it was thought to be of protozoan origin $(154,245)$, (figure 1). In 1925 a relation between the disease and members of the herpes virus group including Varicella was suggested $(123,189)$. This suggestion was later on supported by experimental evidence, indicating the relation between virus infection and the presence of intranuclear inclusions in cells. In 1950 "generalized cytomegalic inclusion disease" was described as a clinical entity occurring in infants (314). In the period 1956-1957 the human cytomegalowirus (HCMV) was isolated independently by 3 different research groups. The group of Smith isolated a HCMV from uterine cell cultures that showed cytopathogenic effect upon inoculation with salivary gland tissue from an infant; the isolated strain is described as the Smith strain (277). The group of Weller isolated the Davis strain from skin-muscle cells from a three-month-old infant. The Kerr strain was isolated from the urine of another infant by the same group (304). The ADI 69 strain was described by Rowe who isolated this CMV strain from adenoidal tissue (250). The latter strain is now widely used for studies on CMV infections in vitro.

\section{Viral characteristics}

Cytomegalovirus is a member of the herpes viridae family. It is characterized by the presence of double stranded DNA and an envelope. CMV is classified in the subfamily of B-herpesviridae. This classification is based on the following biologic properties: the restriction to the specific hosts, a long reproduction cycle, slow infection of cell cultures and enlargement of infected cells. Cytomegaloviruses are further characterized by the persistence of the virus in a latent state in cells of secretory glands, lymphoreticular tissue, kidneys and other tissues. The subfamily of the B-herpesviridae contains the genera cytomegalovirus (human cytomegalovirus) and muromegalovirus (nurine cytomegalovirus) (109).

The HCMV genome is a relatively large linear, double stranded DNA molecule with a relative molecular mass of $150-155 \cdot 10^{6} \mathrm{kDa}$ and a density of $1.716-1.717 \mathrm{~g} / \mathrm{cm}^{3}$. The $\mathrm{G}+\mathrm{C}$ content of the DNA is $57.2 \%(58,77,117)$. It is composed of a long and a short segment, each linked by terminal repeat elements, which permit isomerization (163). The genome of AD169 has a length of 229,354 bp and shows approximately 200 open reading frames (58) making CMV a large and complex virus. HCMV contains a relatively large number of related genes, or gene families, which tend to be clustered as homogeneous blocks of open reading frames that mosily encode for glycoproteins $(59,307)$. Interestingly, it also contains homologues of at least three cellular genes coding for respectively: class I major histocompatibility (MHC-1) antigens (CMV UL83), T-cell receptor $\gamma$ chains (TCR- $\gamma$; CMV UL20), and G-coupled receptor protein (GCR; CMV UL33 and US27), (69). All these proteins are cell surface receptor proteins with as yet unknown functions in the process of infection. 


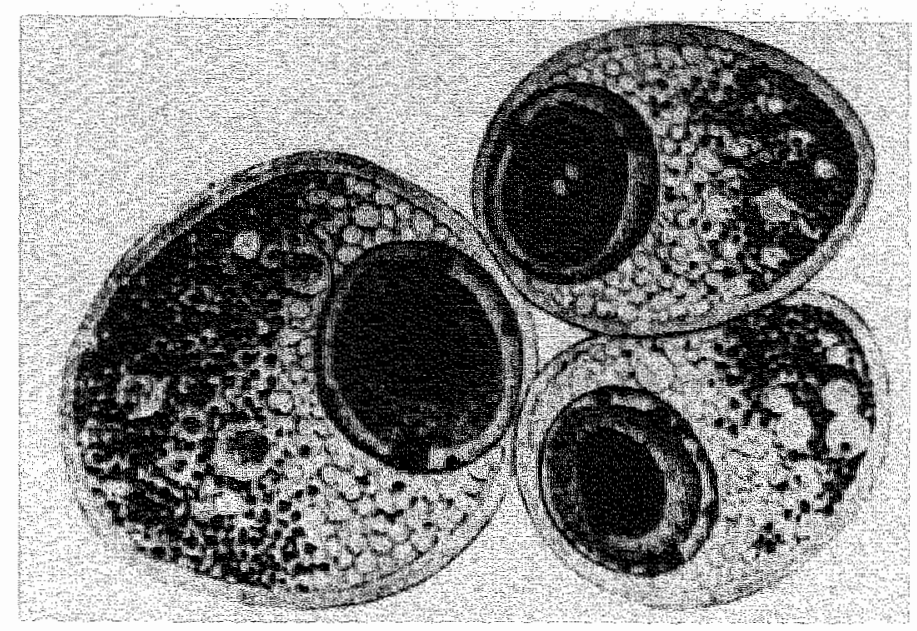

Figure 1. "Protozoan"-like cells observed in a leut ic fetus (Minchener Medizinische Wochenschrift, 1904).

The first step of the infection cycle is attachment of the virus to the cell surface. After heparan sulphate mediated adsorption of the virus to the cell $(159,216)$ a pH-independent fusion of the virus with the cell membrane takes place $(67,161)$ followed by uncoating of the virus. Subsequently, the DNA is transported to the nucleus, where expression and replication of the genome takes place. During lytic replication DNA synthesis initiates from a single origin, which is localized near the centre of the UL segment $(3,137)$. After imitiation, three main phases of expression can be recognized, designated as the immediate early (IE), early (B) and late (L) phase, respectively. Roughly, the IE and $\mathbb{E}$ proteins precede viral DNA synthesis, whereas the production of $\mathrm{L}$ proteins takes place predominantly after DNA synthesis (120). After assembly the virion is enveloped through the nuclear membrame of the cell $(52)$ and liberated from the cell surface (225).

Generally, CMV encoded proteins can be divided into two groups based on their presence or absence in the virion. The first group consists of protens that are important for vial replication, but form no structural part of the extracellular infectious virus particle. These "nonstructural" proteins, that have an important role in the replication cycle of the virus in the cell, are extensively reviewed elsewhere (175).

The second group consists of proteins, assembled into the virus particle. These so called "structural" proteins are listed in table 1 and depicted in figure 2.

The nucleocaps»d contains four proteins. The major nucleocapsid protein encoded by UL 86 is the main protein in the nucleocapsid (58). The nucleocapsid further contains the protein ppUL80A(AP), the minor capsid protein pUL46(mCP) located on the outline of the cytoplas mic capsid, and the smallest capsid protein (SCP) (58). 
Table I. Nomenclature of human cytomegalovirus structural proteins.

\begin{tabular}{|c|c|c|c|c|c|}
\hline $\begin{array}{l}\text { Name } \\
\text { (UL (16) }\end{array}$ & Location. & $\begin{array}{l}\text { ORF } \\
\text { designations }\end{array}$ & $\begin{array}{c}\text { Lutterature } \\
\text { - }\end{array}$ & $\begin{array}{l}\text { Protem } \\
\text { MW(kDa) }\end{array}$ & $\begin{array}{l}\text { Reference } \\
\text { number }\end{array}$ \\
\hline DUL86(MCB) & apside & $4 L 86$ & $\begin{array}{l}\text { ICP4, MCP } \\
\mathrm{pp} / 50,153 \mathrm{k}\end{array}$ & $p\lfloor 55$ & $(58,119)$ \\
\hline PpULBOA(AP) & capsid & ULBOA & $\mathrm{AP}, \mathrm{p} 36, \mathrm{p} 38, \mathrm{p} 35$ & $\mathrm{p} 37$ & $(119)$ \\
\hline $\mathrm{pUL} 46(\mathrm{mCP})$ & capsid: & ULA6 & $\mathrm{mCP}$ & p34 & $(119)$ \\
\hline DULA & teguminent & UL48 & HMWP, pp $200, p_{216}$ & $\mathrm{p} 212$ & \\
\hline PpUL32(BPP) & tegumierit & UL 32 & $\mathrm{BPP}^{3}, \mathrm{p} 149$ & $\mathrm{p} 150$ & $(22,31,248)$ \\
\hline$p p \cup L \& 2(\alpha-\mathbb{T} A P)$ & tegument: & UL 82 & $\mathrm{UMP}, 72 \mathrm{kDa}, \mathrm{p} 74$ & $\mathrm{p} 71$ & $(248)$ \\
\hline$p p \cup L S 3(P K)$ & tegument & UE 83 & $\begin{array}{l}\text { LCF27, LMP, pp } 65 \\
\text { pp66, gp64, p69, } \\
\text { p68, PK68 }\end{array}$ & p 65 & $(176,224,228)$ \\
\hline ppUL6S(PK) & tegument & UL65 & & p67 & \\
\hline ppuL99 & tegument & UL99 & $\mathrm{pp} 28, \mathrm{p} 25, \mathrm{p} 32$ & $\mathrm{p} 28$ & $(179,204)$ \\
\hline pLL 56 & unknown & UL 56 & & $\mathrm{p} 96$ & \\
\hline ppUL99A & unknown & UL99A & & p58 & \\
\hline gpUL4 & envelope & ULA & gp48 & p48 & \\
\hline gpUL $55(\mathrm{gB})$ & envelope & $10 L 55$ & $\begin{array}{l}\mathrm{gA}, \mathrm{gp} 58, \mathrm{gB} \\
\mathrm{gp} 55-116, \mathrm{gcl}\end{array}$ & pl30/93/55 & $(225,226)$ \\
\hline gpUL75(gH) & envelope & UL.75 & $\begin{array}{l}\text { p86, gp } 86, \mathrm{gH} \\
\text { gellI }\end{array}$ & p86 & $(160-161,239)$ \\
\hline gpUL $100(\mathrm{M})$ & enwelope & UL 100 & IMP & $p 45$ & \\
\hline gpUL\|15(gL) & unknown & UL1IS & $\mathrm{gL}$ & p32 & \\
\hline gPULI8 & unknown & ULI8 & MHC-1 homologue & p68 & \\
\hline gpUS10 & unknown & US 10 & & $\mathrm{p} 22$ & \\
\hline gpUS11 & unknown & USH 1 & & $\mathrm{p} 32$ & \\
\hline
\end{tabular}

AP, activated protein; $\mathrm{BPP}$, basic phosphoprotein; gP, glycoprotein; g $\mathrm{A}$, glycoprotein $\mathrm{A} ; \mathrm{gB}$, glycoprotein $\mathrm{B}$; gcll, glycoprotein cll: gH, glycoprotein H; gL, glycoprotein L; gM, glycoprotein M; HMWP, hight molecular weight protein; ICP, infected cell protein; IMP, intermembrane protein; $\mathrm{kDa}$, kiloDalton; mCP, minor capsid protein; LMP, lower matrix protein; MCP, major capsid protein; MHC-1, major histacompatibility complex-1; ORF, open tading tame; $\mathbb{P}^{2} \mathrm{~K}$, phosphokinase; $p_{*}$ phosphoprote in; $\alpha$-TAP, $\alpha$-transactivating protein; UL, unique tong siguence; UMP, upper matrixprotein; US, unique short serquence.

The tegument, the viral matrix located between nucleocapsid and the membrane consists of at least six proteins. The ppUL99 protein is located on the surface of cytoplasmic nucleocapsids $(179,204)$. The lower phosphorylated matrix protein ppUL83(PK), the upper matrix protein ppUL $82(\alpha-T A P)$ and the basic phosphoprotein ppUL32(BPP) are the most abundantly transcribed proteins. Except pUL48, a high molecular weight protein all tegument proteins serve in vitro as phosphate acceptors for virion-associated protein kinase (248). The ppUL32(BPP) is modified by O-linked $\mathrm{N}$-glucosamine residues after phosphorylation (22, $31,119,248)$, which makes it highly immunogenic $(232,258)$.

The envelope of HCMV contains two important glycoproteins, the guL55(gB), also designated as glycoprotein $\mathrm{B}(\mathrm{gB})$, and the gpUL 75(gH), designated as glycoprotein $\mathrm{H}(\mathrm{gH})$. One 


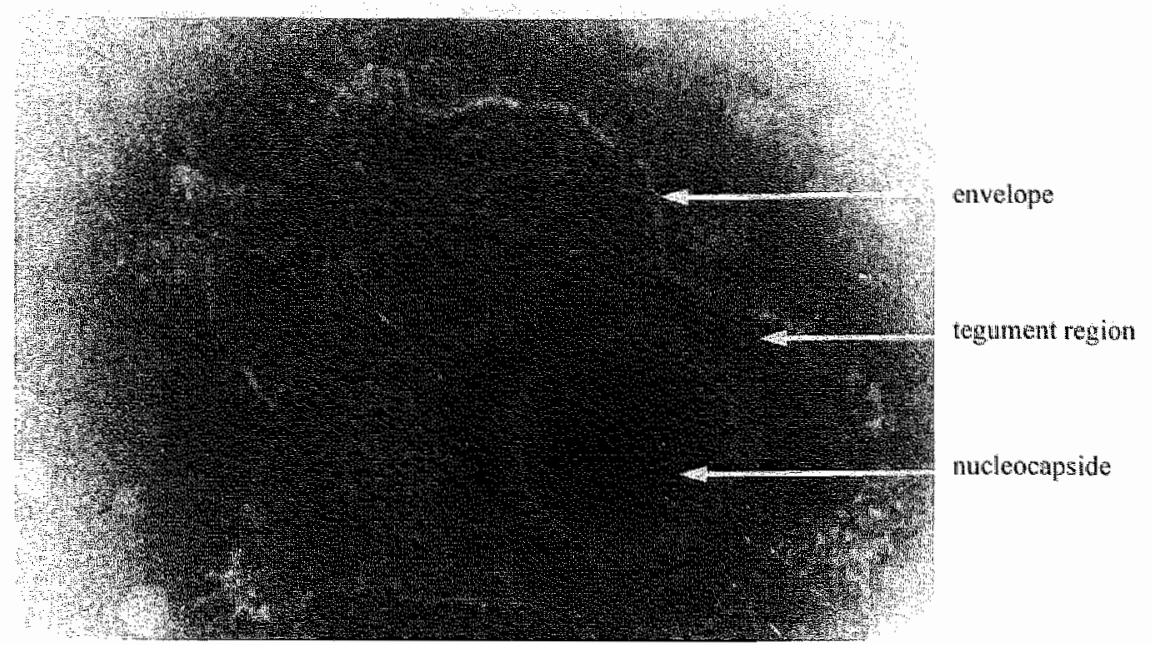

Figure 2. Electronic microscopic appearance of cytomegalovirus.

of the most important glycoproteins that elicit humoral immunity is gB. It is produced during the whole infection cycle of the cell and it is formed by proteolytic cleavage of a $150 \mathrm{kDa}$ precursor protein $(225,226)$. The extracellular portion of $\mathrm{gB}$ contains four immunodominant domains, two in the amino-terminal part and two in the carboxy-terminal part. Another envelope protein is gpUL 75 , i.e. a $86 \mathrm{kDa} \mathrm{L}$ protein composed as a $80 \mathrm{kDa}$ single gene product to which mannose-linked oligosaccharides are added (239). This glycoprotein is involved in the virus-cell fusion process $(160,161)$. The other proteins are listed in table 1 .

\section{The immunological control of HCMV}

It is generally accepted that the immunological contro》 of herpes virus infections including infections with CMV is mainly achieved by T-cell response. CD8 T-cells have cytolytic activity on infected cells and recognize viral antigens presented by the major histocompatibility class I (MHC-I) molecules. CD4 T-cells have regulatory functions and recognize viral antigens presented by $\mathrm{MHC}-11$ molecules.

The cellular control is supported by the humoral immunologic response. Antibodies can act independently of cellular immunity, for example by neutralizing free virus particles, and in corroboration with the cellular response, like in the case of antibody dependent cytotoxicity. During primary CMV infection of an immunocompetent host the immune system prevents overt disease by confining and teminating acute virus replication, but it fails to clear the viral genome. CMV by evolving into a state of latency evades eradication and remains ready to cause a recurrent infection whenever the immune control fails. Consequently, an enduring 
Trabe 2. Clincal impact of CMV infection.

\begin{tabular}{|c|c|c|}
\hline $\begin{array}{l}\text { Senting of } \\
\text { infection }\end{array}$ & $\begin{array}{l}\text { Principle sources } \\
\text { of yirus }\end{array}$ & Symptoms \\
\hline Congenital & Maternal, primary & $\begin{array}{l}\text { Hearing loss, deafness, mental retardation, } \\
\text { cerebral palsy, visual impairment. }\end{array}$ \\
\hline $\begin{array}{l}\text { Transiplantation } \\
\text { kidney } \\
\text { heart Iung } \\
\text { liver } \\
\text { marrow }\end{array}$ & $\begin{array}{l}\text { Craft, } \\
\text { reachlination } \\
\text { blood products }\end{array}$ & $\begin{array}{l}\text { Disseminated infection, pneumonia, } \\
\text { bepatitis; impaired graft function, } \\
\text { opportunistic infections, } \\
\text { (retinitis, colitis) }\end{array}$ \\
\hline ADS pattents & reactivation & $\begin{array}{l}\text { progression to AIDS, } \\
\text { retinitis, colitis and } \\
\text { wasting, pneumonia }\end{array}$ \\
\hline $\begin{array}{l}\text { Premature, } \\
\text { very low } \\
\text { birth weight }\end{array}$ & blood products & $\begin{array}{l}\text { disseminated infection, pulmonary deterioration, } \\
\text { hepatitis, death, hearing loss }\end{array}$ \\
\hline
\end{tabular}

control of CMV infection is only accomplished in the presence of a competent immune system. The most important, though indirect, evidence that control of CMV infection is predominantly achieved by cellular immunity is the high frequency of generalized CMV infections and symptomatic disease in patients with impaired T-cell immunity, such as transplant recipients and AlDS patients. Under these circumstances the role of the humoral immune response is of increasing importance.

The relative importance of acquired immunity as opposed to natural immunity in control of CMV infection can be deduced from experiments in mice with severe combined immunodeficiency disease (SCID) mice. (305). As opposed to their immunocompetent counterparts, SCID mice succumb to CMV disease with high virus titres in the internal organs. Additional studies indicate that particularly MHC-I restricted cytotoxic T-cells are protective against mouse cytomegalovirus (MCMV) infections (241). The spread of infection can be prevented by MHC-I restricted inmunity as soon as the virus enters the cell before the first gene products are formed (246). The predominant cytotoxic $T$-cell target is the major $\mathrm{IE}$ gene product (28, 240). Helper T-cells play an additional role in the response to CMV since selective depletion of helper T-cells results in higher virus titres in organs and an delayed antibody response (102).

Since depletion of natural killer (NK) cells in the SCID mice accelerated the development of lethal disease, the natural immunity represented by NK-cells has a supportive protective action (305). Depletion of $\mathrm{NK}$-cells lowered the resistance of immunosuppressed mice to a lethal MCMV challenge and increased virus titres in the internal organs (263). 
Antibody response to $\mathrm{CMV}$ is thought to be important for the elimination of free virus particles. Although the contribution of antibody response to the clearance of $\mathrm{CMV}$-infected cells seems to be only supportive, the activity of antibodies might be of importance during circumstances of impaired $T$-cell immunity. The humoral response during primary CMV infection starts with the production of IgM class antibodies, which declines after weeks to months. The $\operatorname{IgM}$ response is followed by the production of $\operatorname{lgG}$ class antibodies which persist for lifetime. In addition, secretory IgA antibodies in saliva and low level serum IgA antibodies are formed during the acute phase of infection (146).

One of the most important envelope-sited glycoproteins that elicit humoral immunity is $\mathrm{gpUL} 55(\mathrm{gB})$. The carboxy-terminal region of the extramembranous portion of $\mathrm{gB}$ contains regions that react with neutralizing and non-neutralizing antibodies (298). The intramembranous domain of the carboxy-terminus is less immunogenic than the extramembranous portion of $\mathrm{gB}(227)$. The amino-terminal half of guL $55(\mathrm{gB})$ also seems to be a target of neutralizing antibodies in a substantial proportion of seropositive individuals after recurrent infection and sometimes after primary infection $(190,227)$. The occurrence of antibodies to the glycoprotein gpUL 75(gH) occurs less frequently then antibody formation to gpUL55 $(\mathrm{gB})$. Antibodies against the gpUL $75(\mathrm{gH})$ protein exhibit complement independent neutralizing activity and are strain specific (293). The major capsid protein pUL86(MCP) has a limited antigenicity $(153,255)$. ppUL83(PK) is one of the most highly immunogenic protein recognized (176, $224,228)$ and is preferentially reactive for IgM class antibodies (153). From this protein four immunodominant regions are recognized representing over $50 \%$ of the reading frame $(31$, 231). Also, the ppUL99 protein is highly immunogenic especially for IgG antibodies but not for IgM antibodies $(177,178,204)$. In general the membrane proteins of the virion elicit antibodies neutralizing free virus particles and the proteins of the inner part of the virion elicit antibodies, which co-operate with the cellular immunity to recognize CMV-infected cells. Cytokines are important for intercellular communication and are supposed to play a role in the control of CMV infection. For instance, production of interferon (IFN)- $\gamma$ and tumour necrosis factor (TNF)- $\alpha$ by $\mathrm{CMV}$-infected cells protects surrounding cells against CMV infection (87). In addition, CMV induces the production of interleukin 1 (11-1) in many cell types. Interestingly, monocytes express II.-1. after CMV challenge, but only when these cells are differentiated (85). Also, TNF-a can be induced by CMV in these cells (85), showing that CMV can elicit a spectrum of cytokines.

\section{Epidemiology and clinical significance of CMV}

Early seroepiclemiological studies demonstrated a high prevalence of antibodies against CMV $(50-80 \%)$ in the general population $(158,287)$. The prevalence depends on the socio-economic state and age. In developing countries a relatively high seroprevalence is seen in early childhood and in early adulthood $(54,170,287)$ with a preponderance of females over males $(158,306)$. In western countries the seroprevalence increases steadily with about $10 \%$ every decade resulting in a prevalence of $80 \%$ in the elderly. 
Healthy adults occasionally are the source of infectious virus to spread CMV by indirect contact, but children in early childhood are the predominant source. The virus is shed from the urinary and the respiratory tract $(158,167)$. Children therefore spread the virus easily in day care centres (222) and infect their parents (2). Perinatal infections are acquired during birth, by breast feeding and by mother infant contact $(51,286)$. Adults at high risk for $\mathrm{CMV}$ infection are patients visiting sexual-transmitted-disease clinics, promiscuous homosexuals and AIDS patients, indicaling transmission by sexual contact $(55,56,125)$. Another mode of transmission occurs by transfusion of blood or blood products $(108,247)$. Since the virus is associated with leucocytes these infections can be prevented by removal of the leucocytes (121). Finally, the virus can also be transmitted by solid organ and bone marrow transplantations $(143,311)$.

CMV is an important human pathogen mainly due to its ability to cause severe disease during periods of impaired immunity. The variety of symptoms displayed depends largely on the specific immunological impaiment of the host (table 2), (221). In the immunocompetent host CMV infection remains generally asymptomatic and only occasionally a mononucleosis-like illness develops. It is, however, a leading cause of congenital infection. CMV infections are a major threat to patients who receive immunosuppressive therapy and symptomatic CMV infections are encountered in patients receiving chemotherapy, in patients with severe burns and in patients with congenital immunodeficiencies. More recently, CMV infection proved to be the cause of severe and life threatening infections in patients with acquired immunodeficiency syndrome (AIDS).

\section{Infection of immunocompetent patients}

In the majority of cases acquired CMV infection runs an asymptomatic course and only relatively few patients suffer from a mononucleosis-like syndrome. This syndrome, defined as a febrile illness for a period of approximately 10 days with mononucleosis and lymphocytosis with over $90 \%$ atypical lymphocytes, is in the majority $(70-80 \%)$ of the cases associated with Estein-Barr virus. In less than $10 \%$ of the cases this clinical picture is caused by a CMV infection (165). CMV mononucleosis is a rare finding in early childhood and most patients are 15 years or older. CMV mononucleosis characteristically presents itself with a mild hepatitis, that can be distinguished from Epstein-Barr virus associated mononucleosis by the absence of pharyngitis. Occasionally, complications, such as pneunonia, myocarditis, meningoencephatitis and hepatosplenomegaly, do occur $(53,166,288)$.

\section{Congenital and perinatal infections}

Cytomegalic inclusion disease (CID) of the foetus is almost exclusively a result of primary infection of the mother during pregnancy. About 7-10\% of the congenitally CMV-infected children develop acute symptoms, such as petechia (76\%), jaundice (67\%), hepatosplenomegaly $(60 \%)$, microcephaly $(49 \%)$, lethargy/hypotonia $(27 \%)$, poor suck (20\%) and seizures $(7 \%)$. Half of the infected new-borns is small for gestational age and $30 \%$ is born 
prematurely $(223,230)$. The long-term sequelae, mainly due to damage of the central nervous system (289), results in an impaired development, mental retardation, neuromuscular abnormalities, deafness and visual impairment. Although the incidence of CID is low, the morbidity and mortality rates are high, and the long-term prognosis of these clinical cases is poor as compared to the asymptomatic patients $(90 \%$ versus $15 \%)(64,223,230,309)$.

In earlier days, severe primary CMV infections were encountered in neonates and preterm infants after blood transfusion. In these immunologic immature hosts a severe disseminated disease with hepatosplenomegaly, respiratory deterioration, pneumonia and thrombocytopenia occurred with a high mortality rate $(40-50 \%),(16,319)$.

\section{Infection of immunocompromised patients}

\section{AIDS patients}

The prevalence of CMV inlections among adult HIV-seropositive individuals is nearly $100 \%$. Excretion of infectious virus is common, and generalized infection with viraemia occurs frequently at low (CD4 $4^{-}$) T-cell numbers (259). CMV infection may contribute to morbidity and mortality in HIV-infected individuals in several ways.

First, AIDS patients may suffer from generalized CMV infection. The most frequently occurring symptoms associated with CMV infection in these patients are retinitis, gastrointestinal ulcers, wasting and CMV pneumonia. The pneumonia in these patients has a ligh fatality rate and is often complicated by other opportunistic pathogens, in particular Preumocystis carinii (259). An inflammatory response is absent in the lungs of the majority of CMV-infected AIDS patients (15). This is in contrast to CMV pneumonia in bone marrow transplant recipients.

Second, there is increasing evidence that CMV infection affects the course of other opportunistic infections, for example $\mathrm{JC}$ virus infection. $\mathrm{CMV}$ seems to induce the replication. The JC virus is associated with progressive multifocal leucencephalopathy (PML) in AIDS patients and in this way CMV could indirectly contribute to the development of PML (140).

Finally, CMV may alter the course of HIV infection itself. The in vitro findings that CMV transactivates the long terminal repeat element of HIV supports the suggestion that also in vivo the interaction at molecular and cellular level may accelerate the progression to AUDS in HIV-infected patients $(73,302)$. Clinical CMV infection can accelerate the development of AIDS (115,236).

\section{Organ transplant recipients}

CMV infections occur frequently in organ transplant recipients resulting in increased morbidity and mortality, and impaired graft survival. The manifestation of CMV infection among transplant recipients is dependent on several variables, such as the severity of immune suppression, the graft match and the CMV serostatus of the recipient. The symptoms are more serious after primary than after secondary infections. Symptoms tend also to be more severe 


\section{Chapter 1}

in heart and liver recipients than in kidney transplant recipients, in whom immunosuppressive regimens are less rigorous (252). The onset of clinical symptoms and abnormal laboratory findings coincides with the start of viral shedding or viraemia and occurs generally in the first three months after transplantation $(252,289)$. Symptoms attributed to CMV infections are listed in table 2. Impaired graft function has also been associated with CMV infection although the pathophysiologic process has not yet been elucidated $(15,308)$. The development of CMV-related interstitial lung disease (ILD) is known to be associated with a CMV seropositive donor and recipient, and with the administered immunosuppressive regimen (230). CMV infection in organ recipients can occur by reactivation of latent virus from either the recipient or from a latently infected organ graft. Previously CMV-infected recipients can be reinfected with a new strain from the donor organ (64).

\section{Bone unarrow recipients}

CMV infections play an important role in allogenic bone marrow transplant (BMT) recipients. Especially in these patients, CMV infections occur frequently with severe morbidity and a final mortality percentage of $18 \%$ (146). The most important pathogenic feature of CMV infection described in these patients is the development of ILD (251). The outcome of ILD is poor despite antiviral treatment (13).

CMV infections are associated with graft versus host disease (GvHD) in allogeneic BMT recipients $(131,252)$. The virus has also a general immunosuppressive effect in these patients. One example is the myelosuppression by CMV in this patient group, which is possibly related to a lack of colony-simulating factor production (308).

\section{Pathogenesis of CMV disease}

\section{General considerations}

A frequent and interesting unresolved problem is the identity of cytomegalic cells. They are frequently associated with ductal epithelium and have thus been assumed to represent epithelial cells. It is paradoxal that fibroblasts in cell culture are more susceptible for $\mathrm{CMV}$ than epithelial cells. Also endothelial cells are frequently infected in vivo, but in vitro these cells are not very susceptible to CMV (127). Many highly differentiated cells may be abortively infected. The reason for these striking differences between what is observed in tissues and in cell culture is unknown (146).

Another interesting observation is the variety of symptoms observed in different patient groups. In AIDS patients retinitis and gastrointestinal ulcers are frequently observed, but in transplant recipients, these symptoms are rare. In allogeneic bone marrow transplant recipients interstitial lung disease is most prominent, but in congenitally infected patients hepatitis, splentis and cerebral infections are the most important problems (146). It is a challenge to find a common denominator for the expression of disease in different organs of these patient groups. 


\section{Non-pulmonary CMV infections}

\section{Vascular involvement}

Two kinds of vascular involvement are recognized, being long-term wascular lesions, associated with asymptomatic (latent) CMV infection, and vasculitis, associated with acute CMV infections.

Evidence for the first kind of vascular involvement is provided by the group of Melnick, who described the relation between CMV infection and the presence of atherosclerotic lesions (202). The association between CMV infection and atherosclerosis is also described by our group $(41,142)$. Damage at the vascular wall seems to enhance this process (284). Moreover, it is described that in transplant recipients CMV -induced intravascular wall inflammation can contribute to allograft arteriosclerosis (169).

The second kind of vascular involvement is described in patients with impaired imnunity. In neonates vasculitis and thrombocytopenia are symptoms of generalized congental infection. CMV-infected cells from endothelial origin were shown to be present in the peripheral blood of organ transplant recipients during acute CMV infection $(126,127)$. In these patients vascular inflammatory disease has been described $(48,72)$. Vascular pathology seems also to be involved in the complications described below and the question raises which role vascular pathology plays in the pathogenesis of ILD.

\section{Chorioretinitis and central nervous system disease}

Ocular disease due to CMV infection occurs only in immunocompromised patients and is especially common in AIDS patients, in whom 5-10\% of the patients have clinical evidence of retinitis (27). It begins at one site, ultimately affecting both eyes. Ophthalmologic examination of the retina reveals large, creamy to yellowish white granular areas with perivascular exudate and haemorrhages (cottage cheese with catsup). The lesions often start in the peripheral region and extend to the macula. Retinal detachment is at frequent complication $(141,320)$.

Central nerwous system (CNS) infection by CMV occurs primarily in new-borns, as a result of congenital infection. In immunocompromised patients CNS involvemertit occurs frequently. About $30 \%$ of the patients with AIDS has proven central nervous system infection by CMV (157). The clinical significance is, however, not clear. The majority of the cases may directly result of neural invasion with HIV, but CMV infection can probably induce subacute encephalitis in some of the patients with AIDS (139). Fever, altered mental states, personality changes, difficulty in concentrating, headaches, confusion, and somnolence are frequent symptoms. Brain biopsies show perivascular cuffing and periventricular necrosis, giant cells, intranuclear and intracytoplasmatic inclusions in cytomegalic cells $(139,147)$. A distinct clinical presentation of ventriculomencephalitis emerges with encephalitis, cranial nerve involvement, nystagmus, cerebrospinal fluid pleocytosis, hypoglycorthagia, and progressive 


\section{Chapter I}

ventriculomegally (157). Furthermore, progressive polyradicullopathy $(164,208)$ and multifocal neuropathy has been described with periyascular infiltration and necrotizing arteritis (249).

\section{Gastrointestinal involvement}

Gastrointestinal symptoms associated with CMV infection occur frequently in patients with AIDS (83); they also occur in solid organ and bone marrow recipients (7, 46). CMV colitis is characterized by diarrhoea, abdominal pain, weight loss, anorexia and fever, and it can be complicated by colonic perforation, haemorrhage and even peritonitis. Histologically, CMV infection is detectable in the gastrointestinal tract from the mouth to the rectum in columnar epithelial cells, endothelial cells, myocytes, and fibroblasts. As a result CMV infection of the gastrointestinal tract may display symptoms of oesophagitis, gastritis, complicated by ulcers and bleeding $(46,83)$.

\section{CMV-induced ILD}

Only few immunocompetent patients with primary CMV infections develop symptomatic disease characterized by a mononucleosis syndrome. In about $6 \%$ of the patients with CMV mononucleosis a mild self-limited ILD is observed. In contrast, in immunocompromised patients ILD is a major cause of morbidity and mortality. In about $50 \%$ of the neonates with cytomegalic inclusion disease and in $16-32 \%$ of the organ transplant recipients with acute CMV infection severe ILD develops. Especially, in bone marrow transplant recipients ILD occurs with a high frequency and with mortality up to $80 \%$ (25I). In AIDS patients the role of CMV in lung pathology remains unclear (251).

In transplant recipients symptomatic disease develops predominantly in those patients in whom CMV can be detected in samples of blood and bronchoalveolar lavage (BAL) fluid shortly after transplantation $(49,97)$. The absence of detectable CMV or viral DNA in blood and BAL samples strongly correlates with survival (218). The risk factors for the development of CMV-associated ILD are primarily those factors, which either affect the incidence ofCMV infection, such as age, CMV antibody status of donor and recipient, or factors that affect the patients condition and immune status, such as allogeneic versus autologous BMTX, severity of GVHD and pre-BMTx pulmonary function (321).

The histopathologic presentation of the disease is characterized by mononuclear infiltrates in the interstitial septal wall, haemorrhagic congestion and thickening of the septal wall (261). The histology varies considerably, often due to secondary bacterial, fungal and P. carini infections. As a result screening for characteristic histologic changes of the inflamed. Inng tissue is a specific but insensitive tool for the diagnosis of pulmonary CMV infections (101, 218). Demonstration of CMV antigens in cells obtained by BAL is also highty specific, but unfortunately the sensitivity of this diagnostic procedure is also unacceptably low (101).

Strategies to prevent CMV-induced ILD include the use of CMV-seronegative blood for seronegative patients, seronegative donors and administration of intravenous globulin for patients at risk for CMV infection (94). 
The pathogenesis of CMV-induced ILD is incompletely understood and the different findings described by several researchers have not provided an agreement on the pathogenetic mechanisms involved. Major risk factors described for ILD in bone marrow transplant recipients are total body irradiation, CMV infection, and $\mathrm{GVHD}(30,131,252)$. The statistical relation between CMV, ILD and GWHD has led to the assumption that CMV-induced ILD is "an immunopathologic process". This idea was thought to be supported by the absence of ILD in patients receiving autologic BMTX (321) and by experimental evidence in animal models showing that induction of GVHD was a prerequisite for ILD, although the extend of GVHD was not exactly described in these studies $(132,268,269,300)$. In man it is not elear whether there is a causal relationship between ILD and GVHD. It is also not established whether CMV infection and CMV-induced ILD occur prior to GWHD or that GVHD takes place first. Furthermore, potential confounders, such as rejection treatment, can influence the relation between CMV infection and ILD on the one hand and GWHD on the other hand. In general, for the treatment of GvHD immunosuppression will be increased, leading to an increased impairment of the cellular immune response and to the resolution of GWHD. In general factors that contribute to symptomatic disease, i.e. the replication of an infectious agent and the immune response to the invasive agent, are probably both involved in the pathogenesis of ILD in BMT recipients. So, on the one hand viral replication becomes possible during impaired immune conditions and on the other hand the virus infection elicits a local immune response that contributes to ILD.

CMV escapes from immune recognition after alllogeneic BMTX by an impaired MHC-1 restricted cytotoxic T-lymphocyte (CTL) response. The impaired CTL response results in high mortality from CMV-induced ILD (235). The inability of CMV-infected cells to utilize lymphocyte function-associated antigen 1 results in an impaired $\mathrm{MHC}-1$ nonrestricted cytotoxic response (86). In vitro, CMV can upregulate lymphoid functions at low virus concentrations. However, an inhibition of antigen specific mitogenesis, interferon production and cytotoxic T-cell induction is found at high virus titres (321). Enveloped free virus particles bind to $\beta_{2}$-microglobulin by which escape from immune recognition is possible (321).

The local immune response to CMV in allogeneic BMT recipients is thought to be based on resident $\mathrm{T}$-cells of the bronchial epithelium $\left(\mathrm{CD} 8^{+} \mathrm{CD} 5^{*}\right)$ that emerge to the pulmonary air spaces and express activation markers. In addition, macrophages and cytotoxic T-cells are activated as shown by the expression of genes encoding for monokines and serine esterase $B$ (148). This would raise the intriguing paradox of an aggressive local immune reaction. occurring in an otherwise immunocompromised group of patients $(131,207)$. In contrast, others argued that no association was found between ILD and some markers of the immune response like levels of $I F \mathrm{~N}-\gamma$ and IL-2 in BAL fluid and the NK-cell activity against CMV $(321)$.

\section{Antiviral treatment of CMV infections in man}

The control of CMV infection can be achieved by different approaches. On the one hand the multiplication of the virus can be selectively inhibited with antiviral chemotherapy. On the 
other hand the specific immunological control of CMV infection can be enhanced by active vaccination or passive immunoprophylakis, i.e. with high titre antibody therapy or adoptive transfer of specifically stimulated immunocompetent cells. For the timing of the antiviral treatment different approaches exist. Prophylaxis, i.e. prevention of symptoms by treament of all patients at risk; suppression, i.e. treatment as soon as the virus is detected at any site of the body; pre-emptive treatment, i.e treatment dependent on the detection of virus at a certain site of the body; and treatment, as soon as a proven symptomatic infection presents (209). In. the last years, there have been many attempts to attack CMV infection early, by prophylaxis, suppression or pre-emptive treatment.

Only two antiviral drugs, DHPG (ganciclovir) and PFA (foscamet) are licensed for treatment of CMV infections (209). For prophylaxis of CMV infections the use of acyclovir (ACV) is described (14). In addition; intravenous administration of high titre antibody preparations are widely used for the treatment of CMV infections in the immunocompromised host. Combined treatment of antibody preparations and DHPG have been used. The effectiveness of antiviral treatment depends not only on the antiviral drug and regimen used, but is also related to the kind and degree of the immunodeficiency.

\section{DHPG}

The antiviral drug 9-(1,3-dihydroxypropoxymethyl)guanine (DHPG), referred as ganciclovir (CymeveneB, Syntex Inc.) was for the first time described to be effective for treatment of CMV infections in $1986(66)$, five years after its discovery $(9,196)$.

The antiviral drug acts as a guanosine analogue and it differs structurally from endogenous guanosine by the presence of a methoxy group at the 3' carbon of the acyclic side chain. When converted in infected cells to its triphosphate form, DHPG inhibits the DNA polymerase of CMV and other herpes viruses (197). At high concentrations it has also an effect on non-infected cells and unfortunately one of the adverse reactions in vivo is granulocytopenia. Also, thrombocytopenia, CNS effects, nausea, fever, rash, gastrointestinal disorders and toxic effects on the gonads are described $(47,82)$. A major draw back for clinical use is the poor bioavailability, which is about $6 \%(211)$. After oral treatment the availability is even lower (about 3\%) (152). Once DHPG triphosphate is formed, it appears to be very stable and persists for days in CMV-infected cells (25). DHPG has been shown to be therapeutically effective against CMV disease in man $(66,124,272)$. The therapeutic activity of DHPG is determined at $10 \mathrm{mg} / \mathrm{kg} /$ day after generalized. CMV infections $(66,124)$. At that dose DHPG treatment reduced mortality from $C M V$ infection $(6,82,144,180$ ).

In AIDS patients DHPG is effective against CMV-induced (chorio)retinitis. Consequently, the drug is considered the primary drug of choice to treat CMV-retinitis in AIDS patients (66, $105,144)$. It seems also effective to treat gastrointestinal involvement of CMV infection (66, 78). However, maintenance therapy is required to forestall progression of disease (205), with local subtherapeutical drug concentrations (172). This may lead to the development of resistance (98). Decreased phosphorylation of DHPG to its active form has been observed in cells infected with resistant strains (81). An improved outcome of neurological complications, 
like polyradiculopathy, after DHPG treatment is reported $(65,107)$. The effectiveness of DHPG treatment on CMV-induced $\mathrm{LD}$ is not established (70). Although treatment had an effect on virologic parameters, gastro-enteritis did not improve clinically by DHPG treatment in this patient group (244).

Also, in allogeneic bone marrow transplant recipients clear evidence of an antiviral effect was demonstrated, but treatment of disease seemed to be less effective (272). These findings are consistent with later reports about the limited effect of DHPG treatment on HCMV-induced ILD in allogeneic BMT recipient patients $(71,99)$. However, early treatment of these patients with positive surweillance cultures effectively prevented CMV disease, including ILD (124, 257).

In addition, prophylactic administration of DHPG in patients at risk for CMV infection abrogates CMV-induced ILD and reduces the incidence of CMV infection in these patients $(301,310)$.

After renal transplantation (pre-emptive) treatment with $\mathrm{DHPG}$ in combination with a decrease of immunosuppression diminished CMV related disease $(104,203,279)$. In lung transplant recipients DHPG treatment reduced viraemia and virus shedding, but not ILD. Although the clinical outcome of DHPG treatment in heart transplant recipients is limited, prophylaxis with DHPG reduces the incidence of CMV disease in such organ transplant recipients with a high level of immunosuppression (203). Thus, DHPG treatment has a limited effect on clinical CMV infections and attention must be focused on prevention and pre-emptive treatment. Resistance of CMV for DHPG emerges frequently leading to increased therapeutic failure (292).

\section{Acyclovir}

Like ganciclovir, 9-(2-hydroxyethoxymethyl)guanine (acyclovir, ACV, Zovirax(B), Wellcome foundation) is a nucleotide analogue. As the in vitro activity of ACV against CMV is minimal, the drug seems not to be therapeutically effective against CMV infections. However, prophylactically the drug appeared to be effective in very high doses to prevent morbidity, including ILD and mortality from CMV infection whether administered as single drug treatment in kidney, heart and bone marrow transplant recipients $(14,206,305)$ or in combination with CMV intravenous immunoglobulins (IVIG) in liver transplant recipients (290).

\section{PFA}

Trisodium phosphonoformatic acid (PFA, foscarnet, Foscavir(B, Astra Pharmaceutical Prod. ucts, Inc.) is a pyrophosphate analogue. PFA inhibits non-competitively and binds reversibly the viral DNA polymerases of all human herpes viruses forming an inactive complex of foscarnet and DNA polymerase. As a result the drug inhibits the viral replication.

Clinically, the antiviral drug is effective for the treatment of CMV retinitis and gastrointestinal ulcers in AIDS patients and improves survival more effectively than DHPG $(6,26)$. It is, however, not effective for the treatment of ILD in BMT recipients (8). 
The major adverse effect of PFA is nephrotoxicity being the dose-limiting toxicity. Adjustment of the dosage according to the creatinine clearance and regulation of the bydration reduces the nephrotoxicity. In addition, PFA can cause hypocalcemia and treatment is associated with seizures and penile ulcers. Another dose limiting effect is the short half life of the drug (151). Resistance of CMV has been described for PFA in vitro as well as in casuistic reports $(84,168)$.

\section{MPMPC}

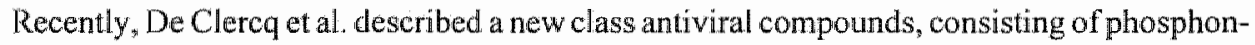
ate derivatives of acyclic mucleoside analogues, active against many DNA viruses including CMV (75). The utility of these compounds, also considered as nucleoside-5'-monophosphates, is independent of thymidine kinase enzymes because the first virus dependent phosphorylation step that is required for activation of nucleoside analogues is by passed (76). (S)-1-(3-hydroxy-2-phosphonylmethoxypropyl)cytosine (HPMPC) is the most potent and selective inhibitor of its class for CMV infections in vitro and in vivo $(5,215)$. HPMPC acts on the viral DNA polymerase. The exact mechanism of inhibition is not yet elucidated (214). Additional advance of HPMPC over DHPG is the long intracellular half live of its active metabolites $(32,145)$, the low grade of resistance and the minimal effect on DNA repair mechanisms in non-infected cells (60).

The drug can be suitable for toplical and systemic treatment of herpes simplex virus infections in man $(174,278)$. In animals it has been shown that HPMPC has a long acting effect on CMV retinitis (113) and on generalized CMV infection $(213,215,217)$.

The major adverse effect of HPMPC in vivo is renal toxicity, which can be avoided by probenecid administration (De Clercq, personal communication).

\section{Immunoglobulins}

Intravenous treatment with hyper immune serum (HIS) containing polyclonal antibodies directed against CMV has been widely used, especially for treatment of CMV-induced ILD after allogeneic BMTx. HIS is generally obtained from CMV-seropositive donors with high CMV antibody titres, but the qualification of the preparations is not well established and depends on the donor population used (280). Furthermore, the effect of HIS treatment may largely depend on the kind of immunosuppression in the host system. The beneficial effect of HIS treatment is most promising in bone marrow transplant and kidney transplant recipients in which the viremic phase seems to be significantly shortened and the rate of interstitial pneumonitis diminished $(205,281,312)$. However, the mechanism by which HIS acts is largely unknown.

Some of the following mechanisms could play a role in the effect of intravenous administration of immunoglobulin: antigen-antibody complexes binding the Fc-receptor for IgG on phagocytic cells; idiotype antibodies recognition by antiidiotype antibodies, which can neutralize 
auto-antibodies and bind and down regulate B-cell receptors for auto-antibodies: antiidiotype antibody or idiotype-antiidiotype complex recognition by $T$-cells (91).

HIS combined with DHPG reduces mortality from HCMV pneumonitis in BMT recipients $(95,191,209,243,253)$ and administration at the time that viral shedding is identified reduces the subsequent risk at CMV disease (124, 191).

\section{Animal models for cytomegalovirus infections}

To increase the understanding of the pathogenesis and treatment of CMV infections animal models are indispensable. There are many cytomegaloviruses, which are all specifically restricted to their own host system (303). Table 3 presents the best known animal cytomegaloviruses described (285). The animal cytomegaloviruses most frequently used for studying the behaviour of cy tomegaloviruses are murine CMV (MCMV), mostly used for immunological studies, guinea pig CMV, which offers a good model for studies on congenital infections, and rat CMV (RCMV) which can be used for transplantation associated infections. For studies on generalized $\mathrm{CMV}$ infections most suitable are the murine and rat models. Studies on RCMV are expanding to form $10 \%$ of presently written literature.

\section{Murine CMV}

The mouse has been exploited by many investigators as an animal model for CMV pathogenesis and biology. It probably started with an early report of intranuclear inclusion bodies in the liver of healthy mice (110) and expanded after propagation in tissue culture was possible (276). MCMV is a suitable virus to study the pathogenesis of CMV infections because its host is relatively small and inexpensive. The genome of the virus consists of a linear double-stranded DNA molecule consisting of one long unique sequence without terminal or internal repeat regions, unlike HCMV (92). Further, transcription is arranged by a cascade reaction (162). MCMV can cause a wide range of symptoms and it involves different organs dependent on the route of administration, the strain and the age of the mice used (285). Intranasal, intratracheal and intraperitoneal administration of MCMV led to severe pulmonary involvement (285). In the mice it has been shown that T-lymphocytes are important in the pathogenesis of MCMV-induced pneumonitis (242). The role of the humoral immune response during acute, chronic or latent infections is not well understood. Current concepts, however, recognize the role of antibodies in the neutralization of viral infectivity (266) and antibody-dependent cell-mediated immunity $(195,234)$ in generallized MCMV infection. Neutralizing and non-neutralizing monoclonal antibodies directed against single MCMV polypeptides are protective against lethal MCMV infection in vivo (103).

MCMV models also have been used for evaluation of antiviral treatment. It was found that in immunosuppressed and immunocompetent mice combined antibody and DHPG treatment seemed to be more effective than treatment with either antibodies or DHPG allone (254). 


\section{Chapter I}

Table 3. Animal cytomegaloviruses:

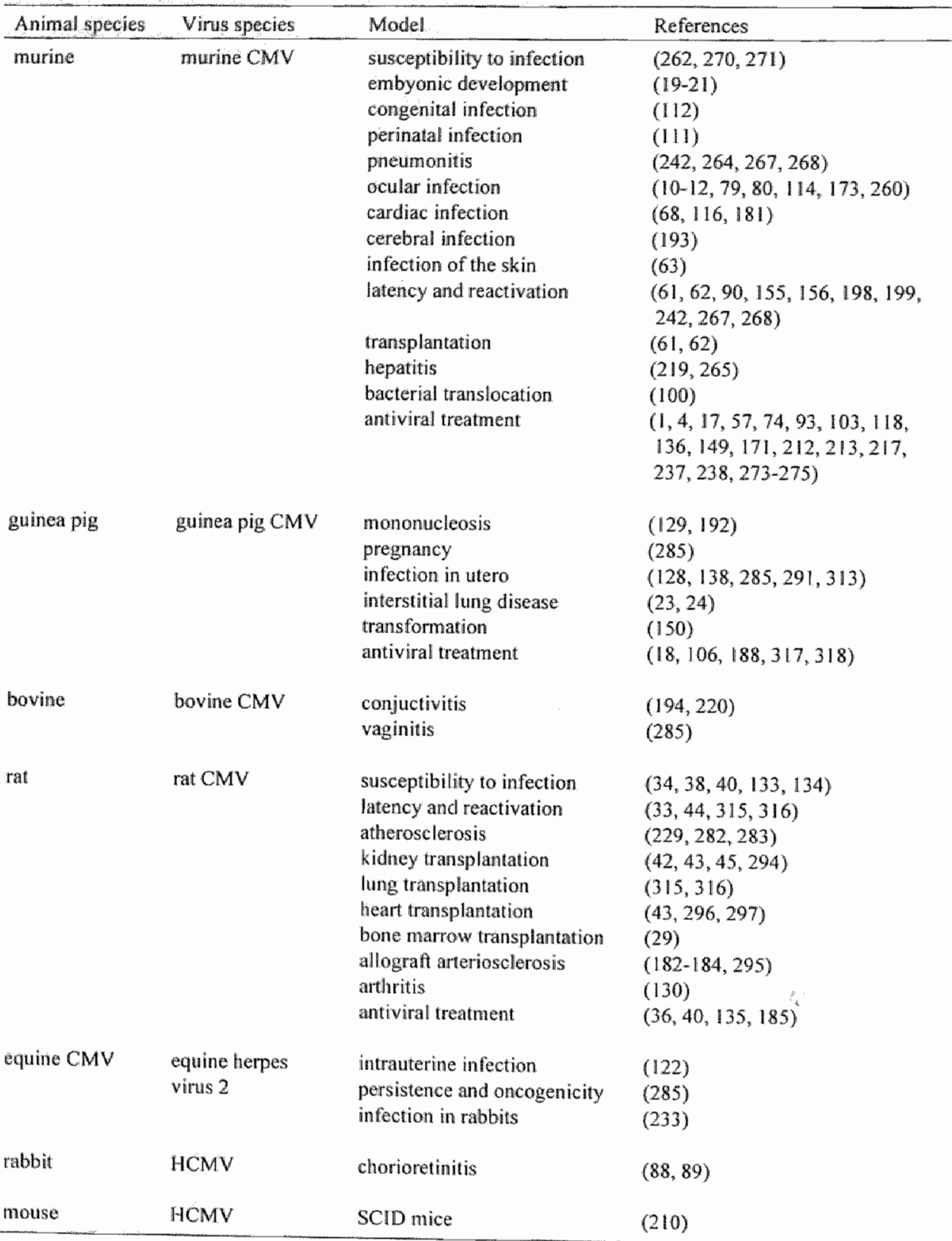




\section{Rat CMV}

\section{Structure, replication and classification}

Rat cytomegalovirus (Maastricht strain) was isolated from the salivary glands of wild brown rats (Rattus Norvegicus) (39). After passage in several Brown Norway laboratory rats (35) and several in vitro passages in rat embryonal fibroblasts (REF) the virus was characterized morphologically and biochemically $(200,201)$.

The nucleocapsid has an overall diameter of $92-95 \mathrm{~nm}$, and is surrounded by an envelope of variable shape and size. Data, obtained by restriction endonuclease mapping revealed a genome consisting of linear double stranded DNA with a molecular weight of $138 \cdot 10^{6}$ Dalton (201). The RCMV genome consists of a 224 kilobase pairs large unique long fragment, without internal inverted repeat sequences, like MCMV and guinea pig CMV but unlike HCMV (200). After $\mathrm{CsCl}_{2}$ gradient centrifugation an RCMV DNA band emerged at a buoyant density of 1.716 , corresponding to a $\mathrm{G}+\mathrm{C}$ content of $57 \%$, which closely resembles the density of HCMV DNA (201). The genes coding for DNA polymerase, mDNA binding protein (MDBP), infected cell protein (ICP) 18.5, glycoprotein B and G-coupled receptor (GCR) protein closely resemble those of MCMV and HCMV (Bruggeman, personal communication). In addition, from an English strain of RCMV, consisting of a $206 \mathrm{~kb}$ large DNA the immediate-early genes were described to resemble those of HCMV and MCMV $(50,256)$. Analyses of the immediate early encoding locus revealed at least two IE genes (IE1, IE2) transcribed by differential splicing. The first three exons are spliced to exon 4 to form IEI and to exon 5 to form IE2. The structural organisation of the IE encoding locus of this RCMV strain is therefore similar to that of HCMV and MCMV (256).

During RCMV infection two categories of proteins appear in the infected cells, the proteins associated with the virion, i.e. the structural proteins, and the proteins, which are not associated with the virus particle, i.e. the nonstructural proteins. The biological significance of these proteins is not yet elucidated.

RCMV is not yet officially classified. According to the biochemical and biological characteristics and the in vivo behaviour of virus described below it should be classified to the Subfamily of the Betaherpesviridae.

\section{Biological properties}

RCMV is restricted to its specific host, since it is not capable to infect cells of human or mouse origin $(35,39)$. In vitro the infection cycle of the virus is 18 to 24 hours. The cytopathic effect of RCMV to rat embryonal fibroblast (REF) cells occurs after 3 to 7 days dependent on the viral load of the inoculum. It is characterized by enlargement of the infected cell, a large nucleus and eosinophilic nuclear inclusions as shown by the haematoxylin-eosin staining. RCMV enhances the procoagulant activity of cultured endothelial cells (299). In heart endothelial cells RCMV directly induces class 11 antigens, possibly by a pathway independent of IFN- $\gamma$ (296). 
In wivo RCMV infection is mostly established by intraperitoneal (i.p.) injection of a virus suspension. Early after i.p. infection an influx of mononuclear cells into the peritoneal cavity is observed. The virus is rapidly cleared from the peritoneal cavity by an uptake into peritoneal macrophages (37), which are altered in function and in which arachidonic acid metabolism is inhibited at 3 days post infection (p.i.) (96). CMV infection in immunocompetent rats results in an acute asymptomatic infection. At three days after intraperitoneal virus infection small amounts of virus are recovered from the spleen and other internal organs. RCMV infection develops in a wide range of cells mainly in cells from mesothelial origin as well as in brown fat cells (34). After the acute phase of infection the infection becomes chronical. During the chronic phase of infection, which starts at about 2 weeks p.i., no infectious virus was detected in the internal organs, but it could be recovered from the salivary glands. At that time specific CMV-directed antibodies are developed. After a few months, no virus was recovered from any organ, but CMV persisted in the body in a latent state $(35,38)$. Organs, such as kidneys and hearts, transplanted from a latently infected donor can transfer the wirus into a non-infected recipient rat. Under immunocompromised conditions the virus reactivates, again resulting in. a symptomatic infection in several internal organs (29).

Although acute and latent CMV infections in rats seemed to be harmlless, virus infection induced vascular injury in the rat as marked by minimal endothelial damage and a significant increase in the number of leucocytes adhering to the aortic intima (283). An electron microscopic study revealed that RCMV caused swollen endothelial cell formation with a surface showing blels and microvilli formation and lipid accumulation in the endothelial celis and the subendothelial space. Leucocyte infiltration in the subendothelium was observed. Ultimately endothelial cells loosened after CMV infection. These pathologic changes were similar to the histopathology induced by hypercholesterolaemia in rats (282).

As opposed to adult rats, in which CMV infection did not elicit overt disease, severe symptoms of purpura and multiple haemorrhages occurred in new-born rats (unpublished observations). After renal transplantation acute RCMV infection did not influence the acute allograft function (45) and survival was not affected. The infection became chronic within 2 weeks p.i. and latent within 6 weeks p.i. dependent on the rat strain. The presence of allogeneic cells is an important factor for reactivation of latent virus (44).

In addition, after lung transplantation in rats, acute allograft reaction led to reactivation of RCMV. The virus was preferably located at the regions where obliterative bronchiolitis developed. This association may affect the function and survival of lung allografts and ultimately of the recipient ( $3 \llbracket 6)$.

As discussed previously RCMV can alter endothelial cells in vitro and in vivo. In aortic allografts the course of arteriosclerosis is enhanced as indicated by an increased influx of inflammatory cells into the adventitia and an increased neointima formation $(184,187)$. In addition, after CMV infection in rat aortic allografts smooth muscle cell proliferation has enthanced (183) and the virus caused subendothelial inflammation in the allograft vascular wall (169). Triple drug immunosuppression significantly reduced the amount of infectious virus, the immune activation and allograft arteriosclerosis in CMV-infected aorta allografts. 
(186). CMV infection of proliferating smooth muscle cells was found after denudation of large arteries in rats (229).

In allogeneic bone marrow recipient rats RCMV infection seemed not to affect the course of acute graft versus host disease (29). However, a graft versus host reaction seemed to be associated with reactivation of latent RCMV (33).

Only few data exist about the effect of antivirals on RCMV infections in vitro and in vivo. In RCMV-infected immunocompromised rats treatment with pro-acyclovir at nearly toxic dosages (100 mg/kg body weight) during continues infusion could slightly reduce the virus titres (36).

As can be concluded from the data provided so far the viral characteristics and the biological behaviour of rat cytomegalovirus and human cytomegalovirus showed striking similarities. These similarities provide that RCMV is a relevant model to study the pathogenesis and therapeutic approaches of CMV infections.

\section{References}

1. Adans, A., M. Mohrman, A. G. Johnson, A. Morin, and E. Deschanns-de-Paillette, 1992. Polyadenylic:polyuridylic acid-induced protection of BALB/c nice against acute murine cytomegalovirus infection. J. Gen. Wirol 73 (Pt 9):2409-2413.

2. Adler, S. P. 1986. Cytomegalovirus infection in parents of children at day-care centers [letter]. $N$. Engl. J. Med. 315:1164-1165.

3. Anders, D. G., and S. M. Punturieri. 1991. Multicomponent origin of cytomegalovirus lytic-phase DNA replication. $J$. Virol. 65:931-937.

4. Anderson, K. P.y. Y. S. Lie, M. A. Low, and E. H. Fennie. 1993. Effects of tumor necrosis factor-alpha treatment on mortality in murine cytomegalovirus-infected mice. Antiviral. Res. 21:343-355.

5. Andrei, G., R. Snoeck, D. Schols, P. Goubau, J. Desmyter, and E. De-Clercq. 1991 "Comparative activity of selected antiviral compounds against clinical isolates of human cytomegalovirus. Eur.J. Clin. Microbiol. Infect. Dis. 10:1026-1033.

6. Anon. 1992. Mortality in patients with the acquired immunodeficiency syndrome treated with either foscarnet or ganciclovir for cytomegalovirus retinitis. Studies of Ocular Complications of AIDS Research Group, in collaboration with the AIDS Clinical Trials Group lpublished erratum appears in N Engl J Med 1992 Apr 23;326(17):1172] [see comments]. N. Engl. $J$. Med. 326:213-220.

7. Arabia, F. A., L. J. Rosado, C. L. Huston, G. K. Sethi, and I. G. Copeland 3d. 199 3. Incidence and recurrence of gastrointestinal cytomegalovirus infection in heart transplantation. Amw. Thoroce Sterg. $55: 8-11$.

8. Aschan, J., O. Ringden, P. Ljungman, B. Lonnqvist, and S. Ohlman. 1992. Foscarnet for treatment of cytomegalowirus infections in bone marrow transplant recipients. Scand. J. Infect. Dis. 24:143-150.

9. Ashton, W. T., J. D. Karkas, A. K. Field, and R. L. Tolman. $₫ 982$. Activation by thymidine kinase and potent antiherpetic activity of 2'-nor-2'-deoxyguanosine (2'NDG). Biochem. Biophys. Res. Commun. 108:1716-1721.

10. Atherton, S. S., C. K. Newell, M. Y. Kanter, and S.W. Cousins. 1991. Retinitis in euthymic mice following inoculation of murine cytomegalovirus (MCMV) viat the supraciliary route. Curr. Eye. Res. 10:667-677. 
11. Bate, J. F, Jr, M. E. ONeil, and R. Folberg. 1991. Murine cytomegalovirus ocular infection in immunocompetent and cyclophosphamide-treated mice. Potentiation of ocular infection by cyclophosphamide. Mvest. Ophuhalmol. Vis. Sci. 32:1749-1.756.

12. Bale, J.F., Jr. M. E. ONeil, R. N. Hogan, and E. R. Kern. 1984. Experimental murine cytomegalowirus infection of ocullar structures. Arch. Ophthalmol. 102:1214-1219.

13. Balfour, H. H. Jr: 1990. Management of cytomegalovirus disease with antiviral drugs. Rew. Infect. Dis. 12 (suppi. 7 ): $\$ 849-\$ 860$.

14. Balfour, H. H., Jr., B. A. Chace, I. T. Stapleton, R. L. Simmons, and D. S. Fryd. 1989. A randomized, placebo-controlled trial of oral acyclowir for the prevention of cytomegalowirus disease in recipients of renal allografts [see comments]. N. Engl J. Med. 320:1381-1387.

15. Balfour, H. H., Jr., and $\mathbb{R}$. C. Hewssner. 1993. Cytomegalovirus infections and liver transplantation: an overview. Transplant. Proc. 25:2012-2013.

16. Ballard, R. A., W. L. Drew, K. G. Hufnagle, and P. A. Riedel. 1979. Acquired cytomegalowirus infection in preterm infants. Amer. J. Dis. Child. 133:482-485.

17. Banister, S., and C. Pomeroy. 1993. Effect of ganciclovir on murine cytomegalovirus-induced reactivation of toxoplasma pneumonia. J. Lab. Clim. Med. 122:576-580.

18. Barnard, D. L., J. H. Huffman, R. W. Sidwell, and E. J. Reist. 1993. Selective inhibition of cytomegalowiruses by 9 -( $3^{\prime}$-ethylphosphono-1'-hydroxymethyl-1'-propyloxy-methyl) guanime. $A n$ tiviral. Res. 22:77-89.

19. Baskar, J. F, and E. S. Huang. 1981. Effect of murine cytomegalovirus on implantation stage mouse embryos. Proc. Soc. Exp. Biol. Med. 167:581-587.

20. Baskar, J. F., S. C. Stanat, and E. S. Huang. 1985. Congenital defects due to reactivation of latent murine cytomegaloviral infection during pregnancy. J. Infecr. Dis. 152:621-624.

21. Baskar, J. F., S. C. Stanat, K. K. Sulik, and E. S. Huang. 1983. Murine cytomegalowirus-induced congenital defects and fetal maldevelopment. $J$. Infect. Dis. 148:836-843.

22. Benko, D. M., R. S. Haltiwanger, G. W. Hart, and W. Gibson. 1988. Virion basic phosphoprotein from human cytomegalovirus contains $\mathrm{O}$-linked $\mathrm{N}$-acetylglucosamine. Proc. Natl. Acad. Sci. U.S. A. $85: 2573-2577$.

23. Bia, F. J., B. P. Griffith, C. K. Fong, and G. D. Hsiung, 1983. Cytomegalowiral infections in the guinea pig: experimental models for human disease. Rev. Infect. Dis. 5:177-195.

24. Bia, F. J., H. L. Lucia, C. K. Fong, M. Tarsio, and G. D. Hsiung. 1982. Effects of vaccination on cytomegalovirus-associated interstitial pneumonia in strain 2 guinea pigs. $J$. Infect. Dis. 145:742-747.

25. Biron, K. K., S. C. Stanat, J. B. Sorrell, J. A. Fyfe, P. M. Keller, C. U. Lambe, and D. J. Nelson. 1985. Metabolic activation of the nucleoside analog $9 \cdots[(2-h y d r o x y m$ - (hydroxymethyl)ethoxy] methyl)guanine in human diploid fibroblasts infected with human cytomegalovirus. Proc. Natl. Acad. Sci. U. S. A. $82: 2473 \times 2477$.

26. Blanshard, C. 1992. Treatment of HIV-related cytomegalovirus disease of the gastrointestinal tract will foscarnet. J. Acquir. Immune. Defic. Syndr. 5 (Suppl. 1):S25-S28.

27. Bloom, J.N., and A. G. Palestine. 1988. The diagnosis of cytonegalowirus retinitis. Amm Imern Med. 109:963-969.

28. Borysiewicz, L. K., J. K. Hickling, S. Giraham, J. Sinclair, M. P. Cranage, G. L. Smith, and J. G. Sissons. 1988. Human cytomegalovirus-specific cytotoxic $T$ cells. Relative frequency of stage-specific Cl'L recognizing the $72-\mathrm{kD}$ immediate early protein and glycoprotein $\mathrm{B}$ expressed by recombinant vaccinia viruses. J. Exp. Aed. 168:919-931.

29. Bos, G. M., G. D. Majoor, C. A. Bruggeman, G. Grauls, M. J. van-de-Gaar, and P. J. van-Breda-Vriesman. 1989. Rat cytomegalovirus can be transferred by bone marrow cells but does not affect the course of acute graft-versus-host disease. Transplant. Proc. 21 (Pt 3):3050-3052. 
30. Bostrom, L, O. Ringden, J. W. Gratama, N. Jacobsen, H. G. Prentice, F, E. Zwaan, and B. Nilsson. 1990. A role of herpes virus serology for the development of actute grat-versus-liost disease. Leukaemia Working Party of the European Group for Bone Marrow Transplantation. Bone Mfamow Tramsplant. 5:321-326.

31. Bradshaw, P. A., M. Duran, E. Lee, L. Young, G. R. Reyes, S. Perkins, H. Pande, and S. K. H. Foung. 1991. Anti-CMV monoclonal antibodies epitope identification and immune response analysis. $h$. Progress in cytomegalowirus research. M. P. Landini, editors. Elsevier Science Publishers B.W: Amsterdami. 157-160.

32. Bronson, I. J., H. T. Ho, H. De-Boeck, K. Woods, I. Ghazzouli, J. C. Martin, and M. J. Hitchcock. 1990. Biochemical pharmacology of acyclic nucleotide analogues. Amn. N. Y. Acad. Sci. 616:398-407.

33. Bruggeman, C. A. 1991 . Reactivation of latent CMV in the rat. Tramsplaw Proc. 23 (Suppl 3):22-24.

34. Bruggeman, C. A., J. H. Bruning, G. Grauls, A. E. van-den-Bogaard, and F. Bosman. 1987. Presence of cytomegalovirus in brown fat. Study in a rat model. Intervinology $27: 32-37$.

35. Bruggeman, C. A., W. M. Debie, G. Grauls, G. Majoor, and C. P. van-Boven. 1983. Infection of laboratory rats with a new cytomegalo-like virus. Arch. Kirol 76:189-199.

36. Bruggeman, C. A., W. Engels, and J. Endert. 1987. Treatment of experimentall cytomegalovirus infections with acyclovir. Arch. Firol. $97: 27-35$.

37. Bruggeman, C. A., G. Grauls, and C. P. A. van Boven. 1985. Susceptibility of peritoneal macrophages to rat cytomegalovirus infection. FEMS 27:263-266.

38. Bruggeman, C. A., H. Meijer, F. Bosman, and C. P. van-Boven. 1985 . Biology of rat cy tomegalovirus infection. Intervirology. 24:1-9.

39. Bruggeman, C. A., H. Meijer, P. H. J. Dormans, W. M. H. Debie, G. E. H. M. Grauls, and C. P. A. van Boven. 1982. Isolation of a cytomegalovirus-like agent from wild rats. Arch. Virol. 73:231-241.

40. Bruggeman, C. A., H. Schellekens, G. Grauls, W. M. H. Debie, and C. P. A. van Boven. 1983. Rat cytomegalovirus: induction of and serisitivity to interferon. Aniwirat. Res. 3:315-324.

41. Bruggeman, $C_{m} A_{n}$ and $M_{*}$ C. van-Dam-Mieras. 1991. The possible rolle of cytomegalovirus in atherogenesis. Prog. Med. Virol. 38:1-26.

42. Bruning, J. H. 1988. Cytomegalovirus intections in renal transplantation. Study in a rat model [Ph, D. Thesis], University of Limburg, Maastricht.

43. Bruning, J. H., C. A. Braggeman, C. P. van-Boven, and P. J. van-Breda-Vriesman. 1986. Passive transfer of cytomegalovirus by cardiac and renal organ transplants in a rat model. Tramsplantarion. 41:695-698.

44. Bruning, J. H., C. A. Bruggeman, C. P. van-Boven, and P. J. van-Breda-Vriesman. 1989. Reactivation of latent rat cytomegalovirus by a combination of immumosuppression and administration of allow geneic immunocompetent cells. Thansplankarion 47:9!7-918.

45. Bruning, J. H. C. A. Bruggeman, and P. J. van-Breda-Viesman. 1989. The effect of cy tomegalovirus infection on renal allograft function and rejection in a rat model. Transplontorton. 47472-744.

4.6. Buckner, F. S., and C. Pomeroy. 1993. Cytomegalovirus disease of the gastrointestinal tract in patients without AIDS. Clin. Infect. Dis. 17:644-656.

47. Bubles, W. C., Jr., B. J. Mastre, A. J. Tinker, V. Strand, S. H. Koretz, and The Symtex Collaborative Ganciclovir Treatment Group. 1988. Ganciclovir treatment of life- or sight-lhreatening cytomeghlovirus infection: experience in 314 immunocompromised patients. Rev. Infect. Dis. 10 (Suppl. 3):\$495-\$506.

48. Bulpitt, K. J., and E. Brahn. 1989. Systemic Lupus erythematosus and concurrent cytomegalowirus wascultis: diagnosis by antemortem skin biopsy. J. Rhenmanol 16:677-680.

49. Burgart, L. J. M. J. Heller, M. J. Reznicek, T. C. Greiner, C. J. Taneyck, and R. A. Robinson. 1991. Cytomegalovirus detection an bone marnow transplant patients with idiopathic pneumonitis. A 


\section{Chapter]}

elinicopathologic study of the clinical utllity of the polymerase chain reaction on open lung biopsy specimen tissute. Am. J. Clin. Pouhol. 96:572-576.

50. Burns, W. H. G. M. Barbour, and G. R. Sandford. 19.88. Mollecular cloning and mapping of rat cylomegalovirus DNA. Wirology, 166:140-148.

51. Cabau, N. M. D. Labadie, C. Vesin, J. Feingold, and A. Boué, 1979. Seroepidemiology of cytomegalovirus infections during the first years of life in urban communities. Arch. Dis. Child. $54: 286-290$.

52. Campadeli-Fiume, G, F. Farabegoli, S. Di-Gaeta, and B. Roizman. 1991. Origin of unenveloped capsids in the cytoplasm of cells infected with herpes simplex virus 1 . J. Virol. 65:1589-1595.

53. Carlström, G. 1965. Virologic studies on cytomegalic inclusion disease. Acta. Paediat. Scand. 54:17-23.

54. Carlström, G., and B. Jalling. 1970. Cytomegalovirus infections in different groups of paediatric patients. Acia. Paediatr. Scand. 59:303-309.

55. Chandler, S. H., E. R. Alexander, and K. K. Holmes. 1985. Epidemiology of cytomegaloviral infection in a heterogeneous popullation of pregnant women. J. Infect. Dis. 152:249-256.

56. Chandler, S. H., K. K. Holmes, B. B. Wentworth, L. T. Gutman, P. J. Wiesner, E. R. Alexander, and H. H. Handsfield. 1985. The epidemiology of cytomegaloviral infection in women attending a sexually transmitted disease clinic. J. Infecr. Dis. 152:597-605.

57. Chapman, A. J., H. E. Farrell, J. A. Thomas, J. M. Papadimitriou, M. J. Garlepp, A. A. Scalzo, and G. R. Shellam: 1994 . A murine cytomegalovirus-neutralizing monoclonal antibody exhibits autoreactivity and induces tissue damage in vivo. Immumology. 81:435-443.

58. Chee, M. S., A. T. Bankier, S. Beck, R. Bohni, C. M. Brown, R. Cerny, T. Horsnell, C. A. Hutchison 3d., T. Kouzarides, J. A. Martignetti, E. Preddie, S. C. Satchwell, P. Tomlinson, K. M. Weston, and B. G. Barrell. 1990. Analysis of the protein-coding content of the sequence of human cytomegalovirus strain AD169. Curr. Top. Microbiol. Immunol. 154:125-169.

59. Chee, M. S., S. C. Satchwell, E. Preddie, K. M. Weston, and B. G. Barrell. 1990. Human cytomegalovirus encodes three $G$ protein-coupled receptor homologues [see comments]. Nature. 344:774-777.

60. Cherrington, J. M, S. J. Allen, B. H. McKee, and M. S. Chen. 1994. Kinetic analysis of the interaction between the diphosphate of (S)-1-(3-hydroxy-2-phosphonylmethoxypropyl)cytosine, ddCTP, AZTTR, and FIAUTP with human DNA polymerases beta and gamma. Biochem. Pharmacol. 48:1986-1988.

61. Cheung, K. S., and D. J. Lang. 1977. Detection of latent cytomegalovirus in murine salivary and prostate explant cultures and cells. Infect. Immun. 15:568-574.

62. Cheung, K. S., and D. J. Lang. 1977. Transmission and activation of cytomegalowirus with blood transfusion: a mouse model. I. Infecr. Dis. 135:841-845.

63. Chong, K. T., and C. A. Mims. 1983. Rash produced by mouse cytomegalovirus. Infect Immun. 41:352-357.

64. Chou, S. W. 1986. Acquisition of donor strains of cytomegalovirus by renal-transplant recipients. $N$. Engl J. Med 314:1418-1423.

65. Cohen, B. A., J. C. MCA rthur, S. Grohman, B. Patterson, and J. D. Glass. 1993. Neurologic prognosis of cytomegalowirus polyradiculomyelopathy in AIDS. Neturology. 43:493-499.

66. Collaborative DHPG Treatment Study Group. 1986. Treatment of serious cytomegalovirus infections with 9-(1,3ndihydroxy-2-propoxymethyl)guanine in patients with AIDS and other immunodeficiencies. N. Engl. J. Med. 314:801-805.

67. Compton, T., R. R. Nepomuceno, and D. M. Nowlin. 1992. Human cytomegalovirus penetrates host cells by $\mathrm{pH}-$ independent fusion at the cell surface. Virology. 191:387-395. 
68. Craighead, J. E., S. A. Huber, and W. B. Martin. 1991. Murine cytomegalovirus myocarditis. Wuan. Heart. J. 12 Suppl D:69-72.

69. Cranage, M. P., T. Kouzarides, A. T. Bankier, S. Satchwell, K. Weston, P. Tomlinson, B. Barrell, H. Hart, S. E. Bell, A. C. Minson, and G. L. Smith. 1986. Identification of the human cytomegalovirus: glycoprotein $B$ gene and induction of neutralizing antibodies via its expression in recombirant vaccinia virus. Embo $J .5: 3057-3063$.

70. Crampacker, C. S., and M. Heath-Chiozzi. 1991. Owerwiew of cytomegulovirus infections in HIV-infected patients: current therapies and future strategies. A. Acquir. Homme. Defic. Symdr. 4 (Suppl. 1):S1-S5.

71. Crumpacker, C., S. Marlowe, J. L. Zhang, S. Abrams, P. Watkins, and Ganciclovir Bone Matrow Treatment Group. 1988. Treatment of cytomegalovirus pneumonia. Rev Infect. Dis: $:$ 538-S546.

72. Curtis, J. L., and B. M. Eggert. 1982. Cutaneous cytomegalovirus vasculitis: an unusual clinical presentation of a common opportunistic pathogen. Hum. Pathol 13:1138-1\|41.

73. Davis, M. G., S. C. Kenney, J. Kamine, J. S. Pagano, and E. S. Huang. 1987. Inmediate-arly gene region of human cytomegalovirus trans-activates the promoter of human immunodeficiency virus. Proc. Natl. Acad. Sci. U. S. A. 84:8642-8646.

74. De-Castro, L. M., E. R. Kern, E. De-Clercq, A. Ghaffar, E. P. Mayer, P. E. Vogt, and J. D. Gangeni 1991. Phosphonylmethoxyalkyl purine and pyrimidine derivatives for treatment of opportunistic cytomegalovirus and herpes simplex virus infections in murine AIDS. Antrival Res. 16:101:114.

75. De-Clercq, E., A. Holy, I. Rosenberg, T. Sakuma, J. Balzarini, and P. C. Maudgal. 1986. A novel selective broad-spectrum anti-DNA virus agent. Nature, 323:464-467.

76. De-Clercq, E., T. Sakuma, M. Baba, R. Pauwels, J. Balzarini, L. Rosenberg, and A. Holy. 1987. Antiviral activity of phosphonylmethoxyalkyl derivatives of purine and pyrimidines. Anuwiral. Res. $8: 26 \rrbracket-272$.

77. DeMarchi, J. M., M. L. Blankenship, G. D. Brown, and A. S. Kaplan. 1978. Size and complexity of human cytomegalovirus DNA. Virology. 89:643-646.

78. Dieterich, D. T "D. P. Kotler, D. F. Busch, C. Crumpacker, C. Du-Mond, B. Dearmand, and W. Buhles. 1993. Ganciclovir treatment of cytomegalovirus colitis in ALDS: a randomized, double-blind, placebo-controlled multicenter study. J. Infect. Dis 167:278-282.

79. DiLoreto, D., Jr., L. G. Epstein, E. S. Lazar, W. J. Britt, and M. del-Cerro. 1994. Cytomegalovirus infection of human retinal tissue: an in wivo model. Lab. Invest. $71: 141-148$.

80. Dix, R. D., C. Cray, and S. W. Cousins. 1994. Mice immunosuppressed by murine retrovirus infection (MAIDS) are susceptible to cytomegalovirus retinit"s. Curr. Eye. Res. 13:587-595.

81. Drew, W. L. 1991. Clinical use of ganciclowir for cytomegalowirus infection and the development of drug resistance J. Acquir. Lmmume. Defic. Syndx. 4 (Stappi. 1),S42,\$46.

82. Drew, W. L. 1992. Cytomegalowirus infection in patients with AIDS. Clim. Infect. Dis. 14:608-615.

83. Drew, W. L. 1992. Nonpumonary manifestations of cytomegalovirus infection in immunocompromised patients. Clin. Microbiol. Rev. 5:204-210.

84. Drobyski, W. R. K. K. Knox, D. R. Carrigan, and R. C. Ash. 1991. Foscarnet therapy of ganciclovirresistant cytomegalovirus in matrow transplantation. Transplantation. $52: 155=157$.

85. Dudding, L., S. Haskill, B. D. Clark, P. E. Auron, S. Spom, and E. S. Huang. 1989. Cytomegalowirus infection stimulates expression of monocyte-associated mediator genes. I. Immunol 143:3343.3352.

86. Duncombe, A. S., J. E. Grundy, P. Oblakowski, H. G. Prentice, D. J. Gottlieb, D. M. Roy, I. E. Reittie, C. Bello-Fernandez, A. V. Hofforand and M. K. Brenner. 1992. Bone marrow transplantrecipients have defective $\mathrm{MHC}$-unrestricted cytotoxic responses against cytomegalowirus in comparison with Epstein-Bart virus: the importance of target cell expression of lymphosyte function-associated antigen I (LFA 1). Blood. 79:3059-3066. 
87. Dunconbe, A. S. A. Meager, H. G. Prentüe, J. E. Grundy, H. E. Heslop, A. Y. Hoffbrand, and M. K. Brenner, 1990. Gamma-interferon and tumor necrosis factor production after bone marrow transplantation is augnemted by exposure to marrow fibroblasts infected with cytomegalovirus. Blood 76:1046-1053.

88. Dumkel, E. C.1991. HCMW-induced chorioretinitis in the rabbit. Transplant Proc. 23 (Suppl 3):25-8, discinsion 28 .

89. Dunkel, E. C, D. de-Freitas, D. I. Scheer, M. L. Siegel, Q. Zhu, R. J. Whitley, P. A. Schaffer, and D. Pavan-Langston. 1993. A rabbit model for human cytomegalovirus-induced chorioretinal disease. $J$. Infect Dis. 168:336-344

90. Dutko, F, J., and M. B. Oldstone. 1981. Cyrtomegalovirus causes a latent infection in undifferentiated cells and is activated by induction of cell differentiation. $\int$ Exp. Med. 154:1636-1651.

91. Dwyer, J. M. 1992. Manipulating the immune system with immune globulin. N. Engl. J. Med. $326: 107-1116$

92. Ebeling, A., G. M. Keil, E. Knust, and U. H. Koszinowski 1983. Molecular cloning and physical mapping of murine cytomegalowirus DNA. $/$. Virol. 47:421-433.

93. Eizuri, Y, N. Nakagawa, R. Hamasuna, and Y. Minamishima. 1992. Protective effect of MDPLys(L 18), a synthetic derivatuve of muramyldipeptide, on murine cytonegalovirus infection. $N a t$. Immun. 11:225-236.

94. Elfenbein, G. J., T. Siddiqui, K. H. Rand, J. Graham-Pole, R. B. Marcus, N. P. Mendenhall, T. M. Goedert, T. Wikle-Fisher, S. A. Gross, and R. S. Weiner. 1990. Successful strategy for prevention of cytomegalowirus interstitial pneumonia after human leukocyte antigen- ¿dentical bone marrow trans: plantation. Rev. Infect. Dix. 12 (Suppl. 7):S805-\$810.

95. Emanuel, D., I. Cunningham, K. Jules-Elysee, J. A. Brochstein, N. A. Kernan, J. Laver, D. Stover, D. A. White, A. Fels, B. Polsky, H. Castro-Malaspina, J. R. Peppard, P. Bartus, U. Hammerling, and

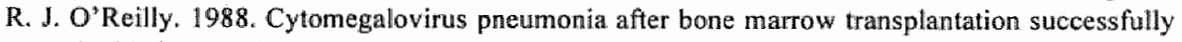
treated with the combination of ganciclovir and high-dose intravenous immune globulin. Anm. Intern. Med. 109:777-782.

96. Engels, W., G. Graulls, P. I. Lemmens, W. J. Mullers, and C. A. Bruggeman. 1989. Influence of a cytomegallovirus infection on functions and arachidonic acid metabolism of rat peritoneal macrophages. I. Leukoc. Biol. 45:466-473.

97. Erice, A. 1991. Diagnosis of cytomegalovirus pneumonitis after bone marrow transplantation. Is PCR the answer? [edlitorial], Am. J. Cliw. Paihol, 96:564-567.

98. Erice, A., S. Chou, K. K. Biron, S. C. Stanat, H. H. Balfour Jr., and M. C. Jordan. 1989. Progressive disease due to ganciclowir-iesistant cytomegalovirus in immunocompromised patients. $N . E n g l . J$. Med. 320:289.293.

99. Erice, A. M. C. Jordtan, B. A. Chace, C. Fletcher, B. J. Chinnock, and H. H. Balfour Jr. 1987. Ganciclovir treatment of cytomegalovirus disease in transplant recipients and other immunocompromised hosts. Jama 257/3082-3087.

100. Erickson, E. J., J. R. Saflle, S. E. Mortis, J. J. Sullivan, E. J. Eichwald, and J. Shelby. 1990. Cytomegalovirus infection promotes bacterial translocation in thermally injured mice. $y_{\text {. Bum }}$. Care. Rehabil. $\| 1: 428-435$.

101. Eriksson, B.M., M. Brytting, B. Zweygberg-Wirgart, G. Hillerdal, E. Olding-Stenkvist, and A. Linde. 1993. Diagnosis of cytomegallovirus in bronchoalveolar lavage by polymerase chain reaction, in comparison with virus isolation and detection of viral antigen. Sicond. J. Infect. Dis. 25:421 427.

102. Erlich, K. S., J. Mills, and J. D. Shanley. 1989. Effects of L3T4t lymphocyte depletion on acute murine cytomegalovirus infection. I. Gen. Firol. 70 (Pt 7):1765-1771. 
103. Farrell, $\mathbb{H}, \mathrm{E}_{\text {. }}$, and $\mathrm{G}$. R. Shellam. 1991 . Protection against murüe cytomegalovirus infection by passive transfer of neutralizing and nort-neutralizing monoclomal antibodies. $J$. Gen. Wrol. $72(\mathrm{Pt}$ 1): $149-156$.

104. Farrugia, E., and T. R. Schwab. 1992. Management and prevention of cytomegalowirus infection after renal transplantation. Mayo. Clin. Proc. 67:879-890.

105. Felsenstein, D., D. J. D'Amico, M. S. Hirsch, D. A. Neumeyer, D. M. Cederberg, P. de-Miranda, and R. T. Schooley. 1985. Treatment of cytomegalovirus retinitis with 9-22-hydroxyn-(hydroxymethyll)ethoxymethyl]guanine, Ann. Iniern. Med. 103:377-380.

106 . Feng, J. S., J. Y. Crouch, R. L. Tolman, H. L. Lucia, and G. D. Hsiung. 1992. Combined treatment with $2^{*}$-nor-cGMP and ganciclowir against cytomegalovirus infection in a guinea pig model Amiviral. Res 19:193-206.

107. Fiala, M., L. A. Cone, N. Cohen, D. Patel, K. Williams, D. Casarealle, P. Shapshak, and W. Tourtelotte. 1988. Responses of neurologic complications of AIDS to $3{ }^{\prime}$-azido-3'-deoxythymidine and 9-(1,3-dihydroxy-2-propoxymethyl) guanine. 1. Clinical features. Rev. Infect. Dis. 10:250-256.

108. Fiala, M., J. E. Payne, T. V. Berne, T. C. Moore, W. Henle, J. Z. Montgomerie, S. N. Chatterjee, and L. B. Guze. 1975. Epidemiology of cytomegalovirus infection after transplantation and immunosuppression. J. Inf. Dis. 132:421-433.

109. Fields, B. N., D. M. Knipe, R. M. Chanock, D. M. Hirsch, J. L. Melnick, T. P. Monath, and B. Roizman, 1990. Fundamental wirology. Raven Press, Ltd, New York. 1064 pp.

110. Findlay, G. H. 1932. Intranuclear inclusion bodies in the liver cells of mice. Br. J. Exp. Pathol. 1. $3: 223-229$.

111. Fitzgerald, N. A., J. M. Papadimitriou, and G. R. Shellan. 1990. Cytomegallovirus-induced pneumonitis and myocarditis in newbon mice. A model for perinatal human cytomegalovirus infection. Arch Virol. 115:75-88.

112. Fitzgerald, N. Aw, and G. R. Shellam. 1991. Host genetic influences on fetal susceptibility to murine cytomegalovirus after maternal or fetal infection. J. Infect. Dis. 163:276-281.

113. Flores-Aguilar, M., J. S. Huang, C. A. Wiley, E. De-Clercq, C. Vuong, G. Bergeron-Lynn, B. Chandler, D. Munguia, and W. R. Freeman. 1994. Long-acting therapy of viral retinitis with (S)-1-(3-hydroxy-2-phosphonylmethoxypropyl)cytosine. J. Infect. Dis. 169:642-647.

114. Freeman, W. R., T. E. Schneiderman, C. A. Wiley, A. D. Listhaus, P. Svendsen, D. Munguia, and G. Bergeron-Lynn. 1993. An animal model of focal, subacute, viral retinitis. Retina 13:214-221.

115. Frenkel, L. D., S. Gaur, M. Tsolia, R. Scudder, R. Howell, and H. Kesarwala. 1990. Cytomegalovirus infection in children with AlDS. Rev. Infect. Dis. 12 (Suppl. 7):S820-\$826.

116. Gang, D. L. L. V. Barrett, E. J. Wilson, R. H. Rubin, and D. N. Medearis. 1986. Myopericarditis and enhanced dystrophic cardac calcification in murine cytomegalovirus infection. Am. . Parhol. 124:207-215.

117. Geelen, J., C. Walig, P. Wertheim, and 1. Van Der Noordaa. 1978. Human cytomegalovirus DNA (I. Molecular weight and infectivity). J. Virol. 26:813-816.

118. Gehrz, R. C., C. M. Nelson, and B. E. Kari. 1992. A combination of hurnan cytomegalovirus (HCMV)-specific murine monoclonal antibodies exhibits synergistic antiviral activity in vitro. Antiviral. Res. 17:115-131.

119. Gibson, W. 1983. Protein counterparts of human and simian cytomegaloviruses, Virology 128:391. 406.

120. Gibson, W. 1993. molecular biology of theman cytomegalovirus in Frontiers of virology: Molecular aspects of human cytomegalovirus diseases, vol. 2. Y. Becker, G. Darai, and E.-S. Huang, editors. Springer Verlag, Berlin. 303-330pp. 
121. Gilbert, O. L., K. Hayes, 1. L. Hudson, I. James, and Neonatal Cytomegalovirus Infection Study Group. 1989. Prevention of transfusion-acquired cytomegalovirus infection in infants by blood filtration to remowe leucocytes. Lancet. 1:1228-1231.

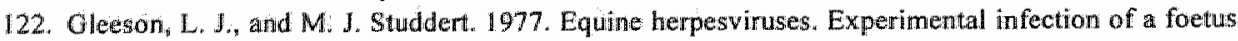
with type 2. A ust. Vet. J. 53:360-362.

123. Goodpasture, E. W., and F. B. Talbot. 1921. Concerning the nature of "protozoan-like" cells in certain lesions of infancy. Amer. J. Dis. Child 21:415-425.

124. Goodrich, J. M. M. Mori; C. A. Gleaves, C. Du-Mond, M. Cays, D. F. Ebeling, W. C. Buhles, B. DeArmond, and J. D. Meyers. 1991. Early treatment with ganciclovir to prevent cytomegalovirus disease after allogeneic bone marrow transplantation. $N$. Engl. J. Med. 325:1601-1607.

125. Greenberg, S. B., S, Linder, B. Baxter, E. Faris, D. M. Marcus, and G. Dreesman. 1984. Lymphocyte subsets and urinary excretion of cytomegalovirus among homosexual men attending a clinic for sexuallyy transmitted diseases. J. Infect. Dis. 150:330-333.

126. Grefte, A., N. Blom, M. van-der-Giessen, W. van-Son, and T. H. The. 1993. Ultrastructural analysis of circulating cytomegalic cells in patients with active cytomegalovirus infection: evidence for virus production and endothelial origin. J. Infecr. Dis. 168:1110-1118.

127. Grefte, A. M. van-der-Giessen, W. van-Son, and T. H. The. 1993. Circulating cytomegalowirus (CMV)-infected endothelial cells in patients with an active CMV infection. J. Infect. Dis. 167:270277.

128. Griffith, B. P., and M. I. Aquino-de-Jesus. 1991. Guinea pig model of congenital cytomegalovirus infection. Tramsplant. Proc. 23 (Suppl 3) 29-31, discussion.

129. Griffith, B. P., H. L. Lucia, F. J. Bia, and G. D. Hsiung. 1981. Cytomegalovirus-induced mononucleosis in guinea pigs. Infect. Imntw. 32:857-863.

130. Griffiths, M. M., A. D. Sawitzke, D. S. Harper, S. McCalt, V. R. Reese, and G. W. Cannon. 1994. Exacerbation of collagen-induced arthritis in rats by rat cytomegalovirus is antigen-specific. Autommunity. 18:177-187.

131. Grundy, J. E., J. D. Shanley, and P. D. Griffiths. 1987. Is cytomegalowirus interstitial pneumonitis in transplant recipients an immunopathological condition? Lancet. 2:996-999.

132. Grundy, J. E., J. D. Shanley, and G. M. Shearer. 1985. Augmentation of graft-versus-host reaction by cytomegalowirus infection resulting in interstitial pneumonitis. Tramsplantation. 39:548-553.

133. Haagmans, B. L., F. S. Stals, P. H. van-der-Meide, C. A. Bruggeman, M. C. Horzinek, and V. E. Schijns. 1994. Tumor necrosis factor alpha promotes replication and pathogenicity of rat cytomegalovirus. J. Virol. 68:2297-2304.

134. Haagmans, B. L., A. J. van-den-Eertwegh, E. Claassen, M. C. Horzinek, and V. E. Schijns. 1994. Tumour necrosis tactor-alphat production during cytomegalowirus infection in immunosuppressed rats. J. Gen. Virol. 75 (Pt 4):779-787.

135. Haagmans, B. L., P. H. van-der-Meide, F. S. Stals, A. J. van-den-Eertwegh, E. Claassen, C. A. Bruggeman, M. C. Horzinek, and V. E. Schijns, 1994. Suppression of rat cytomegalovirus replication by antibodies against gamma interferon. J. V'irol. 68:2305-2312.

136. Hamasung, R., Y. Eizuru, and Y. Minamishima, 1994. Inhibition by iota-carrageenan of the spread of murine cytonegalowirus from the peritoneal cavity to the blood plasma. J. Gen. Virol. $75(\mathrm{Pt}$ 1): $111-116$.

137. Hamzeh, F.M., P. S. Lietman, W. Gibson, and G. S. Hayward. 1990. Identification of the lytic origin of DNA replication in human cytomegalovirus by a novel approach utilizing ganciclovir-induced chain termination. . Wirol. 64:6184-6195. 
138. Harrison, $C . J$, and R. Burger. 1991. Low maternal CD4 count at inception of gestational cytomegalowirus (CMV) infection and impaired humoral response: effect on congenital CMV infection in the guinea pig. Clin. Immunol. Immunopathol. $60: 171-180$.

139. Hawley, D. A., J. F. Schaefer, D. M. Schulz, and J. Muller. 1983. Cytomegalovirus encephalitis in acquired immunodeficiency syndrome. Am. J. Clin. Parhol. 80:874-877.

140. Heilbronn, R., I. Albrecht, S. Stephan, A. Bürkle, and H. zur-Hausen. 1993. Human cytomegalovirus induces JiC virus DNA replication in human fibroblasts. Proc. Natl. Acad. Sci. U. S. A. 90:1140611410.

141. Henderly, D. E., and L. M. Jampol. 1991. Diagnosis and treatment of cytomegalovirus retinitis. $J$. Acquir. Immune. Defic. Syndr. 4 (Suppl. 1):S6-S10.

142. Hendrix, M. G., P. H. Dormans, P. Kitslaar, F. Bosman, and C. A. Bruggeman. 1989. The presence of cytomegalovirus nucleic acids in arterial walls of atherosclerotic and nonatherosclerotic patients. Am. J. Pathol. 134:1151-1157.

143. Hersman, J., J. D. Meyers, E. D. Thomas, C. D. Buckner, and R. Clift. 1982 . The effect of granulocyte transfusions on the incidence of cytomegalovirus infection after allogeneic marrow transplantation. Ann. Intern. Med. 96:149-152.

144. Hirsch, M. S. 1992. The treatment of cytomegalovirus in AlDS-more than meets the eye. $N$. Engl. J. Med. 326:264-266.

145. Ho, H. T., K. L. Woods, J. J. Bronson, H. De-Boeck, J. C. Martin, and M. J. Hitcheock. 1992. Intracellular metabolism of the antiherpes agent (S)-1-[3-hydroxy-2-(phosphonylmethoxy)propyl]cytosine. Mol. Pharmacol. 41:197-202.

146. Ho, M. 1991. Cytomegalovirus. Biology and Infection. Plenum Medical Book Company, New York. $440 \mathrm{pp}$.

147. Holland, N. R., C. Power, V. P. Mathews, J. D. Glass, M. Forman, and J. C. McArthur. 1994. Cytomegalovirus encephalitis in acquired immunodeficiency syndrome (AIDS). Neurology. 44 (Pt 1):507-514

148. Humbert, M., O. Devergne, J. Cerrina, B. Rain, G. Simonneau, P. Dartevelle, P. Duroux, P. Galanaud, and D. Emilie. 1992. Activation of macrophages and cytotoxic cells during cytomegalovirus pneumonia complicating lung transplantations. Am. Rev. Respir. Dis. 145:1178-1184.

149. Ikeda, S., J. Neyts, M. Matsuura, M. Kiso, A. Hasegawa, C. Nishimura, and E De-Clercq. 1993. Protective activity of lipid $A$ analogue GLA-60 against murine cytomegalovirus infection in mice. $J$. Med. Virol. 40:222-227.

150. Isom, H. C., J. Mummaw, and J. W. Kreider. 1983. Malignant transformation of guinea pig cells after exposure to ultraviolet-irradiated guinea pig cytomegalovirus. Virology. 126:693-700.

151. Jacobson, M. A. 1992. Review of the toxicities of foscarnet. J Acquir. Immune. Defic. Syndr. 5 (Suppl. 1):S11-\$17.

152. Jacobson, M. A., P. de-Miranda, D. M. Cederberg, T. Burnette, E. Cobb, H. R. Brodie, and J. Mills. 1987. Human pharmacokinetics and tolerance of oral ganciclovir. Antimicrob. Agents. Chenother. 31:1251-1254.

153. Jahn, G., B. C. Scholl, B. Traupe, and B. Fleckenstein. 1987. The two major structural phosphoproteins (pp65 and pp 150) of human cytomegalovirus and their antigenic properties. J. Gen. Virol. 68 (Pt 5):1327-1337.

154. Jesionek, and Kiolemenoglou. 1904. Ueber einen Befund von protozoënartigen Gebilden ün den Organen eines hereditär-luetischen Fötus. München Med Wochenschr. 43:1905-1907.

155. Jordan, M. C., and C. Pomeroy. 1991. Latent CMV infection in the mouse. Transplant Proc. 23 (Suppl 3): 17-21. 


\section{Chapler I}

156. Jordan, M. C., J. L. Takagi, and J.G. \$teveris. 1982. Activation of latent murine cytomegalovirus in vivo and in vitro: a pathogenetic role for acute infection. In Infect. Dis. 145:699-705.

157. Kalayjian, R. C., M. L. Cohen, R. A. Bonomo, and T. P. Flanigan. 1993. Cytomegalowirus ventriculoencephalitis in AIDS. A syndrome with distinct clinical and pathologic features. Medicine. (Balimore). 72:67-77.

158. Kane, R. C., W. E. Roussedi, G. R. Noble, G. E. Tegtmeier, H. Wulf, H. Brooks, "T. D. Y. Chin, and W. L. Bayer. 1975. Cytomegalowirus infection in a volunteer blood donor population. Infect. Immunity. 11:7!19-723.

159. Kari, B., and R. Gehrz. 1992. A human cytomegalovirus glycoprotein complex designated $\mathrm{gC}-\mathrm{I}$ is a major heparin-binding component of the envelope. J Firol. 66:1761-1764.

160. Keay, S., and B. Baldwin. 1991. Anti-idiotype antibodies that mimic gp 86 of human cytomegalovirus inhibit viral fusion but not attachment. $J$. Virol, 65:5124-5128.

161. Keay, S., and B. Baldwin. 1992. The human fibroblast receptor for $\mathrm{gp} 86$ of human cytomegalovirus is a phosphorylated glycoprotein. J. Virol. 66:4834-4838.

162. Keil, G. M. M. R. Fibi, and U. H. Koszinowski. 1985, Characterization of the major immediate-early polypeptides encoded by murine cytomegalovirus. If. Virol. 54:422-428.

163. Kilpatrick, B. A., and B. S. Huang. 1977. Human cytomegalovirus genome:partial denaturation map and organization of genome sequences. J. Virol. 24:261-276.

164. Kim, Y. S., and H. Hollander. 1993. Polyradiculopathy due to cytomegalovirus: report of two cases in which improvement occurred after prolonged therapy and review of the literature. Clin. Infecr. Dis. 17:32-37.

165. Klemola, E. 1973. Cytomegalovirus infection in previously healthy adults. Ann. Intern. Med. $79: 267-268$.

166. Klemola, E, and L. Kaarriainen. 1965. Cytomegalovirus as a possible cause of a disease resembling infectious mononucleosis. Brit. Med. J. 2:1099-1102.

167. Knox, G. E., R. F. Pass, D. W. Reynolds, S. Stagno, and C. A. Alford. 1979. Comparative prevalence of subclinical cytomegalovirus and herpes simplex virus infections in the genital and urinary tracts of low-income, urban women. J. Inf. Dis. 140:419-422.

168. Knox, K. K., and D. R. Carrigan. 1994. Disseminated active HHV -6 infections in patients with AIDS [see comments]. Lancer 343:577-578.

169. Koskinen, P., K. Lemström, C. Bruggeman, I. Lautenschlager, and P. Hayry. 1994. Acute cytomegalovirus infection induces a subendothelial inflammation (endothelialitis) in the allograft vascular wall. A possible linkage with enhanced allograft arteriosclerosis, Am. J. Pathol. 144:41-50.

170. Krech, U. 1973. Complement-fixing antibodies against cytomegalovirus in different parts of the world. Bull. W. H. O. 49:103-106.

171. Kunder, S. C., L. Wu, and P. S. Morahan. 1993. Protection against murine cytomegalovirus infection in aged mice and mice with severe combined immunodeficiency disease with the biological response modifiers polyribosinic-polycytidylic acid stabilized with L-lysine and carboxymethylcellulose, maleic anhydride diwinyl ether and colony stimulating factor 1. Antiviral Res. $211233-245$.

172. Kuppermann, B. D., J. L. Quiceno, M. Flores-Aguilar, J. D. Connor, E. V. Capparelli, C. H. Sherwood, and W. R. Freeman. 1993. Intravitreal ganciclovir concentration after intravenous administration in AIDS patients with cytomegalovirus retinitis: implications for therapy.J. Infect. Dis. 168:1506-1509.

173. Kurihara, I., Y. Uchida, and K. Hayashi. 1983. [Studies of ocular cytonegalovirus infection. II. Detection of latent virus]. Nippon. Ganka. Gakkas. Zasshi. 87:861-865.

174. Lalezari, J. P., W. L. Drew, E. Glutzer, D. Miner, S. Safrin, W. F. Owen Jr, J. M. Davidson, P. E. Fisher, and H. S. Jaffe. 1994. Treatment with intravenous (S)-1-[3-hydroxy-2-(phosphonyl- 
methoxy)propyl]-cytosine of acyclovir-resistant mucocutaneous infection with herpes simplex virus in a patient with AIDS. J. Infect. Dis: 170:570-572.

175. Landini, M. P., and S. Michelson. 1988. Human cytomegalovirus proteins Prog. Med Virol. $35: 152-185$.

176. Landini, M. P., G. Mirolo, P. Coppolecchia, M. C. Re, and M. La-Placa. 1986. Serum antibodies to individual cytomegalowirus structural polypeptides in renal transplant recipients during viral infection. Microbiol. Immunol 30:683-695.

177. Landini, M. P., M. C. Re, G. Mirolo, B. Baldassarri, and M. La-Placa. 1985. Human immune response to cytomegalovirus structural polypeptides studied by immunoblotting. $J$. Med. Firol. 17:303-311.

178. Landini, M. P., A. Ripalti, K. Sra, and P. Pouletty. 1991. Human cytomegalovirus structural proteins: immune reaction against ppl50 synthetic peptides. J. Clin. Microbiol. 29:1868-1872.

179. Landini, M. P., B. Severi, G. Furlini, and L. Badiali-De-Giorgi. 1987. Human cytomegalovirus structural components: intracellular and intraviral localization of $\mathrm{p} 28$ and p65-69 by immunoelectron microscopy. Wirus. Res. 8:15-23.

180. Laskin, O. L., D. M. Cederberg, J. Mills, L. J. Eron, D. Mildvan, and S. A. Spector. 1987. Ganciclovir for the treatment and suppression of serious infections caused by cytomegalovirus. $A m$. $J . M e d$. $83: 2011-207$

181. Lawson, C. M., H. L. O'Donoghne, and W. D. Reed. 1992. Mouse cytomegalovirus infection induces antibodies which cross-react with virus and cardiac myosin: a model for the study of molecular mimicry in the pathogenesis of viral myocarditis. Immsnology. 75:513-519.

182. Lemström, K. B., P. T. Aho, C. A. Bruggeman, and P. J. Hayyry. 1994. Cytomegalovirus infection enharces mRNA expression of platelet-derived growth factor-BB and transforming growth factor-_ 1 in rat aortic allografts. Possible role for cytomegalovirus-enhanced graft arteriosclerosis. Arterioscler: Thromb. $14: 2043-2052$.

183. Lemström, K. B., J. H. Bruning, C. A. Bruggeman, I. T. Lautenschlager, and P. J. Hdiyry. 1993. Cytomegalovirus infection enhances smooth muscle cell proliferation and intimal thickening of rat aortic allografts. J. Clin. Invest. 92:549-558.

184. Lemström, K., M. Persoons, C. Bruggeman, J. Ustinow, l. Lautenschlager, and P. Hayry. $\llbracket 993$. Cytomegalovirus infection enhances allograft arteriosclerosis in the rat. Transploni. Proc. 25:14061407.

185. Lemström, K. B., J. H. Bruning, C. A. Bruggeman, P. K. Koskinen, P. T. Aho, S. Yillmaz, I. T. Lautenschlager, and P. J. Hayry. 1994. Cytomegalovirus infection-enhanced allograft arteriosclerosis is prevented by DHPG prophylaxis in the rat. Circulation. 90:1969-1978.

186. Lemström, K., J. Bruning, P. Koskinen, C. Bruggeman, I. Lautenschlager, and P. Hayry. 1994. Triple-drug immunosuppression significantly reduces chronic rejection in noninfected and RCMV. infected rats. Transplant. Proc. 26:1727-1728.

187. Li, F, G. Grauls, M. Yin, and C. Bruggeman. 1995. Initial endothelial injury and cytomegalovirus. infection accelerate the development of allograft arteriosclerosis. Transplant. Proc. In Press.

188. Li, S. B., Z. H. Yang, J. S. Feng, C. K. Fong, H. L. Lucia, and G. D. Hsiung. 1990. Activity of (S)-1-(3-laydroxy-2-phosplonylmethoxypropyl)cytosine (HPMPC) against guinea pig cytomegalovirus infection in cultured cells and in guinea pigs. Antiviral. Res. 13:237-252.

189. Lipschütz. 1921. Untersuchungen über die Ätiologie der Krankheiten der Herpesgruppe (Herpes zoster, Herpes genitalis, Herpes febrillis). Arch. Dermatol u. Syph :428-482.

190. Liu, Y. N., A. Klaus, B. Kari, M. F. Stinski, J. Eckhardt, and R. C. Gehrz 1991. The N-terminal 513 amino acids of the envelope glycoprotein gB of human cytomegallowirus stimulates both B-and $\mathrm{T}-\mathrm{call}$ immune responses in humans. J. Virol. 65:1644-1648. 
191. Ljungman, P., D. Engethard, H. Link, P. Biron, L. Brandt, S. Brunet, C. Cordonnier, L. Debusscher, A. de-Laurenzi, H. J. Kolla, C. Messina, A. C. Newland, H. G. Prentice, C. Richard, T. Ruutu, H. Tilg, and L. Verdonck. 1992. Treatment of interstitial pneumonitis due to cytomegalowirus with ganciclovir and intravenous immune globulin: experience of European Bone Marrow Transplant Group. Clin Infect. Dis. 14:831-835.

192. Lucia, H. L., B. P. Griffith, and G. D. Hsilung. 1985. Lymphadenopathy during cytomegalovirus-induced mononucleosis in guinea pigs. Arch. Pathol Lab. Med. 109:1019-1023.

193. Lusisier, G. 1975. Cerebrall calcification, cytomegalowirus infection. Am. J. Pathol. 80:555-558.

19\%. Luther, P.D., P. C. Bradley, and D. A. Haig. 1971. The isolation and characterization of a herpesvirus from calf kidney cell culturesi. Res. Vet. Sei. 12:496-498.

195. Manischewitz, J. E., and G. V. J. Quinnan. 1980. Antivirus antibody-dependent cell-mediated cytotoxicity during murine cytomegalovirus infection. Infec. Immunity. 29:1050-1054.

196. Martin , J. C., C. A. Dvorak, D. F. Smee, T. R. Matthews, and J. P. Verheyden. 1983. 9-[(1,3-Dihydroxy-2-propoxy)methyl]guanine: a new potent and selective antiherpes agent. $J$. Med. Chem. 26:759-761.

197. Matthews, T, and R. Boehme. 1988. Antiviral activity and mechanism of action of ganciclovir. Rev. Infect. Dis. 10 (Suppl. 3):S490-S494.

198. Mayo, D. R., J. A. Armstrong, and M. Ho. 1977. Reactivation of murine cytonegalowirus by cyclophosphamide. Nature 267:721-723.

199. Mayo, D., J. A. Armstrong, and M. Ho. 1978. Activation of latent murine cytomegalovirus infection: cocultivation, cell transfer, and the effect of immunosuppression. $J$. Infect. Dis. 138:890-896.

200. Meijer, H., P. H. Dormans, J. L. Geelen, and C. P. van-Boven. 1984. Rat cytomegalovirus: studies on the viral genome and the proteins of virions and nucleocapsids. J. Gen. Virol. 65 (Pt 4):681-695.

201. Meijer, H., J.C. Dreesen, and C.P. Van-Boven. 1986. Molecular cloning and restriction endonuclease mapping of the rat cytomegalovirus genome. J. Gen. Virol. 67 (Pt 7):1327-1342.

202. Melnick, J. L., E. Adam, and M. E. DeBakey. 1990. Possible role of cytomegalovirus in atherogenesis. Jama. 263:2204-2207.

203. Merigan, T. C., D. G. Renlund, S. Keay, M. R. Bristow, V. Starnes, J. B. O'Connell, S. Resta, D. Dunn, P. Gamberg, R. M. Ratkovec, W. E. Richenbacher, R. C. Millar, C. DuMond, b DeAmond, V. Sullivan. T. Cheney, W. Buhles, and E. B. Stinson. 1992. A controlled trial of ganciclovir to prevent cytomegalovirus disease after heart transplantation. N. Engl. J. Med. 326:1182-1186.

204. Meyer, H., A. T. Bankier, M. P. Landini, C. M. Brown, B. G. Barrell, B. Ruger, and M. Mach. 1988. Identification and procaryotic expression of the gene coding for the highly immunogenic 28-kilodalton structural phosphoprotein (pp28) of human cytomegalovirus. J. Yirol. 62:2243-2250.

205. Meyers, J. D., J. Leszezymski, J. A. Zaia, N. Flournoy, B. Newton, D. R. Snydman, G. G. Wright, M. J. Levin, and E. D. Thomas. 1983. Prevention of cytomegalovirus infection by cytomegalovirus immune globulin after marrow transplantation. Am Intern. Med. 98:442-446.

206. Meyers, J. D., E. C. Reed, D. H. Shepp, M. Thornquist, P. S. Dandliker, C. A. Vicary, N. Flournoy, L. E. Kirk, J. H. Kersey, E. D. Thomas, et al. 1988. Acyclovir for prevention of cytomegalovirus infection and disease after allogeneic marrow transplantation. N. Engl. J. Med. 318:70-75.

207. Milburn, H. J., R. M. Du-Bois, H. G. Prentice, and L. W. Poulter. 1990. Pneumonitis in bone marrow transplant teeipients results from a local immune response. Clin. Exp. Immunol. 81:232-237.

208. Miller, R. G., J. R. Storey, and C. M. Greco. 1990. Ganciclowir in the treatment of progressive AIDS-related polyradiculopathy. Neurology. 40:569-574.

209. Mills, J., and L. Corey. 1986. Antiviral therapy: new directions for clinical application and research. Elsevier Science Publishing, inc., New York. 195-203 pp. 
210. Mocarski, E. S., M. Bonyhadi, S. Salimi, J. M. McCune, and H. Kaneshima. 1993. Hunan cytomegalovirus in a SCID hu mouse: thymic epithelial cells are prominent targets of viral replication. Proc. Natl Acad Sci. U.S. A. 90:104*108.

211. Morse, G. D., M. J. Shelton, and A. M. O'Donnell. 1993. Comparative pharmacokinetics of antivital nucleoside analogues. Clin. Pharmacokinet. 24:101-123.

212. Naesens, L.* J. Neyts, J. Balzarini, A. Holy, I. Rosenberg, and E. De-Clercq. 1993, Efficacy of oral 9-(2-phosphonylmethoxyethyl)-2,6-diaminopurine (PME DAP) in the treatment of retrovirus and cytomegalowirus infections in mice. J. Med. Virol 39:167-172.

213. Neyts, J., J. Balzarini, L. Naesens, and E. De-Clercq. 1992. Efficacy of (S)-1-(3-hydroxy-2-phosphony /methoxypropyl)cytosine and 9-(1,3-dihydroxy-2-propoxymethyl)guanine for the treatment of murine cytomegalovirus infection in severe combined immunodeficiency mice. J. Med. Virol. 37:67-71.

214. Neyts, J., and E. De-Clercq. 1994. Mechanism of action of acyclic nucleoside phosphonates against herpes virus replication. Biochem. Pharmacol. 47:39-41.

215. Neyts, J., R. Snoeek, D. Schols, J. Balzarini, and E. De-Clereq. 1990. Selective inhibition of human cytomegalovirus DNA synthesis by (S)-1-(3-hydroxy-2-phosphonylmethoxypropylloytosine [(S)HPMPC] and 9-(1,3-dihydroxy-2-propoxymethyl)guanine (DHPG). Virology: 179:41-50.

216. Neyts, J., R. Snoeck, D. Schols, J. Balzarini, J. D. Esko, A. Van-Schepdael, and E. De-Clercq. 1992. Sulfated polymers inhibit the interaction of human cytomegalovirus with cell surface heparan sulfate. Virology: 189:48-58.

217. Neyts, $J_{0,} H$. Sobis, R. Snoeck, M. Vandeputte, and E. De-Clercq. 1993. Efficacy of (S)-1-(3-hydroxy-2-phosphonylmethoxypropyl)-cytosine and 9-(1,3-dihydroxy-2-propoxymethyl)-guanine in the treatment of intracerebral murine cytomegalovirus infections in immunocompetent and immunodeficient mice. Eur. J. Clin. Microbiol. Infect. Dis. 12:269-279.

218. Nuovo, M. A., G. J. Nuovo, J. Becker, F. Gallery, P. Delwenne, and P. B. Kane. 1993. Correlation of viral infection, histology, and mortality in immunocompromised patients with pneumonia. Analysis by in situ hybridization and the polymerase chain reaction. Diagn. Mol. Pathol 2:200-209.

219. Olver, S. D., P. Price, and G. R. Shellam. 1994. Cytomegalovirus hepatitis: characterization of the inflammatory infiltrate in resistant and susceptible mice. Clin. Exp. Immunot 98:375-381.

220. Osorio, F. A., D. L. Rock, and D. E. Reed. 1985. Studies on the pathogenesis of a bovine cytomegalo-like virus in an experimental host. J. Gen. Virol. 66 (Pt 9):1941-1951.

221. Pass, R. F., K. B. Fowler, and S. Boppana. 1991. Clinical importance of cytomegallowirus infection: An owerview. In Progress in cytomegalowirus research. M. P. Landini, editors. Elsevier Science Publishers B.V., Amsterdam. 3-10.

222. Pass, R. F., C. Hutto, R. Ricks, and $G$. A. Cloud. 1986. Increased rate of cytomegalovirus infection among parents of children attending day-care centers. N. Engl. J. Med 314:1414-1418.

223. Pass, R. F., S. Stagno, G. J. Myers, and C. A. Alford. 1980. Outcome of symptomatic congenital cytomegalowirus infection: results of long-term longitudinal follow-up. Pediatrics. 66:758-762.

224. Pereira, L., M. Hoffman, and N. Cremer. 1982. Electrophoretic analysis of polypeptides immune precipitated from cytomegalovirus-infected cell extracts by human sera. Infec. Immumity. 36:933-942.

225. Pereira, $\mathbb{L} .$, M. Hoffman, D. Gallo, and N. Cremer. 1982. Monoclonal antibodies to human cytomegalovirus:three surface membrane proteins with unique immunological and electrophoretic properties specify cross-reactiwe determinants. Infec. Immunity. 36:924-932.

226. Pereira, L., M. Hoffman, M. Tatsumo, and D. Dondero. 1984. Polymorphism of human cytomegalovirus glycoproteins characterized by monoclonal antibodies. Virology 139:73-86. 
227. Pereira, L., D. Navarro, and G. Jahn 1993. Proteins of human cytomegallovirus that elicit humoral immunity. In Molecular aspects of human cytomegalowirus diseases. Y. Becker, G. Darai, and E.-S. Huang, editors. Springer Verlag, Berlin. 437-464.

228. Pereitu, L., S. Stagno, M. Hoffman, and J. E. Volanakis. 1983. Cytomegalovirus-infected cell polypeptides immune-precipitated by sera from children with congenital and perinatal infections. Imfect. Immun. 39:100-108.

229. Persoons, M. C., M. J. Daemen, J. H. Bruning, and C. A. Bruggeman. 1994. Active cytomegallovirus infection of arterial smooth muscle cells in immunocompromised rats. A clue to herpesvirus-associated atherogenesis? Circ. Res. 75:214-220.

230. Peterson, P. K., H. H. Balfour Jr, D. S. Fryd, R. Ferguson, R. Kronenberg, and R. L. Simmons. 1983. Risk factors in the development of cytomegalovirus-related pneumonia in renal transplant recipients. J. Infect. Dis. 148:1121.

231. Plachter, B., S. Kllages, S. Hagelmann, W. Britt, M. P. Landini, and G. Jahn. 1990. Procaryotic expression of phosphorylated tegument protein pp65 of human cytomegalovirus and application of recombinant peptides for immunoblot analyses. $J$. Clin. Micrabiol. 28:1229-1235.

232. Plachter, B., L. Wieczorek, B. C. Scholl, R. Ziegelmaier, and G. Jahn. 1992. Detection of cytonegalovirus antibodies by an enzyme-linked immunosorbent assay using recombinant polypeptides of the large phosphorylated tegument protein pp 150. J. Clin. Microbiol. 30:201-206.

233. Plummer, G., P. L. Coleman, and D. Henson. 1972. Chronic infection of the rabbit central nerwous system by a slowly growing equine herpeswirus. Infect. Immun 5:172-175.

234. Quinnan, G.V., and J. E. Manischewitz. 1979. The role of natural killer cells and antibody-dependent cell-mediated cytotoxicity during murine cytomegalovirus infection. J. Exp. Med. 150:1549-1554.

235. Quinnan, G. V., Jr, N. Kirmani, A. H. Rook, J. F. Manischewitz, L. Jackson, G. Moreschi, G. W. Santos, R. Saral, and W. H. Burns. 1982. Cytotoxic t cells in cytomegalovirus infection: HLA-restricted T-lymphocyte and non-T-lymphocyte cytotoxic responses correlate with recovery from cytomegalovirus infection in bone-marrow-transplant recipients. N. Engl. J. Med. 307:7-13.

236. Rabkin, C. S.y A. Hatzakis, P. D. Griffiths, D. Pillay, M. V. Ragni, M. W. Hilgartner, and J. J. Goedert. 1993. Cytomegalovirus infection and risk of AIDS in human immunodeficiency virus-infected hemophilia patients. Nationai Cancer Institute Multicenter Hemophilia Cobort Study Group. $d$. Infect. Dis. 168:1260-1263.

237. Rager-Zisman, B., Y. Segew, S. Blagerman, A. Palmon, S. Tel-Or, M. Pecht, N. Trainin, and Y. Burstein. 1993. Thymic humoral factor, THF-gamma 2, emhances immunotherapy of murine cytomegalovirus (MCMV) infection by both CD4t and CD8+ immune T cells. Immunol Lett. 39:23-31.

238. Rager-Zisman, B., F. Zuckerman, D. Benharroch, M. Pecht, Y. Burstein, and N. Trainin. 1990. Therapy of a fatal murine cytomegalovirus infection with thym ic humoral factor (THF-ganma 2) treated inmune spleen cells. Clin. Exp. Intmunol. 79:246-252.

239. Rasimussen, L., M. Nelson, M. Neff, and T. C. Merigan Jr. 1988. Characterization of two different human cytomegalovirus glycoproteins which are targets for virus neutralizing antibody. Firology. $163: 308 \sim 318$

240. Reddehase, M. J., and U. H. Koszinowski. 1984. Significance of herpesvirus immediate early gene expression in cellular immunity to cytomegalovirus infection. Nature. 312:369-371.

241. Reddehase, M. J., W. Mutter, K. Münch, H. J. Bühring, and U. H. Koszinowski. 1987. CD8-positive $T$ lymphocytes specific for murine cytomegalovirus immediate-early antigens mediate protective immunity. J. Virol. 61:3102-3108.

242. Reddehase, M. J., F. Weiland, K. Münch, S. Jonjic, A. Lüske, and U. H. Koszinowski. 1985. Interstitial murine cytomegalovirus pneumonia after irradiation: characterization of cells that limit viral replication during established infection of the lungs. $f$. Wirol. 55:264-273. 
243. Reed, E. C., R. A. Bowden, P. S. Dandliker, K. E. Liflieby, and J. D. Meyers. 1988 . Treatment of cytomegalovirus pneumonia with ganciclowir and intravenous cytomegalowirus immunoglobulin in patients with bone marrow transplants. Amn. Interk. Med. 109:783-788.

244. Reed, E. C., J. L. Wolford, K. J. Kopecky, K. E. Lilleby, P. S. Dandliker, J. L. Todaro, G. B. McDonald, and J. D. Meyers. 1990. Ganciclovir for the treatrnent of cytomegalovirus gastroenteritis in bone marrow transplant patients. A randomized, placebo-controlled trial. Am. Iwern. Med. 11 2:505-510.

245. Rubbert. 1904. Ueber protozoenartige Zellen in der Niere eines syphilitischen Neugeborenen und in der Parotis won Kindern. Centraibl. Allgem. Pathol. w. Pathal. Anat 23-945-948.

246. Riddell, S. R., M. Rabin, A. P. Geballe, W. J. Britt, and P. D. Green berg. 1991 . Class I MHC-restricted cytatoxic $T$ lymphocyte recognition of cells infected with human cytomegalowirus does not require endogenous viral gene expression. J. Immumol. 146:2795-2804.

247. R.jnaldo, C. R., Jr., M. J. Levin, and W. P. Carney. 1979. Interactions of Iymplnocytes with cytomegalovirus. In: Virus-lymphocyte interactions.: Implications for disease. M. R. Proffitt, editors. Elsevier Science Publishers B.V., Amsterdam. 267-282.

248. Roby, C., and W. Gibson. 1986. Characterization of phosphoproteins and protein kinase activity of virions, noninfectious enveloped particles, and dense bodies of human cytonegalovirus. J. Virol. 59:714-727.

249. Roullet, E, V. Assuerus, J. Gozlan, A. Ropert, G. Said, M. Baudrimont, M. el-Amrani, C. Jaconnet, C. Duwivier, G. Gonzales-Canali, et a1. 1994. Cytomegalovirus multifocal neuropathy in AIDS: analysis of 15 consecutive cases. Neurology 44:2174-2182.

250. Rowe, W. P., J. W. Hartley, S. Waterman, H. C. Turner, and R. J. Huebner. 1956. Cytopathogenic agent resembling human salivary gland virus recovered from tissue cultures of human adenoids. Proc. Soc. Exp. Biol. Med 92:418-424.

251. Rubenn $n_{n}$ F. L., and M. L. Nguyen. 1991. Viral pneumonitis. Clin. Chest. Med. 12:223-235.

252. Rubin, R. H. 1990. Impact of cytomegalovirus infection on organ transplant recipients. Rev. Infect. Dis. 12 (Suppl. 7):S754-S766.

253. Rubin, R. H. 1991. Preemptive therapy in immunocompromised hosts [editorial; comment]. N. Engl. J. Med 324:1057-1059.

254. Rubin, R. H., P. Lynch, M. S. Pasternack, D. Schoenfeld, and D. N. Medearis Jr. 1989. Combined antibody and ganciclovir treatment of murine cytomegalovirus-infected normal and immunosuppressed BALB/c mice. Antimicrob. Agents. Chemother. 33:1975-1979.

255. Rudolph, S. A., J. E. Kuhn, K. Korn, R. W. Braun, and G. Jahn. 1990. Prokaryotic expression of the major capsid protein of human cytomegalovirus and antigenic cross-reactions with herpes simplex virus type 1.J. Gen. Virol. 71 (Pt 9):2023-2031.

256. Sandford, G. R., K. Ho, and W. H. Burns. 1993. Characterization of the major locus of immediateearly genes of rat cytomegalowirus. $J$. Virol 67:4093-4103.

257. Schmidt, G. M., D. A. Horak, J. C. Niland, S. R. Duncan, S. J. Forman, J. A. Zaia, and City of Hope-Stanford-Syntex CMV Study Group. 1991. A randomized, controlled triall of prophylactic ganciclovir for cytomegalovirus pulmomary infection in recipients of allogeneic bone marrow transplants. N. Engl. J. Med. 324:1005-1011.

258. Scholl, B. C., J. Von-Hintzenstern, B. Borisch, B. Traupe, M. Broker, and G. Jahn. 1988. Prokaryotic expression of immunogenic polypeptides of the large phosphoprotein (ppl 50 ) of human cytomegalovirus. J. Gen. Virol. 69 (P1 6):1195-1204.

259. Schooley, R. T. 1990. Cytomegalovirus in the setting of infection with human immunodeficiency virus [see comments]. Rev. Infect. Dis. 12 (Suppl. 7):\$811-\$819. 
260. Schwariz, J. N. C. A. Daniels, J. C. Shivers, and G. K. Klintworth. 1974. Experimental cytomegam lovirus ophthalmitis. Am. N. Parhol. 77:477-492.

261. Schwarz, M. 1., and T. E. King. 1993. Interstitial lung disease. Mosby year Book, London. 821 pp.

262. Selgrade, M.K., and J. E. Osborn. 1974. Role of macrophages in resistance to murine cytomegalowirus. Infeer. Irwan: 10:13:33-1390.

263. Shanley, J. D. 1990. In vivo administration of monoclonal antibody to the NK 1.1 antigen of natural killer cells: effect on acute murine cytomegallovirus infection. J. Med. Virol. 30.58-60.

264. Shanley, J. D. 1991 . Murine models of cytomegalovirus-associated pneumonitis. Transplant. Proc. 23 (Suppl 3):12-6, discussion 16.

265. Shanley, J. D., L. Biczak, and S. J. Forman. 1993. Acute murime cytomegalovirus infection induces lethal hepatitis. In Infect Dis: 167:264-269.

266. Shanley, J. D., M. C. Jordan, and J. G. Stevens. 1981 . Modification by adoptive immunity of murine cytomegalowirus infection. . Imf. Dis. 143:231-237.

267. Shanley, J. D., and E. L. Pesanti. 1985. The relation of viral replication to interstitial pneumonitis in murine cytomegalovirus lung infection. J. Infect. Dis. 151:454-458.

268. Shanley, J. D., E. L. Pesanti, and K. M. Nugent. 1982. The pathogenesis of pneumonitis due to murine cytomegalovirus. J. Inf. Dis. 146:388-396.

269. Shanley, J. D., C. S. Via, S. O. Sharrow, and G. M. Shearer 1987 . Interstitial pneumonitis during murine cytomegalovirus infection and graft-versus-host reaction. Characterization of bronchoalveolar lavage cells. Transplantation. 44:658-662.

270. Shellam, G. R., J. E. Allan, J. M. Papadimitriou, and G. J. Bancroft. 1981. Increased susceptibility to cytomegalovirus infection in beige mutant mice. Proc. Nanl. Acad. Sci. U. S. A. 78:5104-5108.

271. Shellam, G. R., J. P. Flexman, H. E. Farrell, and J. M. Papadimitriou. 1985. The genetic background modulates the effect of the beige gene on susceptibility to cytomegalowirus infection in mice. Scand. J. Immunol. 22:147-155.

272. Shepp, D. H., P. S. Dandliker, P. de-Miranda, T. C. Burnette, D. M. Cederberg, L. E. Kirk, and J. D. Meyers. 1985. Activity of 9-[2-hydroxy-1-(hydroxymethyl)ethoxymethyl]guanine in the treatment of cytomegalovirus pneumonia. Ann. Intern. Med. 103:368-373.

273. Sidwell, R. W., D. F. Smee, R. P. Warren, J. H. Huffman, B. J. Gilbert, R. A. Burger, and F. C. Pearson. 1993. Murine cytomegalovirus-inhibitory effects of Imu Vert. Antiviral. Res. 20:279-292.

274. Smee, D. F., J. L. Morris, J. A. Leonhardt, J. R. Mead, A. Holy, and R. W. Sidwell. 1992. Treatment of murine cytomegalovirus infections in severe combined immunodeficient mice with ganciclovir, (S) 4 - [3-hydroxy-2-(phosphonylmethoxy)propyl]cytosine, interferon, and bropirimine. Antimicrob. Agens. Chemother. $36: 1837-1842$.

275. Smee, D. F., S. T. Sugiyama, and E. J. Reist. 1994. Nucleotide analogs related to acyclovir and ganciclovir are effective against murine cytomegalovirus infections in $B A L B / C$ and severe combined immunodeficient mice. Antimicrob. Agents. Chemother. 38:2165-2168.

276. Smith, M. G. 1954. Propagation of salivary gland virus of the mouse in tissue cultures. Proc. Soc. Exp. Biol. Med 86:435 440.

277. Smith, M. G. 1956. Propagation in tissue cultures of a cytopathogenic virus from human salivary gland virus (SGV) disease. Proc. Soc. Exp. Biol. Med. 92:424-430.

278. Snoeck, R., G. Andrei, M. Gerard, A. Silverman, A. Hedderman, J. Balzarini, C. Sadzot-Delvaux, G. Tricot, N. Clumeck, and E. De-Clercq. 1994. Successful treatment of progressive mucocutaneous infection due to acyclovir- and foscarnet-resistant herpes simplex virus with (S)-1-(3-hydroxy-2phosphonylmethoxypropyl)cytosine (HPMPC). Clin Infect. Dis. 18:570-578.

279. Snydman, D. R. 1988. Ganciclovir therapy for cytomegalovirus disease associated with renal transplants. Rev. Infect. Dis. 10 (Suppl. 3):5554-\$562. 
280. Snydman, D. R. 1990. Cytomegalovirts immunoglobulins in the prevention and treatment of cytomegalovirus disease: Rev. Infect. Dis. 12 (Suppl. 7):5839-S848.

281. Snydman, D. R., B. G. Werner, B. Heinze-Lacey, V. P. Berardi, N. L. Tilney, R. L. Kinkmen, E. L. Milford, S. I. Cho, H. L. Bush Jr., A. S. Levey, T. B. Strom, C. B. Carpenter, R. H. Levey, W. E. Harmon, C. E. Zimmerman, M. E. Shapiro, T. Steinman, F. LoGerfo, B. Idelson, G. P. J. Schroter, M. J. Levin, J. McIver, J. Leszczynski, and O. F. Grady. 1987. Use of cytomegalowirus immune globulin to prevent cytomegalowirus disease in renal-transplant recipients. N. Engl. J. Med 3.17:10491054.

282. Span, A. H. M., P. M. Frederik, G. Grauls, C. P. A. van Boven, and C. A. Bruggeman. 1993. CMV induced vascular injury: an electron-microscopic study in the rat. In vivo 7:567-574.

283. Span, A. H., G. Grauls, F. Bosman, C. P. van-Boven, and C. A. Bruggeman. 1992 Cytomegalovirus infection induces vascular injury in the rat. Atherosclerosis. 93:41-52.

284. Speir, E., R. Modali, E. S. Huang, M. B. Leon, F. Shawl, T. Finkel, and S. E. Epstein. 1994. Potential role of human cytomegalovirus and $p 53$ interaction in coronary restenosis [see comments]. Science. 265:391-394.

285. Staczek, J. 1990. Animal cytomegaloviruses. Microbiol. Rev. 54:247-265.

286. Stagno, S., D. W. Reynolds, R. F. Pass, and C. A. Alford. 1980. Breast milk and the risk of cytomegalovirus infection. N. Engl. J. Med. 302:1073-1074.

287. Stern, H., and S. D. Elek. 1965. The incidence of infection with cytomegallowirus in a normall population. J. Hyg. 63:79-87.

288. Sterner, G., B. O. Agell, B. Wahren, and A. Espmark. 1970. Acquired cytomegalovirus infection in older children and adults. Scand. J. Infec. Dis. 2:95-103.

289. Stratta, R. J. 1993. Clinical patterns and treatment of cytomegalovirus infection after solid-organ transplantation. Transplant. Proc. 25 (Suppl 4):15-21.

290. Stratta, R. J., M. S. Shaefer, K. A. Cushing, R. S. Markin, R. P. Wood, A. N. Langnas, E. C. Reed, G. L. Woods, J. P. Donovan, T. J. Pillen, et al. 1991. Successful prophylaxis of cytomegalowirus disease after primary CMV exposure in liver transplant recipients. Transplantation. 51:90-97.

291. Strauss, M, and B. P. Griffith. 1991. Guinea pig model of transplacental congenital cytomegaloviral infection with analysis for labyrinthitis. Am. $J$. Orol. 12:97-100.

292. Tokumoto, J. I., and H. Hollander. 1993. Cytomegalovirus polyradiculopathy caused by a ganciclovir-resistant strain. Clim. Infect. Dis. 17:854-856.

293. Urban, M., T. Winkler, M. P. Landini, W. Britt, and M. Mach. 1994. Epitope-specific distribution of IgG subclasses against antigenic domains on glycoproteins of human cytomegalovirus. I. Imfect. Dis. 169:83-90.

294. Ustinow, J., C. Bruggeman, P. Hayry, and I. Lautenschlager. 1994. Cytomegalovirus-induced class Il expression in rat kidney. Trawsplant. Proc. 26:1729.

295. Ustinow, J., R. Loginow, C. Bruggeman, J. Suni, P. Hayry, and I. Latutenschlager. 1994. CMV-induced class II antigen expression in various rat organs. Transpl. Int. 7:302-308.

296. Ustinow, I., R. Loginow, C. Bruggeman, P. van-der-Meide, P. Hatyry, and I. Lautenschllager. 1993. Direct induction of class IJ antigens by cytonegalovirus in rat heart endothelial cells. Tramsplant. Proc. 25 (Pt 2):1143-1144.

297. Ustinov, J. A., R. J. Loginov, C. A. Bruggeman, P. H. van-der-Meide, P. J. Hayry, and I. "T. Lautenschlager. 1993. Cytomegalovirus induces class II expression in rat heart endothelial cells. $J$. Heart. Lung. Transplant 12:644-651.

298. Utz, U., W. Britt, L. Vugler, and M. Mach. 1989. Identification of a neutralizing epitope on glycoprotein gp58 of human cytomegalovirus. J. Wirol. 63:1995-2001. 
296. Van-Dam-Mieras, M. C. C. A. Bruggeman, A. D. Muller, W. H. Debie, and R. F. Zwaall. 1987. lnduction of endothelial cell procoagulant activity by cytomegalovirus infection. Thromb. Res $47: 69-75$.

300. Via, C. S. J. D. Sthatiley, and G. M. Shearer. 1990. Synergistic effect of murine cytomegallovirus on the induction of acute graft-vs-host disease involving MHC class I differences only. Analysis of in vitro T cell function. J. Immumol 145:3283-3289.

301. von-Bueltzingsloewen, A, P. Bordigoni, F, Witz, M. C. Bene, C. Schmitt, B. Lacour, and D. Sommelet. 1993. Prophylactic use of ganciclovir for allogeneic bone marrow transplant recipients. Bone. Marrow. Transplant: $12: 197-202$.

302. Webster, A. 1991. Cytomegalovirus as a possible cofactor in HIV disease progression. $J$. Acquir. Irtmune. Defic. Symdr. 4 Suppl 1:S47-S52.

303. Weller, T. H. 1971. The cytomegaloviruses: ubiquitous agents with protean clinical manifestations. II. N. Engl J. Med: 285:267-274.

304. Weller T. H., I. C. Macauley, J. M. Craig, and P. Wirth. 1957. Isolation of intranuclear inclusion producing agents from infants with illnesses resembling cytomegallic inclusion disease. Proc. Soc. Exp. Biol. Med. 94:4-12.

305. Welsh, R. M., J. O. Brubaker, M. Vargas-Contes, and C. L. O'Donnell. 1991. Natural killer (NK) cell response to virus infections in mice with severe combined immunodeficiency. The stimulation of $N K$ cells and the NK cell-dependent control of virus infections occur independently of $\mathrm{T}$ and $\mathrm{B}$ cell function. J. Exp. Med 173:1053-1063.

306. Wentworth, B. B., and E. R. Alexander. 1971. Seroepidemiology of infections due to members of the herpesvirus group. Amer. J. Epidemiol. 94:496-507.

307. Weston, K. 1988. An enhancer element in the short unique region of human cytomegalovirus regulates the production of a group of abundant immediate early transcripts. Virology, 162:406-416.

308. Wiesner, R. H., E. Marin, M. K. Porayko, J. L. Steers, R. A. Krom, and C. V. Paya. 1993. Advances in the diagnosis, treatment, and prevention of cytomegalovirus infections after liver transplantation. Gastroenterol. Clin. North Am. 22:351-366.

309. Williamson, W. D., M. M. Desmond, N. LaFevers, L. H. Taber, F. I. Catlin, and T. G. Weaver, 1982. Symptomatic congenital cytomegalovirus (Disorders of language, learning, and hyaring). Amer. J. Dis. Child. 136:902-905.

310. Winston, D. J., W. G. Ho, K. Bartoni, G. N. Holland, R. T. Mitsuyasu, R. P. Gale, R. W. Busuttil, and R. E. Champlin. 1988. Ganciclovir therapy for cytomegalovirus infections in recipients of bone

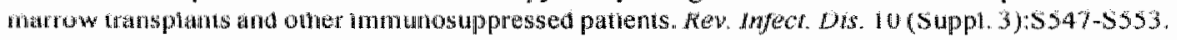

311. Winston, D. J., W. G. Ho, C. L. Howell, M. J. Miller, R. Mickey, W. J. Martin, C. H. Lin, and R. P. Gale. 1980. Cytomegalovirus infections associated with leukocyte transfusions. Ann Inter. Med. $93.67 \llbracket-675$.

312. Winston, D. J., W. G. Ho, C. H. Lin, K. Bartoni, M. D. Budinger, R. P. Gale, and R. E. Champlin. 1987. Intravenous immune globulin for prevention of cytomegalovirus infection and interstitial pneumonia after bone marrow transplantation. Anm. Intern. Med. 106:12-18.

313. Woolf, N. K. 1991. Guinea pig model of congenital CMV-induced hearing loss" a review. Transplant. Proc. 23 (Suppl 3):32-4, discussion 34

314. Wyatt, J. P., J. Saxton, R. S. Lee, and H. Pinkerton. 1950. Generalized cytomegalic inclusion disease. J. Pediat 36:271-294.

315. Yatgyu, K., G. Steinhoff, A. M. Duijwestijn, C. A. Bruggeman, H. Matsumoto, and P. J. van-BredaVriesman. 1992. Reactivation of rat cytomegalovirus in lung allografts: an experimental and immunohistochemical study in rats. J. Heart. Lung. Transplant. 11:1031-1040. 
316. Yagyu, K., P. J. vam-Breda-Vriestian, A. M. Duijvestijn, C. A. Bruggeman, and G. Steinhoff. 1993. Reactivation of eytomegalovirus with acute rejection and cytomegalowirus infection with obliterative bronchiolitis in rat lung allografts. Transplan. Proc. 25:1152-1154.

317. Yamamoto, N., Y. Yamada, T. Daikoku, Y. Nishiyama, Y. Tsutsui, N. Shimada and K. Takahashi. 1990. Antiviral effect of oxetanocin $G$ against guinea pig cytomegalovirus infeetion in vitro and in vivo. J Antibiot. Tokyo: 43:1573-1578.

318. Yang, Z. H.s. S. Klein, and G. D. Hsiung. 1991. Comparative effects of two acycleonucleoside derivatives on ultrastructure and replication of guinea pig cytonegalovirus in cultured cells. Intervrology $32: 297-307$.

319. Yeager, A. S., F. C. Grumet, E. B. Hafleigh, A. M. Arvin, J. S. Bradley, and C. G. Prober. 1981. Prevention of transfusion-acquired cytomegalovirus infections in newborn infants, J. Pediat. 98:281= 287.

320. Yoser, S. L., D. J. Forster, and N. A. Rao. 1993. Systemic wiral infections and their retinal and choroidal manifestations. Surw. Ophthalmol. 37:313-352.

321. Zaia J. A. 1990. Viral infections associated with bone marrow transplantation. Hematol. Oncol Clin. North. Am. 4:603-623. 


\section{2}

\section{An animal model for therapeutic intervention studies of CMV infection in the immunocompromised host}

\section{Summary}

An experimental rat model to study acute cytomegalovirus infections is described. Eightweek-old male Brown Norway rats, immunosuppressed by total body irradiation, were infected with rat cytomegalovirus (RCMV). The effects of infection were determined by survival rates and the presence of virus or viral components in different organs was assayed by plaque test, immunoperoxidase staining, dot-blot DNA hybridization and in situ DNA hybridization. At day 10 post infection nearly $90 \%$ of the amimals had died. Spleen, liver and bone marrow were heavily infected. Interstitial pneumonia was observed. Pathological findings strongly resembled the full scale of lesions in human CMV infections. Anti-RCMV hyper immune serum was effective against mortality from RCMV infection and viral spread to lungs and liver was prevented. This model is appropriate for studies on the pathogenesis and antiviral therapy of CMV infections in the immunocompromised host. 


\section{Introduction}

The ubiquity of cytomegalovirus (CMV) infections in man is now well established. Although most primary infections are asymptomatic and become latent, it has become clear that in immunosuppressed patients, including cancer patients receiving chemotherapy, AIDS patients, and transplant recipients, CMV is a frequent pathogen and an important cause of morbidity and mortality. After renal transplantation most patients develop symptomatic CMV disease due to either primary or secondlary infections (16).

Clinically these patients present a variety of symptoms associated with virus-induced lesions in almost every organ system. Ultimately, in these severely infected patients CMV is responsible for $15-20 \%$ mortality. However, in transplant recipients anti-CMV immune globulin dramatically decreases morbidity and mortality $(2 \mathbb{1}, 30)$.

To further elucidate the pathogenesis of CMV infections, a homologous virus host system in a readily available laboratory animal is of primary importance (2). In addition, an animal model to study the effect of therapeutic intervention is still needed. In 1982 rat cytomegalovirus (RCMV) was isolated from will rats (7). CMV infections in the immunocompetent rat are asymptomatic, as is generally assumed to be the case in man. After primary infections the virus remains in a latent state in the host. Immunosuppression leads to reactivation of the latent virus. Passive transfer of RCMV infections by renal transplants in rats occurs with high incidence (9). However, this model does not reflect the course of a severe CMV infection. Therefore, in an attempt to mimic the conditions in which CMV infections in their most threatening form can be studied, we developed a model of RCMV infection in the immunocompromised rat. In this model the pathology of the acute viral infection in different organ systems is described and the effect of anti-CMV immune globulin treatment was studied to evaluate the model for therapeutic intervention studies.

\section{Materials and methods}

\section{Animals}

Inbred specific pathogen-free (SPF) male Brown Norway (BN) rats were used at eight weeks of age with a total body weight ranging from 140 to $180 \mathrm{~g}$. These rats were bred at the Department of Experimental Animal Service at the University of Limburg, Biomedical Centre, Maastricht, The Netherlands.

\section{Immunosuppression}

A 5 Gray (Gy) dose of total body X-irradiation (TBI) was administered one day before infection as described earlier (8) or otherwise as indicated. 


\section{Virus and infection}

The RCMV stock consisted of a pool of salivary glands from acutely infected laboratory rats (4). The salivary glands were homogenized and injected by the intraperitoneal route as described before (7).

The animals received $10^{5}$ plaque-forming units (PFU) of virus or otherwise as indicated.

\section{Design of the experiments}

Groups consisting of a minimum of 5 immunocompromised rats were infected with RCMV one day after TBL. The rats were maintained in separate cages for a maximum of three weeks post infection (p.i.). From rats which had died in the first three weeks after infection, material from the organs was collected for determination of infectious RCMV, RCMV-DNA and viral antigens. Bone marrow and brain tissue were obtained for DNA and antigen determination only. Surviving rats were sacrificed after three weeks and samples of the same organs were taken.

The following control groups were used:

a. non-irradiated and non-infected group (group A), an irradiated (5 Gy) and non-infected group (group B), and an infected ( $10^{5}$ PFU RCMV) and non-irradiated group (group C). Half of each control group was killed 8 days p.i. and the other half was killed at three weeks p.i. To study the effect of anti-RCMV hyper immune serum (HIS) animals were treated in one single dose as described below. The effect was measured by survival rates and virus organ titres 8 days pi.

\section{Histology}

Samples of organs were fixed in paraformaldehyde-lysine-periodate (PLP) and embedded in paraffin using routine histopathological procedures.

Seriall sections of $5 \mu \mathrm{m}$ thickness were cut for routine haematoxylin-eosin staining as well as immunoperoxidase for RCMV antigens and in situ hybridization for RCMV-DNA detection.

\section{Monoclonal antibodies}

Mouse monoclonal antibodies (McAbs) against RCMV-induced antigens were produced and characterized in our laboratories as described before (10). In this study two McAbs, which specifically reacted in immunoprecipitation with polypeptides major abundant in virions: McAb 35 directed against a $29 \mathrm{kDa}$ polypeptide of RCMV gives a diffuse immunofluorescence signal in the cytoplasm of RCMV-infected cells. McAb 8, directed against 41, 46, and $91 \mathrm{kDa}$ polypeptides of RCMV (19) gives an immunofluorescence signal in the nucleus of infected cells. None of the $\mathrm{McAb}$ reacted with non-infected cells. 


\section{Chapter 2}

\section{Immunohistochemistry}

Tissue sections $(5 \mu \mathrm{m})$ were mounted on glass slides, deparaffinized and blocked for endogenous peroxidase by incubation in $100 \%$ methanol containing $0.3 \% \mathrm{H}_{2} \mathrm{O}_{2}$ for $30 \mathrm{~min}$. The sections were further refydrated and washed with phosphate buffered saline (PBS) and preincubated with PBS containing $2 \%$ bovine serum albumin (BSA) for $30 \mathrm{~min}$, followed by incubation with a mixture of mouse McAbs 8 and 35 for 1 h. The sections were washed in PBS for $5 \mathrm{~min}$, followed by incubation with biotinylated, affinity-purified, sheep anti-mouse Ig (Amersham Nederland B.V., Houten, The Netherlands) 1:200 in PBS containing 2\% BSA for $1 \mathrm{~h}$, washed again in PBS and incubated with biotin-streptavidin-HRP-complex (Amersham), 1.400 in PBS containing 2\% BSA for 30 min. After washing in PBS the sections were incubated for $10 \mathrm{~min}$ in diaminobenzidine (DAB) substrate $0.05 \%$ in Tris-HCL buffer $\mathrm{pH} 7.4$ containing $0.002 \% \mathrm{H}_{2} \mathrm{O}_{2}$. The colour reaction was stopped by washing in PBS. After counter staining during $30 \mathrm{sec}$ in haematoxylin the slides were dehydrated and mounted in Entellan (Merck, Darmstadt, Federal Republic of Germany).

The specificity of the monoclonal antibodies was evaluated with an anti-human CMV McAb and with organ sections obtained from non-infected control rats.

Only McAbs 8 and 35 showed reactivity with organ sections obtained from RCMV-infected animals.

\section{Probe DNA for in situ and dot blot hybridization}

The construction and analysis of recombinant plasmids of RCMV-DNA were performed as described previously (20).

The Xbal fragments $C, D$, and $E$ were cloned in the pSP62 plasmid and transfected in Escherichia coli strain HB101 rec A: Isolation of plasmids was performed according to Birnboim et al. (3).

Plasmids were cleaved by Xbal and subjected to 0.7\% agarose electrophoresis.

Xbal fragment $C, D$, and $E$ were then cut out of the gel and the DNA was recovered using the Biotrap apparatus (Schleicher and Schull, Dassel, Federal Republic of Germany) as described by Góbel et al. (13).

The fragments, accounting for $23.7 \%$ of the entire RCMV genome, were mixed in equimolar amounts and labelled with biotin 11-dUTP (Sigma, St. Louis, USA.) using the random primed labelling kit (Boehringer, Almere, The Netherlands).

The speciticity of the biotinylated DNA probes was evaluated in non-infected rat embryonal fibroblasts (REF). REF infected with RCMV and organ samples using both dot-blotting and in situ hybridization also were performed without DNA probes to evaluate non-specific reactions. 


\section{In situ hybridization}

This techmique was performed as described earlier (15). In short, the paraffin-embedded tissue sections were mounted on chrome-alum gelatin coated, glutaraldebyde-activated slides. Sections were dewaxed and aldehyde groups were inactivated by incubation in $1 \%$ ammonium chloride solution in PBS. Proteolytic digestion was carried out with proteinase $\mathrm{K}$. After washing in glycine PBS buffer the slides were dehydrated in a series of graded alcohols. Tissue sections were then overlaid with hybridization mixture containing the DNA probe, covered. with a silicon coated coverslip and sealed to create a constant micro-environment.

Cellular and probe DNA were denatured simultaneously by heating the sections to $80^{\circ} \mathrm{C}$ on a beating block of $100^{\circ} \mathrm{C}$ for $30 \mathrm{sec}$ followed by immediate immersion in ice water. Subsequently, the hybridization was carried out overnight at $42^{\circ} \mathrm{C}$. Visualization was performed with the BLUE-gene ${ }^{\mathrm{TM}}$ kit (Bethesda Research Laboratories, BRL, Faithersburg; USA.). RCMV-infected REF and RCMV-infected organ samples showed hybridization reactivity whereas mock-infected $R E F$ and non-infected organ samples did not show any reactivity at all. HCMV and plasmid probes never showed hybridization.

\section{Dot blot hybridization}

Extraction of cellular DNA was performed as previously described (28). Before spotting on filters the DNA was denatured by incubation for $1 \mathrm{~h}$ at $65^{\circ} \mathrm{C}$ in $0.35 \mathrm{M} \mathrm{NaOH}$, followed by adjusting the $\mathrm{pH}$ to 7.0 and ionic strength to $6 \mathrm{x}$ sodium chloride sodium citrate buffer (SSC). Thereafter the resulting solution was serially diluted in $6 \mathrm{x}$ SSC in order to obtain a final amount of $2.5,1.25$, and $0.6 \mu \mathrm{g} / \mathrm{DNA}$ spot. Using a manifold this DNA was spotted on nitrocellulose filters type BA85 (Schleicher and Schull). To bind DNA to the nitrocellulose, the filters were placed at $80^{\circ} \mathrm{C}$ for $1 \mathrm{~h}$.

Prehybridization and hybridization were performed as described earlier (15). To detect probe target hybrids, filters were incubated in a streptavidin-alkaline phosphatase conjugate (BRL). After extensive washings $5 \mathrm{~mm}$ spots were punched out and placed in a 96 wells microtiter flat-bottom plate, filled with $200 \mu \mathrm{pNPP}(6.6 \mathrm{nM} / \mathrm{l}$ in $0.05 \mathrm{M}$ carbonate buffer $\mathrm{pH} 9.8$ containing $0.001 \mathrm{M} \mathrm{MgCl} 2$.

After incubation at room temperature for 2-4 h the reaction was stopped with $1 / 3$ volume of $5 \mathrm{~N} \mathrm{NaOH}$ and the nitrocellulose discs were removed. Absorbance was measured in a multichannel spectrophotometer (Multiskan, Amstelstad, Zwanenburg, The Netherlands) at $405 \mathrm{~nm}$. The assay was evaluated with DNA extracted from RCMV-and mock-infected REF. Only DNA extracted from RCMV-infected REF showed hybridization reactivity. HCMV and plasmid probes did not show hybridization.

\section{Virus assay}

A quantitative assay for RCMV was performed as described previously (4). Brielly, samples of spleen, kidney, liver, and lungs were homogenized within $12 \mathrm{~h}$ after the death of the animal 
and diluted 1:10 (w/v) in Eagle's Minimal Essential Medium (MEM). Ten-fold dilutions were cultured on REF and the amount of virus was expressed as the number of PFU per gram tissue.

\section{Preparation of hyper immune serum (HIS)}

HIS was obtained from immunized SPF male BN rats as follows:

eight-week-old animals were infected intrademally below the popliteal fossa of the posterior legs with $10^{5} \mathrm{PFU}$ RCMV, emulsified in Freund's complete adjuvants (FCA). After 4 and 7 weeks the procedure was repeated with RCMV in FCA. Ten days after the last administration of RCMV serum was obtained from the abdominal aorta of the animals. Negative control serum was prepared by administration of a non-infected sallivary gland suspension. To test the concentration of neutralizing antibodies in the HIS the plaque-reduction assay was used (24). In short, 2-fold dilutions of heat-inactivated serum were incubated with 300 PFU RCMV in basal medium Eagle's (BME) $+2 \%$ new-born calf serum (NCS) for 1 h at $37^{\circ} \mathrm{C}$. These mixtures were absorbed on a REF monolayer in a 24-wells plate for $\rrbracket$ h at $37^{\circ} \mathrm{C}$. After mixtures were removed the monolayers were overlaid with a BME-agarose mixture. After 7 days the monolayers were fixed in formalin $1.8 \%$ in PBS, stained with methylene blue and the plaque reduction titre $\left(\mathrm{ID}_{\mathrm{s}_{0}}\right)$ was calculated.

\section{Administration of HIS to RCMV-infected rats}

To determine the possible efficacy of HIS in modulating the effect of RCMV infection $1 \mathrm{ml}$ of 2-fold dilutions of HIS with a neutralization titre of 160 was injected intravenously into animals that were subsequently challenged with a variable irradiation dose (5 Gy or 6 Gy) and with a variable amount of infectious virus $\left(10^{4} \mathrm{PFU}\right.$ to $10^{6} \mathrm{PFU}$ RCMV). The day of HIS administration varied in different experiments as defined.

In the control groups the lethally infected rats received negative control serum. In all experiments groups of 10 rats were used.

\section{Statistical analyses}

For statistical analyses the Mann-Whitney test and Fisher's exact test were used. For comparison of the survival curves the generalized Willcoxon test by Gehan was used $(12,14)$. $P$. Values $<0.05$ were considered statistical significant, unless indicated otherwise.

\section{Results}

\section{Effect of immunosuppression and RCMV infection on the mortality}

To study the effect of RCMV infection on the mortality of immunosuppressed rats (receiving $5 \mathrm{GY} T \mathrm{~T}$ I) the animals were infected with $10^{2}, 10^{3}, 10^{4}$, or $10^{5}$ PFU RCMV. The animals were 


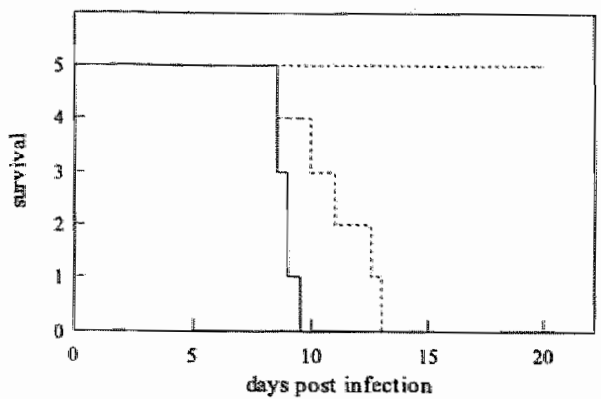

Figure 1. Survival curves of four different groups of immunocompromised rats $(n=5)$ after intraperitoneal inoculation with $10^{5} \mathrm{PFU}(-), 10^{4} \mathrm{PFU}(--)$, and $10^{3}$ ot $10^{2}$ PFU ( .....) RCMV and of control groups $A, B$, and $C(\cdots)$. These results are representative for 3 separate experiments.

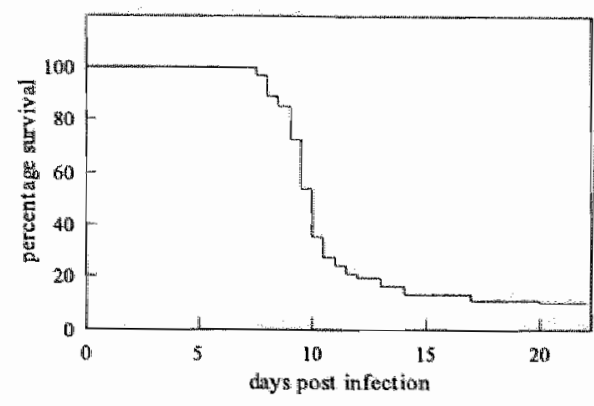

Figure 2. Overall survival rates from $S$ separate $e x$ periments on 62 consecutive rats receiving $10^{5} \mathrm{PFU}$ RCMV ji.p. and 5 Gy TBI. The control group $A, B$, and C showed no mortality $(P<0,0001)$.

observed twice daily for a period of three weeks. In figure 1 the survival of these infected rats is shown. All animals receiving $10^{4}$ or $10^{5}$ PFU RCMV died between day 7 and day 13 . In contrast, the animals receiving $10^{2}$ or $10^{3} \mathrm{PFU}$ virus and the control rats all survived the three week period.

To determine the effect of TBI on the course of RCMV infection 4 groups of 5 rats received $5,4,3$, or 2 Gy one day prior to infection with $10^{5}$ PFU RCMV. In the 5 Gy TBI group all animals died within 12 days p.i. In the other groups no mortality was observed during the three weeks post infection. Repetitions of this experiment indicated that 5 Gy TBI is the critical dose needed to result in a lethal infection.

Subsequently, we calculated the survival rates from 5 separate experiments with rats, receiving 5 Gy TBI and $10^{5}$ PFU RCMV. As shown in figure 2 the overall survival rate declines following a sigmoidal curve to $8 \%$ at the end of the experiment. Control rats receiving $5 \mathrm{~Gy}$ TBI without infection (group B) all survived during the experimental period $(P<0.0001)$.

\section{Infectious virus, viral genome and antigen in the organs}

The presence of infectious virus in the organs of the RCMV-infected rats was studied using the plaque assay. In these experiments rats receiving $5 \mathrm{~Gy}$ TBI were infected with either $10^{2}$, $10^{3}, 10^{4}$, or $10^{5}$ PFU RCMV (5 rats per group). Controls consisted of group A, B, and C (see Materials and methods). The animals were killed three weeks p.i. All rats receiving $10^{4}$ and $10^{5}$ PFU died from infection. They were autopsied within 24 hours post mortem and plaque assays were performed. These results are shown in figure 3.

In all organs of rats receiving $10^{4}$ or $10^{5}$ PFU RCMV infectious virus could be detected. Virus yields were higher $(P<0.05)$ in spleen and liver than in kidneys and lungs in both groups (figure 3). The virus yields detected in each organ were not significantly different between 


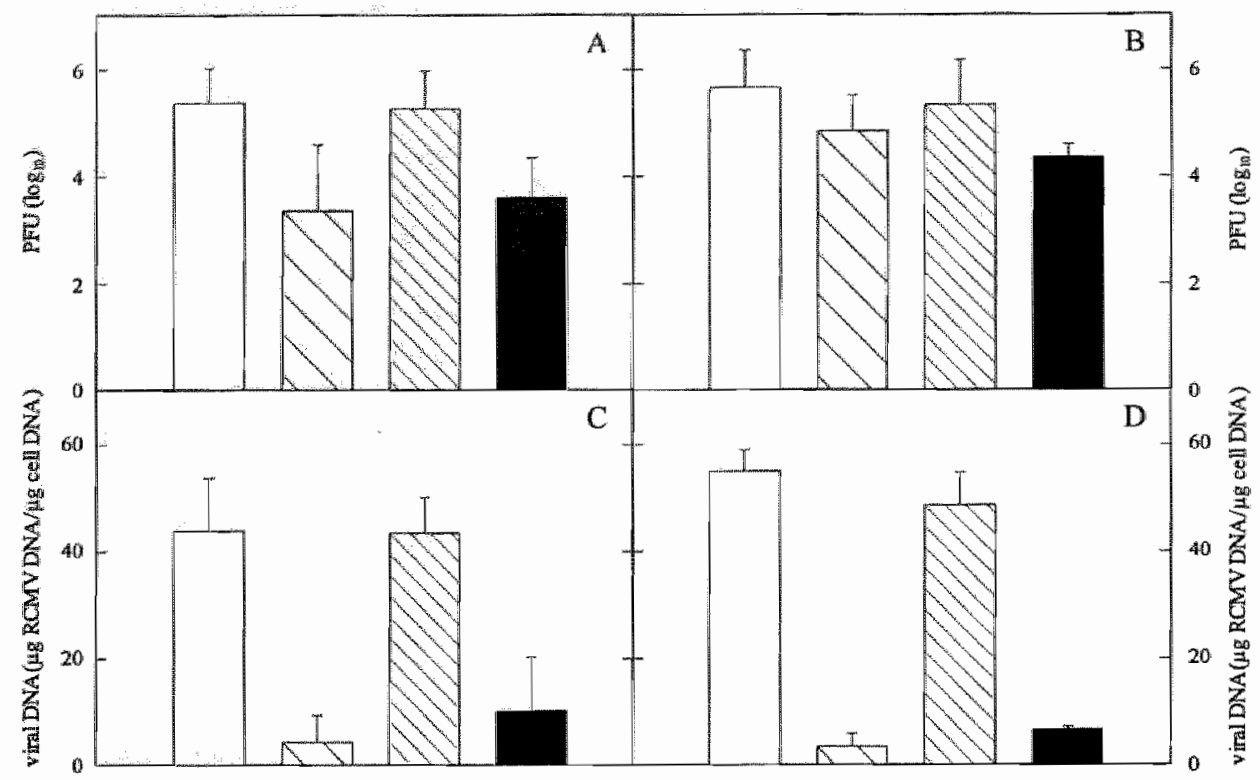

Figure 3. Yield of infectious virus and viral DNA in spleen $(\square)$, kidney ( $\square)$, liver $(\triangle)$ and lungs ( $\square$ ) of rats, challenged with RCMV. Amount of plaque forming units in the group infected with $10^{4}$ PFU RCMV (A) and in the group infected with $10^{\mathfrak{f}}$ PFU RCMV (B); amount of viral DNA, detected by dot blot hylaridization in the group infected with either $10^{4}$ PFU RCMV (C) or $10^{5}$ PFU RCMV (D). These data are representative for 2 separate experiments. Each bar represents the mean value of 5 rats the standard deviation.

these two groups $(P>0.05)$. In the groups receiving $10^{3} \mathrm{PFU} R \mathrm{RMV}$, the results were negative (data not shown). Although occasionally, a very low level of virus (about 70 PFU per gram tissue) was found in the spleen. In the control groups, including the infected non-irradiated group $C$, no wirus could be detected at day 10 and 21 p.i.

The amount of viral DNA as determined by dot blot analysis in various organs is shown in figure $3 \mathrm{C}$ and $\mathrm{D}$ for the groups which received $10^{4}$ and $10^{5} \mathrm{PFU}$ virus.

In all organs tested viral DNA was detectable. The amount of virall DNA was significantly higher $(P<0.05)$ in the spleen and liver than in the kidneys and lungs. Significant differences were not found between the groups which received $10^{4}$ or $10^{5}$ PFU RCMV $(P>0.05)$ (figure 3).

In the groups receiving $10^{2}$ or $10^{3} \mathrm{PFU}$ RCMV (data not shown) no or very little viral DNA could be detected (in the order of $1 \mathrm{ng}$ RCMV DNA/ $\mu \mathrm{g}$ cellular DNA).

No viral DNA could be detected in all control groups.

In situ hybridization showed that in the organs of the animals infected with $10^{5}$ PFU RCMV, cells containing viral DNA were present (table 1).

In spleen and liver a significantly higher percentage of cells contained viral DNA than in kidneys and lungs $\left(P^{p}<0.05\right)$. 
Table 1. Presence of viral antigens and viral DNA ill the organs of RCMV-infected rats".

\begin{tabular}{lll}
\hline Organ & $\begin{array}{l}\text { Viral antigens } \\
\text { positive }(\%) \pm s d\end{array}$ & $\begin{array}{l}\text { Viral DNA } \\
\text { positive }(\%) \pm s d\end{array}$ \\
\hline Spleen & $69 \pm 21$ & $49 \pm 28$ \\
Kidneys & $<1$ & $<1$ \\
Liver & $27 \pm 15$ & $29 \pm 17$ \\
Lungs & $3.6 \pm 3$ & $<1$ \\
\hline
\end{tabular}

The results are expressed as the percentage of positive cells of at least 10 slides \pm standard deviation. Data represent the results of 3 separate experiments.

${ }^{2}$ The rats were infected with $10^{5} \mathrm{PFU}$ RCMV and received 5 Gy TBL.

${ }^{b}$ Viral antigens were detected by the immunoperoxidase technique.

"Viral DNA was detected by the in situ DNA hybridization test.

In the control groups $(\mathrm{A}, \mathrm{B}$, or $\mathrm{C})$ reactive cells were not detected.

The results of the experiments for the detection of viral antigens by immunoperoxidase staining are also shown in table 1.

The proportion of positive cells in the organs is quite similar to the results obtained with the in situ hybridization.

\section{Pathology}

\section{Macroscopic examination}

After an incubation period of 7 to 14 days the RCMV infection became symptomatic. The rats showed symptoms, such as bruslay hairs, ocular discharges and impaired reactivity to exogenous stimuli. Symptomatic disease progressed within 48 hours into death. Since most animals died between day 8 and day 14 (figure 2) organ pathology was documented in a transversal study in experimental and control $(A, B$, and $C)$ rats on day 10 p.i. Fifty percent of the animals died between day 8 and 10 and the remaining $50 \%$ of the animals which survived till the 10 th day of infection were then sacrificed. Twenty percent of the rats showed disease and $30 \%$ of the rats had no symptoms of infection. All control groups remained asymptomatic. To prove that morbidity and mortality is related to the occurrence of CMV viremia and the presence of extensive organ damage, the spleen, kidneys, liver and Iungs were harvested and used for plaque assay (determination of infectious virus) and immunoperoxidase staining (detection of viral antigens). The results are shown in table 2. In asymptomatic animals neither viral DNA nor viral antigens could be detected in any organ tested but the spleen. In the group of animals which died before day 10 infectious virus and viral antigens were detectable in all organs studied. In the animals alive on day 10 p.i. and showing signs of infection small amounts of virus and viral antigens were detectable in the organs. 
Table 2. Presence of whus and vilal antigens in the RCMV-infected rats

Transwersal sidudy.

\begin{tabular}{|c|c|c|c|c|c|c|}
\hline \multirow[t]{2}{*}{ Organ } & \multicolumn{3}{|c|}{ Deatechon of virat amigens } & \multicolumn{3}{|c|}{ Detection of infectious virus ${ }^{c}$} \\
\hline & $\begin{array}{l}\text { "spontante } \\
\text { ously" } \\
\text { dead before } \\
\text { day } 10 \\
50 \%\end{array}$ & $\begin{array}{l}\text { with } \\
\text { symitoms } \\
\text { at day } 10 \\
20 \%\end{array}$ & $\begin{array}{l}\text { symptom- } \\
\text { free } \\
\text { at day } 10 \\
30 \%\end{array}$ & $\begin{array}{l}\text { "spontane- } \\
\text { ously" } \\
\text { dead before } \\
\text { day } 10\end{array}$ & $\begin{array}{l}\text { with } \\
\text { symptoms } \\
\text { atl day } 10\end{array}$ & $\begin{array}{l}\text { symptom- } \\
\text { free } \\
\text { at day } 10\end{array}$ \\
\hline Spleery & 70 & 50 & 1 & 5.8 & 3.6 & 1.7 \\
\hline Kidneys & $<1$ & nog. & meg. & 4.9 & 3.1 & neg. \\
\hline luiver & 60 & $20^{\circ}$ & neg. & 5.3 & 3.6 & neg. \\
\hline Cungss & 17 & $<1$ & neg. & 4,4 & 18 & meg. \\
\hline
\end{tabular}

The rats were infected with $10^{5}$ WNOU RCMW and received 5 Gy TBI.

16. Wiral antigens are detected by the immunoperoxidase technique. The results are expressed as the percentage of cells giving a positive staining.

"Infectious wirus is detected by the plaque assay and is expressed as logro PFU RCMV/g organ. The results shown represent the means of 2 experiments.

\section{Histopathology}

The characteristic histopathological changes in the organs of lethally infected animals can be summarized as follows:

- Liver: The parenchyma showed patchy necrosis (figure 4a). Scattered throughout the parenchyma mononuclear cells were seen. Cholestasis was not apparent. Numerous hepatocytes showed characteristic inclusion bodies. By immunohistochemistry these cells as well as many Kupffer cells contained viral antigens (figure $4 \mathrm{~b}$ ) and by in situ DNA hybridization: viral DNA (figure 4c).

- Spleen: The periarteriolar lymphocyte sheaths had almost completely disappeared. Sinuses were massively congested with macrophages with nuclear inclusions and cytoplasmic hemosiderin pigment. These cells contained viral antigens (figure $4 \mathrm{~d}$ ) as well as viral DNA.

- Lungs: In rats inoculated with a high input of virus the interstitium showed congestion with haemorrhages and infilttrating macrophages. Furthermore, numerous alveolar macrophages and erythrocytes were present. The macrophages and occasional pneumocytes were immunoreactive for CMV (figure 4e).

* Kidneys: In the kidneys only the glomeruli showed discrete abnormalities. The mesangial cells were swollen and displayed characteristic nuclear inclusions. These cells contained viral antigens (figure $4 \mathrm{f}$ ) as well as viral DNA. Occasional vascular endothelial cells displayed similar findings. Also numerous viral antigen and DNA bearing mesenchymal cells occurred in the renal capsulle.

- Bone marrow: In bone marrow smears intensely immunoreactive mononuclear cells could be detected (figure $4 \mathrm{~g}$ ). 

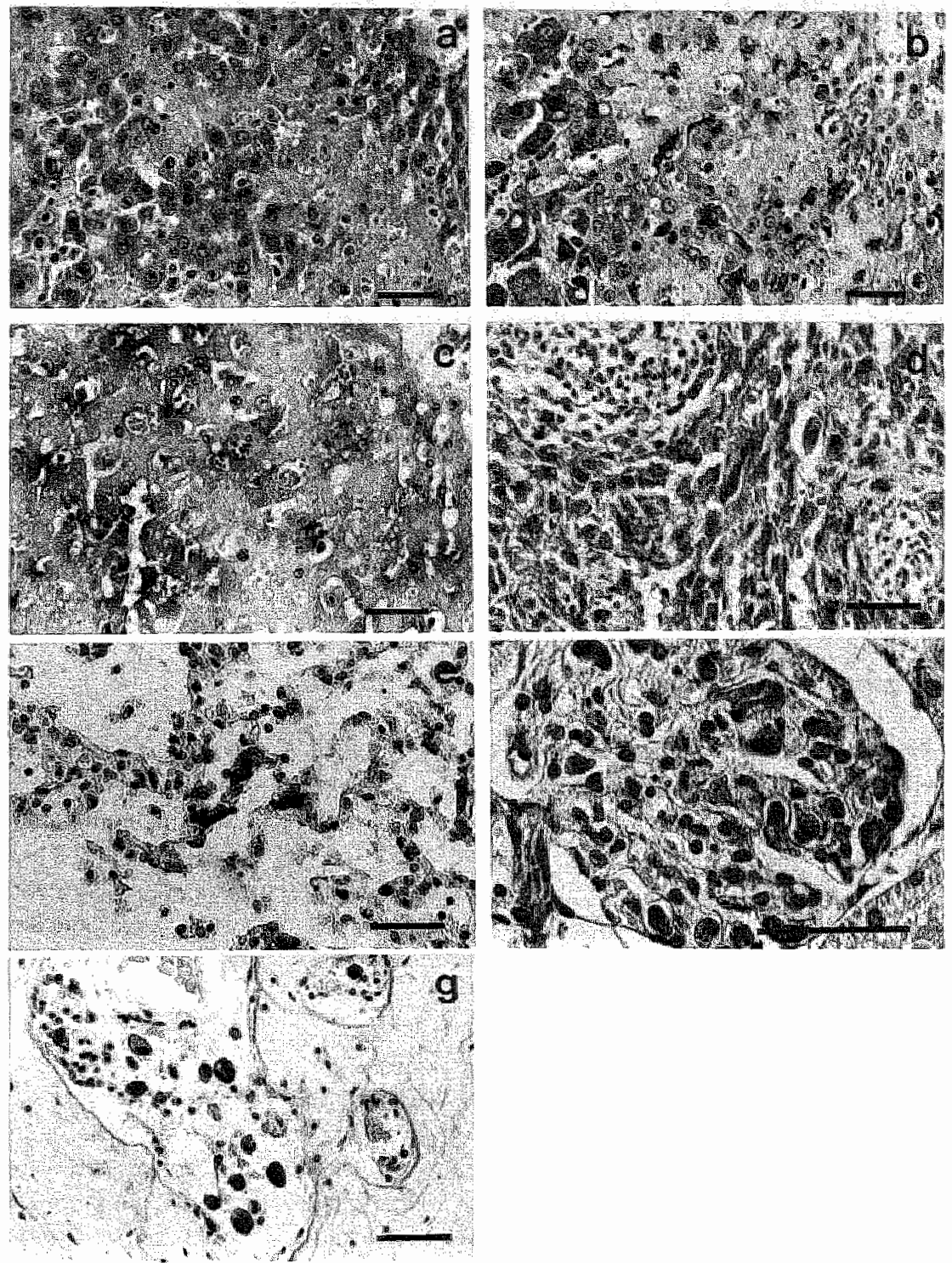

Figure 4. Demonstration of liver damage in serial sections by HE staining (a), immurnoperoxidase staining (IPOX) (b) and ISH (c). Note the patchy necrosis and numerous hepatocytes with CMV inclusion bodies which stained positively by IPOX and ISH. IPOX of the spleen (d) shows massive congestion of siruses with inmunoreactive macrophages. IPOX of lungs (e) shows immunoreactive macrophages and pneumocytes. IPOX of the kidneys (f) shows a glomerulus with immunoreactive swollen mesangial cells and characteristic nuclear inclusions. IPOX of the bone marrow (g) shows intensive reactivity of mononuclear cells. Bar: $5 \mu \mathrm{m}$. 
Tabie 3. The presence of infectious virus in several organs of RCMV-infected inmunocompromised rats ${ }^{z}$ on several stages post infection.

\begin{tabular}{lllll}
\hline Days p.i & Organ & & & \\
\cline { 2 - 5 } & Spleen & Kidney & Liver & Lungs \\
\hline 1 & neg. & neg. & neg. & neg. \\
3 & 2.3 & neg. & neg. & neg. \\
7 & $3.9 \pm 1.2$ & $3.2 \pm 0.6$ & $2.8 \pm 0.8$ & $3.2 \pm 0.7$ \\
\hline
\end{tabular}

${ }^{a}$ Each group consisted of 5 rats. The animals received 5 Gy TBI.

${ }^{b}$ neg. $<22$. The virus titre is expressed as log:0 PFU RCMV per gram organ, mean \pm standard deviation.

- Brain: Histologically the cerebrum and cerebellum did not show signs of infection. Scattered immunoreactive cells were found intravascularly in one rat only.

- Eye.: In the retina no histological abnormalities were found. By immunoperoxidase and in situ hybridization procedures, exclusively blood-borne cells were reactive. Furthermore, immunoreactive cells were visualized in the lacrimal glands.

\section{Viral spread to several organs early in infection}

Irradiated RCMV-infected rats were killed on day 1, 3, and 7 post-infection. Material from several organs was collected to perform plaque assays and histopathological studies.

As shown in table 3 infectious virus was first detected in the spleen in small amounts on the third day p.i.

Later in infection kidney, liver, and lungs became infected. Immunoperoxidase and in situ hybridization studies confirmed these results. Furthermore, on the third day p.i. the bone marrow stained positive in both techniques.

\section{HIS Treatment}

The efficacy of HIS in modulating the lethal effects of RCMV infection was studied as described in Materials and methods.

The administration of a single dose of HIS at appropriate dilution, 1 day prior to challenge with $10^{5}$ PFU RCMV provided full protection to experimental animals (table 4).

Complete protection was afforded by the antiserum, when it was administered up to $24 \mathrm{~h}$ post-challenge, but this effect rapidly waned thereafter (day 2 or later).

Experiments using different infection doses $\left(10^{4}, 10^{5}\right.$, and $\left.10^{6}\right)$ gave similar resuits as shown in table 4.

Furthermore, when immunosuppression increased (6 Gy) no protective effect of HIS was observed even when HIS with a titre of 160 was used. 
Table 4. The effect of wariables in RCMV infection and treatment sclvedules on the survival of HAS treated rats. ${ }^{2}$.

\begin{tabular}{|c|c|c|c|c|c|c|c|}
\hline \multirow[t]{2}{*}{$\begin{array}{l}\text { Irradiation } \\
\text { (Gy) }\end{array}$} & \multirow[t]{2}{*}{$\begin{array}{l}\text { RCMV } \\
\left(\log _{10} \text { PFU) }\right.\end{array}$} & \multirow[t]{2}{*}{$\begin{array}{l}\text { Therapy } \\
\text { day }\end{array}$} & \multicolumn{5}{|c|}{$\begin{array}{l}\text { The number of survivors per group of rats } \\
\text { Neutralization titre of the His used }\end{array}$} \\
\hline & & & 5 & 10 & 20 & 40 & 80 \\
\hline 5 & 5 & -1 & 0 & 2 & 8 & 10 & 10 \\
\hline 5 & 5 & +1 & 0 & 0 & 1 & 8 & 10 \\
\hline 5 & 6 & -1 & 0 & 1 & 7 & 10 & 10 \\
\hline 5 & 4 & -1 & 0 & 2 & 7 & 10 & 10 \\
\hline
\end{tabular}

animals, which received total body irradiation and RCMV-infection, were treated with variable dilutions of HIS. Each group consisted of 10 rats.

The neutralization titre is expressed as the dilution of senm which contesponds with the ID $_{50 .}$ Undilutied serum provided an ID $_{50}$ of 160 .

Table 5. Effect of HIS administration on the presence of infectious virus in the infected rats ${ }^{\text {. }}$.

\begin{tabular}{|c|c|c|c|c|}
\hline \multirow[t]{2}{*}{ Therapy } & \multicolumn{4}{|c|}{ Virus titmes ${ }^{b}$} \\
\hline & Spleen & Kidney & Liver & Lungs \\
\hline Control serum & $5,6 \pm 1,3$ & $3.3 \pm 0,8$ & $5.3 \pm 1.4$ & $4.5 \pm 2,9$ \\
\hline HIS & $5.3 \pm 1,1$ & $2.9+0,6$ & neg," & neg." \\
\hline
\end{tabular}

aN rats were infected with $10^{3}$ PFU RCMV one day after $\mathrm{X}$-irradiation (5 Gy). Groups of 10 rats each were treated with $1 \mathrm{mil}$ HIS by i.v. route 1 day prior to infection or with megative control serum. Plaque assay was performed 7 days post-infection, mean \pm standard deviation.

b The virus titre in the organs is expressed as the log 10 PFU RCMV.

c meg. $<2.2 . P<0.01$.

As expected, in experimental animals receiving negative control serum, survival was low (1/10). Furthermore, rats receiving high dose TBI without treatnent (up to 7 Gy) never died. The lethal dose seemed to be 9 Gy.

In addition, in infected animals the effect of HIS therapy on the virus loads of several organs was studied. As shown in table 5, the number of infective virus particles in the spleen and kidneys was not influenced by HIS therapy, but in the liver and lungs a significant reduction in the number of infectious RCMV was noted $(P<0.01)$.

Finally, the effect of HIS treatment on organ pathology was examined. On macroscopic examination no symptoms of disease were noted in the HIS treated group. Histopathologic changes of lungs and liver were minimal and resembled those described by Bruning et al. (8) in the immunocompetent host. 


\section{Discussion}

Like human CMV, RCMV is poorly pathogenic in the immunocompetent host (6) but the virus maty cause severe disease under immunocompromised conditions. An inoculum of $10^{4}$ PJU or more of RCMV combined with severe immunosuppression ( 5 Gy TBI) resulted in symptomatic disease and a high mortality. Neither immunosuppression nor infection by itself caused disease or mortality. The incubation time varied between seven and fourteen days. Disease symptonatic correlated with the presence of infectious virus, viral antigens, and wiral DNA, which were found in high concentrations in spleen and liver, less in the lungs and bone marrow, even less in kidneys and eyes and sporadically in brain tissue.

Viral antigen detection by immunoperoxidase staining was slightly more sensitive than detection of viral DNA by in situ hybridization, but overall the results of these techniques correlated very wel.. Furthermore, the percentages of reactive cells using these techniques correlated well with those of the placue assays and dot blot hybridization.

Early occurrence of RCMV immunoreactive cells, predominantly macrophages, in the spleen was a constant finding in symptomatic infection, which parallels the situation in man where involvement of the spleen is a common finding in CMV infections (23). Also in mice splenic macrophages seem to play a role in the pathogenesis of lethal infection (17). In animals which died from infection, the spleens invariably showed extensive necrosis. Numerous monocytes and macrophages showed characteristic inclusions and frequently RCMV-specific immunoreactivity. Furthermore, a reduced volume of white pulp was observed, which is of interest in relation to the described immunosuppressive effect of CMV $(11,16,33)$.

In the kidneys RCMV-specific, immunoreactive mesangial cells could be detected in the glomeruli together with some proliferation of mesangium. The renal capsule contained many immunoreactive cells, which might account for relatively high virus yields in the plaque assay. In contrast, in the human kidney CMV localized predominantly in tubular epithelium and hardly ever in the glomerular cells (23). In immunocompromised patients a symptomatic CMV infection is frequently accompanied by hepatitis (29). The present findings in our model do closely resemble the pathological findings in HCMV hepatitis. Histologically, extensive liver damage was apparent with numerous inclusion bodies in hepatocytes, Kupfer cells, and bile duct epithelium and was accompanied by focall liver cell necrosis as described for HCMV hepatitis elsewhere $(31,32)$.

Pneumonitis is the leading cause of death in CMV-infected transplant patients (16). In some RCMV-infected rats numerous immunoreactive cells were found in the lungs, including alveolar macrophages and interstitial mononuclear cells, resembling the histopathology of HCMV-induced pneumonitis (16).

Athough in transplant patients CMV infection of the cerebrum is rare, in other immunosuppressed conditions, as in AIDS, cerebral involvement occurs frequently in the form of infection of glial cells and meurones (34). In this study infection of the brain was indeed detectable, albeit at a low level and without histological abnormallities. 
In this rat model, viral antigens were present in the retinal pigment layer. Most antigens occurred in blood-borne cells, a finding which supports the hypothesis of a haematogenous spread of infection in CMV retinitis.

In the bone marrow of RCMV-infected rats numerous cells displayed signs of CMV infection. This indicates a massive infection of the bone marrow, which may lead to immunosuppression as described in human and mouse studies $(1,22)$. The exact nature of infected cells still has to be investigated.

The applicability of this infection model for screening therapeutic strategies in CMV infection was evaluated using preventive antibody treatment. In man preventive administration of HIS in bone marrow transplant patients (21) and renal graft recipients (30) has a beneficial effect on morbidity and mortality. In the rat HIS administered prophylactically to animals receiving lethal challenges of virus plus X-irradiation can provide 100 per cent protection against RCMV infection. These results corroborate the findings in man,

Two possible mechanisms by which antibodies exert their protective effect are the neutrallization of free virus particles and the elimination of virus-infected cells by antibody-dependent cell-mediated cytotoxicity (ADCC). Results of our experiments suggest that the latter, i.e., the $A D C C$ plays a role in the protection against early RCMV infection.

First, antibodies administered 24 h p.i. still protect the host from acute RCMV infection, although at that time infectious virus particles cam be obtained neither from peritoneal washing fluid (5) nor from the blood serum (data not shown).

Second, a 100-fold increase of RCMV inoculum $\left(10^{4} \mathrm{PFU}\right.$ to $\left.10^{6} \mathrm{PFU}\right)$ does not require a higher neutralization titre of the HIS to protect against lethal infection (table 4) suggesting that the neutralization of free virus particles is not involved in our system.

Third, an increase of the irradiation dose ( 5 Gy to $6 \mathrm{~Gy}$ ) has a negative effect on the outcome of antibody treatment indicating that dose-related suppression of the cellular immune system influences the protective effect of antibodies.

These results corroborate the findings of Manischewitz et al. (18) and Quinnan et al. (25) indicating that $\mathrm{ADCC}$ plays a major role in the early phase (the first week) of acute $\mathrm{CMV}$ infection.

However the exact mechanism by which HIS prevents lethal infection in this model remains to be determined.

In HIS treated rats infection of the lungs and the liver was prevented (table 5). This is in contradiction to the finding in mice that in antibody-treated animals the virus load in the organs was the same as in non-treated animals $(26,27)$. At this moment we have no full explanation for the discrepancy in the virus content of the organs in these two animal species.

In conclusion, a model to study acute CMV infection in the immunocompromised host is described. It is characterized by high mortality and the full range of CMV-related lesions. The preference of the virus for different internal organs shows similarity with the situation in immunocompromised man. Furthermore, antibody treatment in the early stage of the infection was effective against mortality and viral spread to different organs.

Finally, this model provides the possibility to study the effect of chemotherapeutic and immunological intervention. 


\section{References}

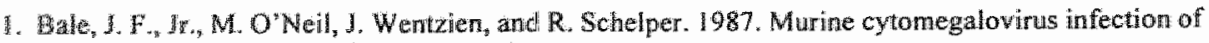
reaggregate cuturtur of fetal mouse brain. $J$ Neuropahol. Exp. Neurol. 46:72-83.

2. DA, F. I, B.P. Griffith; C. K. Fong, and G. D. Hsing 1983. Cytomegaloviral infections in the guinea pis: experimental models for human disease. Rev. Infect. Dis. 5:177-195.

3. Birnboim, H. C., and J. Doly. 1979. A rapid alkaline extraction procedure for screening recombinant plasmid DNA. Nuclerce. Acids. Res. 7:1513-1523.

4. Bruggeman, C. A, W. M. Debie, G. Grauls, G. Majoor, and C. P. van-Boven. 1983. Infection of laboratory wats with a new cytomegalo-like wirus. Arch. Virol. 76:189-199.

5. Bruggeman, C.A., G. Grauls, and C. P. A. van Boven. 1985. Susceptibility of peritoneal macrophages to rat cytomegalovirus infection. FEMS 27:263-266.

6. Bruggeman, C. A., H. Meijer, F. Bosman, and C. P. van-Boven. 1985. Biology of rat cytomegalovirus infection. Interviralogy 24:1-9.

7. Bruggeman, C. A., H. Meijer, P. H. J. Dormans, W. M. H. Debie, G. E. L. M. Grauls, and C. P. A. van Boven. 1982. Isolation of a cytomegalovirus-like agent from wild rats. Arch. Virol. 73:231-241.

8. Bruning, J. H. 1988. Cytomegalovirus infections in renal transplantation. Study in a rat model [Ph.D. Thesis], University of Limburg, Maastricht.

9. Bruning, J. H., C. A. Bruggeman, C. P. van-Boven, and P. J. wan-Breda-Vriesman. 1986. Passive transfer of cytomegalovirus by cardiac and renal organ transplants in a rat model. Transplantarion. 41:695-698.

10. Bruning, ل.H., W.H. Debie, P. H. Dormaris, H. Meijer, and C. A. Bruggeman, 1987. The development and characterization of monoclonal antibodies against rat cytomegalovirus induced antigens. Arch. Virol 94:55-70.

11. Buckley, P. J., S. A. Dickson, and W. S. Walker. 1985. Human splenic sinusoidal lining cells express antigens associated with monocytes, macrophages, endothelial cells, and T lymphocytes. $J$. Immunol. $134: 2310-2315$.

12. Gehan, E. 1956. Generalized Wilcoxon test for comparing arbitrarily single sensored samples. Biometrica 52:203-224.

13. Gobel, U., R. Maas, and A. Clad. 1987. Quantitative electroelution of oligonucleotides and large DNA fragments from gels and purification by electrodialysis. J. Biochem. Biophys. Merhods. 1.4:245-260.

14. Gross, A. J, and V. A. Clarck. 1975. Survival distributions: reliability applications in the biomedical sciences. John Wiley and Sons, Inc, New York.pp.

15. Hendrix, M. O., P. H. Dormans, P. Kitslaar, F. Bosman, and C. A. Bruggeman. 1989. The presence of cytomegalowirus nucleic acids in arterial walls of atherosclerotic and nonatherosclerotic patients. Am. J. Pathol 134:1151-1157.

16. Ho, M. 1991. Cyiomegalovirus. Biology and Infection. Plenum Medical Book Company, New York. $440 \mathrm{pp}$.

17. Katzenstein, D. A., G.S. Yu, and M. C. Jordan. 1983. Lethat infection with murine cytomegalovirus after early viral replication in the spleen. J. Infect. Dis. 148:406-411.

18. Manischewitz, J. $E_{n y}$ and G. V.J. Quirnan. 1980. Antivirus antibody-dependent cell-mediated cytotoxicity during murine cytomegalovirus infection. Infect. Immunity: 29:1050-1054.

19. Meijer, H., P. H. Dormans, J. L. Geelen, and C. P. van-Boven. 1984. Rat cytomegahovirus: studies on the viral genome and the proteins of virions and nucleocapsids. J. Gen. Virol. 65 (Pt 4):681-695.

20. Meijer, H., J.C. Dreesen, and C. P. Van-Boven. 1986. Molecular cloning and restriction endonuclease mapping of the rat cytomegalovirus genome. J. Gem. Virol. $67(\mathrm{Pt} 7): 1327-1342$. 
21. Meyers, J. D., J. Leszczynski, J. A. Zaia, N. Floumoy, B. Newton, D. R. Snydman, G. G. Wright, M. J. Levin, and E. D. Thomas 1983. Prewention of cytomegalovirus infection by cytonegalovirus immune globulin after marrow transplantation. An. Intern Med, 98:442-446.

22. Mutter, W. M. J. Reddehase, F. W. Busch, H. J. Buhring, and U. H. Koszinowski. 1988, Failure in generating hemopoletic stem cells is the primary cause of death from cytomegalovirus disease in the immunocompromised host. J. Exp. Med. 167:1645-1658.

23. Plotkin, S. A., S. Michelson, J. S. Pagano, and F. Rapp. 1984. CMV: pathogenesis and prevention of cytomegalovirus infection.

24. Plummer, G., and M. Benyesh-Melnick. 1964. A plaque reduction neutralization test for buman cytomegalovirus. Proc. Soc. Exp. Biol. Med. 117:145-150.

25. Quinnan, G. V., and J. E. Manischewitz, 1979. The role of natural killer cells and antibodydependent cell-mediated cytotoxicity during murine cytomegalovirus infection. \&. Exp. Med. 150:1549-1554.

26. Rubin, R. H., E. J. Wilson, L. V. Barrett, and.D. N. Medearis. 1986. The protective effects of hyperimmune anti-murine cytomegalovirus antiserum against lethal wiral challenge: the case for passive-active immunization. Clin. Immunol. Immunopathol 39:151-158.

27. Shanley, J. D., M. C. Jordan, and J. G. Stevens. 1981. Modification by adoptive immumity of murine cytomegalovirus infection. J. Inf. Dis. 143:231-237.

28. Smith, L. J., R. C. Braylan, J. E. Nutkis, K. B. Edmundson, J. R. Downing, and E. K. Wakeland. 1987. Extraction of cellular DNA from human cells and tissues fixed in ethanol. Anal. Biochem. $160: 135-138$.

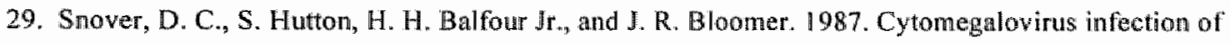
the liver in transplant recipients. J. Clin. Gastrocnterol 9:659-665.

30. Snydman, D. R., B. G. Werner, B. Heinze-Lacey, V. P. Berardi, N. L. Tilney, R. L. K. itkman, E. L. Malford, S. 1. Cho, H. L. Bush Jr, A. S. Levey, T. B. Strom, C. B. Carpenter, R. H. Levey, W. E. Harmon, C. E. Zimmerman, M. E. Shapiro, T. Steimman, F. LoGerfo, B. Idelson, G. P. J. Schröter, M. J. Levin, J. Mclver, J. Leszczynski, and G. F. Grady. 1987. Use of cytomegalovirus immure globulin to prevent cytomegalovirus disease in renal-transplant recipients. $N$. Engl. J. Med. 317:1049. 1054 .

31. Ten-Nape1, H. H., H. J. Houthoff, and T. H. The. 1984. Cytomegalovirus hepatitis in normal and immune compromised hosts. Liver. 4:184-194.

32. Vanstapel, M. J., and V. J. Desmet. 1983. Cytomegalovirus hepatitis: a histological and immunohistochemical study. Appl. Pathol. $1 \$ 41-49$.

33. Whyte, P. F., R. Subramaniam, and J. B. Hudson. 1987. Characterization of a murine cytomegalovirus-induced immunosuppressive tactor. Arch. Virol 96:169-183.

34. Willey, C. A., and J. A. Nelson. 1988. Role of thuman immunodeficiency virus and cytomegalovilus in AIDS encephalitis. Am. J. Pahol $133 ; 73-81$. 


\section{3}

\section{Comparative activity of (S)-1-(3-hydroxy-2-phosphonyl- methoxypropyl)cytosine and 9-(1,3-dihydroxy-2-pro- poxymethyl)guanine against rat cytomegalovirus infection in vitro and in vivo}

\section{Summary}

Two antiviral compounds, (S)-1-(3-hydroxy-2-phosphonylmethoxypropyl)cytosine (HPMPC) and 9-(1,3-dihydroxy-2-propoxymethyl)guanine (DHPG), were evaluated for their inhibitory effects on human cytomegallovirus (HCMV) replication in humam embryonal fibroblasts on rat cytomegalovirus (RCMV) replication in rat embryonal fibroblasts. The concentrations of HPMPC or DHPG required to inhibit HCMV plaque formation by $50 \%$ were 0.1 and $0.6 \mu \mathrm{g} / \mathrm{m}$, respectively. For RCMV, these values were 1.1 and $25 \mu \mathrm{g} / \mathrm{ml}$, respectively. For HCMV, the selectivity indices of HPMPC and DHPG, as determined by the ratio of the $50 \%$ inhibitory concentration for cell growth to the $50 \%$ inhibitory concentration for virus plaque formation, were 1,250 and 140, and for RCMV, they were 500 and 76 , respectively. HPMPC was far more active than DHPG against RCMV infection in vivo, as measured by mortality, histopathological changes, and virus titres in organs of immunocompromised RCMV-infected rats. The minimal effective dosage required to prevent mortality from RCMV infection was a single dose of HPMPC at $2 \mathrm{mg} / \mathrm{kg}$ of body weight compared with DHPG therapy twice daily at $20 \mathrm{mg} / \mathrm{kg} /$ day for 5 days. Furthermore, HPMPC was more effective than DHPG in reducing virus titres in internal organs $(P<0.01)$ and in RCMV-induced histopathologic lesions.

In contrast to DHPG, which did not show activity when administered 1 day before infection, HPMPC was effective even when administered 7 days before RCMV infection. 


\section{Introduction}

Human cytomegalovirus (HCMV) has been recognized as one of the most important pathogens in immunocompromised hosts $(10,13)$, including patients with AIDS and recipients of bone marrow transplants, in whom $\mathrm{HCMV}$ is the most frequent cause of death $(10,17)$. Few nucleoside analogs have been reported to be effective against HCMV in vitro, and most of these have relatively low selectivity indices (18). Only two drugs, 9-(1,3-dihydroxy-2-propoxymethyl)guanine (DHPG; ganciclovir) and phosphonoformic acid (PFA), have been shown to be therapeutically effective against HCMV disease (15). However, the clinical use of these agents is limited by severe adverse reactions (5). Therefore, the search for more-potent and less-toxic antiviral drugs for chemotherapy in HCMV infections has to be continued. Recently, new class of acyclic nucleoside phosphonate analogs has been described $(6,7$, 20). Of these compounds, (S)-1-(3-hydroxy-2-phosphonylmethoxypropyl)cytosine (HPMPC) seems to be the most potent and most selective inhibitor of CMV replication in vitro (18). In the present study, we compared the inhibitory effect of HPMPC on rat CMV (RCMV) and HCMV replication in cultured cells with that of DHPG. Furthermore, we compared the efficacy of HPMPC with that of DHPG in a rat model (19) for CMV infection in the immunocompromised host and inwestigated the efficacy of prophylactic treatment with HPMPC on a lethal CMV infection in rats.

\section{Materials and methods}

\section{Viruses}

For in vitro tests with HCMV, the AD169 strain (ATCC VR 807) was used. RCMV, isolated by Bruggeman et al. from wild rats (3) and characterized by Meijer et al. (14), was used for studies with the rat model. For in vitro studies, we used RCMV and HCMV obtained from cell culture supernatant (2). For in vivo studies, RCMV was obtained from suspensions of salivary gland tissue of rats after several in vivo passages (2).

\section{Antiviral agents}

DHPG was obtained from Syntex Inc., Palo Alto, Calif, and HPMPC was synthesized by I. Rosenberg and A. Holy (Czechoslovak Academy of Sciences, Prague, Czechoslovakia) (11).

\section{Virus plaque assays and virus plaque inhibition assays}

Rat embryonal fibroblasts (REF) were obtained as described before (19). REF and human lung embryonal fibroblasts (HEF) (Flow 2002, Amstelstad, Zwanenburg, The Netherlands) were grown in Eagle's minimal essential medium supplemented with $10 \%$ inactivated 
new-born calf serum (NCS; Westburg), $2 \mathrm{mM} \mathrm{L}$-glutamine, and $24 \mathrm{mM}$ sodium bicarbonate (growth medium) in 24-well culture plates (Greiner, Alphen aan de Rijn, The Netherlands). For plaque assays with organ tissues, $10 \%$ homogenates (wt/vol.) were prepared in basal medium Eagle (BME) supplemented with $2 \% \mathrm{NCS}, 2 \mathrm{mM} \mathrm{L}$-glutamine and $24 \mathrm{mM}$ sodium bicarbonate, and after centrifugation, triplicate samples of the supernatant and serial 10-fold dilutions in BME with $2 \% \mathrm{NCS}$ were incubated for $\mathrm{I}$ h at $37^{\circ} \mathrm{C}$ on a $90 \%$ confluent monolayer of REF. Then the supernatants were removed and replaced by BME with $2 \%$ NCS with agar overlay. After an incubation period of 7 days, the number of plaques was monitored microscopically following formaldehyde fixation and staining with methylene blue.

For plaque inhibition assays, $90 \%$ confluent REF and HEF monolayers were infected with about 150 plaque-forming units (PFU) of RCMV or HCMV per well, respectively. The viruses were diluted in $\mathrm{BME}$ with $2 \% \mathrm{NCS}$ and supplements. After $1 \mathrm{~h}$ of incubation at $37^{\circ} \mathrm{C}, \mathrm{BME}$ was removed and replaced by medium containing concentrations ranging from 200 to 0.01 $\mu \mathrm{g} / \mathrm{ml}$ of the antiviral compound per $\mathrm{ml}$ in BME with supplements with and without agarose overlay in triplicate. After 7 and 10 days of incubation for RCMV and HCMV, respectively, the number of plaques was monitored as described above. The effective concentration of the compound is expressed as the concentration required to inhibit plaque formation by $50 \%$ $\left(\mathrm{EC}_{50}\right)$. The $\mathrm{EC}_{50}$ was estimated from the number of plaques on semi-logarithmic graphs as a function of the concentration of the antiviral compounds. In time-of-addition experiments, antiviral agents were added to HEF and REF at different days before and after infection $(-7$, $-5,-3,-1,0,+1,+3,+5$, and +7 days) and incubated for $24 \mathrm{~h}$ at $37^{\circ} \mathrm{C}$. Thereafter, the supernatant containing the antiviral drugs was removed and replaced by fresh BME with $2 \%$ NCS. The cell cultures were inoculated as described above, and the plaques were counted at 7 days post. infection (p.i.).

\section{Growth inhibition assay}

The inhibitory effects of DHPG and HPMPC on HEF and REF growth were determined by seeding $3 \times 10^{3}$ cells per well in 96-well microtiter plates (Greiner) in growth medium. After $24 \mathrm{~h}$, the medium was removed and replaced by growth medium containing various concentrations of the test compound allowing maximal replication. After three days of incubation at $37^{\circ} \mathrm{C}$, the cell number was determined with a coulter counter. The inhibitory concentration of the compound is expressed as the $\mathrm{IC}_{50}$, or concentration required to reduce cell growth by $50 \%$. The selectivity index corresponds to the ratio of $\mathrm{IC}_{50}$ for cell growth to the $\mathrm{EC}_{50}$ for RCMV replication.

\section{Animal inoculation and treatment}

Specific-pathogen-free 8-week-old male Brown Norway rats (140 to $180 \mathrm{~g}$ ) received total body irradiation (TBI) of 5 Gray (Gy) and were inoculated intraperitoneally with $1 \mathrm{ml}$ of $10^{5}$ PFU of RCMV as described before (19). DHPG and HPMPC were administered intraperitoneally at different times before and after virus inoculation as described below. The injected 
dose was adjusted to the actual body weight. Sham-treated animals were injected intraperitoneally with sterile phosphate-buffered saline. Uninfected negative controls received the same dilution of RCMV-negative salivary gland suspension and 5 Gy of TBI. Groups receiving virus or irradiation only were also included in the study.

\section{Survival scores and specimen collection}

Rats were examined daily and survival was recorded. The in vivo activity of the drug is expressed as the minimal effective dose, or the daily dose at which at least $50 \%$ of the animals survived the lethal infection $\left(\mathrm{ED}_{50}\right)$.

To study the effect of treatment on virus titres in organs, DHPG- or HPMPC-treated rats and untreated rats, were sacrificed 7 days p.i. Virus titres in organs were measured as described earlier (19). In short, spleen, liver, lungs, kidneys, and salivary glands were removed aseptically, homogenized in a tissue grinder, and suspended in BME with $2 \% \mathrm{NCS}$, and plaque assays were performed.

For histopathological examination, organs were fixed in paraformaldehyde-lysine-periodate, embedded in paraffin, and processed as described before (19).

For detecting RCMV antigen, monoclonal antibodies directed against a $29 \mathrm{kDa}$ polypeptide of RCMV and against 41-, 46-, and $91 \mathrm{kDa}$ polypeptides were used (4). Specificity was analyzed as described previously (19).

\section{Statistical analysis}

For statistics on the in vitro results, the Mann-Whitney test and Fisher's exact test were applied. For comparison of survival curves, the generalized Wilcoxon test by Gehan was used (8). $P$-values of $<0.05$ were considered statistically significant.

\section{RESULTS}

\section{Inhibition of virus plaque formation and cytotoxicity in vitro}

Dose-response curves for the antiviral activity and cytotoxicity of HPMPC and DHPG are presented in figure 1. HPMPC inhibited HCMV plaque formation at an $\mathrm{EC}_{50}$ of $0.10(0.07$ to $0.16) \mu \mathrm{g} / \mathrm{ml}$ and RCMV plaque formation at an $\mathrm{EC}_{50}$ of $0.6(0.4$ to 0.9$) \mu \mathrm{g} / \mathrm{ml}$. The EC 50 of DHPG was $1.1(0.6$ to 1.8$) \mu \mathrm{g} / \mathrm{ml}$ for HCMV and $25(14$ to 40$) \mu \mathrm{g} / \mathrm{ml}$ for RCMV. The IC $\mathrm{C}_{50 \mathrm{~s}}$ of DHPG and HPMPC in uninfected HEF were $150(100$ to 220$)$ and $125(80$ to 185$) \mu \mathrm{g} / \mathrm{ml}$, respectively, whereas the corresponding values in REF were $1,900(1,260$ to 2,800) and 300 (230 to 390$) \mu \mathrm{g} / \mathrm{ml}$, respectively (figure 1). The selectivity indices (ratio of $/ \mathrm{C}_{50}$ to $\mathrm{EC}_{50}$ for CMV plaque formation) of DHPG for HCMV and RCMV were 140 and 76 , respectively. The selectivity indices of HPMPC for HCMV and RCMV were 1,250 and 500, respectively. In 


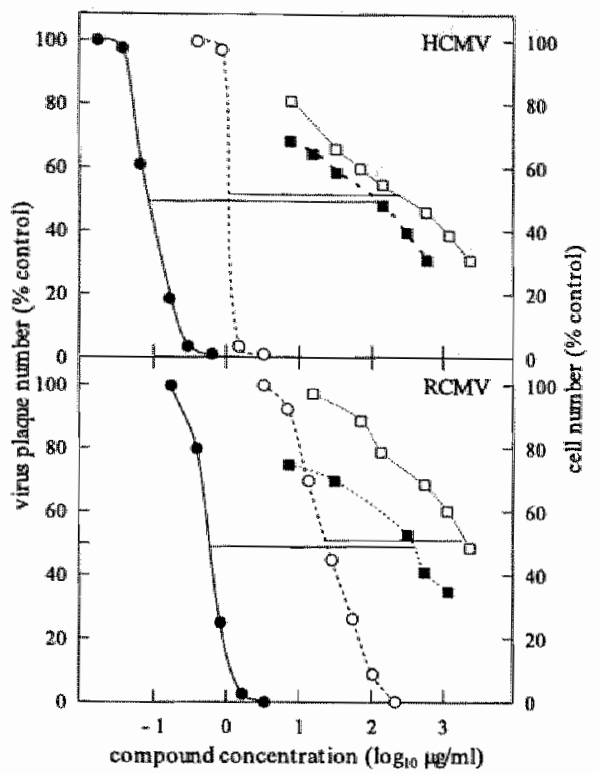

Figure 1. Dose-response curves for antiviral activity of DHPG and HPMPC in vitro. Virus plaque inhibition by HPMPC (๑) and DHPG (O) and cytotoxicity of HPMPC (a) and DHPG (D) are shown. Points represent the mean values of two separate experiments performed in triplicate. Standard deviation is $x \times 1.5$.

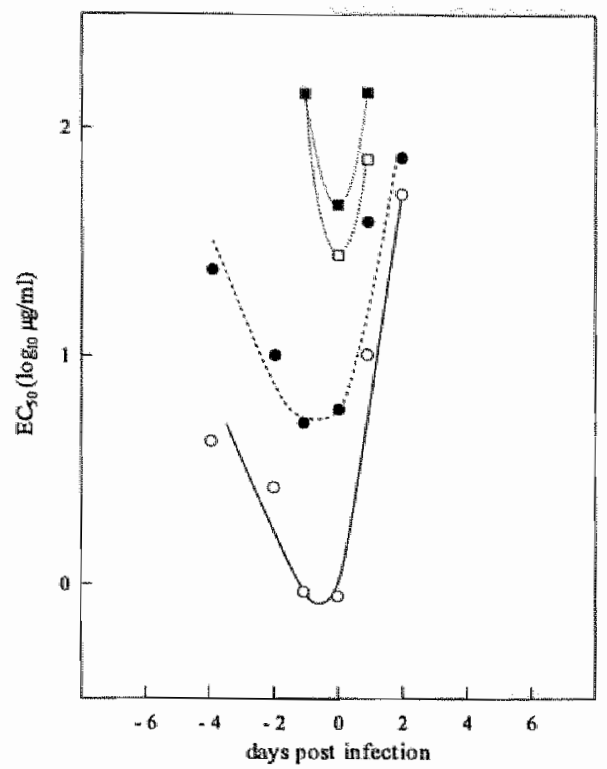

Figure 2. Time-of-addition curves for antivinal activity in vitro $\left(\mathrm{EC}_{50}\right)$. Symbols: $\mathrm{O}_{3} \mathrm{EC}_{50}$ of HPMPC for" HCMV; - ECso of HPMPC for RCMV; $\square$, ECso of DHPG for HCMV; 2, EC 50 of DHPG for RCMV.

HEF, HPMPC has a ninefold-higher selectivity than DHPG, whereas in REF, the selectivity index of HPMPC is seven times higher than that of DHPG.

\section{Time of addition experiments}

When drugs were added at $6 \mathrm{~h}$ p.i. and remowed $24 \mathrm{~h}$ later, the $\mathrm{EC}_{50 \mathrm{~S}}$ of HPMPC and DHPG in HCMV-infected HEF cells were 0.8 and 35 , respectively (figure 2). However, when drugs were added 1 day p.i. and removed $24 \mathrm{~h}$ later, the ECs0s of HPMPC and DHPG increased significantly to 12 and $200 \mu \mathrm{g} / \mathrm{ml}$, respectively. When HPMPC was added $48 \mathrm{~h}$ p.i. and removed $24 \mathrm{~h}$ later, it was less inhibitory to HCMV plaque formation $(70 \mu \mathrm{g} / \mathrm{ml})$, and when treatment was delayed until 3 days p.i. or later, no differences between treated and untreated cells were recorded $\left(\mathrm{EC}_{50} 100 \mu \mathrm{g} / \mathrm{ml}\right)$.

Even when administered 4 days before infection and removed $24 \mathrm{~h}$ later, HPMPC inhibited HCMV replication (figure 2). In contrast, DHPG at $100 \mu \mathrm{g} / \mathrm{ml}$ added 1 day before infection did not affect HCMV replication. For RCMV infection, the $\mathrm{EC}_{50}$ of HPMPC were 10 times 
Trable 1. Effects of different treatment schedules on survival of $R C M V$-infected immunocompromised rats ${ }^{\mathrm{z}}$.

\begin{tabular}{ll}
\hline $\begin{array}{l}\text { Treatinient schedule } \\
\text { (day[s] of treatinient) }\end{array}$ & $\begin{array}{l}\text { No. of survivors/ } \\
\text { total no. of rats }\end{array}$ \\
\hline DHPG 20 mg/kg/day & \\
$0-7$ & $10 / 10$ \\
$0-5$ & $10 / 10$ \\
$0-3$ & $1 / 10$ \\
$0^{c}$ & $0 / 5$ \\
HPMPC 20 mg/kg & \\
$0-5$ & \\
$0-3$ & $5 / 5$ \\
$0^{\mathrm{d}}$ & $10 / 10$ \\
\hline
\end{tabular}

"All experiments were performed with groups of 5 rats each. Important data were run in duplicate experiments.

"DHPG was administered intraperitoneally twice daily, and HPMPC was administered once dailly.

One dose of DHPG (100 $\mathrm{mg} / \mathrm{kg})$.

"One dose of HPMPC (20 mg/kg) at $6 \mathrm{~h} \mathrm{p.i.}$

higher than those for HCMV, but otherwise, the kinetics were similar (figure 2). DHPG had almost no effect on HCMV or RCMV infection if added for a short time ( $24 \mathrm{~h})$.

\section{The effect of treatment on survival in RCMV-infected rats}

As outlined in table 1, DHPG therapy started $6 \mathrm{~h}$ p.i. and continued for 5 days with a dose interval of $12 \mathrm{~h}$ prevented mortality from RCMV infection in irradiated rats, but DHPG treatment for 3 days was not effective. In contrast, HPMPC administered for 3 days or as a single dose prevented death from RCMV infection.

The $\mathrm{ED}_{50 \mathrm{~s}}$ were determined with these treatment schedules (table 2). The ED 50 for DHPG (twice daily for 5 days) was $20 \mathrm{mg} / \mathrm{kg} /$ day. The ED so $_{0}$ for HPMPC (administered in a single dose at $6 \mathrm{~h} \mathrm{p.i.)} \mathrm{was} 2 \mathrm{mg} / \mathrm{kg}$.

In the control groups, rats which had received either TBI or RCMV only survived, as did the rats which had received CMV-negative salivary gland homogenate. Untreated irradiated RCMV-infected animals did not survive infection.

\section{Time response relation between treatment and survival}

A single dose of HPMPC ( $20 \mathrm{mg} / \mathrm{kg})$ was effective if given on day 0,1 or 2 p.i. but not on day 3,5 , or 7 p.i. (table 2). DHPG was not effective if given as a single dose ( 6 h p.i.). DHPG treatment was effective only if treatment was started $6 \mathrm{~h}$ p.i. and doses were given twice daily 
Table 2. Survival from RCMV infection ${ }^{\text {a }}$ after antiviral treatnent with different treatment schedules and dosage regimes.

\begin{tabular}{llll}
\hline $\begin{array}{l}\text { Antiviral } \\
\text { agent }^{\mathrm{b}}\end{array}$ & $\begin{array}{l}\text { Dosage } \\
\text { (mg/kg/day) }\end{array}$ & $\begin{array}{l}\text { Schedule } \\
\text { (day) }\end{array}$ & $\begin{array}{l}\text { No. of survivors } \\
\text { total no. of rats }\end{array}$ \\
\hline PBS & 0 & 0 to & $0 / 20$ \\
DHPG & 5 & 0 to 5 & $0 / 10$ \\
& 10 & 0 to 5 & $0 / 10$ \\
& 20 & 0 to 5 & $15 / 20^{\mathrm{d}}$ \\
& 40 & 0 to 5 & $9 / 10^{\mathrm{d}}$ \\
& 40 & 2 to 7 & $0 / 10$ \\
& 40 & 5 to 11 & $0 / 5$ \\
& 40 & 0 & $0 / 5$ \\
HPMPC & 100 & 1 & $0 / 5$ \\
& 0.5 & 0 & $0 / 10$ \\
& 1 & 0 & $3 / 10$ \\
& 2 & 0 & $10 / 10^{\mathrm{d}}$ \\
& 5 & 0 & $10 / 10^{\mathrm{di}}$ \\
& 10 & 0 & $10 / 10^{\mathrm{d}}$ \\
& 10 & 1 & $10 / 10^{\mathrm{d}}$ \\
& 10 & 2 & $8 / 10^{\mathrm{d}}$ \\
& 10 & 3 & $0 / 10$ \\
& 10 & 6 & $0 / 5$ \\
& 10 & -7 & $10 / 10^{\mathrm{d}}$ \\
& 5 & -7 & $6 / 10$ \\
2 & -7 & $0 / 10$ \\
& 1 & -7 & $0 / 5$ \\
\hline
\end{tabular}

a To establish lethal RCMV infection rats received 5 Gy of TBI and $10^{5} \mathrm{PFU}$ of RCMV. Experiments were carried out with groups of five rats each, and cumulative data of separate experiments are presented.

${ }^{b}$ Treatment, started at day 0 , wass administered from $6 \mathrm{~h}$ post infection.

c Survival was measured 21 days post infection.

d $P<0.05$, as calculated with the gemeralized Wilcoxon test by Gehan (8).

PBS, phosphate-buffered saline.

for 5 days. Neither HPMPC nor DHPG was effective if therapy started at 3 days (or later) after infection.

The effect of preventive treatment with HPMPC or DHPG on survival was determined by giving a single dose $(10 \mathrm{mg} / \mathrm{kg})$ of HPMPC on day $-7,-5,-3$ or -1 before TBI and RCMV inoculation. All HPMPC-treated rats survived. In contrast, all rats which received one dose $(100 \mathrm{mg} / \mathrm{kg})$ of DHPG $12 \mathrm{~h}$ before virus inoculation and all untreated rats died from RCMV infection $(P<0.01)$ and had high virus titres in internal organs (data not shown). 
Table 3. Effect of HPMPC and DHPO treatment on organ vins titres in RCMV-infected irradiated rats.

\begin{tabular}{lllll}
\hline & \multicolumn{4}{c}{ Virus titre logio PFU/g tissue (mean \pm standard deviation) } \\
\cline { 2 - 5 } Treatment & Saliwary gland & Spleen & Liver & Lungs \\
\hline DHPG, 20 mg/kg & $1.89 \pm 0.22^{\mathrm{d}}$ & $3.99 \pm 1.54^{\mathrm{d}}$ & $2.94 \pm 1.21^{\mathrm{d}}$ & $2.87 \pm 11.84^{\mathrm{d}}$ \\
HPMPC $^{\mathrm{b}}$ & & & & \\
$5 \mathrm{mg} / \mathrm{kg}$ & $2.27 \pm 0.62^{\mathrm{d}}$ & $3.05 \pm 1.26^{\mathrm{d}}$ & $1.79 \pm 0.54^{\mathrm{d}}$ & $2.96 \pm 0.96^{\mathrm{d}}$ \\
$20 \mathrm{mg} / \mathrm{kg}$ & $<1.39^{\mathrm{f}}$ & $<1.39^{\mathrm{f}}$ & $<1.39^{\mathrm{f}}$ & $<1.39^{\mathrm{f}}$ \\
untreated & $3.51 \pm 0.27$ & $6.17 \pm 0.52$ & $5.49 \pm 0.26$ & $5.12 \pm 0.30$ \\
\hline
\end{tabular}

${ }^{a}$ Groups of 5 rats each received 5 Gy TBI and $10^{5}$ PFU RCMV.

${ }^{b}$ Detection limit was 1.39 .

${ }^{\mathrm{c}}$ Treatment was started at $6 \mathrm{~h}$ post infection and continued twice daily for 5 days.

d $p<0.05$.

Administered as a single dose 6 th post infection.

$p<0.01$.

A dose-response relationship was established with RCMV-infected rats which received a single HPMPC dose (different dosages) at 7 days before virus inoculation. The $\mathrm{ED}_{50}$ for HPMPC under these conditions was $10 \mathrm{mg} / \mathrm{kg}$ (table 2).

\section{Effect of treatment on virus titres in organs}

Table 3 shows the effects of these treatment regimens on the virus titres in several organs at 7 days p.i. In the DHPG ( $20 \mathrm{mg} / \mathrm{kg} /$ day for 5 days) treatment group, virus titres in spleen, liver, and lungs were reduced by $3 \log 10$ values compared with titres in untreated controls $(P<0.01)$. However, DHPG at $10 \mathrm{mg} / \mathrm{kg} /$ day for 5 days did not markedly reduce virus titres (data not shown). In contrast, a single dose of $\mathrm{HPMPC}$ at $5 \mathrm{mg} / \mathrm{kg}$ caused a significant reduction in virus titres in liver and lung compared with those in untreated controls $(P<0.05)$; furthermore, a single dose of HPMPC at $20 \mathrm{mg} / \mathrm{kg}$ reduced virus titres in all organs to below detection level $(P<0.01)$. A single dose of HPMPC at $\mathbb{m g} / \mathrm{kg}$ did not affect virus titres in internal organs (data not shown).

\section{The effect of treatment on RCMV-induced histopathological changes}

Histopathological abnormalities in untreated lethally RCMV-infected rats have been described previously (19). In short, massive infection of the spleen is accompanied by an almost complete disappearance of the periarteriolar lymphocyte sheaths and massive congestion with RCMV-containing macrophages. The liver parenchyma shows patchy necroses, many mononuclear cells $\mathrm{s}_{\mathrm{w}}$ and numerous virus-infected hepatocytes with characteristic inclusion bodies. In the lungs, the interstitium shows congestion, with haemorrhages and infiltrating macrophages. Bone marrow smears show intensely immunoreactive mononuclear cells, whereas the kidneys show only discrete abnormalities (19). 
In the liver of the DHPG-treated group (20 mg/kg/day for 5 days), parenchynal necrosis was almost absent, although mononuclear cells scattered throughout the parenchyma and relatively few RCMV-containing hepatocytes showed nuclear inclusions. In the spleen, periarteriolar lymphocyte sheaths remained at almost normal size, but congestion of sinuses with macrophages was noted. In the lungs, haemorrhages were prevented, but RCMV-containing macrophages persisted and in bone marrow, few immunoreactive mononuclear cells persisted. No virus-associated or drug-associated pathological changes could be detected in any of the internal organs of the RCMV-infected rats treated with HPMPC at $20 \mathrm{mg} / \mathrm{kg}$ at $6 \mathrm{~h}$ p.i. In hematoxylin-and-eosin-stained sections, organs showed no histopathological changes which indicated hepatotoxicity, nephrotoxicity, or bone marrow toxicity at this dosage regimen.

\section{Discussion}

HPMPC is a very potent and selective inhibitor for ICMV in vitro (18). The compound inhibits the replication of HCMV in HEF at a 10 -fold-lower concentration than DHPG does. Our in vitro studies confirm that HPMPC is a potent and selective inhibitor of HCMV in HEF and indicate that the drug is also effective against RCMV in REF (figure 1). Compared with DIPG, HPMPC is nine- and sevenfold more selective against HCMV and RCMV, respectively. Snoeck et al. (18) also reponted that HPMPC added immediately p.i. for $24 \mathrm{~h}$ is very effective against $C M V$ infection in vitro. We confirmed that in contrast to DHPG, HPMPC is active against HCMV, following a short $(24 \mathrm{~h})$ incubation. In time-of-addition experiments, we found that HPMPC was effective in vitro if added early (within $24 \mathrm{~h}$ ) after virus infection. Also, HPMPC was effective against HCMV and RCMV when cell monolayers were exposed to the drug for $24 \mathrm{~h}$ as early as 4 days prior to infection. Under similar conditions, DHPG was not effective against CMV infection. Thus, the in vitro data suggest that HPMPC has three advantages over DHPG: a higher selectivity index, effectiveness after a short incubation, and prolonged duration of activity after removal from cell culture medium.

MPMPC was also more potent than DHPG in the treatment of RCMV infection in vivo. Thus, the total amount of drug required to protect rats agains RCMV infection was 50 times less for HPMPC than for DHPG. These studies also found evidence of a prolonged residual effect in that rats given one dose of HPMPC 7 days before RCMV infection $(10 \mathrm{mg} / \mathrm{kg})$ or at $6 \mathrm{~h}$ after infection ( $2 \mathrm{mg} / \mathrm{kg}$ ) were completely protected against the lethal outcome of disease. It has been reported that HPMPC and its active metabolites have a relatively long intracelular half-life (24 to $48 \mathrm{~h}$ ) (9). This long half-life also may occur in vivo and account for the prolonged prophylactic and therapeutic responses noted after a single dose of the compound. Treatment with a single dose of HPMPC at $5 \mathrm{mg} / \mathrm{kg}$ at $6 \mathrm{~h} \mathrm{p}$.i. led to a substantial reduction in virus titre comparable to the virus titre reduction achieved with DHPG at $20 \mathrm{mg} / \mathrm{kg} /$ day for 5 days. Moreover, one dose of HPMPC (20 mg/kg) at $6 \mathrm{~h}$ p.i. completely inhibited RCMV replication in the internal organs. These findings are in contrast to the findings of Li et al. (12), who reported that virus titres in organs of guinea pigs infected with guinea pig CMV were not influenced by HPMPC treatment at $2.5 \mathrm{mg} / \mathrm{kg} / \mathrm{day}$ for 5 days. In guinea pigs treated 


\section{Chapter 3}

with HPMPC at 5 or $10 \mathrm{mg} / \mathrm{kg} /$ day for 5 days, Li et al. (12) observed death and histopathological changes in kidneys and bone marrow due to toxicity of the compound. However, in rats receiving HPMPC at $20 \mathrm{mg} / \mathrm{kg} / \mathrm{day}$ for 5 days, no deaths were noted, nor were there any toxic histopathological changes. Moreover, toxicity studies in mice revealed that the toxic dose for HPMPC for mice is well above $200 \mathrm{mg} / \mathrm{kg} /$ day (1). Also, Neyts (16) noted that even if HPMPC is administered at $400 \mathrm{mg} / \mathrm{kg} / \mathrm{day}$ for 5 days, it is not toxic to mice but instead completely protects the mice against a lethal intracerebral herpes simplex infection.

In summary, the present study has demonstrated that HPMPC is a selective and potent inthibitor of HCMV and RCMV replication in vitro. The compound is also active against RCMV infection in immunocompromised (irradiated) rats at doses that are non-toxic to these animals. The compound effectively reduces virus titres in internal organs and prevents RCMV-induced pathological changes. Furthermore, HPMPC is active prophylactically if given as a single dose 7 days before infection. HPMPC in the treatment of CMV infection in the immunocompromised host warrants further evaluation.

\section{References}

1. Bronson, J. J., I. Ghazzouli, M. J. Hitchcock, R. R. Webb 2d., and J. C. Martin. 1989. Synthesis and antiviral activity of the nucleotide analogue (S)-1-[3-hydroxy-2-(phosphony/methoxy)propyl]cytosine. I. Med. Chem. 32:1457-1.463.

2. Bruggeman, C. A., H. Meijer, F. Bosman, and C. P. van-Boven. 1985. Biology of rat cytomegalovirus infection. Intervirology: 24:1-9.

3. Bruggeman, C. A., H. Meijer, P. H. J. Dormans, W. M. H. Debie, G. E. L. M. Grauls, and C. P. A. van Bowen. 1982. Isolation of a cytomegalovirus-like agent from wild rats. Arch. Virol. 73:231-24】.

4. Bruning, J. H., W. H. Debie, P. H. Dormans, H. Meijer, and C. A. Bruggeman. 1987. The development and characterization of monoclonal antibodies against rat cytomegalovirus induced antigens. Arch. Virol. 94:55-70.

5. Collaborative DHPG Treatment Study Group. 1986. Treatment of serious cytomegalovirus infections with 9-(1.3-dihydroxy-2-propoxymethyl)guanine in patients with AIDS and other immunodeficiencies. N. Eingl. J. Med. 314:801-805.

6. De-Clercq, E., A. Holy, I. Rosenberg, T. Sakuma J. Balzarini, and P. C. Maudgal. 1986. A novel selective broad-spectrum ariti-DNA virus agent. Natzwe 323:464-467.

7. De-Clereq, E., T. Sakuma, M. Baba, R. Pauwels, J. Balzarini, J. Rosenberg, and A. Holy. 1987. Antiviral activity of phosphonylmethoxyalkyl derivatives of purine and pyrimidines. Antiviral. Res. $8: 261-272$,

8. Gehan, E. 1956. Generalized Wilcoxon test for comparing arbitrarily single sensored samples. Biometrica 52:203-224.

9. Ho, H. T., K. L. Woods, J. J. Bronson, H. De-Boeck, J. C. Martin, and M. J. Hitchcock. 1992. Intracellular metabolism of the antiherpes agent (S)-1-[3-hydroxy-2-(phosphonylmethoxy)propyl]cytosine. Mol Pharmacol 41:197-202.

10. Ho, M. 1991. Cytomegalovirus. Biology and Infection. Plenum Medical Book Company, New York. $440 \mathrm{pp}$. 
11. Hóly, A., I. Votruba, A. Merta, J. Cerny, J. Vesely, J. Vlach, K. Sediva, 1. Rosenberg, M. Otmar, H. Hrebabecky, et al. 1990. Acyclic nucleotide analogues: synthesis, antiviral activity and inhibitory effects on some cellular and virus-encoded enzymes in vitro. Antiviral. Res. 13:295-311.

12. Li, S. B., Z. H. Yang, J. S. Feng, C. K. Fong, H. L. Lucia, and G. D. Hsiung. 1990. Activity of (S)-1-(3-hydroxy-2-phosphonylmethoxypropyl)cytosine (HPMPC) against guinea pig cytomegalovirus infection in cultured cells and in guinea pigs. Aniwiral. Res. 13:237.252.

13. Macher, A. M., C. M. Reichert, S. E. Straus, D. L. Longo, J. Parrillo, H. C. Lane, A. S. Fauci, A. H. Rook, J. F. Manischewitz, and G. V. Quinnan Jr. 1983. Death in the AlDS patient: role of cytomegalovirus [letter]. N. Engl. J. Med. 309:1454.

14. Meijer, H., P. H. Dormans, J. L. Geelen, and C. P. van-Boven. 1984. Rat cytomegalovinus: studies on the viral genome and the proteins of wirions and nucleocapsids. If. Gen. Virol 65 (Pt 4):681-695.

15. Mills, $J$, and L. Corey. 1986. Antiwiral therapy: new directions for climical application and research. Elsevier Science Publishing, inc., New York. 195-203 pp.

16. Neyts, J., and E. De-Clercq. 1594. Mechanism of action of acyclic nucleoside phosphonates against herpes virus replication. Biachem. Pharmacol 47:39-41.

17. Quinnan, G. V., Jr, H. Masur, A. H. Rook, G. Amstrong, W. R. Frederick, 1. Epstein, J. F. Manischewitz, A. M. Macher, L. Jackson, J. Ames, et al. 1984. Herpesvirus intections in the acquired immune deficiency syndrome. Jama. 252:72-77.

18. Snoeck, R., T. Sakuma, E. De-Clerch, I. Rosenberg, and A. Holy. 1988. (S)-1-(3-hydroxy-2-phosphonylmethoxypropyl)cytosine, a potent and selectiwe inhibitor of human cytomegalovirus replication. Antimicrob. Agents. Chemather. 32:1839-1844.

19. Stals, F. S., F. Bosman, C. P. vam-Boven, and C. A. Bruggeman. 1990. An animal model for therapeutic intervention studies of CMV infection in the immunocompromised host. Arch Virol. 114:91-107.

20. Votruba, I., R. Bernaerts, T. Sakuma, E. De-Clercq, A. Merta, I. Rosenberg, and A. Holy. 1987. Intracellular phosphorylation of broad-spectrum anti-DNA virus agent (S)-9-(3-hydroxy-2-plosphonylmethoxypropyl)adenine and inhibition of wiral DNA synthesis. Mol. Phormacol. 32:524-529. 


\section{4}

\section{Rat cytomegalovirus-induced pneumonitis after allogeneic bone marrow transplantation: effective treatment with (S)- 1-(3-hydroxy-2-phosphonylmethoxypropyl)cytosine}

\section{Summary}

Two antiviral compounds, (S)-1-(3-hydroxy-2-phosphonylmethoxypropyl)cylosine (HPMPC) and 9-(1,3-dihydroxy-2-propoxymethyl)guanine (DHPG) were evaluated for their effects on rat cytomegalovirus (RCMV)-induced interstitial pneumonitis after allogeneic bone marrow transplantation (BMTx). Eight-week-old Brown Norway rats immunosuppressed by a lethal dose of total body irradiation were inoculated with RCMV and received allogeneic bone marrow cells from Lewis rats. Animals were treated with either HPMPC ( $20 \mathrm{mg} / \mathrm{kg}$ of body weight as a single dose) or DHPG $(20 \mathrm{mg} / \mathrm{kg}$ as two daily doses for 5 days). The effect of antiviral therapy was monitored by measuring RCMV titres in different organs and the histopathologic changes in lungs at 8 to 10 days post infection. In RCMV-infected allogeneic bone marrow transplant (BMT) recipients, severe diffuse thickening of alveolar septa $(6.02$ $\mu \mathrm{m})$ with a diffuse infiltration of mononuclear cells occurred, whereas in the non-infected allogeneic BMT recipients, the septal. width was in the order of $2 \mu \mathrm{m}(P<0.01)$. Treatment with DHPG (20 $\mathrm{mg} / \mathrm{kg}$ in two daily doses for 5 days) resulted in a decrease in virus titres ( $\log _{10}$ PFU per gram of tissue) in lungs and spleens from $3.8 \pm 0.34$ and $4.29 \pm 1.07$ (untreated animals) to $1.26 \pm 0.53$ and $3.22 \pm 0.27$ (treated animals), respectively. Treatment with HPMPC (20 mg/kg as a single dose) resulted in a complete reduction of virus titres in all organs to below the detection level $(P<0.01)$. Furthermore, antiviral treatment resulted in a reduction of the alveolar septal width from $6.02 \pm 1.59 \mu \mathrm{m}$ (untreated animals) to $4.67 \pm 1.70$ and $3.32 \pm 0.63 \mu \mathrm{m}$ after DHPG and HPMPC treatment, respectively. Furthermore, the influx of mononuclear cells in the alveolar septa was significantly impaired after treatment with HPMPC $(P<0.01)$. We conclude that in the deseribed rat model, HPMPC is highly effective in suppressing RCMV-induced interstitial pneumonitis after allogeneic BMTX. 


\section{Introduction}

Cytomegalovirus (CMV) occurs in about 50 to $60 \%$ of patients after organ and bone marrow transplantation (BMTx) (1,21). After allogeneic BMTx, CMV-induced interstitial pneumonitis (IP) is observed in 15 to $18 \%$ of the cases and represents a major cause of death, with a mortality rate of up to $83 \%(16,35)$.

Ganciclovir combined. with immunoglobulin reduces human CMV pneumonitis mortality in bone marrow transplant (BMT) recipients $(12,19,23)$, and administration at the time that wiral shedding is identified reduces the subsequent risk at CMV disease $(14,18)$. However, the clinical use of this agent is limited by adverse reactions (9). Moreover, treatment of IP after allogeneic BMTX remains a major clinical problem, partly because of the poor understanding of the pathogenesis of CMV-induced IP $(25,27)$ and partly because of the unavail. ability of potent and selective inhibitors of human CMV replication in vivo (2). Recently, a new class of acyclic nucleoside phosphonate analogs has been described $(10,11,34)$. Of these compounds, (S)-1-(3-hydroxy-2-phosphonylmethoxypropyl)cytosine (HPMPC) seems to be the most potent and most selective inhibitor of CMV replication in vitro (29). In the treatment of generalized rat CMV (RCMV) infection in immunocompromised rats, HPMPC appears to be far more effective than 9-(1,3-dihydroxy-2-propoxymethyl)guanine (DHPG) (31).

To study new therapeutic approaches for the treatment of CMV-induced IP, an animal model resembling the human situation is required. Using RCMV isolated from wild rats, we developed an animal model for generalized CMV infections in immunocompromised rats (6, 30). In immunocompetent rats CMV infections are asymptomatic. In immunocompromised rats, however, diseases including hepatitis, splenitis and thrombocytopenia occurs. We have studied the pathologic and virologic course of $\mathrm{CMV}$-induced interstitial pneumonitis after allogeneic BMTx in rats and determined the effect of antiviral strategies with HPMPC and DHPG on these parameters.

\section{Materials and methods}

\section{Animals}

Eight-week-old inbred specified pathogen-free (SPF) male Brown Norway (BN) rats witl a total body weight between 140 to $180 \mathrm{~g}$ were used as recipients of BMTx. As donors for allogemeic bone marrow cells adult SPF Lewis rats were used and syngeneic bone marrow cells were harvested from adult BN rats. By using an enzyme immuno assay according to the method of Engvall et al. (13) neither donor animals nor recipients had antibodies to CMV at the start of the experiment. All rats were bred and housed at the Department of Experimental Animal Services at the University of Limburg, Biomedical Center, Maastricht, The Netherlands. All animal experiments were approved by the university ethical committee for animal studies. 


\section{RCMV infection and total body irradiation}

The RCMV stack consisted of a pool of salivary glands harvested from acutely infected laboratory rats (6). The salivary glands were homogenized and the supernatant was collected after centrifugation and stored at $-70^{\circ} \mathrm{C}$. Each rat received from the RCMV stock $10^{5}$ plaque forming units (PFU) by intraperitoneal route (i.p.) as described before (5). For immunosuppression animals received 9.6 Gray (Gy) total body X-irradiation (TBI) one day before inp. RCMV inoculation (7).

\section{Bone marrow transplantation}

Syngeneic and allogeneic bone marrow cells from donors were obtained as described earlier (3). One day after TBI and $6 \mathrm{~h}$ post infection (p.i.) each rat received $5 \cdot 10^{7}$ viable bone marrow cells intravenously.

To prevent bacterial infections with potential pathogenic bacteria after TBI, the aerobically growing Gram negative bacteria were eliminated from the intestines by selective bowel decontamination (SBD) (36). Therefore, BMT recipient rats received one week before transplantation $0.2 \mathrm{ml}$ of a $10 \%$ solution enrofloxacin (a fluoroquinolone) per litre drinking water (Bayer, Mijdrecht, the Netherlands), resulting in a final dose of approximately 2 $\mathrm{mg} / \mathrm{kg} /$ day (32). From the start of SBD all the recipient rats were kept in sterile cages and received sterile food to avoid bacterial infections. Control bacterial faeces cutures proved that the Gram negative aerobic bowel flora was completely eliminated at the time of BMTX.

\section{Experimental design}

The study consisted of two parts, the first being an evaluation of the description of the pathologic events in RCMV infection after allogeneic BMTx compared with that in syrgeneic $B M T$ recipients. The second part consisted of the antiviral treatment of CMV infection after allogeneic BMTx. For allogeneic BMTx bone marrow cells from Lewis rats were administered to BN recipients (group 1); for syngeneic BMTX bone marrow cells from BN rats were administered to BN recipients (group 2). Non-infected allogeneic control rats were also included into the study (group 3).

Antiviral treatment was performed with optimal dosage schedules, as determined earlier (31). DHPG was obtained from Syntex Inc, Palo Alto, California and HPMPC was synthesized by I. Rosenberg and A. Hóly (Czechoslovak Academy of Sciences, Prague, Czechoslovakia) (17). Antivirals were dissolved in sterile phosphate buffered salt solution, $\mathrm{pH} 7.40$ (PBS) and administered to the animals as described below.

DHPG $20 \mathrm{mg} / \mathrm{kg} /$ day was administered to CMV-infected allogeneic BMT recipients by i.p. route in two daily doses for 5 days, starting at 6 h p.i. (group 4) and HPMPC was administered in one single dose 6 hours p.i. (group 5).

Animals were checked every day for physical sigms of symptomatic disease, such as tachypnea, dyspnea as signs for lung involvement, ocular discharges, brushy hairs, and impaired 
reactivity to exogenous stimuli as signs for generalized infection and hunchback as a sign for peritonitis (30). From about 8 days post infection and judged on the criteria mentioned above, rats were examined, and just before untreated rats died (group 1 and 2) all groups were sacrificed on the same day (between day 8 and 10 p.i.). Then, lungs, spleen, liver, kidney and salivary glands were resected and processed for histological examination and virus plaque assays as described earlier $(6,30)$. Briefly, samples of salivary glands, spleen, liver and lungs were homogenized within $3 \mathrm{~h}$ after resection and serial 10 -fold dilutions of a $1: 10$ (w/v) organ suspension in Eagle"s Minimal Essential Medium (MEM) were cultured on rat embryonal fibroblasts (REFs) and the amount of virus was expressed as the logarithm of PFU per gram tissue.

\section{Histological examination}

Samples of the above mentioned organs were lixed in paraformaldehyde-lysine-periodate (PLP) and embedded in paraffin. Serial $3.5 \mu \mathrm{m}$ thick sections were prepared for hematoxylineosin (HE) staining, Jones silver staining and immunoperoxidase staining using monoclonal antibodies to RCMV antigens as described below. For morphometric analyses the thickness of the alveolar wall was measured 10 times for each lung by two different observers. There was a high agreement between the two series of measurements $(P>0.95)$. For final analysis the mean of 20 measurements from one rat was used. The amount of inflammatory infiltrate in alveolar septa and alveolar spaces was assessed semi-quantitatively in each section. Absence of inflammatory cells was scored as 0 , slight inflammatory infilltrate as 1 , moderate dense infiltrate as 2 , and dense inflammatory infiltrate as 3 (see table. 2)

\section{Immunohistochemistry}

After deparaffinization sections were blocked for their endogenous peroxidase activity by incubation in $100 \%$ methanol, containing $0.3 \% \mathrm{H}_{2} \mathrm{O}_{2}$ for $30 \mathrm{~min}$ and preincubated for $30 \mathrm{~min}$ at room temperature with $10 \%$ normal rabbit serum and washed with $\mathrm{PBS}+0.05 \%$. Tween 20 and then incubated for $1 \mathrm{~h}$ in moisted air (30) with a mouse monoclonal antibody (McAb), termed as McAb 35 and directed against the $29 \mathrm{kDa}$ early structural antigen of RCMV and giving a specific diffuse nongranular staining in the cytoplasma of CMV-infected cells (8). The sections were washed and incubated with biotinylated, affinity-purified sheep anti-mouse Ig (Amersham Nederland B.V., Houten, The Netherlands) 1:200 in PBS containing 1\% bovine serum albumine (BSA) for $60 \mathrm{~min}$, followed by washing and incubation with biotin-streptavidin-horseradish peroxidase complex (Amersham) 1:400 in PBS containing 1\% of BSA for $45 \mathrm{~min}$, washed again and incubated for $10 \mathrm{~min}$ in diaminobenzidine (DAB) in PBS with $\mathrm{H}_{2} \mathrm{O}_{2}$ and, after washing, counterstained with hematoxylin, dried and embedded in Entellan (30). 
Table 1. Virus hitres in organs of rats after BMTx with or withont antiviral treatment".

\begin{tabular}{|c|c|c|c|c|c|c|c|c|}
\hline \multirow[b]{2}{*}{ Group } & \multirow[b]{2}{*}{ BMTx } & \multirow[b]{2}{*}{ Treatment } & \multirow[b]{2}{*}{ (n) } & \multicolumn{5}{|c|}{$\log _{10}$ PFU/g of tissue } \\
\hline & & & & Lungs & Spleen & Liver & Kidney & $\begin{array}{l}\text { Salivary } \\
\text { glands }\end{array}$ \\
\hline 1 & Allogeneic & None & $(12)$ & $3.81 \pm 0.34$ & $4.29 \pm 1.07$ & $3.26 \pm 1.13$ & $2.14 \pm 0.62$ & $1.94 \pm 0.74$ \\
\hline 2 & Syngeneic & Nane & (8) & $4.08 \pm 0.22$ & $3.93=0.16$ & $4.56 \pm 1.32$ & $2.40 \pm 1.22$ & $1.13 \pm 1.15$ \\
\hline 4 & Allogeneic & $\mathrm{DHPG}^{\mathrm{b}}$ & (11) & $1.26 \pm 0.53^{\mathrm{t}}$ & $3.22 \pm 0.27$ & $2.42 \pm 0.46$ & $2.37 \pm 0.46$ & $2.80 \pm 0.55$ \\
\hline 5 & Allogeneic & HPMPC & (11) & $<1.25$ & $<1.25$ & $<1.25$ & $<125$ & $<1.25$ \\
\hline
\end{tabular}

${ }^{a}$ Groups of at least five BN rats each received 9.6 Gy of TBI and $5 \cdot 10^{7}$ viable allogeneic (Lewis) or syngeneic (BN) bone marrow cells at 2 hours before inoculation with $10^{5}$ PFU of RCMV i.p. Ongans were harvested at 8 days p.i. Data represent two separate experiments.

${ }^{6} \mathrm{DHPG}$ at $20 \mathrm{mg} / \mathrm{kg} /$ day twice daily for 5 days starting $6 \mathrm{~h}$ p.i.

\& $P<0.01$, compared with group 1 .

${ }^{d}$ HPMPC $20 \mathrm{mg} / \mathrm{kg}$ as a single dose at $6 \mathrm{~h}$ p.i.

\section{Statistical analysis}

For statistical analysis the chi-square test and Mann-Whitney tests were used. $P$-values $<0.01$ were considered significant. For interobserver analyses the paired Student's-t-test was used.

\section{Results}

\section{Characterization of RCMV pneumonitis model}

About 8 days after allogeneic BMTx and RCMV inoculation, the virus reach maximum titres (4.29 $\pm 1.07 \log _{10} \mathrm{PFU} / \mathrm{g}$ tissue) in the spleen of rats, which then suffer all from symptomatic RCMV disease (group 1) . However, in lungs, liver and kidney RCMV titres were 0.5-2.0 $\log _{10} \mathrm{PFU} / \mathrm{g}$ lower. After syngeneic BMTX and subsequent RCMV inoculation (group 2), virus titres in spleen, lungs, liver and kidney were comparable (table 1). RCMV titres in salivary glands of both groups were near the detection level ( $\log _{10} 1.25 \mathrm{PFU} / \mathrm{g}$ ).

All untreated RCMV-infected rats (group 1) showed severe symptoms of infection, such as ocular discharge, hunchback and impaired reactivity to exogenous stimuli. In contrast to syngeneic RCMV-infected recipients (group 2), animals which received allogeneic BMTXX (group 1) showed severe tachypnea and dyspnea shortly before dying. Furthermore, group I animals had haemorrhagic fluid in their peritoneum and petechiae and ecchymoses on the liver and spleen, findings already described for immunocompromised RCMV-infected rats without BMTX (30). In addition many of the group 1 animals showed haemorrhagic lesions in the lungs. Lungs of RCMV-infected allogeneic BMT recipients (group 1) showed dilatation of alveolar vessels, alveolar edema and infiltration of alveolar stroma with mononuclear (MN) cells, (figure 1). As shown in table 2, severe thickening of the alveolar septa was noted in 


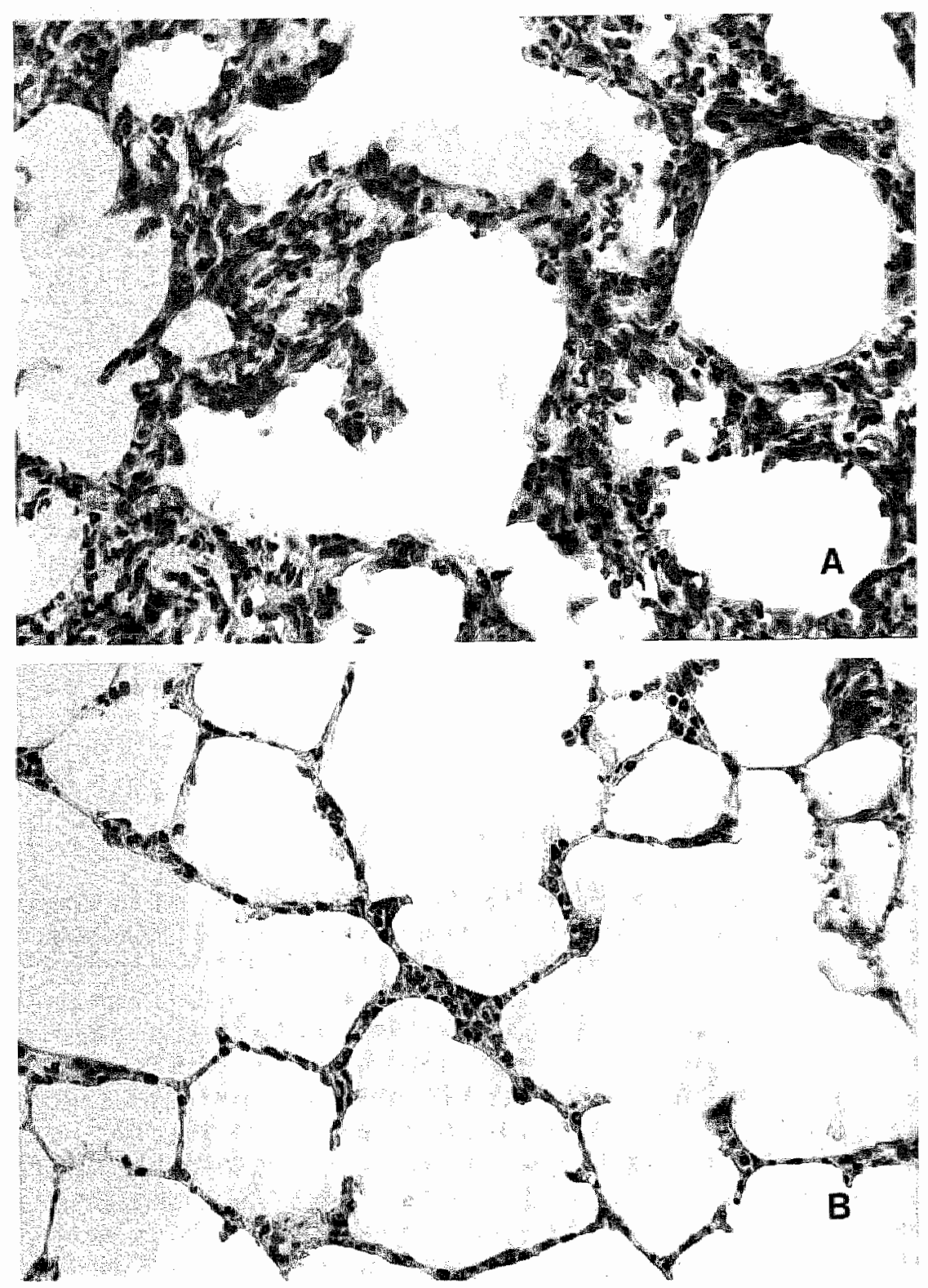

Figure 1. HE staining of lung sections from rats, 8 days after allogeneic BMTX and subsequent RCMV infection. A: lung section from untreated animal: The alveolar septa were severely thickened and the alveolar stroma was infiltrated with mononiclear cells; B: lung section of HPMPC treated rat: The thickness of alveolar septal wall. is reduced to nomal size. The alveolar stroma is infiltrated with only few mononuclear cells. 
Table 2. Lung pathology in rats after BMTx with or without antiviral treatmerrt"

\begin{tabular}{|c|c|c|c|c|c|c|c|c|}
\hline \multirow{2}{*}{\multicolumn{2}{|c|}{ Group BMTX }} & \multirow[b]{2}{*}{ Infection } & \multirow[b]{2}{*}{ Treatment } & \multirow[b]{2}{*}{ (n) } & \multirow{2}{*}{$\begin{array}{l}\text { Alweolar } \\
\text { septum } \\
\text { thickness } \\
(\mu m)^{b}\end{array}$} & \multicolumn{3}{|c|}{ Histopathology score } \\
\hline & & & & & & $\begin{array}{l}\text { Mononuclear } \\
\text { cell }\end{array}$ & $\begin{array}{l}\text { Alveolar } \\
\text { macrophage }\end{array}$ & Edema \\
\hline 1 & Allogeneic & RCMV & None & $(22)$ & $6.02 \pm 1.59$ & $2.8 \pm 0.4$ & $1.4 \pm 0.9$ & $1.8 \pm 1.1$ \\
\hline 2 & Syngeneic & RCMV & None & (8) & $2.45 \pm 0.36^{\mathrm{d}}$ & $2.3 \pm 0.6$ & $0.7 \pm 1.1$ & $1.7 \pm 1.2$ \\
\hline 3 & Allogeneic & None & None & (8) & $1.85 \div 0.23^{d \mathrm{~d}}$ & $1.0 \pm 0.0^{d}$ & $0^{\mathrm{d}}$ & $0.7 \pm 1.2$ \\
\hline 4 & Allogeneic & RCMV & $\mathrm{DHPG}^{\mathrm{e}}$ & (11) & $4.67 \pm 1.7$ & $2.4 \pm 0.9$ & $1.4 \pm 1.3$ & $1.6 \pm 0.9$ \\
\hline 5 & Allogeneic & RCMV & $\mathbb{H P M P C}$ & (11) & $3.32 \pm 0.63^{d}$ & $1.0 \pm 0.0^{\mathrm{d}}$ & $1.2 \pm 0.5$ & $1.2 \pm 0.4$ \\
\hline
\end{tabular}

${ }^{a}$ Groups of at least five BN rats each received 9.6 Gy TBI and $5 \cdot 10^{7}$ viable allogeneic (Lewis) or syngeneic (BN) bone marrow cells at $2 \mathrm{~h}$ before inoculation with $10^{5}$ PFU RCMV i.p. Lungs were harvested at 8 days p.i. Data represent two separate experiments.

"The alveolar septa from each rat were measured 10 times by two independent observers. Fach number represents the mean \pm standard deviation for these measurements in six rats. The presence of cells, wasculir congestion and edema were scored on a scale from 0 (absent) to 3 (maximum).

"The presence of cells, vascular congestion, and edema was scored on a scale from 0 (absent) to 3 (maximum).

$p<0.01$.

"DHPG at $20 \mathrm{mg} / \mathrm{kg} /$ day twice daily for 5 days starting at 6 hours p.i.

${ }^{r}$ HPMPC at $20 \mathrm{mg} / \mathrm{kg}$ as a single dose at 6 hours p.i.

group 1, compared with non-infected allogeneic controls (group 3). In the untreated RCMVinfected syngeneic BMT recipients (group 2) thickening of the alveolar septa occurred to a far lesser extent compared with the allogeneic BMT recipients (group 1) $(P<0.01$ ). The inflammatory infiltrate was more focally located and edema was less pronounced or even absent in the syngenic BMT recipients compared with the allogeneic BMTX group.

In the untreated RCMV-infected allogeneic BMT recipients (group 1) numerous alveolar lining cells and alveolar macrophages showed cytoplasmatic immunoreactivity to CMV antigens. RCMV antigen was also found in large amounts in spleen and liver and to a lesser extent in kidney and in some of the salivary glands. RCMV-infected syngeneic BMT recipients (group 2) showed similar findings.

\section{Effect of antiviral treatment}

As shown in table 1, antiviral treatment resulted in a significant decrease in RCMV uitres in lungs from DHPG-treated (group 4) and from HPMPC-treated animals (group 5) compared to untreated rats, $(P<0.01)$. However, following DHPG treatment virus titres in the spleen and liver decreased only slightly and not significantly. After HPMPC treatment no virus was detected in spleen, lungs or any of the other organs $(P<0.01)$.

As compared to the thickness of alveolar septa $(1.85 \pm 0.23 \mu \mathrm{m})$ in untreated rats after allogeneic BMTx without RCMV infection (group 3), and after syngeneic BMTx with RCMV infection (group 2) the thickness of the septa was almost identical $(2.45 \pm 0.36 \mu \mathrm{m}$ ), but the 


\section{Chapter 4}

widh was increased compared with that of the alveolar septa of normal heal thy rats $( \pm 1.0 \mu \mathrm{m}$, data not shown). However, in rats which received allogeneic BMTX and RCMV both (group 1), alveolat septa were extremely thickened $(6.02 \pm 1.59 \mu \mathrm{m})$. Treatment with DHPG reduced thickness of alveolar septa only slightly, but HPMPC treatment led to complete reduction of the alveolar wall. As shown in table 2, DHPG and HPMPC treatment also reduced the amount of inflammatory infiltration in particular, HPMPC suppressed mononuclear cell (MN) infiltration in lung tissue.

\section{Discussion}

In this rat model CMV infection led to IP in allogeneic BMT recipients. A significant difference in lung pathology was observed between allogeneic and syngeneic BMT recipients, despite comparable infectious virus titres in both host groups. After acute CMV infection the lungs of allogeneic BMT recipient rats showed a prominent influx of MN cells. Perivascular infiltrates with MN cells were frequent in both allogeneic and syngeneic BMT recipients. Compared to non-infected allogeneic BMT recipients, RCMV-infected recipients showed severe thickening of the alveolar septa. However, alveolar septa were not thickened in rats after syngeneic BMTx.

These findings are in accord with the findings of Grundy et. al. (15), who reported that in a model for pneumonia in immunocompetent $F_{\|}$mice severe diffuse type pneumonia occurred only when acute graft (allogeneic spleen cells) versus host reaction in addition to $\mathrm{CMV}$ infection were present. Syngeneic spleen cells, however, did not induce diffuse type pneumomia. Despite high incidence of CMV infection after syngeneic BMTx in man, IP occurs very infrequently (1). Two factors appear to be necessary for the occurrence of CMV-induced IP: active CMV infection and allogeneic cells. However, the mechanism by which IP is induced remains unclear.

As pointed out in previous studies, the control of CMV unfection is mainly based on T-cell immunity (22), and this immunity is restricted by major histocompatibility complex class I $(24,33)$. Therefore, after allogeneic BMTx, major histocompatibility complex class I restricted control of CMV infection seems to be impaired.

Treatment of CMV-induced IP after allogeneic BMTx renains a major clinical problem (9). DHPG, at this moment the most potent therapeutic agent available for treatment of $\mathrm{CMV}$ infections in man, gives poor results for the treatment of CMV-induced IP after allogeneic BMTX (2). In the present study the effect of DHPG treatment on the thickness of the alveolar septa and the amount of perivascular infiltrates was insignificant despite a significant reduction in RCMV titres in the lung and other tissues. Similar results were described in mice (26) and in humans who received DHPG treatment for IP (28). An explanation for this finding could be that CMV-induced IP is an immunopathological process and therefore antiviral treatinent may not expected to be (very) effective (28), or the reduction in virus titres is only partial and therefore protection from CMV-induced IP was incomplete. 
In an attempt to answer these questions, we treated the rats with HPMPC, which has previously been proven to be a very potent and selective inhibitor of RCMV infections in vitro and in vivo (31). In contrast to DHPG HPMPC, which eliminated RCMV completely from lungs and other internal organs, reduced the thickness of the alveolar septa almost completely $(P<0.01)$. Taken together, these observations suggest that, when virus is absent (e.g. below detection level) in any internal organ immunopathologic findings in the Lungs do not ensue. Therefore, it is postulated that some degree of active CMV replication and presentation of viral antigens (not necessarily originating in the lungs) is obligatory to produce CMV-induced IP.

One single dose of HPMPC, administered early after infection prevented completely CMVinduced IP. This drug has the advantage over DHPG that it has a 10-fold higher selectivity and potent activity against CMV (whether rat, mouse or human) in vitro and that it is also far more potent then DHPG against both rat CMV (31) and murine CMV (20) in vivo. Toxicity studies for I-TPMPC in mice failed to detect toxicity at 200 and $400 \mathrm{mg} / \mathrm{kg}$, respectively (4, 10), which is in the same order as the lethal dose for DHPG in these animals. In rats dosages of $300 \mathrm{mg} / \mathrm{kg}$ for 3 days were not toxic (31). Phase 1 studies in man will be performed soon. In conclusion, HPMPC is far more active against RCMV-induced IP then DHPG, and HPMPC can be considered as a very promising candidate drug for the treatment of CMV-induced IP in allogeneic BMT recipients.

\section{References}

1. Applebaum, F. R., J. D. Meyers, A. Fefer, N. Fluornoy, M. A. Cheever, P. D. Greenberg, R. Hackman, and E. D. Thomas. 1982. Nonbacterial nonfungal pneumonia following marrow transplantation in 100 identical twins. Transplantation. 33:265-268.

2. Balfour, H. H., Jr. 1990. Management of cytomegalovirus disease with antiviral drugs. Rev. Infect. Dis. 12 (Suppl. 7):S849-S860.

3. Bos, G. M., G. D. Majoor, C. A. Bruggeman, G. Grauls, M. J. van-de-Gaar, and P. J.1989. Rat cytomegalovirus can be transferred by bone marrow cells but does not affect the course of acute graft-versus-host disease. Transplant. Proc. 21 (Pt 3):3050-3052.

4. Bronson, J. J., I. Ghazzouli, M. J. Hitcheock, R. R. Webb 2d., and J. C. Martin. 1989. Synthesis and antiviral activity of the nucleotide analogue (S)-1-[3-hydroxy-2-(phosphony/methoxy)propyl]cyto" sine. J. Med. Chem. 32:1457-1463.

5. Bruggeman, C. A., W. M. Debie, G. Grauls, G. Majoor, and C. P. van-Boven. 1983. Infection of laboratory rats with a new cytomegalo-like virus. Arch. Virol. 76:189-199.

6. Bruggeman, C. A., H. Meijer, P. H. J. Dormans, W. M. H. Debie, G. E. L. M. Grauls, and C. P. A. van Boven. 1982. Isolation of a cytomegalowirus-like agent from wild rats. Arch. Virol. 73:231-241.

7. Bruning, J. H., C. A. Bruggeman, C. P. van-Boven, and P. J. van-Breda-Vriesman. 1986. Passive transfer of cytomegalovirus by cardiac and renal organ transplants in a rat model. Transplantation. 41:695-698.

8. Bruning, J. H., W. H. Debie, P.H. Dormans, H. Meijer, and C. A. Bruggeman. 1987. The development and characterization of monoclonal antibodies against rat cytomegalovirus induced antigens. Arch. Virol 94:55-70. 
9. Collaborative DHPG Treatment Sudy Group. 1986. Treatment of serious cytomegalowinu infections with $9-(1,3-d$ dhydroxy-2-propoxymethyl)guanine in patients with AIDS and ather imumurodeficiencies. M. Engl J Med 314:801-805.

10. De-Clercq, E., A. Holy, I. Rosenberg, T. Sakuma, J. Balzarini, and P. C. Maudgal. 1986. A novel selective broad-spectrum anti-DNA wirus agent. Nature. 323:464-467.

11. De-Clerca, E., T. Sakuma, M. Baba, R. Pauwels, J. Balzarini, I. Rosenberg, and A. Holy, 1987. Antiviral activity of phosphonylmethoxyalkyl derivatives of purine and pyrimidines. Antrival. Res. 8:261-272.

12. Emanue ${ }_{n} D_{r p}$ I. Cinningham, K. Jules-Elysee, J. A. Brochstein, N. A. Kernan, J. Lawer, D. Stover, D. A. White, A. Fels, B. Polsky, H. Castro-Malaspina, J. R. Peppard, P. Bartus, U. Hammerling, and R. J. O'Reilly. 1988. Cytomegalowirus pneumonia after bone marrow transplantation successfully treated with the combination of ganciclovir and high-dose intravenous immune globulin. Ann. Intern. Med. 109:777-782.

13. Engvall, E., and P. Perlinann. 1972. Enzyme-linked immunosorbent assay, ELISA. J. Immunol. 109:129-135.

14. Goodrich, J. M., M. Mori, C. A. Gleaves, C. Du-Mond, M. Cays, D. F. Ebeling, W. C. Buhles, B. DeArmond, and J. D. Meyers. 1991 . Early treatment with ganciclovir to prevent cytomegalowirus disease after allogeneic bone marrow transplantation. N. Engl. J. Med. 325:1601-1607.

15. Grundy, J. E., J. D. Shanley, and G. M. Shearer. 1985 . Augmentation of graft-wersus-host reaction by cytomegalowirus infection resulting in interstitial pneumonitis. Transplantation. 39:548-553.

16. Ho, M. 1991 . Cytomegalovirus. Biology and Infection. Plenum Medical Book Company, New York. 440 pp.

17. Holy, A., I. Votruba, A. Merta, J. Cerny, J. Vesely, J. Vlach, K. Sediva, I. Rosenberg, M. Otmar, H. Hrebabecky, et al. 1990. Acyclic nucleotide analogues: synthesis, antiviral activity and inhibitory effects on some cellular and virus-encoded enzymes in vitro. Antiviral. Res. 13295-311.

18. L.jungman, P., D. Engelhard, H. Link, P. Biron, L. Brandt, S. Brunet, C. Condonnier, L. Debusscher, A. de-Laurenzi, H. J. Kolb, C. Messina, A. C. Newland, H. G. Prentice, C. Richard, T. Ruutu, H. Tilg, and L. Verdonck. 1992. Treatment of interstitial pneumonitis due to cytomegalovirus with ganciclovir and intravenous immune globulin: experience of European Bone Marrow Transplant Group. Cin. Infect. Dis. 14:831-835.

19. Mills, J., and L. Corey. 1986. Antiviral therapy: new directions for clinical application and research. Elsevier Sclence Publishing, inc., New York. 195-203 pp.

20. Neyts, J., J. Balzarini, L. Naesens, and E. De-Clercq. 1992. Efficacy of (S)-1-(3-hydroxy-2-phosphonylmethoxypropyl)cytosine and 9-(1,3-dihydroxy -2-propoxymethyl)guanine for the treatment of murine cytomegalowirus infection in severe combined immunodeficiency mice. $J$. Med. Virol. 37:67-71.

21. Rasing, L. A., R. A. De-Weger, L. F. Verdonck, W. van-der-Bij, P. Il. Compier-Spies, G. C. De-Gast, C. D. Van-Basten, and H. J. Schuurman. 1990. The value of immunohistochenistry and in situ lhybridization in detecting cytomegalovirus in bone marrow transplant recipients. Apmis. 98:479-488.

22. Reddehase, M. J $J_{w}$ F. Weiland, K. Münch, S. Jonjic, A. Lüske, and U. H. Koszinowski. 1985. Interstitial murine cytomegalovirus pneumonia after irradiation: characterization of cells that limit viral replication during established infection of the lungs. J. Virol. 55:264-273.

23. Reed, E. C., R. A. Bowden, P. S. Dandliker, K. E. Lilleby, and J. D. Meyers. 1988. Treatment of cytomegalovirus pneumonia with ganciclov ${ }^{\sharp}$ and intravenous cytomegalovirus immunoglobulin in patients with bone marrow transplants. Ann. Interm. Med. 109:783-788. 
24. Riddell, S. R., M. Rabin, A.P. Geballe, W. J. Britt, and P. D. Greenberg 1991. Class I MHC-restricted cytotoxic $T$ lymphocyte recognition of cells infected with human cytomegalovirus does not require endogenous wiral gene expression. $J$. Immunol. 146-2795-2804.

25. Shanley, J. D., E. L. Pesanti, and K. M. Nugent. 1982. The pathogenes is of pneumonitis due to murine cytomegalovirus. J. Inf. Dis. 146:388-396.

26. Shanley, J.D., C. Porneroy, C.S. Via, and G. M. Shearer. 1988. Interstitial pneumonitis during murine cytomegalowirus infection and graft-versus-host reaction: effect of ganciclowir therapy. $J$. Iffect. Dis. 158:1391-1394.

27. Shanley, J. D., C. S. Via, S. O. Sharrow, and G. M. Shearer. 1987. Interstitial preumonitis during marine cytomegalovirus infection and graft-versus-host reaction. Characterization of bronchoalveolar lavage cells. Transplantation. 44:658-662.

28. Shepp, D. H., P. S. Dandliker, P. de-Miranda, T. C. Burnette, D. M. Cederberg, L. E. Kirk, and J. D. Meyers. 1985. Activity of 9-[2-hydroxy-1-(hydroxymethyl)ethoxymethyl]guanine in the treatment of cytomegalovirus pneumonia. Ann. Intern. Med 103:368-373.

29. Snoeck, R., T. Sakuma, E. De-Clercq, I. Rosenberg, and A. Holy. 1988. (S)-1-(3-hydroxy 2-phosphonylmethoxypropyl)cytosine, a potent and selective inhibitor of human cytomegalowirus replication. Antimicrob. Agents. Chemother. 32:1839-1844.

30. Stals, F, S., F. Bosman, C. P. van-Boven, and C. A. Bruggeman. 1990. An animal model for therapeutic intervention studies of $\mathrm{CMV}$ infection in the inmunocompromised host. Arch. Firol. 114:91-107.

31. Stals, F. S., E. de-Clercq, and C. A. Bruggeman. 1991. Comparative activity of (S)-1-(3-hydroxy-2phosphonylmethoxypropyl)cytosine and 9-(1,3-dihydroxy-2-propoxymethyl)guanine against rat cytomegalovirus infection in vitro and in vivo. Antimicrob. Agents. Chemother 35:2262-2266.

32. Vancutsem, P. M., J. G. Babish, and W. S. Schwark. 1990. The fluoroquinolone antimicrobials: structure, antimicrobial activity, pharmacokinetics, clinical use in domestic animals and toxicity. Correll. Vet. 80:173-186.

33. Via, C. S., I. D. Shanley, and G. M. Shearer. 1990. Synergistic effect of murine cytomegalow urus on the induction of acute graft-vs-host disease involving MHC class I differences only. Analysis of in vitro T cell function. $J$. Immunol. 145:3283-3289.

34. Votruba, I., R. Bernaerts, T. Sakuma, E. De-Clercq, A. Merta, I. Rosenberg, and A. Holy. 1987. Intracellular phosphorylation of broad-spectrum anti-DNA virus agent (S)-9-(3-hydroxy-2-phosphonylmethoxypropyl)adenine and inhibition of viral DNA synthesis. Mol. Pharmacol. 32:524-529.

35. Winston, D. J., W. G. Ho, and R. E. Champlin. 1990. Cytomegalovirus infections after allogeneic bone martow transplantation. Rev. Infect. Dis. 12 (Suppl. 7):\$776-\$792.

36. Wolfson, J. S., and D. C. Hooper. 1989. Fluoroquinolone antimicrobial agents. Clin. Microbiol Rev. $2: 378-424$. 


\section{Generalized cytomegalovirus infection and CMV-in- duced pneumonitis in the rat: Combined effect of 9-(1,3- dihydroxy-2-propoxymethyl)guanine and specific antibody treatment}

\section{Summary}

The combined effect of 9-(1,3-dihydroxy-2-propoxymethyl)guanine (DHPG, ganciclovir) and hyper immume serum (HIS) was studied in two different rat models. In the first model, a lethal generalized rat cytomegalovirus (RCMV) infection was established in immunosupressed Brown Norway (BN) rats. Treatment with DHPG or hyper immune serum (HIS) effectively reduced both mortality rate and virus titres in the liver and lungs. By combined treatment the effective dose of both DHPG and HIS was reduced to $25 \%$. The fractionary effective dose was 0.5 , indicating a moderate synergistic effect on survival. Combined treatment also established a significant reduction of virus titres in lungs and liver $(p<0.01)$, but not in spleen. In the second model, interstitial pneumonia (IP) was established in RCMV-infected immunosupressed BN rats after allogeneic bone marrow transplantation. IP was characterized by infiltration of mononuclear cells and diffuse thickening of the alveolar septal wall. DHPG reduced virus titres in the lungs but had no effect on IP. In contrast, WIS significantly reduced both virus titres and histopathologic changes in the lungs. Combined DHPG and HIS treatment minimized virus titres in internal organs and CMV-induced IP. Likewise, combined $D H P G$ and control immune serum treatment significantly reduced immunopathologic changes in the lungs. 


\section{Introduction}

Cytomegalovirus (CMV) has been recognized as one of the most common pathogens causing a wide spectrum of symptoms in immunocompromised patients, depending on the state of the host immunity. In neonates CMV infections are characterized by hepatosplenomegaly, neurologic disorders and thrombocytopenia (22). In patients with the acquired immunodeficiency syndrome (AIDS), CMV-induced retinitis, pneumonia and gastrointestinal ulcers frequently occur (44). In allogeneic bone marrow transplant (BMT) recipients CMV-induced interstitial pneumonia (TP) is an important feature, representing a major cause of death with a mortality rate up to about $80 \%(22,45)$.

Although the clinical use of the agent is limited by adverse reactions $(1,8)$, the antiviral drug, 9-(1,3-dihydroxy-2-propoxymethyl)guanine (DHPG, ganciclovir) has been shown to be therapeutically effective against CMV disease in man $(8,16,34)$. Alternatively, intravenous treatment with hyper immune serum (HIS) containing polyclonal antibodies directed against CMV seems plausible, especially for treatment of CMV-induced IP after allogeneic bone marrow transplantation (BMTX) (36). In addition, several reports about the combined action of HIS and DHPG gave promising results for treatment of CMV-induced pneumonitis (13, $24,30,31$ ). To study the therapeutical approach of CMV infections, we used rat cytomegalovirus (RCMV), isolated and characterized in our laboratory $(6,25)$. Similarly to CMV infections in man, the course of RCMV infections in the immunocompetent host is asymptomatic, but in immunocompromised animals severe generalized infection occurs. Symptoms are characterized by splenitis, hepatitis and thrombocytopenia $(37,38)$. In addition, CMV infection in allogeneic BMT recipient rats results in severe IP (40).

The therapeutical effect of single and combined treatment with DHPG and HIS on lethal generalized RCMV infection was investigated. Finally, the effect of these agents on the development of $\mathrm{CMV}$-induced IP was investigated in an allogeneic BMT model.

\section{Materials and methods}

\section{Viruses}

RCMV was isolated and characterized in our laboratory $(6,25,26)$. For in vitro studies and for the production of HIS, supernatant of RCMV-infected rat embryonal fibroblasts (REFs) was used. For in vivo experiments RCMV was obtained from suspensions of sallivary glands after several in vivo passages (5). Non-infected salivary gland suspensions were used for control experiments.

\section{Antiviral agents}

DHPG (Syntex, Palo Alto, California, USA) was dissolved in sterile phosphate-buffered salt solution (PBS) and administered intraperitoneally (i.p.) at different dosages as indicated. 
HIS was obtained from immunized male specific pathogen-free (SPF) Brown Norway (BN) rats after intradermal inoculation with RCMV as described before (37). Control immune serum (CIS) was prepared by administration of a non-infected REF suspension.

\section{Antiviral activity and cytotoxicity assays}

Plaque inhibition assays were performed as described before (38). In short, 200 plaque forming units (PFU) of RCMV were incubated in basal medium Eagle's (BME) $+2 \%$ new-born calf serum (NCS) on REF monolayers in a 24-wells plate (Costar Europe, Badhoevendorp, The Netherlands) for $1 \mathrm{~h}$ at $37^{\circ} \mathrm{C}$. Then, the medium was replaced by $\mathrm{BME}+2 \%$ NCS containing DHPG in concentrations ranging from 200 to $0.01 \mu \mathrm{g} / \mathrm{ml}$ medium. After mixtures were removed the monolayers were covered with a BME-agarose nixture. After 8 days the monolayers were fixed in formalin $3.7 \%$ in PBS and stained with methylene blue. Experiments were carried out in triplicate. The minimal inhibitory concentration of the compound was expressed as the concentration required to inhibit plaque formation by $50 \%$ $\left(E_{50}\right)$. The $E_{50}$ was estimated from the number of plaques on semi-logarithmic graphs as a function of the concentration of the antiviral compounds.

To test the concentration of neutralizing antibodies in HIS and CIS, the plaque-reduction assay was used (29). In short, 2-fold dillutions of heat-inactivated serum were incubated with 300 PFU RCMV in BME $+2 \%$ NCS for $1 \mathrm{~h}$ at $37^{\circ} \mathrm{C}$. These mixtures were absorbed on a REF monolayer in a 24-wells plate (Costar Europe) for $1 \mathrm{~h}$ at $37^{\circ} \mathrm{C}$ and replaced by a BME-agarose mixture. After 8 days of incubation the number of RCMV-induced plaques was monitored and the neutralization titre was expressed as the serun dilution at which the number of plaques was reduced by $50 \%\left(\mathrm{NT}_{50}\right)$.

The inhibitory effects of DHPG and HIS on REF cell growth were determined as described before (38). The cytotoxic concentration of the compound is expressed as the IC50 or concentration required to reduce cell growth by $50 \%$. The selectivity index corresponds to the ratio of $₫ C_{50}$ for cell growth to the $\mathrm{EC}_{50}$ for $\mathrm{RCMV}$ replication.

\section{Animals and CMV infection}

Eight-week-old inbred SPF male BN rats with a total body weight between 140 to $180 \mathrm{~g}$ were used in all experiments. Adult Lewis and BN rats were used as donors for allogeneic and syngeneic bone marrow cells, respectively. Neither the donor animalss nor the recipients had antibodies to RCMV in their peripheral blood at the start of each experiment, as determined by enzyme immunosorbent assay. Each rat received $10^{5}$ PFU RCMV i.p. as described before (4).

To prevent bacterial infections all animals received enroffoxacin $2 \mathrm{mg} / \mathrm{kg} / \mathrm{day}$ (Baytril(1), Bayer, Mijdrecht, the Netherlands) and acidified drinking water $(39,42)$ during the whole experiment, starting 1 week before the onset of the experiment. Furthermore, all animals were kept in sterile cages and received sterile food.

The experiments were approved by the University Ethical Committee for animal experiments. 


\section{Preparation of donor-bone marrow cells}

Bone marrow cells from donors were prepared as described earlier $(2,40)$. One day after 9.6 Gray (Gy) total body irradiation (TBI) and $6 \mathrm{~h}$ post infection (p.i.) each rat received $5 \cdot 10^{7}$ viable cells intravenously.

\section{Design of the experiment}

In vivo combined treatment of DHPG and HIS was evaluated in two different infection models. In the first model generalized infection was induced by i.p. inoculation with RCMV. For immunosuppression animals received 5.0 Gy TBI 1 day before infection. DHPG treatment (administered intraperitoneally) was started $6 \mathrm{~h}$ p.i. and continued twice daily for 5 days. One $\mathrm{ml}$ of HIS, diluted 2-fold in BME $+2 \% \mathrm{NCS}$, was administered intravenously at $6 \mathrm{~h}$ p.i. To determine the effect of combined treatment, DHPG was administered twice daily for 5 days starting at $6 \mathrm{~h}$ p.i. and HIS was administered in a single dose $6 \mathrm{~h}$ p.i.

The following controls were used: (1) Irradiated RCMV-infected rats, (2) irradiated non-infected animals and (3) RCMV-infected non-irradiated rats. In addition, irradiated RCMV-infected animals, which received undiluted CIS were included into the study.

The effect of (combined) treatment on survival was recorded over a period of 21 days $p . i$. The effect of treatment on virus titres in organs was determined at 8 days p.i., as described earlier (38). For this purpose spleen, liver and lungs were removed aseptically, homogenized in a tissue grinder and suspended in $\mathrm{BME}+2 \% \mathrm{NCS}$ and plaque assays were performed. The amount of virus was expressed as the number of PFU per gram organ tissue.

The in vivo activity of $D H P G$ is expressed as the minimal effective dose or the daily dose at which at least $50 \%$ of the animals survived the lethal infection $\left(\mathrm{ED}_{50}\right)$. In addition, the mean day of death (MDD) was calculated. For histological studies material was processed as described below.

In the second model interstitial pneumonia(IP) was induced in allogeneic BMT recipient rats. One day before RCMV inoculation and BMTx, animals received 9.6 Gy TBI. At the day of infection. RCMV was administered i.p., followed by intravenous administration of freshly harvested viable bone marrow cells (2). DHPG, HIS and combined treatment were administered as described above. Non-infected allogeneic BMT recipients and infected syngeneic BMT recipients were uncluded into the study as well as CIS-treated animals and combined DHPG- and CIS-treated animals.

Rats were examined daily for signs of infections as described elsewhere (38) and survival was recorded. For plaque studies and histopathology, spleen and lungs were harvested 8 days p.i.

\section{Histological examination}

Samples of the organs mentioned above were fixed in paraformaldehyde-lysine-periodate (PLP) and embedded in paraffin. Serial $4 \mu \mathrm{m}$ thick sections were prepared for hematoxylineosin (HE) staining and immunoperoxidase staining using monoclonal antibodies (McAb) to 
RCMV antigens as described earlier $(37,38)$. Specificity of the $\mathrm{McAb}$ (numbers 8 and 35 ) was described before (7). Monoclonal antibodies ED-1 and W3/13 were used for identification of rat monocytes/macrophages and rat $\mathrm{T}$-cells, respectively $(3,10)$.

For morphometric analyses a reticulin staining was performed and the size of the alveolar wall was measured as described before (38). The relative amount of inflammatory infiltrate in alveolar septa was assessed semi-quantitatively in each section and was expressed in score units: absence of cells was scored as 0 , slight inflammatory infiltrate as 1 , moderate dense infiltrate as 2 , and severe dense inflammatory infiltrate as 3.

\section{Statistical analysis}

For statistics on the in vitro results, the Mann-Whitney test and Fisher"s exact test were applied.

Combined interaction was calculated from the fractionairy effective dose (FED):

$$
\mathrm{FED}=\left(\mathrm{ED}_{\mathrm{A}}{ }^{\mathrm{comb} /} / \mathrm{ED}_{\mathrm{A}}{ }^{\text {alone }}\right)+\left(\mathrm{ED}_{\mathrm{B}}^{\mathrm{comb} /} / \mathrm{ED}_{\mathrm{B}}^{\text {alane }}\right)
$$

$\mathrm{ED}_{\mathrm{A}}{ }^{\mathrm{comb}}$ and $\mathrm{ED}_{\mathrm{A}}{ }^{\text {alone }}$ stand for the minimal effective dose of agent $\mathrm{A}$ when used in combination or alone (41). The in vivo activity of a drug is expressed as the minimal effective dose or the daily dose at which at least $50 \%$ of the animals survived the lethal infection $\left(E_{50}\right)$.

FED values between 0.75 and 1.25 were considered to express an additional effect. FED values below 0.75 were considered to indicate a weak synergistic effect, FED values of 0.5-0.25 indicated a moderate synergistic effect and FED values of 0.25 or below were associated with a strong synergistic effect. For comparison of survival curves, the generalized Wilcoxon test by Gehan was used $(15,17)$. For distribution of discontinue variables by one-way ANOVA the Kruskall-Wallis test was used (43). For Two-tailed differences the Mann-Whitney U-Wilcoxon rank sum $W$ test was used. $P$-Values $<0.05$ were considered statistical significant.

\section{Results}

\section{Activity of DHPG and HIS in vitro}

DHPG inhibited RCMV plaque formation by $50 \%$ at a concentration ( $\mathrm{EC}_{50}$ ) of $25 \mu \mathrm{g} / \mathrm{ml}$. The cell growth inhibitory concentrations (IC so $_{0}$ ) of DHPG in non-infected REF was $1900 \mu \mathrm{g} / \mathrm{ml}$. The selectivity index (ratio of $\mathrm{IC}_{50}$ for cell growth to $\mathrm{EC}_{50}$ for $\mathrm{CMV}$ plaque formation) of DHPG for RCMV was 76.

For HIS the neutralization titre (NTs0, the titre at which serum neutralizes $50 \%$ of the free virus) of the serum pool was 1:640 $\left(1.6 \cdot 10^{-3}\right)$. However, at a HIS concentration as high as $20 \%(\mathrm{w} / \mathrm{v})$ in $\mathrm{BME}$ the growth of REF cells was not inhibited $\left(\mathrm{IC}_{50}>0.2\right)$, resulting in a selectivity index of $>125$. 
Table 1. Effect of treatment on survival of rats after generalized RCMV infection ${ }^{3}$.

\begin{tabular}{|c|c|c|c|c|c|}
\hline \multirow[t]{2}{*}{ Treatment } & \multirow{2}{*}{$\begin{array}{l}\text { Dosage } \\
\text { (mg/kg/day) }\end{array}$} & \multirow{2}{*}{$\begin{array}{l}\text { Nestralization } \\
\text { titre }\end{array}$} & \multicolumn{3}{|c|}{ Generalized infection } \\
\hline & & & Survival & $(\%)$ & $\mathrm{MDD}^{\mathrm{b}}$ \\
\hline \multirow[t]{4}{*}{ DHPG' } & 5 & & $0 / 10$ & $(0)$ & $7.8 \pm 1.3$ \\
\hline & 10 & & $0 / 10$ & (0) & $8.7 \pm 2.2$ \\
\hline & 20 & & $10 / 14^{i}$ & (75) & $14.0 \pm 2.6^{f}$ \\
\hline & 40 & & $7 / 8^{7}$ & $(88)$ & 17.0 \\
\hline \multirow[t]{4}{*}{$\mathrm{HIS}^{\mathrm{d}}$} & & 5 & $0 / 10$ & $(0)$ & $8.1 \pm 1.0$ \\
\hline & & 10 & $2 / 10$ & $(20)$ & $9.3 \pm 2.5$ \\
\hline & & 20 & $7 / 10^{\mathrm{f}}$ & $(70)$ & $15.3 \pm 2.1^{8}$ \\
\hline & & 40 & $10 / 10^{\circ}$ & $(100)$ & - \\
\hline \multirow[t]{5}{*}{$\mathrm{DHPG}+\mathrm{HIS}$} & 2.5 & 2.5 & $1 / 8$ & (13) & $8.3 \pm 1.3$ \\
\hline & 5 & 5 & $7 / 9^{r}$ & $(78)$ & $15.5 \pm 0.7^{7}$ \\
\hline & 10 & 10 & $8 / 9^{r}$ & (89) & 10 \\
\hline & 20 & 20 & ND & & \\
\hline & 40 & 40 & ND & & \\
\hline $\mathrm{PBS}^{\mathrm{c}}$ & & & $0 / 12$ & $(0)$ & $7.6 \pm 0.7$ \\
\hline $\mathrm{CIS}^{\mathrm{e}}$ & & & $0 / 10$ & $(0)$ & $7.9 \pm 1.2$ \\
\hline Non-infected, & & & $5 / 5^{r}$ & (100) & \\
\hline
\end{tabular}

"Groups of $6 \mathrm{BN}$ rats each received 5.0 Gy TBI 24 hours before either intraperitoneal inoculation with $10^{5}$ PFU RCMV. Survival was recorded for 21 days p.i.

${ }^{b}$ Mean day of death ta standard deviation.

- DHPG twice daily for 5 days, started 6 hours p.i. Controls received PBS.

" $\mathrm{H}=\mathrm{IS} \mathrm{I} \mathrm{m} /$ with a neutralization titre of 640 was diluted in $\mathrm{BME}+2 \% \mathrm{NCS}$ and administered in one single dose 6 hours p.i. The corresponding titre after dilution is presented.

- $\mathrm{CIS}$ with a neutralization titre $<10$ and a negative immunofluorescence titre was administered undiluted in one single dose 6 hours p.i.

f $p<0.01$.

\section{Effect of treatment on generalized CMV infection}

\section{Survival}

RCMV-infected irradiated rats died at $7.6 \pm 0.7$ days p.1. As indicated in table 1, DHPG therapy at a dose of $40 \mathrm{mg} / \mathrm{kg} / \mathrm{day}$, started $6 \mathrm{~h}$ p.i. and continued for 5 days with a dose interval of 12 h prevented mortality from RCMV infection in $88 \%$ of the cases (survival: $7 / 8 ; \mathrm{MDD}=17.0$ ). DHPG treatment for 3 days was not effective (survival: $0 / 10$ ). If the onset of treatment was delayed for 3 days p.i., no survival occurred (survival: $0 / 10, \mathrm{MDD}=7.7 \pm 1.3$ days), (data not shown).

For DHPG the $\mathrm{ED}_{50}$ was $20 \mathrm{mg} / \mathrm{kg} /$ day (twice daily for 5 days). In addition, the MDD $(14.0 \pm 2.6)$ was extended significantly by DHPG treatment $(P<0.01)$, as compared to untreated animals. 
The ED 50 of HIS was 40 times the NT 50 . At this dose, the MDD was $15.3 \pm 2.1(P<0.01)$. However, CIS treatment did not affect survival. Analogously to DHPG treatment, HIS had no effect on survival when administration was delayed for 3 days p.i. and no effect on the MDD could be recorded (survival: $0 / 10, \mathrm{MDD}=8.0 \pm 1.2$ days).

The $\mathrm{FED}_{50}$ for the combination of DHPG and HIS was 0.50 , indicating a moderate synergistic effect.

Control rats, which received either TBI or RCMV, all survived (5/5) as did the animals which received. CMV-negative salivary gland homogenate $(5 / 5)$.

\section{Virus titres}

Table 2 shows the effects of DHPG and HIS treatment regimens on the virus titres in several organs at 7 days p.i. After DHPG treatment at dosages of 40 and $20 \mathrm{mg} / \mathrm{kg}$ administered for 5 days, RCMV titres in the liver and lungs were reduced by $3 \log$ values versus untreated controls $(P<0.01)$, but RCMV titres in spleen were not significantly affected. DHPG dosages of $10 \mathrm{mg} / \mathrm{kg} /$ day or less administered for 5 days, did not markedly reduce virus titres in any organ (data not shown).

Likewise, administration of HIS ( $1 \mathrm{ml}$ serum with a NT 50 of 160 ) caused a significant reduction of virus titres in the liver and lungs as compared to untreated controls $(P<0.01)$, but had no effect on virus titres in the spleen. In addition, combined treatment with DHPG and IIIS significantly reduced virus titres in lungs and liver to below detection leve $\|(P<0.01)$, but again RCMV titres in the spleen were not significantly affected.

\section{Effect of DHPG and HIS treatment on RCMV-induced IP}

\section{Virus titres in lungs and spleen}

The effect of DHPG and HIS treatment on virus titres in lungs and spleen of RCMV-infected allogeneic BMT recipient rats was measured using treatment schedules shown to be adequate for treatment of generalized infection, i.e., DHPG $20 \mathrm{mg} / \mathrm{kg}$ twice daily administered for 5 days and one dose HIS with a NT of 160. As shown in table 3, under these conditions treatment with DHPG and HIS resulted in a significant decrease in RCMV titres in lungs, which were reduced from $3.8 \pm 0.3 \log _{10} \mathrm{PFU} / \mathrm{g}$ tissue in untreated rats to $1.3 \pm 0.5$ and $1.7 \pm 0.6 \log _{10}$ PFU/g in the DHPG-and HIS-treated groups, respectively $(P<0.01)$. However, after CIS treatment no effect on virus titres was recorded $\left(3.5 \pm 0.1 \log _{10} \mathrm{PFU} / \mathrm{g}\right)$. In the spleen virus titres decreased only slightly from $4.3 \pm 1.1$ to $3.2 \pm 0.3 \log _{10}$ PFU/g after DHPG treatment. In contrast, HIS treatment resulted in a significant decrease of virus titres in the spleen to $1.6 \pm 0.6 \log _{10}$ PFU/g $(P<0.01)$. Again, no significant reduction of virus titres was noticed after CIS treatment $\left(4.0 \pm 1.0 \log _{10} \mathrm{PFU} / \mathrm{g}\right)$.

After combined treatment with DHPG and HIS, a complete reduction was established of virus titres in the lungs. In addition, RCMV titres in the spleen were decreased to below detection 
Table 2. Effect of combined treatment on organ wirus titres during generalized infection".

\begin{tabular}{|c|c|c|c|}
\hline \multirow[t]{2}{*}{ Therapy } & \multicolumn{3}{|c|}{ Vinus titres" } \\
\hline & Spleen & Liver & Lungs \\
\hline untreated & $6.2 \pm 0.5$ & $5.5 \pm 0.3$ & $5.1 \pm 0.3$ \\
\hline $\mathrm{CHS}^{\mathrm{e}}$ & $5.6 \pm 1.3$ & $5.3 \pm 1.4$ & $4.5 \pm 2.9$ \\
\hline $\mathrm{HIS}^{\mathrm{d}}$ & $5.3 \pm 1.1$ & $<1.3^{\mathrm{f}}$ & $<1.3^{\mathrm{f}}$ \\
\hline $\mathrm{DHPG}^{\mathrm{e}}$ & $4.0 \pm 1.5$ & $2.9=1.2^{r}$ & $2.9 \pm 1.8^{f}$ \\
\hline DHPG+HIS & $4.2 \pm 11.8$ & $<1.3^{\mathrm{f}}$ & $<1.3^{t}$ \\
\hline
\end{tabular}

"Groups of $6 \mathrm{BN}$ rats each received 5.0 Gy TBI 24 hours before intraperitoneal inoculation with $10^{5}$ PFU RCMV. Organis were harvested 8 days post infection.

This table is representative for 2 repetitive experiments.

${ }^{b}$ Log 10 PFU/g tissue.

"Control immune serum (CIS) $1 \mathrm{mll}$ with a neutralization titre $<10$ was administered in one single dose at 6 hours p.i.

d HIS I ml with a neutralization titre of 640 was administered in one single dose at 6 hours p.i.

"DHPG $20 \mathrm{mg} / \mathrm{kg} /$ day twice daily for 5 days, started 6 hours $P<0.01$.

level $(P<0.01)$. Combined DHPG and CIS treatment decreased RCMV titres to $1.4 \pm 0.9$ and $2.4 \pm 0.6 \log _{10} \mathrm{PFU} / \mathrm{g}$ in lung and spleen, respectively $(P<0.01)$.

\section{Pathology}

After allogeneic BMTx and subsequent RCMV infection more than $90 \%$ of the recipients died, at 8-10 days p.i., showing signs of severe dyspnea. Moreover, all rats displayed macroscopic signs of infection in internal organs consistent with symptoms after generalized RCMV infection (40).

At 8 days p.i. RCMV-infected allogeneic BMT recipient rats showed dilatation of alveolar vessels and infiltration of the perivascular area with mononuclear (MN) cells, mainly consisting of W3/13 and ED-1 positive cells. Furthermore, alveolar edema, haemorthages and diffuse infiltration of alveolar stroma with MN cells, in particular ED-1 and W3/13 reactive cells was noticed, accompanied by severe thickening of the alveolar septal wall $(6.0 \pm 1.6$ $\mu \mathrm{m}$ ), (table 4). Treatment with DHPG $20 \mathrm{mg} / \mathrm{kg} /$ day for 5 days significantly reduced the number of infiltrating $\mathrm{MN}$ cells, including ED-1 and W3/13 reactive cells. In addition, the pattern of the infiltrating cells was focal. However, haemorrhagic congestion and vascular dilatation was hardly affected and the alveolar septal wall was still thickened $(4.7 \pm 1.7 \mu \mathrm{m})$. HIS administration in one dose significantly reduced the number of infiltrating $\mathrm{MN}, \mathrm{ED}-1$ and $W 3 / 13$ reactive cells as compared to untreated rats and reduced the thickness of alveolar 
Table 3. Effect of treatment on infectious CMV in allogeneic BMT recipient rats ${ }^{\text {a }}$.

\begin{tabular}{|c|c|c|c|c|c|c|}
\hline \multirow[t]{2}{*}{ Group } & \multirow[t]{2}{*}{ Treatment } & \multirow{2}{*}{$\begin{array}{l}\text { Infection } \\
\left(10^{5} \mathrm{PFU}\right)\end{array}$} & \multirow[t]{2}{*}{ BMTx } & \multirow[t]{2}{*}{ (n) } & \multicolumn{2}{|c|}{ Virus titres } \\
\hline & & & & & Lung & Spleen \\
\hline 1 & none & RCMV & allogeneio & (22) & $3.8 \pm 0.3$ & $4.3 \pm 1.1$ \\
\hline 2 & DHPG & RCMV & allogeneic & (12) & $1.3 \pm 0.5^{f}$ & $3.2 \pm 0.3$ \\
\hline 3 & HIS $^{d}$ & $\mathrm{RCMV}$ & allogeneic & (11) & $1.7 \pm 0.6^{\mathrm{r}}$ & $1.6 \pm 0.6^{\mathrm{f}}$ \\
\hline 4 & $\mathrm{CIS}^{\mathrm{e}}$ & $\mathrm{ROMV}$ & allogeneic & (6) & $3.4 \pm 0.3$ & $4.0 \pm 1.0$ \\
\hline 5 & DHPG+HIS & RCMV & allogeneic & (6) & $<1.25^{\mathrm{f}}$ & $<1.25^{\circ}$ \\
\hline 6 & DHPG+CIS & RCMV & allogeneic & (6) & $1.4 \pm 0.9^{\circ}$ & $2.4=0.6^{f}$ \\
\hline 7 & none & RCMV & syngeneic & (8) & $4.1 \pm 0.2$ & $3.9 \pm 0.2$ \\
\hline 8 & none & none & allogeneic & (8) & N.D. & N.D. \\
\hline
\end{tabular}

${ }^{a}$ Groups of $6 \mathrm{BN}$ rats each received $9.6 \mathrm{~Gy}$ TBI and $5 \cdot 10^{7}$ viable allogeneic and syngeneic bone marrow cells 2 hours before inoculation with $10^{5}$ PFU RCMV i.p. Organs were harvested 8 days. post infection.

This table is composed of 2 repetitive experiments.

${ }^{b}$ Log ${ }_{10}$ PFU/g tissue.

'DHPG $20 \mathrm{mg} / \mathrm{kg} /$ day twice daily fior 5 days, started 6 hours p.o.t.

"HIS I ml with a neutralization titre of 640 was administered in one single dose 6 hours p.i.

C CIS $1 \mathrm{ml}$ with a neutralization titre $<10$ was administered in one single dose at 6 hours $\mathrm{p} . \mathrm{i}$.

$P<0.01$.

septa to $2.9 \pm 0.5 \mu \mathrm{m}$ as compared to untreated, or DHPG-treated or CIS-treated rats $(P<0.01)$. CIS treatment had no effect on the number of alveolar infiltrating $M N, E D-1$ and W3/13-reactive cells and haemorrhages, nor on the thickness of the alveolar septal wall, nor on perivascular infiltration.

Combined treatment with DHPG and HIS reduced the alveolar septal wall within nornal limits $(2.6 \pm 0.2 \mu \mathrm{m})$. In addition, after combined treatment no marked infiltration in the alveolar septal wall, edema and haemorrhages were observed $(\mathrm{P}<0.01)$ and perivascular infiltrates and vascular dilatation were absent. Likewise, combined treatment with DHPG and CIS had similar effects.

Minimal alveolar infiltration and minimal alveolar septal thickening were observed in untreated controls after allogeneic BMTX without RCMV infection $(1.8 \pm 0.2 \mu \mathrm{m})$ and after syngeneic BMTX with subsequent RCMV infection $(2.5 \pm 0.4 \mu \mathrm{m})$.

\section{Discussion}

In the present study, we evaluated the effect of treatment with either DHPG or HIS or the combination of these two agents in two different infection models, one inducing a generalized RCMV infection $(37,38)$ and the other specifically inducing RCMV-induced IP (40), 
Table 4. Effect of treatment on CMV-induced alveolar cell infiltration in allogeneic BMT recipient rats .

\begin{tabular}{|c|c|c|c|c|c|c|c|c|}
\hline Group & Treatment & $\begin{array}{l}\text { Infection } \\
\left(10^{5} \mathrm{PFO}\right)\end{array}$ & BMTX & (n) & $\begin{array}{l}\text { Alveolar } \\
\text { septal } \\
\text { thickness } \\
(\mu m)^{b}\end{array}$ & $\begin{array}{l}\text { MN } \\
\text { infil- } \\
\text { iration } \\
\text { score }\end{array}$ & $\begin{array}{l}\text { ED-1 } \\
\text { score }^{\mathrm{c}}\end{array}$ & $\begin{array}{l}\text { W3/13 } \\
\text { score }^{c}\end{array}$ \\
\hline 1 & nones & $\mathrm{RCMV}$ & allogeneic & $(22)$ & $6.0 \pm 1.6$ & $2(3)$ & $2(2)$ & $2(3)$ \\
\hline 2 & $\mathrm{DHPG}^{\mathrm{d}}$ & $\mathrm{RCMV}$ & allogeneic & (12) & $4.7 \pm 1.7$ & 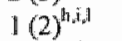 & $1(2)^{\mathrm{h}, \mathrm{i}}$ & $1(3)^{h, i}$ \\
\hline 3 & $\mathrm{HIS}^{\mathrm{e}}$ & RCMY & allogeneic & (11) & $2.9 \pm 0.5^{8}$ & $\|(4)^{h, i_{j}, n t h}$ & $1(4)^{h, y i n g}$ & $\|(3)^{\mathrm{h}, \mathrm{i}, \mathrm{m}}$ \\
\hline 4 & $\mathrm{CIS}^{\mathrm{f}}$ & RCMV & allogeneic & (6) & $5.8 \pm 1.1$ & $3(1)^{\mathrm{mn}}$ & $2(3)^{\mathrm{m}}$ & $2(1)^{\mathrm{m}}$ \\
\hline 5 & $\mathrm{DHPG}+\mathrm{HIS}$ & RCMV & allogeneic & (6) & $2.6 \pm 0.2^{8}$ & $0(1)^{\text {hl, }, i}$ & $1(2)^{\mathrm{h}, \mathrm{i}}$ & $\mathbb{\|}(1)^{\mathrm{hi} i}$ \\
\hline 6 & DHPG+CIS & RCMY & allogeneic & (6) & $2.6 \pm 0.4^{8}$ & $0(1)^{h, i}$ & $1(1)^{\mathrm{h}, \mathrm{i}}$ & $2(2)$ \\
\hline 7 & none & RCMV & syngeneic & (8) & $2.5 \pm 0.4^{g}$ & $1(0)^{h, i}$ & $0.5(1)^{h, i}$ & $1(1)^{h, i}$ \\
\hline 8 & none & none & allogeneic & (8) & $1.8 \pm 0.2^{8}$ & $\|(2)^{h, i}$ & $1(1)^{h, j}$ & $1(1)^{h, i}$ \\
\hline
\end{tabular}

"Groups of $6 \mathrm{BN}$ rats each received $9.6 \mathrm{~Gy}$ TBI and $5 \cdot 10^{7}$ viable allogeneic and syngeneic bone marrow cells 2 hours before inoculation with $10^{5}$ PFU RCMV i.p. Organs were harvested 8 days post infection.

This table is representative for 2 repeatative experiments.

${ }^{6}$ The alveolar septa from each rat were measured 10 times by 2 independent observers. Each number represents the mean and standard deviation for these measurements in each group of rats.

${ }^{\circ}$ The presence of infiltitating mononuclear cells was scored on a scale from 0 (absent) to 3 (maximum); mean (variance).

th DHPG $20 \mathrm{mg} / \mathrm{kg} /$ day twice daily for 5 days, started 6 hours p.i.

"HIS $1 \mathrm{ml}$ with a neutralization titre of 640 was administered in one single dose 6 thours p.i.

${ }^{8} \mathrm{CIS} 1 \mathrm{ml}$ with a neutralization titre $<10$ was administered in one single dose at 6 hours p.i.

Differences by $T$-test versus group $1, P<0.05$.

Kruskal-Wallis two way ANOVA: "versus group 1, $P<0.05^{j}$ group 4 versus 2 and 3 .

Significant differences by Manm-Whitney U-Wilcoxon Rank W Sum Test: ' group I versus $2,3,4,5,6,7,8$. mgroup 3 versus 4.

The specific action of DHPG for rat and human CMV in vitro, as expressed by the selectivity index, is comparable ( 80 and 1.00 , respectively), $(1,28,38)$. HIS also shows a strong sellective neutralizing effect on RCMV infection in vitro, since the selectivity index of HIS for RCMV was about $125(37)$.

In the generalized infection model the ED $\mathrm{D}_{50}$ of DHPG was $20 \mathrm{mg} / \mathrm{kg} /$ day twice daily for 5 days. At that dose $75 \%$ of the animals survived infection. To be effective treatment thad to be started within $48 \mathrm{~h}$ p.i. The therapeutic range of DHPG in generalized RCMV infection was at least 15 , as calculated from the $\mathrm{ED}_{50}$ and the toxic dose (in earlier studies toxicity was not observed at dosages up to $300 \mathrm{mg} / \mathrm{kg} /$ day (38). At a dose of $20 \mathrm{mg} / \mathrm{kg} /$ day DHPG treatment significantly reduced virus titres in liver and lungs, but not in spleen. In man, therapeutic activity of DHPG is recognized at $10 \mathrm{mg} / \mathrm{kg} /$ day after generalized CMV infections $(8,16)$. At that dose DHPG treatment reduces mortality from CMV infection $(11,21,23,27)$. So, DHPG seems to be effective in rats at the same dosage as described for man.

HIS treatment significantly reduced both mortality and virus titres in lungs and the liver, but not in the spleen, of CMV-infected rats. Although the mechanism is not clear, HIS treatment 
was effective only early in the course of infection, emphasizing the importance of timing for the success of therapy. Furthermore, as we pointed out earlier, the success of antibody therapy also largely depends on the degree of immunosupression of the host (37). These aspects may possibly contribute to therapy failure of HIS treatment for generalized CMV infections in man, in whom the onset of treatment is generally late (35). Another aspect of the limited. success of HIS treatment, as applied in man, is due to the HIS preparations used. HIS is generally produced from CMV-seropositive donors with high immunofluorescence and neutralization titres, but the qualification of the preparations is not well established and depends on the donor population used (35). Furthermore, the effect of HiS treatment may largely depend on the kind of immunosuppression in the host system. The beneficial effect of HIS treatment is most promising in bone marrow transplant and kidney transplant recipients where the viremic phase seems to be significantly shortened and the rate of interstitial pneumonitis is diminished (35).

Using combined treatment of DHPG and HIS in generalized RCMV infection, the dose of DHPG could be reduced 4-fold to obtain $78 \%$ survival. Also the dosage of HIS could be reduced 4 times, resulting in a $\mathrm{FED}_{50}$ of 0.5 , indicating a moderate synergistic effect of these two agents.

IP is one of the most life-threatening symptoms of CMV infection in man and occurs predominantly in allogeneic BMT recipients. To study the effect of treatment on CMV-induced IP we have chosen a model in which the animals received a BMTX across a large class I major histocompatibility complex barrier (Lewis to BN rats), TBI and RCMV infection, all described to be risk factors for development of IP (22). Severe IP accompanied by high virus titres in internal organs, including the lungs was recorded at eight to ten days p.i. Although DHPG treatment induced a significant decrease in RCMV titres in the lungs, the effect of DHPG on the immunopathological changes by RCMV-induced IP was relatively low. DHPG had only a minor but not significant effect on both mononuclear cell infiltration and thickness of the alveolar septa and no effect on vascular dilatation and alveolar edema and haemorrhages. These findings are consistent with the reports about the limited effect of DHPG treatment on human CMV-induced IP in allogeneic BMT recipient patients $(9,14,32)$. In our view, the failure of response to antiviral treatment emphasizes the role of immunopathologic responses in the pathogenesis of CMV-induced IP (18,30).

In contrast to the poor response on DHPG therapy, the effect of HIS administration on CMV-induced IP seemed to be 2-fold: HIS treatment led to a significant decrease of RCMV titres in the spleen and lungs. This phenomenon could be explained by the fact that the presence of specific antibodies in the blood may inhibit the spread of virus infection in the host, resulting in a decreased virus titre in internal organs. We hypothesize that viral spread may be inhibited by antibody treatment. In addition to its antiviral effect, HIS also prevented RCMV-induced IP, as marked by a significant decrease in infiltrating mononuclear cells, being predominantly ED-1 and W3/13 reactive cells, a reduction in vascular dilatation, a reduction in thickness of the alveolar septal wall and alveolar edema and haemorrhages. CIS had no antiviral effect, nor any effect on $\mathrm{CMV}$-induced histopathologic changes in the lungs, indicating that the antiviral action of HLS is very specific. Likewise, in man many clinical reports describe a 
beneficial effect of HIS on the immunopathologic response to CMV infection in the lungs and a decrease of mortality in BMT recipients, but HIS induces only a minor decrease in infectious virus shedding (46).

Combined treatment of DHPG and HIS resulted in a dramatic decrease in RCMV titres in lungs and in spleen, again indicating a strong inhibitory effect on multiplication of infectious virus. As compared to HIS alone, no significant differences were noticed between the inflammatory response in the lungs and vascular dilatation after combined DHPG and HIS therapy, probably because of the strong beneficial effect of antibodies on the immunopathological response in the lungs. A particular observation was that the combination of DHPG and CIS was as effective as the combination of DHPG and HIS and was significantly more effective then DHPG alone in decreasing histopathologic changes in the lungs. This led to the hypotheses that the reduction of immunopathologic changes by HIS is not specific, but that reduction in virus titres by either DHPG or antibodies are a prerequisite for the immune modulating effect of non specific sierum antibodies. In man, various reports indicate the improved therapeutic response on CMV-induced $\mathrm{IP}^{\mathrm{P}}$ after combined treatment with HIS and DHPG in allogeneic BMT recipients $(13,24,30,33)$. Generally, the regulation of the immune system can be manipulated by intravenous administered immunoglobulin in several ways: Antigen-antibody complexes can bind the Fc-receptor for IgG on phagocytic, B, and T-cells, In addition, the idiotype antibodies can be recognized by antiidiotype antibodies, which can neutralize auto antibodies and bind and down regulate B-cell receptors for auto antibodies. Of greater importance, T-cells may recognize antiidiotype antibodies or idiotype-antiidiotype complexes, to bind and subsequently suppress certain T-cells by lymphokine induction (12). This possibility may be supported by the finding that in the rat modell lymphokines also affect the course of CMV infection under immunocompromised conditions $(19,20)$, but more research on the pathogenesis of IP and the action of immunoglobulins under these conditions is necessary to study the mechanism by which IP is prevented by CIS.

In conclusion, combined treatment of DHPG and HIS early in generalized infection had a moderate synergistic effect on survival and effectively reduced infectious RCMV titres in lungs and the liver, but not in the spleen. We hypothesize that viral spread may be inhibited by antibody treatment. In addition, combined treatment has a remarkable therapeutic effect on CMV-induced IP after allogenic BMTX, as reflected by both local virus titres as well as the immunopathologic response in the lungs.

\section{References}

1. Balfour, H. H., Jr. 1990. Management of cytomegalovirus disease with antiviral drugs. Rev. Infect. Dis. 12 (Suppl. 7):\$849-S860.

2. Bos, G. M., O. D. Majoor, C. A. Bruggeman, G. Grauls, M. J. wan-de-Gaar, and P. J. van-Breda-Wriesman. 1989. Rat cytomegalovirus can be transferred by bone marrow cells but does not affect the course of acute graft-versus-host disease. Transplant. Proc. 21 (Pt 3):3050-3052. 
3. Brown, W. R. A., A. N. Barclay, C. A. Sunderland, and A. F. Williams. 1981. Identification of a glycophorin-like molecule at the celll-surface of rat thymocytes. Nature. 289:456-460.

4. Bruggeman, C. A., W. M. Debie, G. Grauls, G. Majoor, and C. P. wan-Boven. 1983. Infection of laboratory rats with a new cytomegalo-like wirus. Arch. Virol. 76:189-199.

5. Bruggeman, C. A. H. Meijer, F. Bosman, and C. P. van-Boven. 1985. Biology of rat cytonegalovirus infection. Intenvirology. 24:1-9.

6. Bruggeman, C. A., H. Meijer, P. H. J. Dormans, W. M. H. Debie, G. E. L. M. Grauls, and C. B. A. van Boven. 1982. Isolation of a cytomegalowirus-like agent from wild rats. Arch. Wirol 73:231-241.

7. Bruning, J. H., W. H. Debie, P. H. Dormans, H. Meijer, and C. A. Bruggenan. 1987. The development and characterization of monoclonal antibodies against rat cytomegalowirus induced antigens. Arch. Virol. 94:55-70.

8. Collaborative DHPG Treatment Study Group. 1986. Treatment of serious cytomegalovirus infections with 9-(1,3-dihydroxy-2-propoxymethyl)guanine in patients with AIDS and other immunodeficiencies. N. Engl. J. Med. 314:801-805.

9. Crumpacker, C., S. Marlowe, J. L. Zhang, S. Abrams, P. Watkins, and Ganciclowir Bone Marrow Treatment Group. 1988. Treatment of cytomegalovinus pneumonia. Rev. Infect. Dis. :S538-S546.

10. Dijkstra, C. D., E. A. Döpp, P. Joling, and G. Kraal. 1985. The heterogeneity of mononuclear phagocytes in lymphoid organs: distinct macrophage subpopulations in the rat recognized by monoclonal antibodies ED1,ED2 and ED3. Immmology. 54:589-599.

11. Drew, W. L. 1991. Clinical use of ganciclovir for cytomegalowirus infection and the development of drug resistance. J. Acquir. Immune. Defic. Syndr. 4 (Suppl. 1):S42-S46.

12. Dwyer, J. M. 1992 . Manipulating the immune system with immune globulin. N. Engl. J. Med. 326:107-116.

13. Emanuel, D., 1. Cunningham, K. Jules-Elysee, J. A. Brochstein, N. A. Keman, J. Laver, D. Stover, D. A. White, A. Fels, B. Polsky, H. Castro-Malaspina, J. R. Peppard, P. Bartus, U. Hammerling, and $\mathbb{R}_{.}$J. O'Reilly. 1988. Cytomegalovirus pneumonia after bone marrow transplantation successfully treated with the combination of ganciclovir and high-dose intravenous immume globulin. Ann. Intern. Med. 109:777-782.

14. Erice, A., M. C. Jordan, B. A. Chace, C. Fletcher, B. J. Chinnock, and H. H. Balfour Jr. 1987. Ganciclovir treatment of cytomegalovirus disease in transplant recipients and other immunocompromised hosts. Jama, 257:3082-3087.

15. Gehan, E. 1956. Generalized Wilcoxon test for comparing arbitrarily single sensored samples. Biometrica 52:203-224.

16. Goodrich, J. M., M. Mori, C. A. Gleaves, C. Du-Mond, M. Cays, D. I. Ebeling, W. C. Buhles, B. DeArmond, and J. D. Meyers. 1991. Early treatment with ganciclovir to prevent cytomegalovirus disease after allogeneic bone marrow transplantation. N. Engl. J. Med. 325:1601-1607.

17. Gross, A. J, and V. A. Clarck. 1975. Survival distributions: reliability applications in the biomedical sciences. John Wiley and Sons, Inc., New York.

18. Grundy, J. E., J. D. Shanley, and P. D. Griffiths. 1987. Is cytomegalovirus interstitial pneumonitis in transplant recipients an immunopathological condition? Lancet. 2:996-999.

19. Haagmans, B. L., F. S. Stals, P. H. varn-der-Meide, C. A. Bruggeman, M. C. Horzinek, and V. E. Schijns. 1994. "Tumor necrosis factor ialpha promotes replication and pathogenicity of rat cytomegalowirus. $J$. Virol. 68:2297-2304.

20. Haagmans, B. L., P. H. van-der-Meide, F. S. Stals, A. J. van-den-Eertwegh, E. Claassen, C. A. Bruggeman, M. C. Horzinek, and V. E. Schijns. 1994. Suppression of rat cytomegalovirus replication by antibodies against gamma interferon. J. Viral. 68:2305-2312. 
21. Hirsch, M. S. 1992. The treatment of eytomegallovirus in AIDS-more than meets the eye. N. Engl. J. Med. 326:264-266.

22. $\mathrm{Ho}_{4}$ M. 1991. Cytomegalowirus. Biology and Infeetion. Plenum Medical Book Company, New York. $440 \mathrm{pp}$.

23. Laskin, O. L., D. M. Cederberg, J. Mills, L. J. Eron, D. Mildvan, and S. A. Spector. 1987, Ganciclovir for the treatment and suppression of serious infections caused by cytomegalovirus. Am. $J . \mathrm{Med}$ $83 \div 201-207$.

24. Ljungman, P., D. Engelhard, H. Link, P. Biron, L. Brandt, S. Brunet, C. Cordonnier, L. Debusscher, A. de-Laurenzi, H. J. Kolb, C. Messina, A. C. Newland, H. G. Prentice, C. Richard, T. Ruutu, H. Tilg, and L. Werdonck. 1992. Treatment of interstitial pneumonitis due to cytomegalovirus with ganciclovir and intravenous immune globulin: experience of European Bone Marrow Transplant Group. Clin. Infect. Dis. 14:831-835.

25. Meijer, $H_{n}$ P. H. Dormans, J. L. Geelen, and C. P. van-Boven. 1984. Rat cytomegalovirus: studies on the viral genome and the proteins of wirions and nucleocapsids. J. Gen. Virol. 65 (Pt 4):681-695.

26. Meijer, H., J. C. Dreesen, and C. P. Van-Boven. 1986. Molecular cloning and restriction endonuclease mapping of the rat cytomegallovirus genome. $J$. Gen. Virol. 67 (Pt 7):1327-1342.

27. Ocular Complications of AIDS research Group, AlDS Clinical Trials Group. 1992. Mortality in patients with the acquired immunodeficlency syndrome treated with either foscarnet or ganciclovir for eytomegalovirus retinitis. N. Engl. J. Med. 326:213-220.

28. Plotkin, S. A., W. L. Drew, D. Felsenstein, and M. S. Hirsch. 1985. Sensitivity of clinical isolates of human cytomegalovirus to 9-(1,3-dihydroxy-2-propoxymethyl)guanine. J. Infect. Dis. 152:833-834.

29. Plummer, $\mathrm{G}_{\mathrm{n}}$, and $\mathrm{M}$. Benyesh-Melnick. 1964. A plaque reduction neutralization test for human cytomegalovirus. Proc. Soc: Exp. Biol. Med. 117:145-150.

30. Reed, E. C., R. A. Bowden, P. S. Dandliker, K. E. Lilleby, and J. D. Meyers. 1988 . Treatment of cytomegalowirus pneumonia with ganciclovir and intravenous cytomegalowirus immunoglobulin in patients with bone marrow transplants. Anm. Intern. Med. 109:783-788.

31. Rubin, R. H. 1991. Preemptive therapy in immunocompromised hosts [editorial; comment]. N. Engl. J. Med. 324:1057-1059.

32. Schmidt, G. M., D. A. Horak, J. C. Niland, S. R. Duncan, S. J. Forman, J. A. Zaia, and City of Hope-Stanford-Syntex CMV Study Group. 1991. A randomized, controlled trial of prophylactic ganciclovir for cytomegalovirus pulmonary infection in recipients of allogeneic bone marrow transplants. N. Engl. J. Med. 324:1005-1011.

33. Schmidt, G. M., A. Kovacs, J. A. Zaia, D. A. Horak, K. G. Blume, A. P. Nademanee, M. R. O'Donnell, D. S. Snydler, and S. J. Forman. 1988. Ganciclovir/immunoglobulin combination therapy for the treatment of human cytomegalovirus-associated interstitial pneumonia in bone marrow allograft recipients. Transplantation. 46:905-907.

34. Shepp, D. H., P. S. Dandliker, P. de-Miranda, T. C. Burnette, D. M. Cederberg, L. E. Kirk, and J. D. Meyers. 1985. Activity of 9-[2-hydroxy-1-(hydroxymethyl)ethoxymethyl]guanine in the treatment of cytomegalovirus pneumonia. Ann. Intern. Med. 103:368-373.

35. Snydman, D. R. 1990. Cytomegalovirus immunoglobulins in the prevention and treatment of cytomegalovirus disease. Rev. Infect. Dis. 12 (Suppl. 7):S839-\$848.

36. Snydman, D. R., B. G. Werner, B. Heinze-Lacey, V. P. Berardi, N. L. Tilney, R. L. Kirkman, E. L. Milford, S. I. Cho, H. L. Bush Jr., A. S. Levey, T. B. Strom, C. B. Carpenter, R. H. Levey, W. E. Harmon, C. E. Zimmerman, M. E. Shapiro, T. Steinman, F. LoGerfo, B. Idelson, G. P. J. Schroter, M. J. Levin, J. Mclver, J. Leszczynski, and G. F. Grady. 1987. Use of cytomegalovirus immune globulin to prevent cytomegalowirus disease in renal-transplant recipients. N. Engl. J. Med. 317:10491054. 
37. Stals, F. S., F. Bosman, C. P. van-Bowen, and C. A. Bruggeman. 1990. An animal modell for therapeutic interwention studies of CMV infection in the immunocompromised host. And Wow. $114: 91-107$.

38. Stals, F. S., E. de-Clercq, and C. A. Bruggenan, 1991. Comparative activity of (S)-1-(3-Indroxy-2phosphonylmethoxypropyl)cytosine and 9-(1,3-dilhyotroxy-2-propoxymethyl)guanine against rat cytomegallovirus infection in vitro and in wivo. Amtimicrob. Agents. Chemother. $35: 2262-2266$.

39. Stals, F. S., A. E. J. M. wan-den-Bogaard, and C. A. Bruggeman. 1990. Selective bovel decontami. nation and the incidence of bacteraemia in irradiated and cytomegalovirus infected trats. Mhotoech Ther, $20: 153-156$.

40. Stals, F. S., A. Zeytinog》u, M. Havenith, E. de-Clercq, and C. A. Bruggeman. 1993. Rat cylomegalovirus -induced pneumonitis after allogeneic bone marrow tiansplantation: effective treatment with (S)-1-(3-hydroxy-2-phosphonyl-methoxypropyl)cytosine. Antimicrob. Agents. Chemother. $37: 218$ 223.

41. Sühnel, J. 1990. Evaluathon of synergism or antagonism for the combined action of antivital agents. Antiviral. Res. 13:23-39.

42. Vancutsem, P. M., J, G. Babish, and W.S. Schwark. 1990, The fluoroquinolone antimicrobials: structure, antimicrobial activity, pharmacokinetics, climical use in domestic animals and toxicity. Cornell. Vet 80:173-186.

43. Wallis, W. A., and H. V. Roberts. 1956. Statistics: A new approach. The Free Press, New York. 464 $\mathrm{PP}$.

44. Wiley, C. A., and J. A. Nelson. 1988. Role of human immunodeficiency virus and cytomegalowirus in AIDS encephalitis. Am. I. Pathol. 133:73-81.

45. Winston, D. J., W. G. Ho, C. L. Howell, M. J. Miller, R. Mickey, W. J. Martin, C. H. Lin, and R. P. Gale. 1980. Cytomegalovirus irfections associated with leukocyte transfiusions. Ann. Mrerr. Mad. 93:671-675.

46. Winston, D. J., W. G. Ho, C. H. Lin, K. Bartoni, M. D. Budinger, R. P. Gale, and R. E. Champlin. 1987. Intravenous immume globulin for prevention of cytomegalovirus infection and interstitial pneumonia after bone marrow transplantation. Ann. Intern. Med. 106:12-18. 


\section{6}

\section{Cytomegalovirus induces interstitial lung disease in allogeneic bone marrow transplant recipient rats independent of acute graft versus host response}

\section{Summary}

Interstitial lung disease (ILD) after allogeneic bone marrow transplantation (BMTx) is an important clinical problem in terms of diagnosis, therapy and pathogenesis. Graft versus Host Disease (GvHD) and cytomegalovirus (CMV) infection seem to be major risk factors for $I L D$, but their role in the pathogenesis is not well established. We previously reported CMV-induced ILD in allogeneic bone marrow transplant (BMT) recipient rats, which was prevented by antiviral drug treatment. In this chapter we describe the pathology of ILD in allogeneic BMT recipient rats and the relation of LLD with CMV infection and GVHD.

Brown Norway (BN) rats received an allogeneic (Lewis) BMTx and rat CMV (RCMV) infection, after an allogeneic (Lewis) lung transplantation and immunosuppression. $\mathrm{CMV}$ infection was recorded by the amount of infectious virus and viral antigens in the lung. ILD was monitored by the presence of diffuse histopathological changes in the alveolar septal wall. GvHD was scored by the relative splenic weights and the presence of perivascular infiltrates in the lung.

Cells expressing CMV antigens were more numerous in the alveolar septa of the allogeneic recipient lungs than in the syngeneic donor lungs $(P<0.05)$. The high virall load in the recipient lung of allogeneic BMT recipient rats was accompanied by diffuse ILD, marked by extensive microvascular damage and congestion of the alveolar septa. ILD was neither observed in the syngeneic donor lung nor in both lungs of mock-infected animals. GvHD was not observed in both RCMV-infected and mock-infected animals.

Our results indicate that CMV induces microvascular damage resulting in ILD. This process is independent of GwHD. 


\section{Introduction}

Allogeneic bone marrow transplantation (BMTX) is the ultimate method of treatment to maintain life in selected groups of patients with leucocyte cancer (9). Although the outcome of allogeneic BMTX is impaired by many factors, the high rate of cytomegalovirus (CMV) infections (50-60\%) particularly is associated with severe clinical disease (14, 23). Interstitial lung disease (ILD) is the most serious complication of CMV infection with a high mortality rate among these patients $(14,36)$.

Besides CMV the occurrence of graft versus host disease (GvHD) is another major risk factor for ILD $(20,26)$. The association between GVHD, CMV infection and ILD, however, is poorly understood. On the one hand there is ewidence supporting that CMV-induced ILD is a direct virus mediated effect, on the other hand it is suggested to be an immunopathological process (13).

The association between CMV infection and GvHD in the pathogenesis of ILD was studied in an allogeneic BMTX model. A single lung allograft, syngeneic to the reconstituted bone marrow, was transplanted into the recipient rats. The severity of ILD was assessed in the bone marrow transplant (BMT) recipient animals by monitoring histopathologic changes in the alveolar septa and alveolar spaces of both lungs. CMV infection was measured regarding presence of infectious virus as well as the presence of CMV antigens in lung tissue. GivHD was determined by measuring the relative splenic weights and cell infiltration in the perivascular and peribronchial regions of the lungs.

\section{Materials and methods}

\section{Animal preparation}

Eight-week-old inbred male Brown Norway (BN) rats, which were specified as pathogen-free (SPF), were used as recipients of a BMT at a total body weight between 160 to $180 \mathrm{~g}$. Allogeneic bone marrow cells were larvested from adult SPF Lewis (Le) donor rats. Donor animals and recipients were CMV seronegative at the start of the experiment, as determined by an enzyme immunoassay according to the method of Enguall et al. (11). All animal experiments were approved by the Uniwersity Ethical Committee for animal studies.

To prevent bacterial infections rats received enrofloxacin at $2 \mathrm{mg} / \mathrm{kg} / \mathrm{day}$ (a fluoroquinolone) in their drinking water (Bayer, Mijdrecht, the Netherlands), starting 5 days before the experiment, as described previously $(31,32)$. In addition, the animals were kept in sterile cages and received sterile food.

\section{Immunosuppression, RCMV infection and transplantation}

For immunosuppression, the rats received 9.6 Gray (Gy) total body X-irradiation (TBI) as described previously (32). Rat CMV (RCMV) infection was achieved by intraperitoneal (i.p.) 
inoculation of rats with $10^{5}$ plaque forming units (PFU) of the virus as described $(7,32)$. The RCMV stock was obtained from a pool of salivary glands, harvested from infected laboratory rats (6). A quantitative assay was performed for RCMV infectivity in spleen and lungs, as described previously (6). The amount of virus was expressed as the logarithm of PFU per gram of tissue. Mock-infected animals received an amount of an appropriate dilution of non-infected salivary gland supernatants.

The preservation technique of the left lateral donor lung and orthotopic lung transplantation (Tx) were performed as described previous ly $(18,22)$. After operation and extubation, animals were placed in a provisional hyperbaric oxygen chamber until fully awake. Thereafter, they were returned to the cages, where they had free access to food and water.

Syngeneic and allogeneic bone marrow cells were obtained from donors as described previously (3). Briefly, tibia and femur were removed from sacrificed donor rats and the marrow cavity of these bones were perfused with Dulbecco's sterile salt balanced solution. Their contents were then passed through a nylon gauze with $200 \mu \mathrm{m}$ mesh. Each rat received $5 \cdot 10^{7}$ freshly harvested viable bone marrow cells intravenously (i.w.).

Allogeneic lymphocyte transfer was performed by i.v. administration of $2.5 \cdot 10^{8}$ fresh and viable lymphocytes. The lymphocytes were harvested from mesenterial, para-aortal and submandibular lymph nodes, passed through a nylon gauze, washed in Eagle's basic medium with $2 \%$ new-born calf serum and resuspended to a tinal concentration of $2.5 \cdot 10^{8}$ cells/ml.

\section{Experimental design}

Figure 1 schematically represents the experimental procedure. On day -1 all rats received the left lung allograft. On day 0 , the animals were immunocompromised by TBI, followed by inoculation with $\mathrm{RCMV}$.. Six hours after TBI, the animals received a BMTX. The experimental groups are listed in table 1.

Animals were checked daily for physical signs of disease. Signs of generalized infection were considered to be ocular discharges, ruffled hair, impaired reactivity to stimuli and a hanch back as described (30). Signs of pulmonary CMV infection were considered to be tachypnoea and dyspnoea. When RCMV-infected rats showed two or more of these physical signs they were sacrificed immediately. Lungs and spleen were removed and processed for histological examination (frozen and paraffin sections) and virus plaque assays, as described previously (30). Total body weights, lung and splenic weights were recorded. Mock-infected rats were sacrificed at the same time as RCMV-infected animals.

RCMV infection was defined by the presence of infectious virus, as indicated by a plaque assay of representative samples from lungs and spleen and by the presence of viral antigens in tissue sections of lungs and spleen, as determined immunohistochemically.

Interstitial lung disease (ILD) was histologically defined as:

a) edema of the alveolar septa, swelling of the endothelial cells, adherence of monocytic cells to the endothelial cells and extravasation of erythrocytes (24), and

b) infiltration of the alveolar septa with monocytic cells $(12,15,24,26,32)$. 


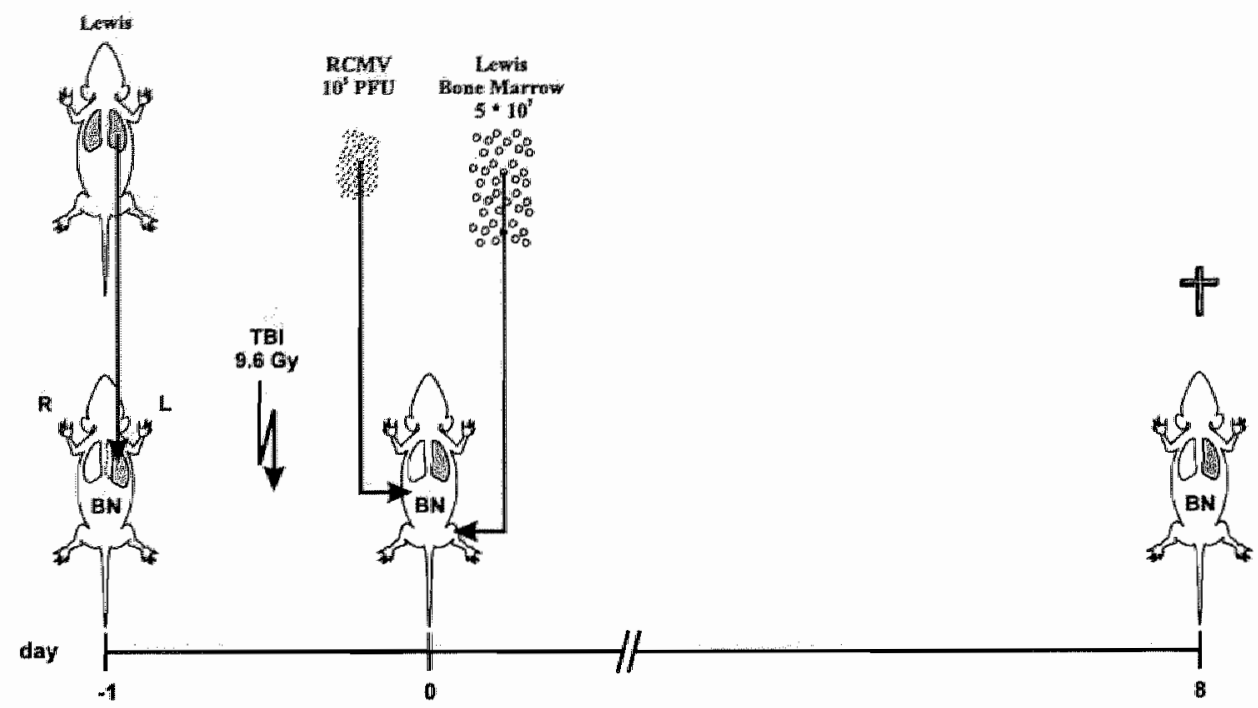

Figure 1. A schernatic representation of the experimental design. A single left donor lung was obtained from a Lewis rat and transplanted into a BN recipient rat of group 1 at one day before BMTX. At the day of BMTX animals received 9.6 Gy TBI for immunosuppression. RCMV infection was established by inoculation of $10^{5}$ PFU RCMV i.p. Four hours after TBI animals received $5 \cdot 10^{7}$ freshly harvested Lewis-derived bone marrow cells. $2.5 \cdot 10^{8}$ Lewis.derived lymphocytes were transferred at 5 days after BMTX. Animals were evaluated for CMV infection, GvHD and ILD at 8 days after BMTx.

GVHID was defined by an increase in relative spleen and by infiltration of mononuclear cells in the peribronchial and perivascular region of the lungs $(27,28,37)$.

\section{Histopathology and immunohistochemistry}

Samples of the spleen and lungs were fixed in paraformaldehyde-lysine-periodate (PLP) and embedded in paraffin. Serial $4 \mu \mathrm{m}$ thick sections were stained with haematoxylin-eosin (HE), van Gieson and immunoperoxidase as described below.

The inflammatory infiltrete in alveolar septa and alveolar spaces was assessed semi-quantitatively in each section. Therefore, two independent observers performed scores, while blinded for the origin of the sections. Differences in scores were subjected to a third independent observer. Absence of inflammatory cells was scored as 0 , slight inflammatory infiltrate as 1, moderate dense infiltrate as 2 , and dense inflammatory infiltrate as 3.

For immunohistochemical staining the sections were routinely handled as described earlier (30). Briefly, after deparaffinization, sections were blocked for their endogenous peroxidase activity by incubation in methanol, containing $0.6 \% \mathrm{H}_{2} \mathrm{O}_{2}$ and preincubated at room temperature with $10 \%$ normal rabbit serum. After several washings the sections were incubated with 
Table 1. Experimental groups.

\begin{tabular}{llllll}
\hline Group & $\begin{array}{l}\text { Lung } T x^{2} \\
\text { donor } \rightarrow \text { recipient }\end{array}$ & $\begin{array}{l}\text { BMTx }^{\mathrm{b}} \\
\text { donor } \rightarrow \text { recipient }\end{array}$ & RCMN infection & $\begin{array}{l}\text { Lymphocyte } \\
\text { transfer }\end{array}$ & $(\mathrm{n})$ \\
\hline 1 & $\mathrm{Le} \rightarrow \mathrm{BN}$ & $\mathrm{Le} \rightarrow \mathrm{BN}$ & $10^{5} \mathrm{PFU}$ & - & $(17)$ \\
2 & $\mathrm{Le} \rightarrow \mathrm{BN}$ & $\mathrm{Le} \rightarrow \mathrm{BN}$ & - & - & $(10)$ \\
3 & $\mathrm{Le} \rightarrow \mathrm{BN}$ & $\mathrm{Le} \rightarrow \mathrm{BN}$ & $10^{5} \mathrm{PFU}$ & $2.5 \cdot 10^{8}$ & $(5)$ \\
4 & $\mathrm{Le} \rightarrow \mathrm{BN}$ & $\mathrm{Le} \rightarrow \mathrm{BN}$ & - & $2.5 \cdot 10^{8}$ & $(5)$ \\
5 & $\mathrm{BN} \rightarrow \mathrm{BN}$ & $\mathrm{Le} \rightarrow \mathrm{BN}$ & $10^{5} \mathrm{PFU}$ & $2.5 \cdot 10^{8}$ & $(5)$ \\
6 & $\mathrm{BN} \rightarrow \mathrm{BN}$ & $\mathrm{Le} \rightarrow \mathrm{BN}$ & - & $2.5 \cdot 10^{8}$ & $(5)$ \\
7 & $\mathrm{Le} \rightarrow \mathrm{BN}$ & $\mathrm{BN} \rightarrow \mathrm{BN}$ & $10^{5} \mathrm{PFU}$ & - & $(10)$ \\
8 & $\mathrm{Le} \rightarrow \mathrm{BN}$ & $\mathrm{BN} \rightarrow \mathrm{BN}$ & - & - & $(7)$ \\
9 & $\mathrm{BN} \rightarrow \mathrm{BN}$ & $\mathrm{BN} \rightarrow \mathrm{BN}$ & - & - & $(5)$ \\
\hline
\end{tabular}

${ }^{a}$ Rats received a left lung transplant by the left lateral lung transplant technique one day before BMTX.

${ }^{b}$ Additionally, animals received 9.6 Gy TBI and $5 \cdot 10^{7}$ viable bone marrow cells i.w.

E $10^{5}$ PFU CMV was administered i.p.

d Lymphocyte transfer was performed by $2.5 \cdot 10^{\text {s }}$ Le-derived viable lymphocytes.

mouse monoclonal antibodies for $1 \mathrm{~h}$. in moist air. For RCMV-antigen detection in tissue samples, a mixture of two monoclonal antibodies was used. One of these monoclonal antibodies, McAb 35, is directed against the $29 \mathrm{kDa}$ late structural protein of RCMV and gives rise to specific diffuse non-granular staining in the cytoplasm of RCMV-infected cells, as described previously (8). The other monoclonal antibody, $\mathrm{McAb} 8$, directed against the 4I, 46 and $91 \mathrm{kDa}$ early proteins of RCMV, results in nuclear staining (8). The sections were washed and incubated with biotinylated, affinity-purified sheep anti-mouse $\operatorname{Ig}$ (Amersham Nederland B.V., Houten, The Netherlands). After washing, the sections were incubated with streptavidin-biotinylated horseradish peroxidase complex (Amersham), washed again and incubated for $10 \mathrm{~min}$. in diaminobenzidine in $0.1 \mathrm{M}$ TRIS with $0.05 \% \mathrm{H}_{2} \mathrm{O}_{2}$. Sections were counter stained with haematoxylin, dried and embedded in Entellan (30).

Membrane antigens were stained by a standard immunoperoxidase procedure on frozen sections with commercially available $\mathrm{McAb}$ against monocyte/macrophage antigens (ED1, ED2, ED3) (10) and lymphocyte antigens (W3/13) (4).

\section{Statistical analysis}

Continuous variables, such as splenic weights and the PFU counts were expressed as mean \pm standard deviation. The Students-t-test was used to calculate the statistical significance of differences in these parameters (2). Ordinal categorical data, such as infiltration scores, were expressed as median and (range). The Mann-Whitney U-Wilcoxon test ( $Z$ corrected for ties) was used to calculate significance of differences in the infiltration scores $(1,2) . P$-values $<$ 0.05 were considered to indicate statistical significance. 
Table 2. CMV-expressing cells in lungs after allogeneic lung Tx in BMT recipient rats.

\begin{tabular}{|c|c|c|c|c|}
\hline \multirow[t]{2}{*}{ Lung compantment } & \multicolumn{2}{|c|}{ Lungs group 1} & \multicolumn{2}{|c|}{ Lungs group 3} \\
\hline & recilpient & donor & recipient & donor \\
\hline $\begin{array}{l}\text { CMV antigen expresing cells: } \\
\text { intrablyolar }\end{array}$ & $3(2)$ & $1(1)^{b}$ & $2(1)$ & $0(1)^{b}$ \\
\hline intural veolar & $0(0)$ & $0(1)$ & $0(1)$ & $0(0)$ \\
\hline intravaseular & $0(1)$ & $0(1)$ & $0(0)$ & $0(0)$ \\
\hline penfivascular & $0(1)$ & $0(1)$ & $0(0)$ & $1(2)^{b}$ \\
\hline intrabronchial & $0(0)$ & $0(0)$ & $0(0)$ & $0(0)$ \\
\hline peribronchial & $0(0)$ & $0(0)$ & $0(0)$ & $0(0)$ \\
\hline pletural & $0(1)$ & $3(1)^{b}$ & $0(0)$ & $2(2)^{b ; c}$ \\
\hline
\end{tabular}

The BN rats received Le Lung Tx, TBI, RCMV and Le BMTX (group 1). Anumals from group 3 received additional Le lymphocytes at day 5 p.i.

"Cells, reactive with monoclonal antibody no 8 and 35 were scored as $0=a b s e n t, 1=$ slight infiltrate, 2 - moderate dense infiltrate, $3=$ dense in filtrate. The numbers express the median and (range).

Significanee of differences by Mann-Whitney U-Wilcoxon Rank W Sum test $(Z$ corrected for ties $)(P<0.05)$; " transplamt wersus recipient lung," group 3 versus group 1 .

\section{RESULTS}

\section{Manifestation of CMV infection}

CMV infection resulted in symptomatic disease at eight days after virus inoculation. At that day the lungs and spleen were evaluated for the presence of infectious virus and viral antigens. The effect of additional lymphocyte transfer, the presence of a syngeneic versus an allogeneic lung transplant and syngeneic versus allogeneic bone marrow transplant. The virus plaque assay revealed no significant differences of infectious virus titres in both the recipient lungs of all RCMV-infected rats $(4.57 \pm 1.14$ (mean \pm STD), $5.06 \pm 1.06,5.38 \pm 2.26$ and $4.86 \pm$ $1.87 \log _{10}$ PFU RCMV, for groups $1,3,5$ and 7 , respectively) and the donor lungs of these animals ( $4.73 \pm 1.26$ (mean \pm STD) $, 6.21 \pm 1.22,6.23 \pm 2.08$ and $5.11 \pm 2.31 \log _{10}$ PFU for groups $1,3,5$ and 7 , respectively). In addition, the number of infectious virus particles was comparable in the spleen of all the RCMV-infected animals ( $3.77 \pm 2.17$ (mean \pm STD), 4.96 $\pm 3.33,4.33 \pm 1.34$ and $4.57 \pm 1.12 \log _{10}$ PFU of RCMV for groups $1,3,5$, and 7 , respectively). These results indicate that virus titres in the spleen and lungs are not influenced by the major histocompatibility complex-1 (MHC-1) antigen type of the lung, or by the type of reconstituted bone marrow cells and transfered lymphocytes.

Immunohistochemical evaluation, however, revealed differences between BN donor and Le recipient lungs in the amount of CMV-specific antigens in different lung compartments of CMV-infected animals (group 1). As shown in table 2, the amount of CMV-antigen containing 


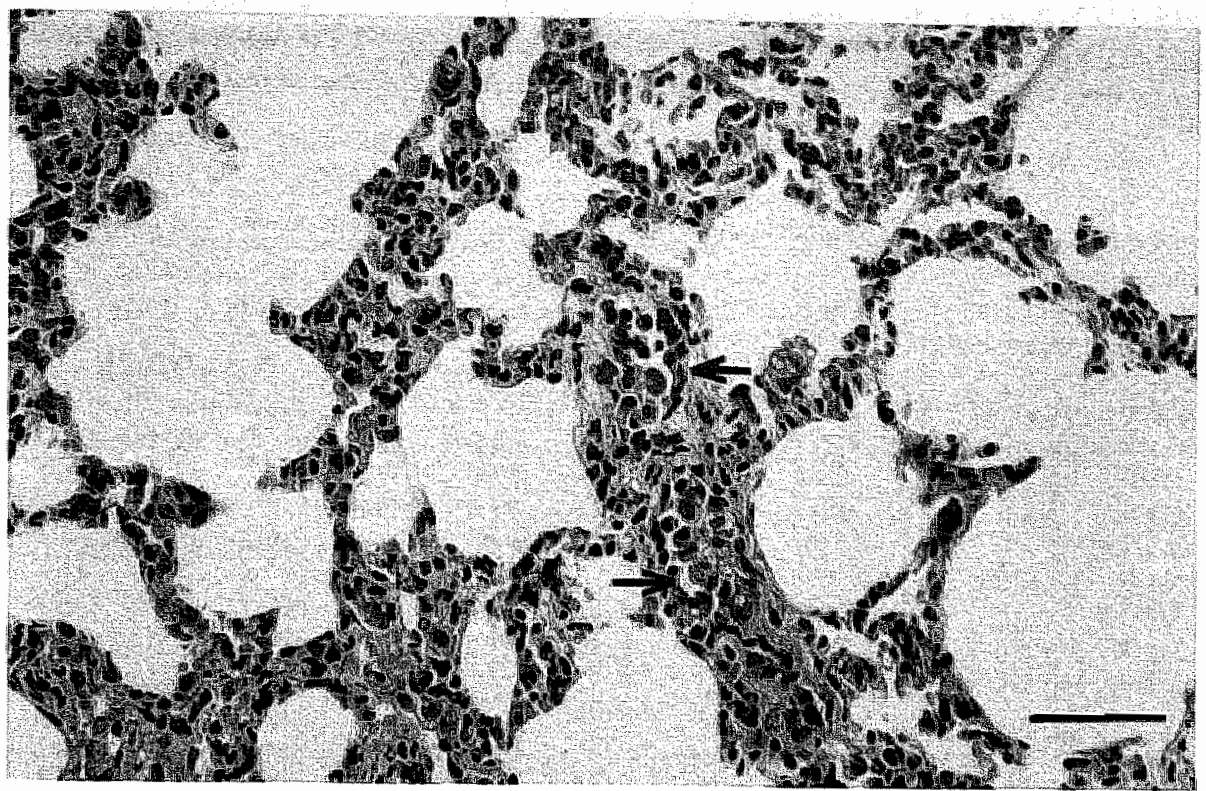

Figure 2. Haematoxylin-eosin staining of lung tissue. The antow points a longindinal presentation of a vene, showing slugging with mononuclear cells. The surrounding alveolia septa are congested, but show a relatively low cell number. Bar: $5 \mu \mathrm{m}$.

cells in the alveolar septa of the allogeneic recipient lung from these animals were more numerous than in the syngeneic (Le) donor lung $(P<0.05)$. This was also true for animals which received an additional lymphocyte transfer (group 3). In contrast, the CMV harbouring cells were more numerous in the Le donor lung in animals that received $B N$ bone marrow (group 7), than in the BN recipient lung (density scores for both lungs were 2(2) and $1(1)$, respectively). However, in BN rats that received a syngeneic (BN) donor lung (group 5) the antigen load was comparable in both the recipient and the donor lung (infiltration scores were 2 for both lungs, data not shown). These results pointed out that the CMV antigen load was higher in the alveolar septa when the lung tissue was allogeneic to the bone marrow.

The amount of CMV-reactive cells was higher in the pleura of the lung transplants than in the pleura of the recipient lung of all RCMV-infected animals (group $1,3,5$, and 7$),(P<0.05$ ). For groups 1 and 3 these data are presented in table 2. The other compartments of the lungs harboured only few CMV-reactive cells in all RCMV-infected animals.

Cells that showed specific intranuclear inclusions in the alveolar compartment were identified as type II pneumocytes, mononuclear (ED-1 reactive) inflammatory cells and endothelial cells. Cells which were localized in the pleura and which harboured eosinophilic nuclear inclusions, were identified as mononuclear (ED-1 reactive) inllammatory cells as well as mesothelial cells. 
Table 3. Panameters for interstial pnewnona eight days after alogeneic lung TX and BMTX in rats.

\begin{tabular}{|c|c|c|c|c|c|c|c|c|}
\hline \multirow{2}{*}{$\begin{array}{l}\text { Group: } \\
\text { Lung: }\end{array}$} & \multicolumn{2}{|l|}{ RCMV } & \multicolumn{2}{|l|}{$\begin{array}{l}2 \\
\text { mock }\end{array}$} & \multicolumn{2}{|c|}{$\begin{array}{l}3 \\
\text { lymphocytes } \\
+\mathrm{RCMV}\end{array}$} & \multicolumn{2}{|c|}{$\begin{array}{l}4 \\
\text { lymphochytes } \\
\text { + mock }\end{array}$} \\
\hline & \multicolumn{2}{|c|}{ recipient donor } & \multicolumn{2}{|c|}{ recipient donor } & \multicolumn{2}{|c|}{ recipient donor } & \multicolumn{2}{|c|}{ recipient donor } \\
\hline $\begin{array}{l}\text { Microvascular damage: } \\
\text { endothelial ballooning } \\
\text { loosening of endothelium }\end{array}$ & $\begin{array}{l}+ \text { (D) } \\
+ \text { (D) }\end{array}$ & $+(F)$ &. & - & $\begin{array}{l}+ \text { (D) } \\
+ \text { (D) }\end{array}$ & $\begin{array}{l}+(\mathrm{F}) \\
-\end{array}$ & - & - \\
\hline \multicolumn{9}{|l|}{$\begin{array}{l}\text { Infiltrative cell score } \\
\text { alveolar septa: }\end{array}$} \\
\hline MN & $0(1)$ & $2(1)^{c}$ & $0(0)$ & $1(1)$ & $o(0)$ & $3(1)^{c, h}$ & $1(2)$ & $3(3)^{c_{n} d}$ \\
\hline EDI & $1(1)$ & $1(1)$ & $a(0)$ & $0(1)$ & $1(0)$ & $1(0)$ & $0(0)$ & $2(1)^{6, \mathbb{d}}$ \\
\hline$W 3 / 13$ & $0(0)$ & I(1) & $0(1)$ & $0(0)$ & $1(1)$ & $1(0)$ & $1(0)$ & $1(1)$ \\
\hline \multicolumn{9}{|l|}{ alveolar spaces: } \\
\hline EDII & $0(1)$ & $1(1)$ & $0(0)$ & $1(1)$ & $1(\mathbb{1})$ & $1(\mathbb{1})$ & $0(1)$ & $2(1)^{6}$ \\
\hline $\begin{array}{l}\text { W3/13 } \\
\text { pleura: }\end{array}$ & $0(1)$ & $1(1)$ & $0(1)$ & $0(0)$ & $0(1)$ & $0(0)$ & $0(0)$ & $3(3)^{c, t, f, f}$ \\
\hline$M N$ & $0(0)$ & $2(1)^{8}$ & $0(0)$ & $1(1)$ & $2(1)$ & $3(0)$ & $2(2)$ & $3(3)^{d}$ \\
\hline EDI & $0(1)$ & $1(2)$ & $0(0)$ & $1(1)$ & $0(0)$ & $0(1)$ & $\rrbracket(1)$ & $2(1)^{d, s}$ \\
\hline$W / 13$ & $0(0)$ & $1(2)^{\operatorname{lof}_{1}, g}$ & $0(0)$ & $0(0)$ & $0(0)$ & $1(1)$ & $0(0)$ & $0(0)$ \\
\hline
\end{tabular}

The BN rats received Le lung, TBI, and Le BMTX. Groups 3 and 4 received an additional lymphocyte transfer.

"Microvascular damage was scored as absent $(-)$, present $(+)$ or severe $(++)$. The lesions were present either diffuse (D) or focal (F) in the lung tissue.

Infiltrative cells were scored as $0=$ absent, $1=$ slight infiltrate, $2=$ moderate dense infiltrate, $3=$ dense infiltrate, The values were expressed as median and (range).

Significance by Mann-Whitney U-Wilcoxon Rank W Sum Test $(P<0.05)$ : "transplant versus recipient lung, ${ }^{\circ}$ group 4 versus group $2,{ }^{\circ}$ group 4 versus group $3,{ }^{f}$ group 4 versus group $1,{ }^{g}$ group 2 wersus group 1, " group 3 versus group 1.

\section{Interstitial lung injury and interstitial inflammatory responses}

The different lung compartments were evaluated for the presence of lung injury and inflammatory responses. The recipient lungs from RCMV-infected $B N$ rats (group 1) showed adherence of ED-1 reactive (monocytic) cells at the site of capillary venules, with swelling of the endothelium and sometimes detachment of the endothelial cells from the basal layer of the capillary wall. Generally, this endothelial damage was accompanied by diffuse vascular dilatation (table 3). Capillary leakage with severe diffuse congestion of the alveolar septal wall was observed (figure 2). In contrast to the recipient lung, in the Le donor lung endothelial swelling, capillary leakage and congestion of the alveolar septal wall appeared to be localized focally. These results suggest that the extent of vascular damage was concordant with the CMV antigen load in those lungs which were allogeneic to the bone marrow (table 2). In animals that received additional lymphocytes (group 3 ) the extensive microvascular damage 
Talble 4. Parameters of graft warsus host reaction eight days after allogeneic lung $1 \mathrm{x}$ and $\mathrm{BMT}$.

\begin{tabular}{|c|c|c|c|c|c|c|c|c|}
\hline \multirow{2}{*}{$\begin{array}{l}\text { Group: } \\
\text { Lung: }\end{array}$} & \multicolumn{2}{|c|}{$\begin{array}{l}1 \\
\mathrm{RCMV}\end{array}$} & \multicolumn{2}{|l|}{$\begin{array}{l}2 \\
\text { mock }\end{array}$} & \multicolumn{2}{|c|}{$\begin{array}{l}3 \\
\text { lymphocytes } \\
+\mathrm{RCMV}\end{array}$} & \multicolumn{2}{|c|}{$\begin{array}{l}4 \\
\text { Jympliocytes } \\
\text { mock }\end{array}$} \\
\hline & \multicolumn{2}{|c|}{ recipient doner } & \multicolumn{2}{|c|}{ recipient donor } & \multicolumn{2}{|c|}{ recipient donor } & \multicolumn{2}{|c|}{ recipient donor } \\
\hline $\begin{array}{l}\text { Rejection parameters } \\
\text { Relative splentic weight }\end{array}$ & $19 \pm 0$ & & $2.1 \pm 0$. & & $1.6 \pm 0$ & & 1.740 & \\
\hline $\begin{array}{l}\text { Histopathologic score } \\
\text { perivascular infiltrates: }\end{array}$ & & & & & & & & \\
\hline $\mathrm{MN}$ & $0(0)$ & $0(0)$ & $0(0)$ & $0(0)$ & $1(1)$ & $2(1)^{\mathrm{e} d \mathrm{~d} e}$ & $1(1)$ & $3(3)^{0,4,4}$ \\
\hline EDI & $0(0)$ & (1) & $0(0)$ & $1(1)$ & $0(0)$ & $2(1)^{\varepsilon}$ & $1(1)$ & $2(1)^{\circ}$ \\
\hline $\begin{array}{l}\text { W3/13 } \\
\text { peribronchial infiltrates: }\end{array}$ & $0(0)$ & $1(1)$ & $0(0)$ & $0(1)$ & $0(0)$ & $0(0)$ & $0(1)$ & $0(0)$ \\
\hline $\mathrm{MN}$ & $a(1)$ & $0(1)$ & $0(0)$ & $0(0)$ & $0(0)$ & $0(0)$ & $0(0)$ & $1(1)$ \\
\hline EDI & $0(0)$ & $1(1)$ & $0(0)$ & $1(1)$ & $0(0)$ & $1(1)$ & $O(0)$ & $1(i)$ \\
\hline W/3/13 & $0(0)$ & $1(1)$ & $0(0)$ & $0(1)$ & $0(0)$ & $0(0)$ & $0(0)$ & $0(0)$ \\
\hline
\end{tabular}

The animals received Le lung, TBI, and Le BMTX. Groups 3 and 4 received an additional lymphocyte trans fer.

${ }^{a}$ The relative splenic weight was determined by the ratio of splenic weight (mg) and total body weight (g) at the day animals were sacrificed. Values were expressed as mean \pm STD.

Differences of splenic weight were calculated by the T-test..

${ }^{b}$ Infiltrative cells were scored as $0=$ absent, $1=$ slight infiltrate, $2=$ moderate dense infiltrate, $3=$ dense infiltrate. The values were expressed as median and (range).

Significant differences by Mam-Whitney U-Wilcoxon Rank W Sum Test $(P<0.05$ ): "transplant versus recipient lung d group 3 versus group 1, "group 3 versus group 2, "group 4 versus group 1, group 4 versus group 2 .

and accompanying diffuse congestion of the alveolar septal wall were also noticed in the recipient lung, but not in the donor lung, that only showed focal lesions. In addition, extensive microvascular damage was observed in both allogeneic lungs of animals that received a $B N$ donor lung (group 5). In rats that received a syngeneic BMTX (group 7) the RCMV-infected Le allograft showed extensive microvascular damage and severe congestion of the alveolar septa. In contrast, the recipient lung was only focally injured. In mock-infected controls (group 2, 4,6 and 9) microvascular damage was not noticed in both lungs, indicating that the microvascular damage is strictly related to CMV infection. The Le donor lung of the mock-infected controls (group 8) was completely necrotic as described below.

The inflammatory response in the alveolar septa and alveolar spaces was monitored by an inflammatory cell score (table 3). In the alveolar septal wall of RCMV-infected rats (group 1) only few infiltrating monocytic cells were present. In addition, very low numbers of alveolar macrophages were present in the alveolar spaces of these lungs (figure 2). Moderately dense infiltrates, however, were present in the alveolar septa of the donor lungs $(P<0.05)$, possibly as a result of transplant injury. In contrast, the cell density was not significantly different in both lungs of mock-infected animals (group 2). In the septal wall of the Le donor lung from 
lymphocyte recipients (group 3 and 4) the number of predominantly monocytic cells was significantly higher than in the recipient lung of these animals $(P<0.05)$. In the donor lungs of these animals the monocytic cell density was higher than in the lungs of animals, that did not receive an additional lymphocyte transfer (group 1 and 2). In the alveolar space of the donor lungs of RCMV-infected rats that did receive additional lymphocytes (group 3) an increase of predominantly lymphocytic cell density was observed. There was no difference in inflammatory response between these animals (group 3) and mock-infected (group 4) controls. In animals that received either a BN lung or BN bone marrow (groups 5, 6, 7 and 9) the alveolar septal wall was generally more densely infiltrated in the donor lung than in the recipient lung, indicating an inflammatory response to transplant injury. In group 8 the transplant lung was necrotic as described below.

In the donor lungs of all animal groups the pleural and subpleural area were densely infiltrated with mononuclear (ED-1 reactive) cells. In the pleura of the recipient lungs, however, infiltration with mononuclear cells was not observed, indicating a transplant-associated effect. The pleura of transplants from CMV-infected animals appeared to be more densely infiltrated than that of mock-infected animals. Nuclear CMV inclusions were present in many of these cells and mesothelial cell proliferation was more widespread. In non-transplanted lungs a pleural reaction was almost absent.

\section{Graft-versus-host reaction}

The relative splenic weights of normal eight-week-old BN rats ranges between 2.0 and 2.4 $\mathrm{mg} / \mathrm{g}$ (data not shown). Table 4 shows that the splenic weights of RCMV-infected as well as mock-infected allogeneic BMT recipient rats (group 1 and 2, respectively) were within the range of control values at 8 days after BMTx. Therefore, infection with RCMV seems not to induce GvHD. Generally, significant differences in the splenic weights were not observed in any of the studied animals (groups 3, 4, 5, 6 and 9, data not shown). In contrast, mock-infected animals which received a Le lung Tx and BN BMTx (group 8) presented an increased splenic weight $(2.7 \pm 1.5 \mathrm{mg} / \mathrm{g})(P<0.05)$. The relative splenic weight was considerably lower in the RCMV-infected group 7 animals $(1.5 \pm 0.4 \mathrm{mg} / \mathrm{g})$, than in the mock-infected group 8 animals $(\mathrm{P}<0.05)$, suggesting inhibition of allograft rejection by $\mathrm{CMV}$.

The amount of infiltrating ED1 and W/13 reactive cells in the perivascular and peribronchial region of both the BN recipient lung and the Le donor lung of RCMV-and mock-infected animals (group 1 and 2, respectively) was not increased. However, in the donor lung of animals which received an additional lymphocyte transfer (group 3 and 4) the amount of infiltrating mononuclear (ED 1-reactive) cells was largely increased $(P<0.05)$. In the perivascular region of the lungs from animals that received a BN donor lung (group 5 and 6) these cell densities were only slightly higher. The perivascular region of the Le donor lung from RCMV-infected BN BMT recipient rats (group 7) was infiltrated by many mononuclear cells. In addition, perivascular infiltrates were observed around the large hilar vessels of the donor lung of mock-infected rats (group 8), despite extensive necrosis of the alveolar tissue. Perivascular infiltrates were not observed in syngeneic controls (group 9). 


\section{Discussion}

In this report we describe the pathology of CMV-induced ILD in relation to GVHD, which is a major risk factor for ILD. Previously, we found that RCMV infection of allogeneic BMT recipients resulted in a generalized virus infection affecting many organs, including the lungs $(30,32)$.

Generalized RCMV infection resulted in high infectious virus titres in spleen and in lung tissue. There was no difference in infectious virus titres between the donor and recipient lung, irrespective of the type of MHC-1 class antigen of the donor lung. However, the localization of infiltrating CMV antigen-expressing cells in the lung tissue differed significantly: the recipient lung of group 1 animals, which was allogeneic to the reconstituted bone marrow cells, harboured a relatively high number of CMV antigen-expressing cells in the intra-alveolar spaces and in the septal wall. These cells were identified as monocytes, macrophages, type II pneumocytes and endothelial cells. The number of infiltrated CMV antigen-expressing cells in the alveolar septa and the number of infectious virus particles were not decreased by additional lymphocyte transfer. These findings underline that in these animals the control of CMV infection by lymphocytes is inadequate during conditions of MHC class I disparity. The enhanced expression of CMV encoded antigens in the pleura of the transplant lung, but not in the recipient lung is probably a result of transplantation injury. This is supported by the absence of pleural infection in previous allogeneic BMTx experiments without lung $T x$, in which pleural reaction and pleural CMV infection were absent (32). Transplantation injury and subsequent monocytic cell infiltration and mesotheliall cell proliferation of the pleura could lead to a local increase of viral expression, since it has been described that monocytic cells can transfer CMV to endothelial cells (35). This notion is supported by the results of spleen cell transfer experiments in mice, in which higher virus titres were observed in spleen and lungs of animals to which either allogeneic or syngeneic spleen cells were administered than in animals without cell transfer (25).

Diffuse ILD in the BN recipient lungs of RCMV-infected animals (group 1) was characterized by swelling and sometimes detachment of the capillary endothelium, increased adherence of leucocytes to the capillary endothelial layer and congestion of the alveolar wall. This extended capillary pathology in CMV-infected allogeneic lungs forms a clue to the pethogenesis of CMV-induced pulmonary disease, since in the syngeneic lung transplant, which harboured only few CMV antigen-expressing cells and in mock-infected animals capillary damage was minimal. CMV-induced endothelial injury in allograft aorta vascular wall and vascular involvement during generalized RCMV infection in rats after sublethal TBI has previously been described (15), (M. Persoons, F.S. Stals, C.A. Bruggeman, submitted for publication). Endothelial cells showed ballooning and detachment from the basallayer of the capillary wall. in addition, animals with chronic CMV infection showed ultrastructural endothelial changes (29). In vitro, infection experiments have shown that CMV induces a procoagulant activity on microvascular endothelium and results in the appearance of adhesion molecules such as ELAM and VCAM (34). In addition, clinical and experimental data have indicated a role of CMV-induced vascular injury in the inflammatory response to allograft vascular endothelium 
$(5,15,17)$. Our finding of a poor inflammatory response to $\mathrm{CMV}$ infection in the lung is in contrast with the suggestion that CMV-induced ILD is an immunopathologic process in which a local aggressive immune response during immunocompromised conditions is induced (13, 19). In contrast, endothelial injury with only minor inflammatory cell infiltration was described in human fung allografts (12), corroborating our finding that endotheliall injury is an important factor in the pathogenesis of ILD.

Additional lymphocyte transfer led to an increased monocytic cell infiltration in the alveolar septa of lungs from RCMV-infected rats from group 5 as well as mock-infected animals from group 6. Particularly, the Le lung transplant was more densely infiltrated. This is in agreement with previous studies, performed in mice, which showed that allogeneic splenocytes that induced GvHD also induce responses to CMV in the alveolar wall (13). Despite the higher number of infiltrating cells after lymphocyte transfer the virus titres were not significantly decreased in the allogeneic lung, indicating that CMV escapes from immune surveillance. In this regard, it has been described that CMV can alter lymphoid functions, such as antigenspecific mitosis, interferon production and cytotoxic T-cell induction (38).

The major characteristic for GvHD is the increase in the relative splenic weight (28). The relative splenic weight of the experimental groups 1 and 2 did not differ significantly. In addition, eight days after allogeneic BMTx, no signs of acute GvHD were observed in the lungs of RCMV-infected as well as mock-infected animals. After additional lymphocyte transfer, splenic weights were not increased. This was true for both RCMV-infected rats (group 3 and 5) and mock-infected (group 4 and 6) animals. These results are in agreement with data from mice studies, in which splenic weights after allogeneic bone marrow transplantation slightly decreased after CMV infection (25). In this study, after syngeneic BMTx the relative splenic weight was significantly higher in mock-infected animals (group 8) than in RCMV-infected rats (group 7), suggesting that a strong cellular allo-response to the lung transplant is inhibited by CMV infection. This is also supported by the finding that the mock-infected Le lung transplant showed extensive necrosis, whereas the allogeneic transplant in the RCMV-infected group was damaged to a lesser extent. The poor response of bone marrow cells to the allogeneic lung tissue in the RCMV-infected animals can be the result of inlaibited regeneration of stem cells after CMV infection in the bone marrow cavity itself. Such an inhibitory effect by CMV on stem cell proliferation has previously been described for mice (21). In addition, human stem cell proliferation was inhibited in vitro by CMV (16). The reason why in group 8 the response of the $\mathrm{BN}$ bone marrow to the Le lung is more severe than the response of the Le bone marrow to BN lungs (group 2 and 4 ) is not completely clear. The homing of both syngeneic and allogeneic T cells is qualitatively comparable at 8 days post transplantation (33). Immunologic differences between these species, however, are not excluded.

We conclude that CMV-induced ILD is a pathological process characterized by extensive microvascular damage, and that it occurs under conditions of impaired immunologic control, such as after allogeneic BMTx. In addition, lymphocytes seem to be involved only secondarily in the pathogenesis of ILD, and GvHD is not a prerequisite for induction of ILD. 


\section{References}

1. Agresti, A. 1984. Analysis of ordinal categorical data. John Wiley and sons, inc., New York. 287 pp.

2. Armitage, P., and G. Berry. 1991. Statistical methods in medical research. Blackwell Soientific Publications, London. $559 \mathrm{pp}$.

3. Bos, G. M., G. D. Majoor, C. A. Bruggeman, G. Grauls, M. J, wan-de-Gaar, and P. J. van-Breda-Vriesman. 1989. Rat cytomegalovirus can be transferred by bone marrow cells but does not affect the course of acute graft-versus-host disease. Transplant. Proc. $21: 3050-3052$.

4. Brown, W. R. A., A. N. Barelay, C. A. Sunderland, and A. F. Willams. 1981. Identification of a glycophorin-like molecule at the cell-surface of rat thymocytes. Nanture. 289:456-460.

5. Bruggeman, C. A. 1993. Cytamegalovirus and latency: an overview. Virchows. Arch. B. Cell. Pathol. 64:325-333.

6. Bruggeman, C. A., W. M. Debie, G. Grauls, G. Majoor, and C. P. van-Boven. 1983. Infection of laboratory rats with a new cytomegalo-like virus. Arch. Virol. 76:189-199.

7. Bruggeman, C. A., H. Meijer, P. H. J. Dormans, W. M. H. Debie, G. E. L. M. Grauls, and C. P. A. van Boven. 1982. Isolation of a cytomegalovirus-like agent from wild rats. Arch. Virol 73:231-241.

8. Bruning, J.H., W.H. Debie, P. H. Dormans, H. Mejjer, and C. A. Bruggeman. 1987. The development and characterization of monoclonal antibodies against rat cytomegallowirus induced antigens. Arch. Virol 94:55-70.

9. Coiffier, B., T. Philip, A. K. Bumett, and M. L. Symann. 1994. Consensus conference on intensive chemotherapy plus hematopoietic stem cell transplantation in malignancies. J. Clin. Oncol. 12:226231.

10. Dijkstra, C. D., E. A. Döpp, P. Joling, and G. Kraal. 1985. The heterogeneity of mononuclear phagocytes in lymphoid organs: distinct macrophage subpopulations in the rat recognized by monoclonal antibodies. EDI,ED2 and ED3. Immunology. 54:589-599.

11. Engvall, E., and P. Perlmann. 1972. Enzyme-linked immunosorbent assay, ELISA. J. Immunol 109:129-135.

12. Fend, F., C. Prior, R. Margreiter, and G. Mikuz. 1990. Cytomegalowirus pneumonitis in heart-lung transplant recipients: histopathology and clinicopathologic considerations. Hum. Pathol. 21:918-926.

13. Grundy, J. E, J. D. Shanley, and G. M. Shearer. 1985. Augmentation of graft-versus-host reaction by cytomegalovirus infection resulting in interstitial pneumonitis. Transplantation 39:548-553.

14. Ho, M. 1991. Cytomegalovirus. Biology and Infection. Plenum Medical Book Company, New York. 440 pp.

15. Koskinen, P. K. Lemström, C. Bruggeman, I. Látenschlager, and P. Hayry, 1994. Acute cytomegglovirus infection induces a subendothelial inflammation (endothelialitis) in the allograft vascular wall. A possible linkage with enhanced allograft arteriosclerosis. Am. J. Pathol 144:41-50.

16. Lagneaux, L., A. Delforge, R. Snoeck, P. Stryckmans, and D. Bron. 1994. Decreased production of cytokines after cytomegalovirus infection of marrow-derived stromal cells. Exp. Hematol. 22:26-30.

17. Lemstrom, K. B. J. H. Bruning, C. A. Bruggeman, I. T. Lautenschlager, and P. J. Hayry, 1993. Cytomegalovirus infection enhances smooth muscle cell proliferation and intimal thickening of rat aortic allografts. J. Clin. Invest. 92:549-558.

18. Marck, K. W., and C. R. H. Wildevuur. 1982. lung transplantation in the rat. I. Technique and survival. Ann. Thorac. Surg. 34:74-80.

19. Milburn, H. J., R. M. Du-Bois, H. G. Prentice, and L. W. Poulter. 1990. Pneumonitis in bone marrow transplant recipients results from a local immune response. Clin. Exp. Imwunol. 81:232-237.

20. Mills, J., and L. Corey. 1986. Antiviral therapy: new directions for clinical application and research. Elsevier Science Publishing, inc., New York. 195-203 pp. 
21. Mutter, W. M. J. Reddehase, F. W. Busch, H. J. Buhring, and U. H. Koszinowski. 1988. Failure in generating hemopoietic stem cells is the primary cause of death from cytomegalovinus disease in the immunacompromised host. J. Exp. Med. 167:1645-1658.

22. Prop, J. J. P. A. Wagenaar, A. H. Petersen, and C. R. H. Wildevuur. 1984. lung transplantation in the rat. In CRC Handbook of microsurgery, vol. 2. W. L. Olszewski, editors. CRC Press, Florida. $493-509$ pp.

23. Rasing, L. A, R. A, De-Weger, L. F. Verdanck, W. van-der-Bü, P. I. Compier-Spies, G. C. De-Gast, C. D. Van-Basten, and H.J. Schuurman. 1990. The value of immunohistochemistry and in situ hybridization in detecting cytomegalowirus in bone marrow transplant recipients. Apmis. 98:479-488.

24. Schwarz, M I., and T. E. King. 1993. Interstitial lung disease. Mosby year Book, London. $821 \mathrm{pp}$.

25. Shanley, J. D., R. Komgold, and S. J. Forman. 1993. The effect of graft-versus-host disease in response to minor histocompatibility antigens on acute murine cytomegalovirus infection. Transplantation 56:487-489.

26. Shanley, J. D., E. L. Pesanti, and K. M. Nugent. 1982. The pathogenesis of pneumonitis due to murine cytomegalowirus. I. Infect. Dis. 146:388-396.

27. Shanley, J. D., C. Pomeroy, C. S. Via, and O. M. Shearer. 1988. Interstitial pneumonitis during murine cytomegallowirus infection and graft-versus-host reaction: effect of ganciclovir therapy. I. Infect. Dis. 158:1391-1394.

28. Simonsen, M. 1962. Graft versus host reactions. Their natural history, and applicability as tools of research. Prog. Allergy 6:349-467.

29. Span, A. H. M., P. M. Frederik, G. Grauls, C. P. A. van Boven, and C. A. Bruggernan. 1993. CMV induced vascular injury: an electron-microscopic study in the rat. $I n$ vivo 7:567-574.

30. Stals, F. S., F. Bosman, C. P. van-Boven, and C. A. Bruggeman. 1990. An animal model for therapeutic intervention studies of CMV infection in the immunocompromised host. Arch. Virol. $114: 91-107$.

31. Stals, F. S., A. E. J. M. van-den-Bogaard, and C. A. Bruggeman. 1990. Selective bowel decontamination and the incidence of bacteraemia in irradiated and cytomegalovirus indected rats. Microecol. Ther. 20:153-156.

32. Stals, F. S., A. Zeytinoglu, M. Havenith, E. de-Clercq, and C. A. Bruggeman. 1993. Rat cytomegalovirus-induced pneumonitis after allogeneic bone marrow transplantation: effective treatment with (S)-1-(3-hydroxy-2mphosphonyl-methoxy|propyl)cytosine. Amimicrob. Agents. Chemosher. 37:218223.

33. Van-Breda-Vriesman, P. J. C., L. Swanen-Sierag, and L. F. M. Vlek. 1975. Cytotoxic and enhancing properties of early_M alloantibodies elicited by first set renal allografts. In witro and in viwo studies with rat and guinea pig complement on somatic target cells with varying antigen density. Transplanw tation 20:385-392.

34. Van-Dam-Mieras, M. C., C. A. Bruggeman, A. D. Muller, W. H. Debie, and R. F. Zwaal. 1987. Induction of endothelial cell procoagulant activity by cytomegalovirus infection. Thromb. Res. 47:69-75.

35. Waldnan, W. J., D. A. Knight, E. H. Huang, and D. D. Sedmak. 1995. Bidirectional transmission of infectious cytomegalovirus between monocytes and vascular endothelial cells: an in witro model. $d$. Infect. Dis. $171: 263-272$.

36. Winston, D. J., W. G. Ho, and R. E. Champlin. 1990. Cytomegalovirus infections after allogeneic bone marrow transplantation. Rev. Imfect. Dis. 12 (Suppl. 7):S776-\$792.

37. Yagyu, K., P. J. van-Breda-Vriesman, A. M. Duijvestijn, C. A. Bruggeman, and G. Steinhoff. 1993. Reactivation of cytomegalovirus with acute rejection and cytomegalovirus infection with obliterative bronchiolitis in rat lung allografts. Transplant. Proc. 25:1152-1154. 
Pathogenesis of CMV induced interstitial lumg disecse

38. Zaia, J. A. 1990. Viral infections associated with bone martow transplantation. Hematol. Oncol. Chn North Am. 4:603-623. 


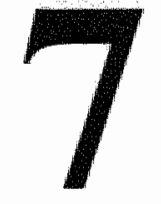

Summary and general discussion 


\section{Summary and general discussion}

Cytomegalovirus (CMV) infection is ubiquitous in man and it mostly runs an asymptomatic course in the immunocompetent host. In contrast, during immunocompromised conditions severe disease develops with high rates of morbidity and mortality. The pathogenesis of discase is poorly understood and treatment of disease is limited. Therefore, we searched for an animal model in which the pathology of CMV infection resembles that in man and which is suitable for studies on the treatment of CMV infections.

In this thesis the use of the rat is described as a host system to CMV infections in vivo. Infection of rats with a rat specific CMV (RCMV Maastricht) results in asymptomatic infection in immunocompetent rats, whereas under immunocompromised conditions severe symptoms develop. Two infection models were developed: in the first model generalized CMV infection was induced in immunocompromised rats and in the second model interstitial lung disease (ILD) was induced in allogeneic bone marrow transplant (BMT) recipient rats. In both infection models the pathogenesis of disease was studied. Additionally, the effect of different treatment modalities was studied in the two models.

For induction of generalized infection animals were immunosuppressed by a sublethal challenge ( 5 Gray) of total body irradiation (TBI) and infected with RCMV. At eight days post infection (p.i.) a generalized RCMV infection developed with macroscopic and micro scopic signs of splenitis, hepatitis and to a lesser extent pneumonia. Infection was also associated with haemostasis disorders. High virus titres were found in the spleen and Jiver and lower titres in the lung and kidney. The bone marrow was also heavily infected. Ulitimately, most animals died from infection between eight and ten days p.i. The symptoms in these animals were similar to those in patients with severe immunological impairment such as AIDS patients, in whom involvement of the bone marrow is described and in perinatally infected new-borns, which suffer from hepatitis and splenitis. Thrombocytopenia and haemostasis clisorders are also frequently described in neonates. The multiple bleedings found in the internal organs point into the direction of diffuse vascular coagulation and coagulopathy. A typical example of vascular involvement during CMV infection is CMV-induced retinitis in ALDS patients, that basically affects the vascular layer of the retina, the chorion. There is increasing evidence that $\mathrm{CMV}$-infected endothelium becomes activated and ultimately loosens from the subendothelial layer, resulting in vascular leakage and haemostatic disorders. This led to the hypothesis that changes in the vascular endothelium forms the basis of CMV-induced disease.

Pneumonia is a serious complication of CMV infection in immunocompromised patients. In particular, ILD occurs frequently in allogeneic BMT recipients. In these patients ILD is associated with CMV infection and graft versus host disease (GvHD), and is thought to be an immunopathologic process. To study the pathogenesis of CMV-induced ILD, we developed a bone marrow transplantation (BMTX) model in rats. In this model, animals received potentially lethal total body irradiation (TBI), followed by replacement of the bone marrow and CMV infection. ILD occurred in rats which had received allogeneic BMTX and RCMV infection, but not in animals which had received syngeneic BMTX and RCMV infection nor 
in mock-infected animals after allogeneic BMTX. Therefore, these studies clearly demon strated that a combination of CMV infection and allogeneic BMTX is required for the development of ILD. However, these experiments did not allow a definitive answer to the question whether the occurrence of LDD in allogeneic, but not in syngeneic BMT recipients is due to differences in the host, such as homing of the bone marrow cells, or that it is based on immunological factors, such as differences in major histocompatibility complex (MHC) antigens of the lung. Therefore, we performed a series of experiments in which prior to allogeneic BMTx, an allogeneic lung was transplanted in the host. In this model the allogeneic bone marrow recognized the donor lung as syngeneic tissue and the recipient lung as allogeneic. After RCMV infection significantly more CMV antigen-expressing cells in the interstitial septa were found in the allogeneic recipient lung than in the syngeneic donor lung. The higher viral load in the septal wall of the lung was accompanied by severe diffuse ILD, characterized by congestion of the interstitial septa with mononuclear cells and erythrocytes, swelling of endothelial cells in the pulmonary capillaries and endothelial leakage. In contrast, in the donor lung that was syngeneic to the bone marrow, only minor changes were observed in the interstitial and in the capillary endothelium. It was concluded that a high virus load in the interstitium, as is detected in the recipient lung, is associated with interstitial and endothelial changes in the capillaries and interstitial congestion. The splenic weight of these animals was not increased and an inflammatory response in the perivascular and peribronchial region of the recipient lung was absent. It was therefore concluded that these CMV-induced interstitial changes in the allogeneic lung are not associated with GwHD. In order to evoke a strong immune response, additional lymphocytes, that were syngeneic to both the bone marrow and the donor lung, were administered. After lymphocyte donation, the cellular inflammatory response in the alveolar septa of the allogeneic lung was less than in the syngeneic lung. After RCMV infection this response was not increased. Since no signs of GVHD were observed in these experiments, it can be concluded that GvHD is not a prerequisite for the development of ILD in these acutely infected rats. In this study the first particular finding was the presence of vascular leakage and subsequent congestion of the interstitial septa in the lung, that occur in the absence of an inflammatory response. These changes are related to high local virus titres after allogeneic bone marrow transplantation. Therefore, we hypothesize that vascular activation and subsequent interstitial congestion are the primary pathological findings during CMV-induced ILD. This vascular activation is followed by an inflammatory response, rather than an aggressive local immune response to CMV as suggested by others. To rule out the possibility of a fulminant local T-cell response to CMV, adoptive transfer experiments can be performed. In these experiments the effect of T-cells primed with CMV proteins can be studied on the lungs of infected allogeneic BMT recipient rats. To exclude cross reactivity between RCMV antigens and allo-antigens, these experiments can be performed in noninfected rats. The second interesting observation was the presence of CMV-induced ILD in the absence of GVHD. This finding contrasts with data from other experiments describing a statistical relation between CMV infection, ILD and GVHD. In our hands it seemed that GvHD was even inhibited by the CMV infection. An explanation for these different findings can be the relation between GWHD and reactivation of latent CMV 
infection, that confounds data in man: The combination of allogeneic transplantation and mmunosuppression evokes the reactivation of latent CMV infection. This leads to the hypothesis that GrHD and subsequent immunological cell proliferation permit the virus to reactivate from at latent state. GvHD on turn has to be treated by high level immunosuppressive regimen, making escape from immune surveillance possible. Ultimately, this results in a generalized CMV infection in which the lung is often involved. To point out the relation between $G$ WD and CMV infection, studies on latency and reactivation have to be performed. Additionally, inbred animals with only minor genetical differences in their MHC molecules can be used to elucidate the role of $M H C$ recognition with respect to CMV infection.

The second part of the study focused on the treatment of CMV disease. Two known treatment modalities are treatment with hyper immune serum (HIS) and treatment with antiviral drugs. Treatment of CMV infections with antiviral drugs, such as 9-(1,3-dihydroxy-2-propoxymethyl)guanine (DHPG or ganciclovir) is widely used. DHPG is a nucleotide analogue, that inhibits the viral DNA polymerase and that functions as a chain terminator. Treatment with DHPG seems to be effective for some patients with CMV infection, but severe adverse reactions limit the use of this drug. In particular in allogeneic BMT recipients suffering from $C M V$-induced ILD, therapy failure is described. Combination treatment of DHPG and HIS seems to be superior to treatment with either one of those.

The following questions were subject of the antiviral treatment studies in the rat model. What is the optimal therapeutic regimen and under which circumstances should combined treatment with ganciclovir and HIS be advised? Should the serum preparations used for treatment contain specific anti-CMV activity or can non-specific antibodies be used? Are there alternative antiviral agents which are effective against clinical CMV infections?

Studies were performed on HIS treatment in rats suffering from generalized RCMV infection. The HIS had high neutralizing antibody titres. The HIS administered early during infection (i.e. day 0 ) reduced mortality significantly and there was a dose effect relationship. HIS treatment reduced virus titres in many organs, such as the lungs and liver, but not in the spleen. When HIS treatment was delayed for three days it did not affect mortality and did not result in a decrease of virus titres in the internal organs. Treatment with control immune serum(CIS) had no effect on mortality, indicating that specific anti-CMV directed antibodies formed the basis of the effect on generalized CMV infection. Interestingly, variation in the virus titre in the inoculum did hardly influence the effect of HIS treatment. In contrast, increased immunosuppression from 5 to 6 Gray TBI abolished the antiviral effect of HIS. This suggests that, although antibodies against CMV act as neutralizing antibodies in vivo, cell dependent antibody actions such as antibody dependent cell toxicity may be of great importance for the recovery of virus infection. After wllogeneic $B M T x$, treatment with $\mathrm{HIS}$ had a beneficial effect on the course of CMV-induced ILD and it reduced the CMV titres in the lung. CIS had no effect on virus titres and on the development of ILD.

Studies on the effect of DHPG treatment revealed that the drug was effective against generalized RCMV infection in a dose dependent manner. The effective dose was 20 $\mathrm{mg} / \mathrm{kg} /$ day given in $\mathrm{two}$ daily doses for five days. At that dose, mortality was significantly 
reduced and the virus titres in liver and lungs were significantly decreased. Shortening of the duration of treatment and delay of treatment for three days led to therapy failure and all animals died from infection. Toxicity was not observed at that dose. DHPG treatment in the allogeneic BMTx model led to a significant decrease of virus titres in the lung of these animals, but had almost no effect on ILD.

Combined treatment with DHPG and HIS was studied in both the generalized infection model and the ILD model. In the generalized infection model, the combined treatment was synergistic, since the effective dose of both ganciclovir and HIS during combined treatment was reduced to $25 \%$ of the effective dose for treatment with a single antiviral agent. In the BMTx nodel, combined treatment with DHPG and HIS reduced the virus titres in lung and spleen to below detection levels and ILD was totally prevented. Interestingly, treatment with both DHPG and CIS reduced the virus titres in lung and spleen only slightly, but markedly reduced ILD. Administration of CIS as a single drug had no effect on virus titres and ILD.

From these experiments it can be concluded that specific antibodies to CMV have an important antiviral effect during immunocompromised conditions. Since the effect of antiviral treatment is dependent on the degree of total body irradiation, we conclude that the antiviral effect has to be supported by the cellular immune response. It would be interesting to study the activity of HIS with respect to the endothelial activation, which might be important in the pathogenesis of CMV infection. In addition, it is worthwhile to study whether CMV-induced pathology can be prevented by inhibition of endothelial cell activation.

A recently designed mucleotide analogue, (S)-1-(3-hydroxy-2-phosphonylpropoxymethyl)cytosine (HPMPC) was evaluated for the treatment of CMV infections in vivo. In vitro, HPMPC seems to be a candidate for the treatment of CMV infections, since the selectivity index (the ratio of cell toxic concentration and effective antiviral concentration) is 1400 , which is 8 times higher than that of DHPG. The drug also has some other advantages over DHPG, such as the long intracellular half life of the active metabolites and the low grade of resistance in vitro. The selectivity index of HPMPC for RCMV was about 500 . Therefore, the drug turned out to be also a selective inhibitor of RCMV infection. The in vivo antiviral activity of the drug against RCMV was assessed in the generalized infection model as well as in the ILD model. In the generalized infection model HPMPC was far more active than DHPG: the effective dose was $2 \mathrm{mg} / \mathrm{kg}$ given in a single dose as compared to DHPG, which had to be achinistered at a dose of $20 \mathrm{mg} / \mathrm{kg} /$ day twice daily for at least 5 days. One single administration of HPMPC at $20 \mathrm{mg} / \mathrm{kg}$ (which is 10 times the effective dose) completely inhibited viral replication in all organs. As was the case for DHPG, HPMPC administered as late as three days p.i. was not effective. Prewentive administration with HPMPC, in contrast to DHPG, was effective in reducing mortality from generalized infection. Toxicity was not observed at this dose. These properties of HPMPC make the drug suitable for long term preventive treatment of CMV infections. After allogeneic BMTx. HPMPC at $20 \mathrm{mg} / \mathrm{kg}$ completely inhibited viral replication in organs, such as the spleen and lungs, and the development of TLD. This study indicates that HPMPC is a potential suitable drug for the treatment of CMV infections. Applications in man have to be studied. 
Finally, the pathogenesis of RCMV infections in rats shows striking similarities with that of hunsan CMV in man, which underlines that the rat model may be important to increase the insight in the in vivo behaviour of CMV and its clinical consequences. The rat models developed in this study can also be helpful to design appropriate treatment modalities for CMV disease. However, more knowledge on the virus is necessary for detailed studies on the in vivo behaviour of CMV. 


\section{Samenvatting en algemene discussie}

Cytomegalovirus (CMV) infecties komen bij de mens algemeen voor en thet infectie beloop is meestal asymptomatisch bij mensen met een normale afweer. Onder onstandigheden, waarbij de immuniteit verminderd is, kunnen er echter ernstige infecties ontstaan, die frequent leiden tot het ontstaan van ernstige ziekte en die met een hoge mortaliteit gepaard gaan. De pathogenese van CMV infecties is grotendeels onbekend en de behandelingsmogelijkheden voor de ziekte zijn beperkt. Daarom zochten wij naar een diermodel, waarbij de pathologie van CMV infecties grote gelijkenis vertoont met die van de mens en naar een model, dat geschikt is voor het bestuderen van de behandeling van deze infecties.

In dit proefschrift wordt gebruik gemaakt van de rat als gastheer systeem voor CMV infectie. Terwijl een infectie bij immuungecompromitteerde ratten met een rat-speciffek CMV (RCMV Maastricht) meestal in een asymptomatische infectie resulteert, leidt dit in immuungecompromitteerde ratten tot ernstige symptomen. Twee infectie modellen werden ontwikkeld in de rat. In het eerste model werd een gegeneraliseerde CMV infectie geïnduceerd in immuungecompromitteerde ratten. In het tweede model werd interstitiële long ziekte (ILD) geìnduceerd door CMV infectie in ratten, die een allogene beenmerg transplantie hebben ontvangen. In beide infectie modellen werd de pathogenese van CMV-geïnduceerde ziekte onderzocht. Aansluitend werden in beide modellen diverse behandelingsstrategieën onderzocht.

Om gegeneraliseerde CMV infecties te bewerkstelligen kregen de dieren immuunsuppressie door middel van een subletale dosis ( 5 Gray) totale lichaamsbestral ing en werden ze intraperitoneaal gënfecteerd met RCMV. Op de achtste dag van de infectie ontwikkelde zich een gegeneraliseerde RCMV infectie met macroscopische en microscopische tekenen van splenitis, hepatitis en in mindere mate pneumonie. De infectie werd ook geassocicerd met bloedingsafwijkingen. Hoge virus titers werden gevonden in de milt en lever, terwijl lage titers gedetecteerd werden in de longen en nieren. Het beenmerg was ook zwaar geìnfecteerd. Uiteindelijk bezweken de meeste dieren tussen de achtste en de tiende dag van de infectie. De symptomen in deze dieren vertoonden sterke overeenkomst met symptomen, die in patiënten met ernstige immuun stoornissen worden aangetroffen, zoals patiënten met het verworven immunodeficiëntie syndroom (AIDS) en bij perinatale infecties die frequent gepaard gaan met hepatitis en splenitis, thrombocytopenie en afwijkingen in de haemostasis. De massale bloedingen aangetroffen in de interne organen wijzen in de richting van diffuse intravasale stolling met een coagulopatie. Een typisch voorbeeld van een dergelijke aandoening is đe CMV geinduceerde retinitis bij AIDS patiènten, die feitelijk een aandoening van het vaatbed van de retina, de chorion, is. Er zijn aanwijzingen dat CMV-geinfecteerd endotheel geactiveerd raakt en uiteindelijk loslaat van de subendotheliale laag, hetgeen resulteert in vaatlekkage en veranderingen in de haemostasis. Dit leidt tot de hypothese dat vaatveranderingen aan de basis kunnen staan van CMV geinduceerde ziekte.

Een ernstige complicatie van CMV infectie bij immuungecompromitteerde patienten, in het bijzonder na allogene beenmerg transplantatie (BMTx), is een interstitieel longbeeld (ILD). In deze patiënten groep wordt CMV-geïnduceerde ILD geassocieerd met graft versus host ziekte (GvHD). De pathogenese van ILD is grotendeels onbekend, maar wordt vanwege deze 
associatie als een immunopathologisch proces geduid. Om de pathogenese van CMV geinduceerde ILD te bestuderen ontwikkelden wij een BMTX model in de rat. In dit model kregen de dieren een potentieel letale dosis totale lichaamsbestraling, gevolg door terugplaatsing van beenmergcellen en CMV infectie. ILD kwam voor bij de ratten die zowel een allogene BMTX hadden gekregen en ook met CMV besmet waren, maar niet bij ratten die allén een allogene BMTX hadden gekregen en ook niet bij ratten die een syngene BMTx gekregen hadden in combinatie met CMV infectie. Uit deze gegevens blijkt duidelijk dat de combinatie van allogene BMTx en CMV infectie nodig is voor het tot stand komen van ILD. De vraag of het voorkomen van CMV geinduceerde ILD alleen na allogene BMTx, maar niet na syngene $B M T x$, te wijten is aan verschillen in de gastheer, b.v. de nesteling van de nieuwe beenmerg cellen, of dat het verschil gebaseerd is op immunollogische factoren, zoals het verschil tussen het weefseltype (MHC) wan de long en de beenmergcellen, kan uit deze experimenten echter niet beantwoord worden. Derhalve werd een reeks experimenten verricht, waarin voorafgaand aan de allogene BMTx, in de gastheer eem allogene long werd getransplanteerd. Dientengevolge wordt de donorlong door het allogene beenmerg als syngeen herkend, en de long van de ontvanger als allogeen. Met deze experimenten kon worden aangetoond, dat de allogene long van de ontwanger significant meer CMV antigeen-bevattende cellen in het interstitium bevatte, dan in de voor het beenmerg syngene long. De grote hoeveelheid geinfecteerde cellen in de alveolaire septa van de allogene long ging vergezeld met een ernstige diffuus verspreide ILD, die gekenmerkt werd door congestie van de interstitiele tussenschotten met mononucleaire cellen en erytrocyten, zwelling van het endotheel in de longcapillairen en lekkages van het endotheel. In de voor het beenmerg syngene long werden echter weinig veranderingen geobserveerd. Omdat er geen toename werd gevonden in het miltgewicht en er geen verhoogde mate van ontstekingsreaktie waar genomen werd in de perivasculaire en peribronchiale regio werden deze interstitięle veranderingen in de allogene long niet in verband gebracht met het optreden van GVHD. Om een sterke immuunrespons op te wekken werden, additioneel aan de BMTx, lymfocyten toegediend, die voor het beenmerg en de donor long syngeen waren. Na deze extra toediening van lymfocyten was de immunnrespons in de alveolaire septa van de allogene long minder dan in de syngene long. Na RCMV infectie nam deze immuunrespons niet toe. Omdat in deze experimenten geen tekenen van GVHD werden gezien, kan worden geconcludeerd dat GvHD geen voonwaarde is voor het tot stand komen van ILD in deze RCMV geinfecteerde ratten. De waatlekkage en de daaropvolgende congestie van de alveolaire septa in de long, in afwezigheid van een inflammatoire respons, is de eerste bijzondere vinding. Deze veranderingen worden geassocieerd met hoge lokale virus titers na allogene BMTX. Daarom is de hypothese ontstaan dat i.p.v. een agressieve lokale immuunrespons, de inflammatoire respons secundair is aan de vaatafwijkingen en de daaropvolgende schacle. Om de mogellikheid van een lokale fuilminante immutunrespons te onderzoeken kunnen transfer experimenten verricht worden. Daarbij kan het effect wan voor CMV gesensibiliseerde T-cellen op de long van CMV geinfecteerde ontwangers van een allogene beenmerg transplantatie onderzocht worden. Om eventuele kruisreactio tussen CMV antigenen en allo-antigenen te onderzoeken kunnen gesensibiliseerde T-cellen aan niet geïnfecteerde dieren gegeven worden. De tweede interessante 
bevinding is, in afwijking van de statistische relatie tussen CMV infectie ILD en GWHD bij de mens, het ontstaan van ILD in afwezigheid van GVHD. In onze experimenten lijkt het er zelfs op dat GVHD geremd wordt door de CMV infectie. Deze tegenstelling kan verklaart worden uit de relatie tussen GvHD en reactivatie van CMV vanuit een latente stat: Het is bekend dat de combinatie van allogene transplantatie en immunsuppressie een reactivatie van een latente CMV infectie uitlokken. Dit leidt tot de aanname dat GVHD en de daarop volgende celproliferatie reactivatie vanuit latentie toestaan. Op haar beurt wordt GVHD behandeld met hoge doses immuunsuppressiva, waardoor ontsnapping uit de immunologische controle mogelijk wordt. Dit leidt tot een gegeneraliseerde CMV infectie, waarbij de long vaak betrokken is. Om de relatie tussen GvHD en CMV infectie verder te bestuderen, moeten studies naar Jatentie en reactivatie ondernomen worden. Aansluitend kunnen studies gedaan worden, waarbij ratten met kleine genetische verschillen in hun MHC molecule gebruikt worden, teneinde de rol van de MHC gerestricteerde herkenning met betrekking tot CMV infecties te ontrafelen.

Het tweede deel van het proefschrift gaat over de behandeling van CMV infecties. Bij de mens bekende behandelingsmodaliteiten zijn behandeling met hyperimmun serum (HIS) en antivirale chemotherapie. Het meest frequent gebruikte antivirale middel is 9-(1,3-dihydroxy2-propoxymethyl)guanine (DHPG ofwel ganciclovir). DHPG is een nucleoside analoog, dat het viraal DNA polymerase remt en dat werkt door de verlenging van de DNA keten te beëindigen. Behandeling met DHPG lijkt effectief te zijn bij bepaalde groepen van patiënten met een CMV infectie, maar ernstige bijwerkingen beperken de bruikbaarheid van dit geneesmiddel. Therapeutisch falen is beschreven bij patiēnten, die lijden aan een CMV geïnduceerde ILD na het krijgen van een allogene BMTx. Combinatie therapie met DHPG en MS lijkt betere effecten te geven dan behandeling met één enkel middel.

De volgende vragen zijn onderwerp van studie in het rat model. Welke is de beste behandelingsstrategie is en wanneer moet combinatie therapie met ganciclovir en HIS gebruikt worden. Moet het gebruikte serum specifieke antilichamen tegen CMV moet bevatten, of kunnen niet-specifieke antilichaam preparaten gebruikt worden? Zijn er alternatieve antivirale middelen voor de behandeling van CMV infecties?

Bestudeerd werd de behandeling van ratten met een gegeneraliseerde RCMV infectie, met HIS. Dit HIS bevatte hoge titers aan neutraliserende antilichamen. De toediening van HIS onmiddellijk na de infectie deed de mortaliteit significant afinemen en er was een dosis-effect relatie waarneembaar. Bovendien waren de virustiters na behandeling met HIS lager in verschillende organen, zoals de longen en de lever. Indien de behandeling met HIS echter met 3 dagen werd vertraagd, was er geen effect op de mortaliteit meer waar te nemen en werd er geen afname meer van de virustiters in de inwendige organen gevonden. Behandeling met controle immuun serum (CIS) had geen effect op de mortaliteit. Dit betekent dat specifiek tegen CMV-gerichte antilichamen de basis vormden voor het antivirale effect van HIS. Interessant was ook de warmeming dat het resultaat van de behandeling met HIS nauwelijks beïnvloed werd door variatie van de hoeveelheid infectieus virus in het inoculum. Een verhoging wan de hoeveelheid totale lichaamsbestraling van 5 Gray tot 6 Gray deed de 
antiwirale werking wan HS echter volledig teniet. Dit suggereert dat, hoewel antilichamen gericht tegen CMV neutraliserend werken, cel-afhankelijke werking van antilichamen, zoals antilichaam afhankelijke cytotoxiciteit, een belangrijke rol spelen voor de herkenning van een virus infectic in vivo. Ook bij een allogene BMTX had de behandeling met HIS een gunstig effect op het beloop wan CMV geínduceerde ILD en werden de virustiters in de long verminderd. CIS had geen effect op de hoogte van de virustiters en op de ontwikkeling van ILD.

Studies nat het effect van DHPG toonden aan dat het middel effectief was voor de behandeling wan gegeneraliseerde RCMV infectie op een dosis afhankelijke wijze. De effectieve dosis was $20 \mathrm{mg} / \mathrm{kg} / \mathrm{dag}$, gegeven in twee doses per dag gedurende 5 dagen. Bij deze dosering werd de mortaliteit significant verminderd en waren de virustiters in de lever en longen significant lager. Het verkorten van de behandelingsduur, of het met drie dagen uitstel len van de behandeling, leidde tot het falen van de therapie, met als resultaat dat alle dieren overleden ten gevolge van de infectie. Toxiciteit werd niet waargenomen bij de gebruikte doseringen.

In het allogene BMTx model leidde de behandeling met DHPG tot een significante afname van de virustiters in de longen, maar het effect op ILD was gering.

Gecombinearde behandeling met DHPG en HIS werd bestudeerd in zowel het gegeneraliseerde infectie model, als in het BMTX model. In het gegeneraliseerde infectie model had de combinatie van beide middelen een synergistische werking, daar de effectieve dosis van beide middelen gedurende de gecombineerde behandeling werd verminderd tot $25 \%$ van de effectieve dosis voor de behandeling met beide middelen afzonderlijk. In het BMTx model werden met combinatie therapie de virustiters in de millt en longen tot onder het detectie niveau gebracht en het optreden van ILD werd totaal voorkomen. Het was interessant te zien dat de combinatie van DHPG en CIS de virus titers in de milt en longen maar weinig beïnvloedde, maar dat de $\mathbb{L}$ LD aanmerkelijk verminderd was. Enkelvoudige behandeling met CIS had geen effect op de virus titers en het ontstaan van ILD.

Uit deze studies kan afgeleid worden dat specifieke antilichamen, gericht tegen $\mathrm{CMV}$,

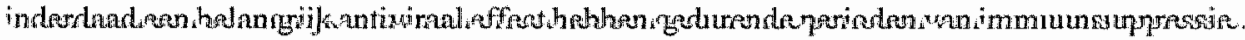
Daar de dosis van totale lichaamsbestraling van invloed is op het effect van behandeling, wordt geconcludeerd dat het antiviraal effect ondersteund moet worden door de cellulaire inmuniteit. Met betrekking tot endotheelactivatie, waarvan wij verondersteld hebben dat het van belang is de pathogenese van CMV infectie, is het interessant om de activiteit van HIIS te bestuderen. Verder is het van belang om de inwloed van endotheelactivatie remmers te bestuderen.

Ten slotte werd een recent ontwikkelde nucleotide analoog, (\$)-1-(3-hydroxy-2-phosphonyl)eytosine (HPMPC) voor de behandeling van CMV geëvalueerd. Uit in vitro gegevens bleek al, dat HPMPC een uitstekende kandidaat is voor de behandeling van CMV infecties, daar de selectiviteitsindex (de ratio van de cel-toxische concentratie en de effectieve antivirale concentratie) 1400 is, hetgeen acht maal groter is dan die van DHPG. Het middel heeft ook andere voordelen boven DHPG, zoals de lange intracellulaire halfwaardetijd van de actieve metabolieten en de geringe mate van resistentie vorming in vitro. De selectiviteitsindex van 
HPMPC voor RCMV was ongeveer 500 , hetgeen aangeef, dat het middel ook een selectieve remmer is voor RCMV replicatie. Ook werd de antivirale activiteit van het middel in vivo onderzocht; dit gebernde in beide infectiemodellen. In het gegeneraliseerde infectiemodel werd gevonden, dat HPMPC veel actiever was dan DHPG: de effectieve dosis was 2 mg/kg voor HPMPC, in een eenmalige toediening, terwijl DHPG, met een dosering van 20 $\mathrm{mg} / \mathrm{kg} / \mathrm{dag}$ verdeeld over twee dagelijkse dosis, gedurende 5 dagen moest worden toegediend. Een enkele dosis van $20 \mathrm{mg} / \mathrm{kg}$ HPMPC remde compleet de virale replicatie in alle organen. Zoals het geval was woor DHPG, was ook de behandeling met HPMPC op de derde dag na infectie niet effectief. In tegenstelling tot $\mathrm{DHPG}$, was de preventieve behandeling met HPMPC echter wel effectief en was in staat om sterfte ten gevolge van gegeneraliseerde infectie te voorkomen. Toxiciteit werd niet waargenomen, ondanks de hoge doseringen. De eigenschappen van HPMPC maken het geschikt voor langdurige profylaxe van $\mathrm{CMV}$ infecties.

Na allogene BMTX remde HPMPC bij een dosis van $20 \mathrm{mg} / \mathrm{kg}$ de virale replicatie in organen, zoals de milt en longen volledig, en remde het de ontwikkeling van ILD. Uit de resultaten van dit onderzoek kan geconcludeerd worden, dat HPMPC een geschikt middel lijkt te zijn woor de behandeling van CMV infecties.

Tenslotte toont de pathogenese van RCMV infecties in de rat opvallende overeenkomst net die van humaan CMV bij de mens, hetgeen onderstreept dat het ratmodel geschikt is voor het verkrijgen van meer inzicht in het in vivo gedrag van CMV en de klinische consequenties daarvan. De hier ontwikkelde rat modellen kunnen ook een ondersteunende rol verwullen bij het ontwikkelen van geschikte behandelingsmodaliteiten woor CMV ziekte. Om dit te bereiken is echter meer kennis nodig over het virus, zodat meer gedetailleerde studies naar het in vivo gedrag van CMV verricht kan worden. 


\section{List of publications for this thesis}

Stals, F. S., F. Bosman, C. P. wan-Boven, and C. A. Bruggenan. 1990. An animal model for therapeutio intervention studies of CMV infection in the immunocompromised laost. Arch. Virol. 114:91-107.

Stals, F. S., A. E. J. M. van-den-Bogaard, and C. A. Bruggeman. 1990. Selective bowel decontamination and the incidence of bacteraemia in irradiated and cytomegalovirus-infected rats. Microecol. Ther. 20:153156.

Stals, F. S., E. de-Clereq, and C. A. Bruggeman. 1991. Comparative activity of (S)-1-(3-hydroxy-2-phosphony/methoxypropyl)cytosine and 9-(1,3-dihydroxy-2-propoxymethyl)guanine against rat cylomegalovirus infection in vitro and in vivo. Antimicrob. Agents. Chemother. 35:2262-2266.

Stals, F. S., E. de-Clerq, and C.A. Bruggeman. 1991. Activity of (S)-1-(3-Hydroxy-2-Phosphonylmethoxypropyl)-Cytosine (HPMPC) against Rat Cytomegalowirus (RCMV) Infection in Cell Culture and in Immunocompromised Rats. In . Progress in Cytomegalovirus Research pp. 349-352. M.P. Landini, ed. Exerpta Medica, New York.

Neyts, J., F.S. Stals, S. Atherton, M. Persoons, C.A. Bruggeman and E. De Clerco. 1993. Efficacy of HPMPC in the treatment of CMV infections in various animal models. In: Multidisciplinary approach to understanding cytomegalovirus disease. pp. 279-285. S. Michelson and S.A. Plotkin, eds. Elsevier Science Publishers B.V., Amsterdam, New york.

Stals, F.S., A. Zeytinoglu, M. Havenith, E. de-Clercq, and C.A. Bruggeman. 1993. Comparative effect of (S)-1-(3-Hydroxy-2-Phosphony methoxypropyl)Cytosine (HPMPC) and 9-(1,3-Dihydroxy-2-Propxoymethyl)Guanine (DHPG) treatment on Cytomegallovirus induced interstifial pneumonia in allogeneic bone marrow transplant recipients. Transplant. Proc. 25: 1248-1249.

Stals, F. S., A. Zeytinoglu, M. Havenith, E. de-Clercq, and C. A. Bruggeman. 1993. Rat cytomegalovirusinduced pneumonitis after allogeneic bone marrow transplantation: effective treatment with (S)-1-(3-hydroxy-2-phosphonyl-methoxypropyl)eytosine. Antimicrob. Agents. Chemoiher. 37:218-223.

Stals, F. S., A. E. J. M. van-den-Bogaard, and C. A. Bruggeman. 1994. Prevention of bacteraemia by systemic ciprofloxacin treatment in rat cytomegalovirus-infected immunocompromised rats. $J$. Antimicrob. Chemother. 34:101-110.

Stals, F. S., S. S. Wagenaar, and C. A. Bruggeman. 1994. Generalized cytomegalowirus (CMV) infection and CMV-induced pneumonitis in the rat: combined effect of 9 -(1,3-dihydroxy-2-propoxymethyl)guatuine and specific antibody treatment. Anriviral. Res. 25:147-160.

The development of CMV-induced interstitia! pneumonia in the rat is lymphocyte mediated and independent of acute graft versus host response. Scand. J. lofect. Dis. In Press.

Stals, F.S., S. Sc., Wagenaar, J.S. K.loover, W.Y.R. Vanagt, C.A. Bruggeman. 1995. Combinations of ganciclovir and antibody for CMV infections. Antiviral research. In Press.

Stals, F.S., G. Steinhof, S. S. Wagenaar, P.J.P. van-Breda Vriesman., A. Hatverich, P. Dormans, F. Moeller, $C$.A. Bruggeman. Cytomegalovirus induces interstitial lung disease in allogeneic bone marrow transplant recipient rats independent of acute graft versus host response. Lab. Invest. Accepted for publication with revision. 


\section{List of additional publications}

Stals, F. $\$$., F.J. Walther, C.A. Bruggeman. 1984. Faecal and pharyngeal sthedding of rotavirus and rotavirus $\operatorname{IgA}$ in children with diarrhoev. J. Med Virol. 14:333-9.

Warnaar, A., G. Snoep and F.S. Stals. 1989. A swollen cheek, an unusual course of acute mastoiditis. Int. J. Pediatr. Ororhinollaryngol. 17:179-83.

Neyts, J, F.S. Stals, C. Bruggeman, and E. de Clercq. 1993. Activity of the anti-HIV agent 9-(2-Phosphony imethoxyethyl)-2,6-Diaminopurine against Cytomegalovirus in vitro and in viwo. Eur. $J$. Clin. Microbiol Infect. Dis. 12:437 446 .

Kraat, Y.J., F.S. Stals, M.P. Landini, and C.A. Bruggeman. 1993. Cytomegalovirus IgM antibody detection: comparison of five assays. Microbiologica. 16:297-308.

Dabekausen, Y.A.J.M., J.L.H. Evers, J.A. Land, and F.S. Stals. 1994. Chlamydia trachomatis antibody testing is more accurate than hysterosalpingography in predicting tubal factor infertility. Infertit. Steril. $61: 833-837$.

Haagmans, B.L., P.H. van der Meide, F.S. Stals, A.J.M Eertwegl, E Claassen, C.A. Bruggeman, M.C. Horzinek, and V.E.C.J. Schijns. 1994. Suppression of rat cytomegalovirus replication by antibodies against gamma interferon. J. Wirol. 68:2305-2312.

Haagmans, B.L., F.S. Stals, P.H. van der Meide, C.A. Bruggeman, M.C. Horzinek, and V.E.C.J. Schijns. 1994. Tumor mecrosis factor alpha promotes replication and pathogenicity of rat cytomegalovirus. J. Virol. 68:2297-2304.

Bruning, H., M. Persoons, K. Lemström, F.S. Stals, E. de Clercq, and C.A. Bruggeman. 1994. Enhancement of transplantation-associated atherosclerosis by $\mathrm{CMV}$, which can be prewented by antiwiral therapy in the form of HPMPC. Transpl. Int. 7 s1:s365-s370.

Lijnschoten v., G., F.S. Stals, J.L.H. Evers, C.A. Bruggeman, M.H. Havenith, J.P.M. Geraedts. 1994. The presence of cytomegalovirus antigens in karyotyped abortions. Am. J. Reprol Immunol. 32:211-220.

Brtggeman, C.A., F. Li, and F.S. Stals. 1995. The pathogenicity of CMV infection: The role of animal models. Scand. J. Infect. Dis. In press.

Steinhoff, G., X.M. You, C. Steinmüller, K. Boeke, F.S. Stals "C.A. Bruggeman, and A. Haverich. 1995. Induction of endothelial adhesion molecules by rat Cytomegalovirus (CMV) in allogeneic lung transplantation in the rat. Scand. J. Infect bis. In press. 


\section{Dankwoord}

Het schrijven van een dankwoord in een proefschrift is een uiting van erkentelijkheid voor een symbiotische samenwerkingsvorm, die in een universitaire gemeenschap en in het bijzonder in een vakgroep, gebruikelijk is. Tevens voel ik mij ingebed in een voortreffelijk gezins-, familie- en sociaal milieu, waaruit ik de nodige energie kan genereren om in genoemde symbiose te participeren.

Allereerst wil ik mijn promotores Prof. dr. C.A. Bruggeman en Prof. dr. C.P.A. van Boven oprecht danken, ondat ze mij de mogelijkheid hebben geboden om dit onderzoek te starten. Beste Catrien, ik wil jou bedanken voor je creatieve en volhardende ondersteuning en voor de vrijheid die je mij gaf bij het doorvoeren van dit onderzoek. Bij problemen of moeilijkheden kwamen wij er altijd weer uit volgens het model van these, anti-these en synthese. Jouw menselijke manier wan benaderen heb ik zeer gewaardeerd. Beste Cees, voor wat betreft de opleiding tot medisch microbioloog heb ik veel van jou geleerd. Bij het promotie-onderzoek. heb jij Catrien en mij gesteund met waardevolle vragen en suggesties.

Tot zover heb ik het gehad over de samenleving boven het oppervlak. Een overgrote hoeveelheid energie bevind zich onder het oppervlak, geleverd door meerdere mensen binnen een team met wisselende samenstelling. Ik heb het genoegen mogen smaken deze energie te bundelen en wil ieder afzonderlijk een woord van dank geven.

Wil Mullers, dank zij jouw inspanningen heeft dit proefschrift een statistisch verantwoord karakter gekregen. De vormgeving is traai en deskundig verzorgd dank zij jou.

Gert Grauls, van jou heb ik de eerste wijze lessen gehad over het werken met knaagdieren en het trotseren van primaire angsten tijdens de confrontatie met deze species. Jouw systematische wijze van werken en vastleggen van resultaten waren voor mij, zeker in de beginperiode, onontbeerlijk.

Fia Claus, bij het afleveren van mijn eerste artikelen heb jij van mijn spijkerschrift een leesbear en overzichtelijk document weten te maken. Jouw optimisme samen met je schaterlach werken aanstekelijk voor een hele afdeling.

Selma Herngreen, wij hebben samen een behoorlijke reeks experimenten verricht, die zeer goed en zorgvuldig door jou werden uitgevoerd en uitstekend gedocumenteerd. Het was je nooit teveel om extra werk te verrichten.

Peter Dormans, samen met jou heb ik de laatste series experimenten gedaan. De voorbereiding en uitvoering ervan waren keurig verzorgd. Ook tijdens de afwerkingsfase bleef jij altijd kritisch.

Martine Hulsbosch, bedankt voor jouw waardevolle ondersteuning tijdens de eindsprint. Aysin Zeytunoglu, gedurende onze gezamenlijke inspanningen betreffende de eerste beenmergtransplantaties en het ontwikkelen van een gestandaardiseerd model, heb ik jou leren waarderen als een uiterst waardevolle en hartelijke persoonlijkheid. In een jaar tijd heb jij bij iedereen binnen onze afdeling een blijvende positieve herinnering achtergelaten. 
Naast de micro-omgeving van onze vakgroep waren nog talrijke andere energiebronnen voorhanden:

Ton van de Bogaard, ik wil je bedanken voor de vele inhoudelijke discussies en praktische wenken gedlurende het verrichten van dit praktisch moeilijk uitvoerbare onderzoek.

De medewerkers wan de centrale proeldiervoorzieningen, met name Eep van Dam, Peter Kelderman en Frans Weekers wil ik graag danken woor hun deskundige medewerking en hun inspanningen om te voorzien in onze "korte termijn" bestellingen.

Prof. dr. F. Bosman, ik heb veel geleerd van je schrijfstijl en jouw snelle en deskundige manier van werken.

Dr. M. Havenith ik wil je danken voor de vele histologische beoordelingen, die jij verricht hebt met cen enorm geduld en met uiterste precisie en zorgvuldigheid.

Prof. dr. Sj. Sc. Wagenaar, jij hebt een ongelooflijk kluwen van histologische gegevens weten te ontwarren tot eenvoudige gegevens. Het was een plezier om met je samen te werken.

Prof. dr. P. van Breda Vriesman, jouw immunologisch inzicht was onontheerlijk voor het verrichten van onze laatste experimenten en het tot standkomen van het zesde hoofdstuk.

Prof. dr. E. de Clercq, jouw schijnbaar gemak van schrijven en de helderheid van analyse met betrekking tot antivirale therapie hebben een grote bijdrage geleverd voor het tot stand komen van dit proefschrift.

Dr. J. Neijts, hartelijk dank voor onze vruchtbare samenwerking en jouw ongematigd enthousiasme.

Dr. G. Steinhof, jouw voortdurend geduld en doorzettingsvermogen, gecombineerd met jouw prettige omgangsvormen, vormden de basis voor het tot standkomen van hoofdstuk 6 .

De medewerkers uit Kiel, in het bijzonder Katrien Boeke en Frank Möller wil ik danken voor het uitvoeren van de longtransplantaties.

Hiermee ben ik toegekomen aan belangrijke externe energieleveranciers, mijn kennissen, familie en mijn gezin, zonder wie het proefschrift wellicht eerder, maar waarschijnlijk prematuur tot stand gekomen was.

Lieve Mariëtte, bedankt voor jouw steun in de achterhoede en de bijna grenzeloze liefde en begrip. Lieve Kelly, Jeroen en Martijn, fijn dat jullie erbij konden zijn. 


\section{Curriculum vitae}

De auteur van dit proefschrift werd geboren op 1 februari 1959 te Winnandsrade.

Na het behalen van zijn HAVO-5 diploma aan het Bernardinus college te Heerlen volgde hij de Hoger Beroeps Opleiding (HBO) A, klinische chemie aan de Zuidlimburgse Laboratoriumschool te Sittard en de HBO-B opleiding biochemie aan het Instituut voor Hogere Beroepsopleiding te Eindhoven.

Van 1979-1980 was hij tevens werkzaam als analist op afdeling medische microbiologie aan de Rijksuniversiteit Limburg (RL) te Maastricht.

In 1980 begon hij met de studie geneeskunde aan dezelfde instelling en hij behaalde in 1986 de artsenbul. Van 1987-1991 volgde hij de opleiding tot medisch microbioloog in het Academisch Ziekenhuis Maastricht bij Prof. dr. C.P.A. van Boven. In het laatste jaar van zijn studie startte hij met het onderzoek naar de pathogenese en behandeling van cytomegalovirus infecties in de rat, hetgeen leidde tot het schrijven van dit proefschrift.

Vanaf 1991 is hij ingeschreven in het Nederlands Specialisten Register en is hij werkzaam als medisch microbioloog in het Academisch Ziekenhuis te Maastricht. 